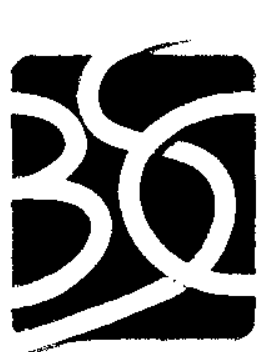

\author{
QA: QA \\ ANL-MGR-MD-000005 REV 03
}

September 2004

BECHTEL

SAIC companivuc

\title{
Characteristics of the Receptor for the Biosphere Model
}

Prepared for:

U.S. Department of Energy

Office of Civilian Radioactive Waste Management

Office of Repository Development

1551 Hillshire Drive

Las Vegas, Nevada 89134-6321

Prepared by:

Bechtel SAIC Company, LLC

1180 Town Center Drive

Las Vegas, Nevada 89144

Under Contract Number

DE-AC28-01RW12101 


\section{DISCLAIMER}

This report was prepared as an account of work sponsored by an agency of the United States Government. Neither the United States Government nor any agency thereof, nor any of their employees, nor any of their contractors, subcontractors or their employees, makes any warranty, express or implied, or assumes any legal liability or responsibility for the accuracy, completeness, or any third party's use or the results of such use of any information, apparatus, product, or process disclosed, or represents that its use would not infringe privately owned rights. Reference herein to any specific commercial product, process, or service by trade name, trademark, manufacturer, or otherwise, does not necessarily constitute or imply its endorsement, recommendation, or favoring by the United States Government or any agency thereof or its contractors or subcontractors. The views and opinions of authors expressed herein do not necessarily state or reflect those of the United States Government or any agency thereof. 
QA: QA

Characteristics of the Receptor for the Biosphere Model ANL-MGR-MD-000005 REV 03

September 2004 


\begin{tabular}{|l|l|l|}
\hline \multirow{2}{*}{ OCRWM } & Scientific Analysis Signature Page/ Change History & Page iii \\
\cline { 3 - 3 } & & 1. Total Pages: 148 \\
\hline
\end{tabular}

\section{Scientific Analysis Title \\ Characteristics of the Receptor for the Biosphere Model}

3. DI (including Revision Number)

ANL-MGR-MD-000005 REV 03

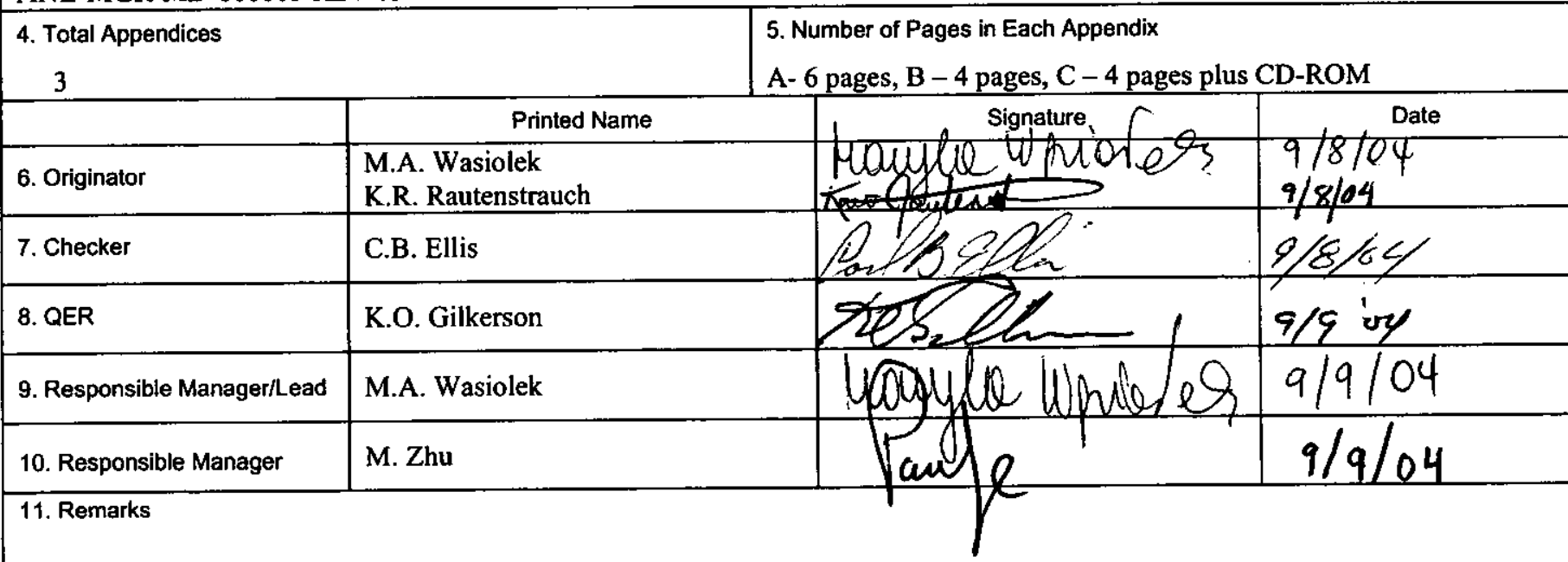

\section{Change History}

\begin{tabular}{|l|l|}
\hline 12. Revision/ICN No. & 13. Description of Change \\
\hline REV 00 ICN 00 & Initial Issue \\
\hline REV 01 ICN 00 & $\begin{array}{l}\text { Revised to adopt change in approach from "logic-based" identification of the critical group to "dose- } \\
\text { based" identification of the critical group. Added assumptions and data for time spent outdoors due to } \\
\text { employment and recreation. Developed and used radionuclide-specific behavioral factors expressed } \\
\text { in total effective dose equivalent per unit activity (rem/year per pCi/L) to distinguish between } \\
\text { combinations of behaviors and to identify the critical group. }\end{array}$ \\
\hline
\end{tabular}




\section{Scientific Analysis Signature Page/ Change History (Continued)}

\begin{tabular}{|c|c|}
\hline REV 01 ICN 01 & $\begin{array}{l}\text { Revised to remove To Be Verified (TBVs) numbered 4636, 3958, and } 4654 \text { from the Document Input } \\
\text { Reference System (DIRS) report assigned Data Tracking Numbers (DTNs) } \\
\text {...MO9806MWDGENII.000, MO0002RIB00068, MO0004ROB00085, MO0010SPAPET07.004.- } \\
\text { Identify the technical work plan (TWP) this ICN is initiated under Section 1. } \\
\text { - Remove sentence from Section } 4.1 \text { regarding survey data. } \\
\text { - Remove DTN MO9806MWDGENII.000 from Tables } 2 \text { and I-1. Identify DTN } \\
\text { MO9806MWDGENII.000 as an assumption in Section } 5.4 \\
\text { - Remove URNs where applicable in Section 8. } \\
\text { - Remove reference to "Plan for Qualification of Unqualified Data" from 1997 Biosphere Food } \\
\text { Consumption Survey. } \\
\text { - Update accession numbers in Section 8, where previously missing. } \\
\text { - Update DTNs MO0002RIB00068.000, MO0004RIB00085 to Qualified Data and } \\
\text { MO0010SPAPET07.004 to Technical Product Output in the DIRS report. } \\
\text { - Changes are indicated by change bars. } \\
\text { - The following pages were affected by this ICN 1-2, 9-10, 12-13, 15, 18, 21, 24-26, 28, 30, 32-33, } \\
\text { 36-38, 40, 53-58, I-1, I-2, I-4, I-5. } \\
\text { - Sections affected, 1.0, 2.0, 3.0, 4.0, 5.0, 6.0, 7.0, and 8.0. } \\
\text { - Software routines were not developed for this model and hence, software routine data were not } \\
\text { developed or modified as a part of this ICN }\end{array}$ \\
\hline REV 02 ICN 00 & $\begin{array}{l}\text { Revised to change the receptor from an average member of the critical group to the reasonably } \\
\text { maximally exposed individual (RMEI) and to develop receptor-related input parameters for the } \\
\text { updated biosphere model. The entire analysis documentation was revised. }\end{array}$ \\
\hline REV 03 & $\begin{array}{l}\text { Complete revision. Changed source for meteorological data to MO04019SUM9397.000, resulting in } \\
\text { elimination of } 16 \text { data tracking numbers. Changed source of all food consumption survey data to } \\
\text { MO0010SPANYE00.001, resulting in the elimination of MO0106SPAECL02.016. Clarified sample } \\
\text { size of analyses that used the survey data. Added histogram of water consumption. Added } \\
\text { justification for use as direct input soil ingestion data from an outside source that is not an established } \\
\text { fact. Moved assumption of lack of geophagia to Section 6.4.3. Updated references to project } \\
\text { documents that have been revised. Provided additional justification for use of inputs in Sections } 4 \text { and } \\
\text { 6. Corrected half-life of Pu-238 in Table 6-23. Made editorial corrections and style changes. }\end{array}$ \\
\hline
\end{tabular}




\section{CONTENTS}

Page

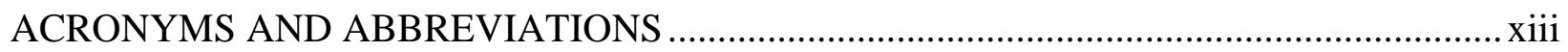

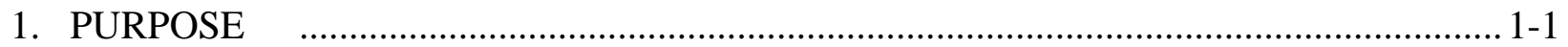

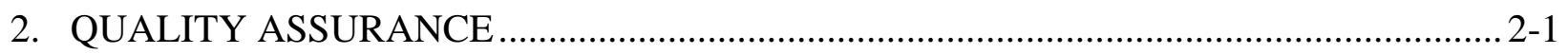

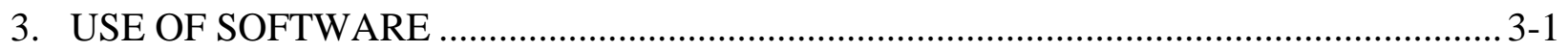

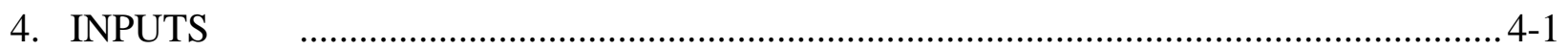

4.1 DIRECT INPUTS …………………………................................................. 4-1

4.1.1 U.S. Census 2000 ................................................................................... 4-2

4.1.2 U.S. Environmental Protection Agency (EPA) Data on Human Activity Patterns............................................................................................ 4-2

4.1.3 Parameters Related to Breathing Rate and the Respiratory Tract Model of ICRP Publication 66 ............................................................................... 4-3

4.1.4 Food and Nutrient Intakes by Individuals in the United States ......................... 4-3

4.1.5 Dietary and Living Style Characteristics ......................................................... 4-4

4.1.6 Meteorological Monitoring Data .................................................................... 4-4

4.1.7 Hourly United States Weather Observations .................................................... 4-5

4.1.8 Inadvertent Soil Ingestion Rate....................................................................... 4-5

4.1.9 Dose Conversion Factors, Dose Coefficients, and Properties of Nuclides ................................................................................................. 4-7

4.1.10 Building Shielding Factors ……………….................................................... 4-8

4.1.11 Other Sources of Direct Inputs in this Analysis............................................... 4-8

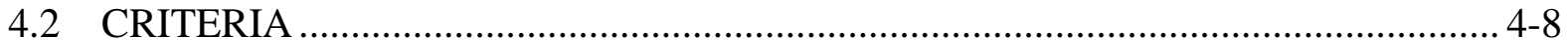

4.3 CODES, STANDARDS, AND REGULATIONS ...................................................... 4-10

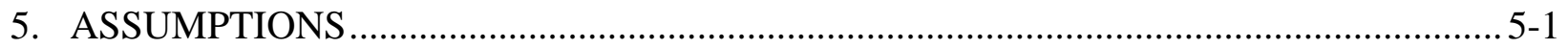

5.1 PROPORTION OF POPULATION-COMMUTERS ............................................... 5-1

5.2 PROPORTION OF POPULATION-LOCAL OUTDOOR WORKERS........................ 5-2

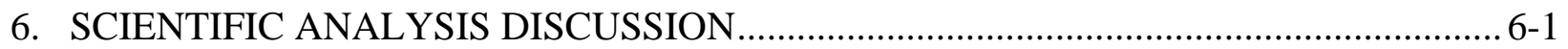

6.1 DEFINITION OF THE RECEPTOR.................................................................. 6-1

6.2 METHODS FOR EVALUATING RECEPTOR RADIATION EXPOSURE,

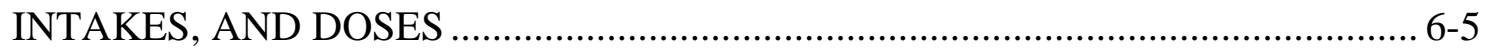

6.2.1 Evaluation of External Exposure .................................................................. 6-8

6.2.2 Evaluation of Inhalation Exposure................................................................... 6-9

6.2.2.1 Inhalation of Airborne Particulates ...................................................6-9

6.2.2.2 Inhalation of Aerosols Produced by Evaporative Coolers .............. 6-10

6.2.2.3 Inhalation of Carbon-14 ............................................................. 6-11

6.2.2.4 Inhalation of Radon Decay Products................................................ 6-11 


\section{CONTENTS (Continued)}

6.2.3 Evaluation of Ingestion Exposure ................................................................. 6-12

6.3 LIFESTYLE CHARACTERISTICS OF THE RECEPTOR ................................... 6-13

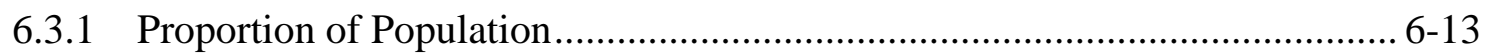

6.3.2 Exposure Times ................................................................................. 6-17

6.3.2.1 Behavior Times ......................................................................... 6-18

6.3.2.2 Exposure Times Per Population Group ………………………....... 6-27

6.3.3 Breathing Rates.................................................................................... 6-31

6.3.4 Evaporative Cooler Use ................................................................... 6-35

6.3.4.1 Fraction of Houses with Evaporative Coolers.................................. 6-36

6.3.4.2 Evaporative Cooler Use Factor ………………………………...... 6-36

6.4 DIETARY CHARACTERISTICS OF THE RECEPTOR ………............................. 6-39

6.4.1 Food Consumption Survey ………………………....................................... 6-39

6.4.2 Calculation of Annual Consumption Rates of Locally Produced Food

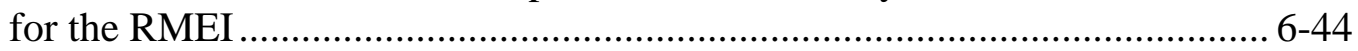

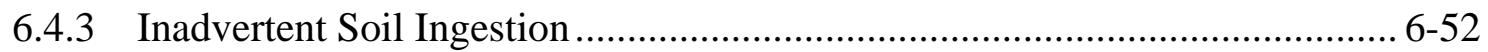

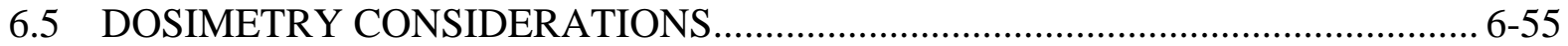

6.5.1 Radionuclides and Elements Included in the Analysis .................................... 6-55

6.5.2 Dosimetric Approaches............................................................................... 6-58

6.5.3 Dose Coefficients for Internal and External Exposure .................................... 6-59

6.5.3.1 Dose Conversion Factors for Inhalation and Ingestion ................... 6-59

6.5.3.2 Dose Coefficients for Exposure to Contaminated Soil .................... 6-60

6.5.3.3 Dose Coefficients for Air Submersion and Water Immersion ....... 6-60

6.5.4 Radon Doses ......................................................................................... 6-67

6.5.5 Dependence of Inhalation Dose Conversion Factors on Particle Sizes ........... 6-68

6.5.5.1 Particle Size Distribution of Environmental Aerosols ..................... 6-68

6.5.5.2 Dosimetric Considerations for Airborne Particulates ...................... 6-71

6.6 BUILDING SHIELDING FACTORS ................................................................ 6-76

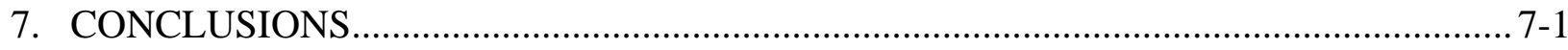

7.1 PARAMETER VALUES...............................................................................

7.1.1 Lifestyle Characteristics of the Receptor ......................................................... 7-1

7.1.1.1 Proportion of Population .................................................................... 7-1

7.1.1.2 Exposure Times by Population Group and Environment................... 7-1

7.1.1.3 Breathing Rates ..............................................................................

7.1.1.4 Evaporative Cooler Use..................................................................

7.1.2 Dietary Characteristics of the Receptor ........................................................... 7-3

7.1.2.1 Consumption Rate of Water ............................................................... 7-3

7.1.2.2 Consumption Rate of Locally Produced Food ................................... 7-3

7.1.2.3 Inadvertent Soil Ingestion ................................................................ 7-3

7.1.3 Dosimetric Parameters ............................................................................. 7-4

7.1.3.1 Radionuclide Half-Lives and Branching Fractions ........................... 7-4

7.1.3.2 Dose Conversion Factors and Dose Coefficients .............................. 7-4 
CONTENTS (Continued)

Page

7.1.3.3 Building Shielding Factors ................................................................ 7-4

7.2 HOW THE APPLICABLE ACCEPTANCE CRITERIA ARE ADDRESSED........... 7-4

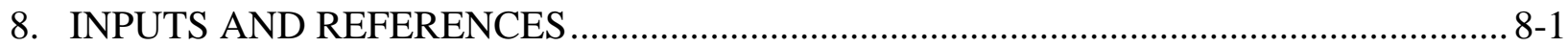

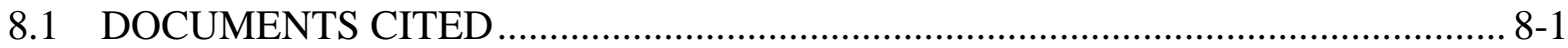

8.2 CODES, STANDARDS, REGULATIONS, AND PROCEDURES ........................... 8-9

8.3 SOURCE DATA, LISTED BY DATA TRACKING NUMBERS ……………........... 8-9

8.4 OUTPUT DATA, LISTED BY DATA TRACKING NUMBER ................................ 8-9

APPENDIX A - CALCULATION OF CONSUMPTION RATES OF LOCALLY PRODUCED FOOD ............................................................................... A-1

APPENDIX B - CALCULATION OF INHALATION DOSE CONVERSION FACTOR RATIOS FOR DIFFERENT SIZE PARTICLES ………………………........

APPENDIX C - FILES SUPPORTING THE ANALYSIS AND CD-ROM …….........................-1 
INTENTIONALLY LEFT BLANK 


\section{FIGURES}

Page

1-1. Biosphere Model Documentation ..................................................................... 1-2

6-1. South Central Nevada Census Geography ............................................................. 6-4

6-2. Evaporative Cooler Use in the Amargosa Valley …................................................. 6-38

6-3. Annual Consumption Rates of Groundwater......................................................... 6-41

6-4. Annual Consumption Rates of Locally Produced Leafy Vegetables........................... 6-41

6-5. Annual Consumption Rates of Locally Produced Other Vegetables............................ 6-41

6-6. Annual Consumption Rates of Locally Produced Fruit ............................................. 6-42

6-7. Annual Consumption Rates of Locally Produced Grain........................................... 6-42

6-8. Annual Consumption Rates of Locally Produced Meat ............................................ 6-43

6-9. Annual Consumption Rates of Locally Produced Poultry ......................................... 6-43

6-10. Annual Consumption Rates of Locally Produced Milk ............................................ 6-43

6-11. Annual Consumption Rates of Locally Produced Eggs............................................ 6-44

6-12. Annual Consumption Rates of Locally Produced Fish............................................... 6-44

6-13. The Ratio of Inhalation Dose Conversion Factors for Particulates of a Given

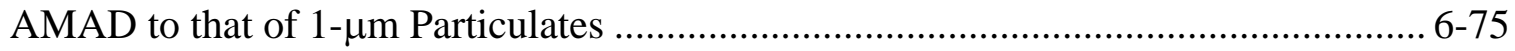

C-1. $\quad$ List of Files Included on CD-ROM …..................................................................... 
INTENTIONALLY LEFT BLANK 


\section{TABLES}

1-1. Parameters and Included Features, Events, and Processes ……………........................ 1-3

4-1. Biosphere Model Input Parameters Developed in This Analysis Report and the Sources of Data ....................................................................................................... 4-1

4-2. Requirements Applicable to this Analysis.................................................................. 4-9

6-1. Biosphere Model Exposure Pathways and Associated Parameters Related to Receptor Characteristics ........................................................................................... 6-6

6-2. Work Status of Amargosa Valley Residents in 1999..................................................... 6-15

6-3. Travel Time to Work for Amargosa Valley Residents .................................................. 6-16

6-4. Industry of Employed Amargosa Valley Residents in 2000 …..................................... 6-17

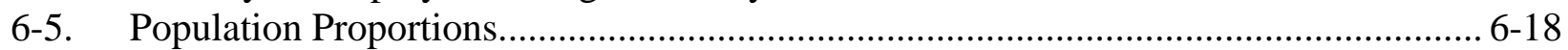

6-6. Estimated Number of Hours Worked Per Year ............................................................. 6-19

6-7. Commute Time (minutes/day) for the Groundwater Exposure Scenario ......................... 6-20

6-8. Commute Time (minutes/day) for the Volcanic Ash Exposure Scenario......................... 6-21

6-9. Weighted Average Amount of Time Spent Per Day in Various Locations..................... 6-23

6-10. Age (years) of Residents of the Amargosa Valley in 2000 ........................................... 6-23

6-11. Average Minutes Spent Active and Inactive Outdoors by Age Groups in 1985 ........... 6-26

6-12. Daily Exposure Times for Amargosa Valley Population Groups.................................. 6-28

6-13. Contributions of Activity Levels by Population Group and Environment ..................... 6-32

6-14. Breathing Rates Per Level of Activity ..................................................................... 6-33

6-15. Calculation of Expected Breathing Rates ………........................................................ 6-33

6-16. Calculation of Aggregated Times Spent in Environments Per Activity Level.............. 6-34

6-17. Percent of Time Spent Outdoors and Indoors Per Activity Level ................................. 6-35

6-18. Evaporative Cooler Use Factor for the Present-Day Climate ......................................... 6-37

6-19. Evaporative Cooler Use Factor for the Upper Bound Glacial Transition Climate ........ 6-38

6-20. Annual Daily Intake and Fraction of People Consuming for Respondents in the Western Region and the Calculated Contingent Annual Daily Consumption by Food Type

6-21. Effective Number of Days for Consumption of Locally Produced Food and Annual Consumption Rates by Survey Food Group and by Biosphere Model Food Type

6-22. Inadvertent Soil Ingestion Rates Reported in the Literature. 6-54

6-23. Primary Radionuclides and Their Decay Products Included in the Biosphere Model. $6-56$

6-24. Dose Conversion Factors for Inhalation and Ingestion of Radionuclides of Interest .... 6-61

6-25. Dose Coefficients for External Exposure to Contaminated Soil for Radionuclides of Interest

6-26. Dose Coefficients for Air Submersion and Water Immersion for Radionuclides of Interest. 


\section{TABLES (Continued)}

Page

6-27. Comparison of Inhalation Dose Conversion Factors Between 1- $\mu \mathrm{m}$ Particles and Other Size Particles

6-28. Shielding Factors for Primary Radionuclides and Their Decay Products ...................... 6-78

7-1. Proportion of the Amargosa Valley Population in Occupation Categories ..................... 7-1

7-2. Daily Exposure Times for Amargosa Valley Population Groups..................................... 7-2

7-3. Breathing Rates by Population Group and Environment................................................ 7-2

7-4. Breathing Rates Per Level of Activity ..................................................................... 7-3

7-5. Annual Consumption Rates of Locally Produced Food by Biosphere Model Food

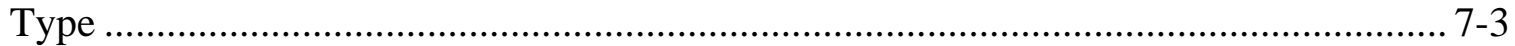

7-6. Building Shielding Factors for Primary Radionuclides .................................................. 7-5 


\section{ACRONYMS AND ABBREVIATIONS}

AMAD activity median aerodynamic diameter

BDCF biosphere dose conversion factor

CADI contingent average daily (food) intake

CEDE committed effective dose equivalent

DCF dose conversion factor

EDE effective dose equivalent

EDPY effective number of days per year

EPA

U.S. Environmental Protection Agency

ERMYN Environmental Radiation Model for Yucca Mountain, Nevada

FEP feature, event, and process

FGR Federal Guidance Report

FPC fraction of people

ICRP International Commission on Radiological Protection

LA license application

NCRP National Council on Radiation Protection and Measurements

NHAPS National Human Activity Pattern Survey

NRC U.S. Nuclear Regulatory Commission

PAEC potential alpha energy concentration

RMEI reasonably maximally exposed individual

TEDE total effective dose equivalent

TSPA total system performance assessment

USDA U.S. Department of Agriculture 


\section{INTENTIONALLY LEFT BLANK}




\section{PURPOSE}

This analysis report is one of a series of technical reports that document the Environmental Radiation Model for Yucca Mountain, Nevada (ERMYN), a biosphere model supporting the total system performance assessment (TSPA) for the geologic repository at Yucca Mountain. This report is one of the five biosphere reports that develop input parameter values for the biosphere model. The Biosphere Model Report (BSC 2004 [DIRS 169460]) describes the conceptual model, as well as the mathematical model and its input parameters.

Figure 1-1 is a graphical representation of the documentation hierarchy for the ERMYN. This figure shows relationships among the products (i.e., scientific analyses and model reports) developed for biosphere modeling and biosphere abstraction products for TSPA, as identified in the Technical Work Plan: for Biosphere Modeling and Expert Support (BSC 2004 [DIRS 169573]).

The purpose of this analysis report is to define values for biosphere model parameters that are related to the dietary, lifestyle, and dosimetric characteristics of the receptor. The biosphere model, consistent with the licensing rule at 10 CFR Part 63 [DIRS 156605], uses a hypothetical person called the reasonably maximally exposed individual (RMEI) to represent the potentially exposed population. The parameters that define the RMEI are based on the behaviors and characteristics of the residents of the unincorporated town of Amargosa Valley, consistent with the requirements of 10 CFR 63.312 [DIRS 156605]. The output of this report is used as direct input in the two analyses identified in Figure 1-1 that calculate the values of biosphere dose conversion factors (BDCFs) for the groundwater and volcanic ash exposure scenarios. The parameter values developed in this report are reflected in the TSPA through the BDCFs. The analysis was performed in accordance with AP-SIII.9Q, Scientific Analyses, and the technical work plan (BSC 2004 [DIRS 169573]).

This analysis supports the treatment of 15 features, events, and processes (FEPs) applicable to the reference biosphere (Table 1-1). See the Biosphere Model Report (BSC 2004 [DIRS 169460], Section 6.2) for information on treatment of FEPs in the biosphere model. Use of MO0407SEPFEPLA.000 [DIRS 170760] in Table 1-1 is a deviation from the technical work plan (BSC 2004 [DIRS 169573]); that plan refers to an earlier revision of the FEP list.

Biosphere modeling focuses on radionuclides screened for the TSPA-license application (LA) (BSC 2004 [DIRS 169460], Section 6.1.3). The same list of radionuclides is used in this analysis (Section 6.5.1). The analysis includes consideration of two human exposure scenarios: groundwater and volcanic ash. For the groundwater exposure scenario, radionuclides enter the biosphere from a well that extracts contaminated groundwater from an aquifer. Human exposure arises from using the contaminated water for domestic and agricultural purposes. The groundwater scenario applies to the TSPA-LA modeling cases that consider groundwater release of radionuclides from the repository at Yucca Mountain. The nominal scenario class and some modeling cases from the disruptive scenario classes (i.e., igneous intrusion or human intrusion) may result in the release of radionuclides to groundwater. For the volcanic ash scenario, the mode of radionuclide release into the biosphere is a volcanic eruption through the repository with the resulting entrainment of contaminated waste in the ash and other tephra and the subsequent atmospheric transport and dispersion of contaminated material in the biosphere. This scenario 
applies to the volcanic eruption modeling case of the igneous scenario class (BSC 2003 [DIRS 166296], Section 4.2), which is one of the TSPA disruptive scenario classes.

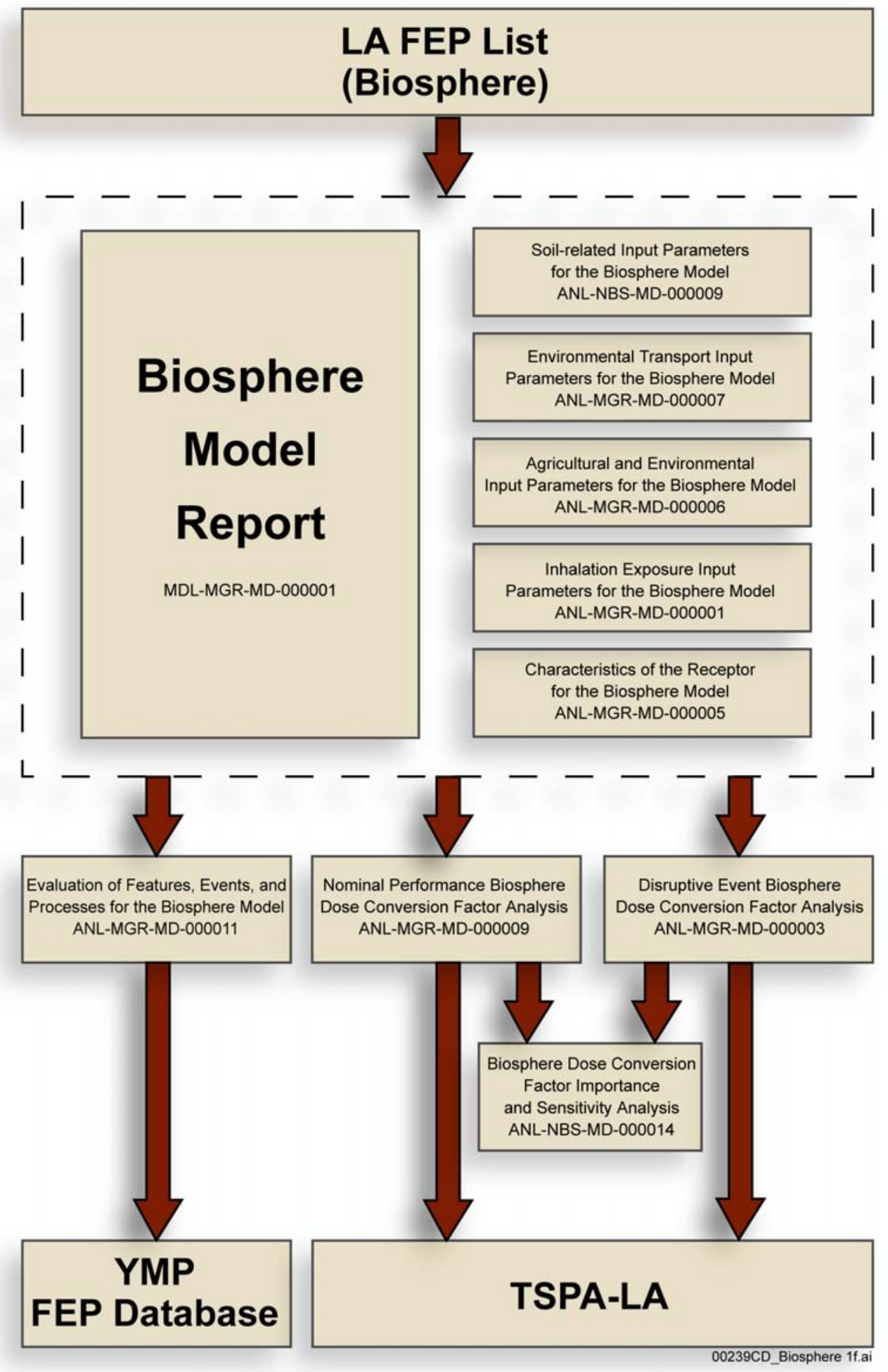

Figure 1-1. Biosphere Model Documentation 


\begin{tabular}{|c|c|c|c|c|}
\hline Parameter(s) & FEP $^{a}$ & $\begin{array}{l}\text { YMP FEP } \\
\text { Number }^{\mathrm{a}}\end{array}$ & $\begin{array}{l}\text { Associated } \\
\text { Submodel(s) }\end{array}$ & Summary of Disposition ${ }^{b}$ \\
\hline \multirow{3}{*}{ Population proportion } & Human lifestyle & 2.4.04.01.0A & \multirow{3}{*}{$\begin{array}{l}\text { External exposure, } \\
\text { Inhalation }\end{array}$} & \multirow{3}{*}{$\begin{array}{l}\text { The treatment of this parameter is described in } \\
\text { Section 6.3.1 and summarized in Table 6-5. }\end{array}$} \\
\hline & Inhalation & 3.3.04.02.0A & & \\
\hline & External exposure & 3.3.04.03.0A & & \\
\hline \multirow{6}{*}{ Exposure time } & External exposure & 3.3.04.03.0A & \multirow{6}{*}{$\begin{array}{l}\text { External exposure, } \\
\text { Inhalation }\end{array}$} & \multirow{6}{*}{$\begin{array}{l}\text { The treatment of this parameter is described in } \\
\text { Section 6.3.2 and summarized in Table 6-12. }\end{array}$} \\
\hline & Human lifestyle & 2.4.04.01.0A & & \\
\hline & Wild and natural land and water use & 2.4.08.00.0A & & \\
\hline & Agricultural land use and irrigation & 2.4.09.01.0B & & \\
\hline & Urban and industrial land and water use & 2.4.10.00.0A & & \\
\hline & Inhalation & 3.3.04.02.0A & & \\
\hline \multirow[t]{2}{*}{ Breathing rate } & $\begin{array}{l}\text { Human characteristics (physiology, } \\
\text { metabolism) }\end{array}$ & 2.4.01.00.0A & \multirow[t]{2}{*}{ Inhalation } & \multirow{2}{*}{$\begin{array}{l}\text { The treatment of this parameter is described in } \\
\text { Section 6.3.3 and summarized in Table } 6-15 \text {. }\end{array}$} \\
\hline & Inhalation & 3.3.04.02.0A & & \\
\hline \multirow{2}{*}{$\begin{array}{l}\text { Fraction of houses with } \\
\text { evaporative coolers }\end{array}$} & Dwellings & 2.4.07.00.0A & \multirow{2}{*}{ Inhalation } & \multirow{2}{*}{$\begin{array}{l}\text { The treatment of this parameter is described in } \\
\text { Section 6.3.4.1. }\end{array}$} \\
\hline & Inhalation & 3.3.04.02.0A & & \\
\hline \multirow{4}{*}{$\begin{array}{l}\text { Evaporative cooler use } \\
\text { factor }\end{array}$} & Climate change & 1.3.01.00.0A & \multirow{4}{*}{ Inhalation } & \multirow{4}{*}{$\begin{array}{l}\text { The treatment of this parameter is described in } \\
\text { Section 6.3.4.2. }\end{array}$} \\
\hline & Biosphere characteristics & 2.3.13.01.0A & & \\
\hline & Dwellings & 2.4.07.00.0A & & \\
\hline & Inhalation & 3.3.04.02.0A & & \\
\hline \multirow{3}{*}{$\begin{array}{l}\text { Consumption rate of } \\
\text { locally produced food } \\
\text { (including water) }\end{array}$} & $\begin{array}{l}\text { Contaminated drinking water, foodstuffs } \\
\text { and drugs }\end{array}$ & 3.3.01.00.0A & \multirow{3}{*}{ Ingestion } & \multirow{3}{*}{$\begin{array}{l}\text { The treatment of this parameter is described in } \\
\text { Section } 6.4 \text {. The consumption rate of water is } \\
\text { described in Section } 6.4 \text {. The consumption rate } \\
\text { of food is described in Section } 6.4 .2 \text { and } \\
\text { summarized in Table 6-21. }\end{array}$} \\
\hline & Wild and natural land and water use & 2.4.08.00.0A & & \\
\hline & Ingestion & 3.3.04.01.0A & & \\
\hline \multirow{2}{*}{$\begin{array}{l}\text { Annual inadvertent soil } \\
\text { ingestion rate }\end{array}$} & $\begin{array}{l}\text { Contaminated drinking water, foodstuffs } \\
\text { and drugs }\end{array}$ & 3.3.01.00.0A & \multirow[t]{2}{*}{ Ingestion } & \multirow{2}{*}{$\begin{array}{l}\text { The treatment of this parameter is described in } \\
\text { Section 6.4.3. }\end{array}$} \\
\hline & Ingestion & 3.3.04.01.0A & & \\
\hline $\begin{array}{l}\text { Radionuclide half-lives } \\
\text { and branching fractions }\end{array}$ & Radioactive decay and ingrowth & 3.1.01.01.0A & $\begin{array}{l}\text { Inhalation, } \\
\text { Ingestion, External } \\
\text { Exposure }\end{array}$ & $\begin{array}{l}\text { The treatment of this parameter is described in } \\
\text { Section 6.5.1 and summarized in Table } 6-23 \text {. }\end{array}$ \\
\hline
\end{tabular}


Table 1-1. Parameters and Included Features, Events, and Processes (Continued)

\begin{tabular}{|c|c|c|c|c|}
\hline Parameter(s) & FEP $^{a}$ & $\begin{array}{l}\text { YMP FEP } \\
\text { Number }^{a}\end{array}$ & $\begin{array}{l}\text { Associated } \\
\text { Submodel(s) }\end{array}$ & Summary of Disposition ${ }^{b}$ \\
\hline \multirow{4}{*}{$\begin{array}{l}\text { Dose conversion factors } \\
\text { for inhalation }\end{array}$} & $\begin{array}{l}\text { Human characteristics (physiology, } \\
\text { metabolism) }\end{array}$ & 2.4.01.00.0A & \multirow{4}{*}{ Inhalation } & \multirow{4}{*}{$\begin{array}{l}\text { The treatment of this parameter is described in } \\
\text { Section 6.5.3.1 and summarized in Table 6-24. }\end{array}$} \\
\hline & Inhalation & 3.3.04.02.0A & & \\
\hline & Radioactive decay and ingrowth & 3.1.01.01.0A & & \\
\hline & Radiation doses & 3.3.05.01.0A & & \\
\hline \multirow{4}{*}{$\begin{array}{l}\text { Dose conversion factors } \\
\text { for ingestion }\end{array}$} & $\begin{array}{l}\text { Human characteristics (physiology, } \\
\text { metabolism) }\end{array}$ & 2.4.01.00.0A & \multirow{4}{*}{ Ingestion } & \multirow{4}{*}{$\begin{array}{l}\text { The treatment of this parameter is described in } \\
\text { Section 6.5.3.1 and summarized in Table } 6-24 \text {. }\end{array}$} \\
\hline & Ingestion & 3.3.04.01.0A & & \\
\hline & Radioactive decay and ingrowth & 3.1.01.01.0A & & \\
\hline & Radiation doses & 3.3.05.01.0A & & \\
\hline \multirow{4}{*}{$\begin{array}{l}\text { Dose coefficient for } \\
\text { exposure to } \\
\text { contaminated ground } \\
\text { surface }\end{array}$} & $\begin{array}{l}\text { Human characteristics (physiology, } \\
\text { metabolism) }\end{array}$ & 2.4.01.00.0A & \multirow{4}{*}{ External exposure } & \multirow{4}{*}{$\begin{array}{l}\text { The treatment of this parameter is described in } \\
\text { Section 6.5.3.2 and summarized in Table 6-25. }\end{array}$} \\
\hline & External exposure & 3.3.04.03.0A & & \\
\hline & Radioactive decay and ingrowth & 3.1.01.01.0A & & \\
\hline & Radiation doses & 3.3.05.01.0A & & \\
\hline \multirow{4}{*}{$\begin{array}{l}\text { Dose coefficient for } \\
\text { exposure to soil } \\
\text { contaminated to an } \\
\text { infinite depth }\end{array}$} & $\begin{array}{l}\text { Human characteristics (physiology, } \\
\text { metabolism) }\end{array}$ & 2.4.01.00.0A & \multirow{4}{*}{ External exposure } & \multirow{4}{*}{$\begin{array}{l}\text { The treatment of this parameter is described in } \\
\text { Section 6.5.3.2 and summarized in Table } 6-25 \text {. }\end{array}$} \\
\hline & External exposure & 3.3.04.03.0A & & \\
\hline & Radioactive decay and ingrowth & 3.1.01.01.0A & & \\
\hline & Radiation doses & 3.3.05.01.0A & & \\
\hline \multirow{5}{*}{$\begin{array}{l}\text { Dose conversion factor } \\
\text { for inhalation of radon } \\
\text { decay products }\end{array}$} & $\begin{array}{l}\text { Human characteristics (physiology, } \\
\text { metabolism) }\end{array}$ & 2.4.01.00.0A & \multirow{5}{*}{ Inhalation } & \multirow{5}{*}{$\begin{array}{l}\text { The treatment of this parameter is described in } \\
\text { Section } 6.5 .4 \text {. }\end{array}$} \\
\hline & Inhalation & 3.3.04.02.0A & & \\
\hline & Radioactive decay and ingrowth & 3.1.01.01.0A & & \\
\hline & Radon and radon daughter exposure & 3.3.08.00.0A & & \\
\hline & Radiation doses & 3.3.05.01.0A & & \\
\hline \multirow{2}{*}{ Building shielding factor } & Dwellings & 2.4.07.00.0A & \multirow[t]{2}{*}{ External exposure } & \multirow{2}{*}{$\begin{array}{l}\text { The treatment of this parameter is described in } \\
\text { Section } 6.6 \text { and summarized in Table } 6-28 \text {. }\end{array}$} \\
\hline & External exposure & 3.3.04.03.0A & & \\
\hline
\end{tabular}

${ }_{\mathrm{b}}^{\mathrm{a}}$ Features, events, and processes are from the LA FEP List (DTN: MO0407SEPFEPLA.000 [DIRS 170760]).

${ }^{b}$ The effects of the related FEPs are included in the TSPA through the BDCFs. See the Biosphere Model Report (BSC 2004 [DIRS 169460], Section 6.2) for a complete description of the inclusion and treatment of listed FEPs in the biosphere model.

$\mathrm{BDCF}=$ biosphere dose conversion factor; FEP=feature, event, and process; YMP = Yucca Mountain Project 


\section{QUALITY ASSURANCE}

Development of this report involves analysis of data to support performance assessment as identified in the technical work plan (BSC 2004 [DIRS 169573]) and is a quality-affecting activity in accordance with AP-2.27Q, Planning for Science Activities. Approved quality assurance procedures identified in Section 4 of the technical work plan have been used to conduct and document the activities described in this report. Electronic data used in this analysis were controlled in accordance with the methods specified in Section 8 of the technical work plan.

The natural barriers and items identified in the Q-List (BSC 2004 [DIRS 168361]) are not pertinent to this analysis, and a safety category per AP-2.22Q, Classification Analysis and Maintenance of the Q List, is not applicable. 


\section{INTENTIONALLY LEFT BLANK}




\section{USE OF SOFTWARE}

The only software used during this analysis was the commercial, off-the-shelf product Microsoft Excel (Version 97 SR-2). Standard Excel functions were used to calculate parameter values, as described in the appendices to this document, and to produce histograms shown in Section 6 of this report. Use of the Excel functions, including formulas or algorithms, inputs, and outputs, are described in the appendices. 


\section{INTENTIONALLY LEFT BLANK}




\section{INPUTS}

\subsection{DIRECT INPUTS}

The list of parameters related to the characteristics of the receptor for the biosphere model addressed in this analysis and the sources of direct input used to develop the parameter values are shown in Table 4-1.

Table 4-1. Biosphere Model Input Parameters Developed in This Analysis Report and the Sources of Data

\begin{tabular}{|c|c|}
\hline Parameter & Sources of Direct Input \\
\hline Population proportion & Bureau of the Census 2002 (DIRS 159728) \\
\hline \multirow[b]{2}{*}{ Exposure time } & Bureau of the Census 2002 (DIRS 159728) \\
\hline & $\begin{array}{l}\text { EPA } 1997 \text { (DIRS 116135) } \\
\text { Klepeis et al. } 1996 \text { (DIRS 159299) } \\
\text { Lide and Frederikse } 1997 \text { (DIRS 103178) }\end{array}$ \\
\hline \multirow{2}{*}{ Breathing rate } & ICRP 1994 (DIRS 153705) \\
\hline & Bureau of the Census 2002 (DIRS 159728) \\
\hline Fraction of houses with evaporative coolers & $\begin{array}{l}\text { DTN: MO0010SPANYE00.001 (DIRS 154976) } \\
\text { Cleaned Nye County Food Consumption Frequency } \\
\text { Survey }\end{array}$ \\
\hline \multirow[t]{2}{*}{ Evaporative cooler use factor } & $\begin{array}{l}\text { DTN: MO04019SUM9397.000 (DIRS 167054) } \\
\text { Summary of 1993-1997 Site } 9 \text { Meteorological Data }\end{array}$ \\
\hline & National Climatic Data Center [n.d.] (DIRS 161091) \\
\hline \multirow{4}{*}{$\begin{array}{l}\text { Consumption rate of locally produced food (including } \\
\text { water) }\end{array}$} & $\begin{array}{l}\text { DTN: MO0010SPANYE00.001 (DIRS 154976) } \\
\text { Cleaned Nye County Food Consumption Frequency } \\
\text { Survey }\end{array}$ \\
\hline & USDA 2000 (DIRS 154158) \\
\hline & Bureau of the Census 2002 (DIRS 159728) \\
\hline & 10 CFR Part 63 (DIRS 156605) \\
\hline Inadvertent soil ingestion rate & $\begin{array}{l}\text { EPA } 1997 \text { (DIRS 103038) } \\
\text { Simon } 1998 \text { (DIRS 160098) }\end{array}$ \\
\hline Radionuclide half-lives and branching fractions & $\begin{array}{l}\text { Eckerman and Ryman } 1993 \text { (DIRS 107684) } \\
\text { Lide and Frederikse } 1997 \text { (DIRS 103178) }\end{array}$ \\
\hline Dose conversion factor for inhalation by radionuclide & Eckerman et al. 1988 (DIRS 101069) \\
\hline Dose conversion factor for ingestion by radionuclide & Eckerman et al. 1988 (DIRS 101069) \\
\hline $\begin{array}{l}\text { Dose coefficient for exposure to contaminated ground } \\
\text { surface }\end{array}$ & Eckerman and Ryman 1993 (DIRS 107684) \\
\hline $\begin{array}{l}\text { Dose coefficient for exposure to soil contaminated to an } \\
\text { infinite depth }\end{array}$ & Eckerman and Ryman 1993 (DIRS 107684) \\
\hline $\begin{array}{l}\text { Dose conversion factor for inhalation of radon decay } \\
\text { products }\end{array}$ & $\begin{array}{l}\text { ICRP } 1981 \text { (DIRS 163051) } \\
\text { Eckerman et al. } 1988 \text { (DIRS 101069) } \\
10 \text { CFR Part } 20 \text { (DIRS 104787) }\end{array}$ \\
\hline
\end{tabular}


Table 4-1. Biosphere Model Input Parameters Developed in This Analysis Report and the Sources of Data (Continued)

\begin{tabular}{|l|l|}
\hline \multicolumn{1}{|c|}{ Parameter } & \multicolumn{1}{|c|}{ Sources of Direct Input } \\
\hline & NCRP 1999 (DIRS 155894) \\
Building shielding factor & $\begin{array}{l}\text { Bureau of the Census 2002 (DIRS 159728) } \\
\text { Lide and Frederikse 1977 (DIRS 103178) } \\
\text { Eckerman and Ryman 1993 (DIRS 107684) }\end{array}$ \\
\hline
\end{tabular}

\subsubsection{U.S. Census 2000}

Information on population size, age distribution, industry of employment, and travel time of the residents of the Amargosa Valley census county division from the 2000 census conducted by the Bureau of the Census (2002 [DIRS 159728]) were used in Sections 5.2 and 6.3.1 to determine the proportion of the population of the Amargosa Valley in four population groups. This information also was used to develop distributions of the time the population groups spend in five environments (Section 6.3.2), calculate gender-weighted breathing rates (Section 6.3.3) and food consumption rates (Section 6.4.2), and determine the types of dwellings in the Amargosa Valley (Section 6.6).

The 2000 census data are appropriate for use in this analysis and considered established fact as they are based on the most recent and comprehensive census of the Amargosa Valley population conducted by the U.S. Bureau of the Census. The data are specific to the people who reside in the Amargosa Valley, consistent with the requirements of 10 CFR 63.312(b) [DIRS 156605] and discussed in Section 6.1. The data were collected and summarized in accordance with the requirements of the Census Bureau for census data. The U.S. Bureau of the Census is the federal agency chartered to collect, analyze, and supply key economic and demographic data. The data used in this analysis are identified and presented in Tables 6-2, 6-3, 6-4, 6-6, 6-7, 6-8, and 6-10.

\subsubsection{U.S. Environmental Protection Agency Data on Human Activity Patterns}

Estimates from the Exposure Factors Handbook (EPA 1997 [DIRS 116135]) and the Analysis of the National Human Activity Pattern Survey (NHAPS) Respondents from a Standpoint of Exposure Assessment (Klepeis et al. 1996 [DIRS 159299]) of time spent in various activities and locations were used to develop distributions of exposure times (Section 6.3.2). This information is appropriate for this use because the NHAPS and associated data in the Exposure Factors Handbook (EPA 1997 [DIRS 116135]) were collected by the EPA, and because this is the largest and most complete compilation of activity patterns and time spent exposed to toxic pollutants by people in the U.S. (EPA 1997 [DIRS 116135], p. 15-5; Klepeis 1999 [DIRS 160094], pp. 368 to 371).

The purpose of the Exposure Factors Handbook is to "(1) summarize data on human behavior and characteristics which affect exposure to environmental contaminants, and (2) recommend values to use for these factors" (EPA 1997 [DIRS 103038], p. 1-1). The handbook is intended to support and promote consistency among exposure assessment activities carried out by the EPA. As such, this information is recognized as an authoritative source of exposure factors by the scientific community, and is therefore appropriate for use in this analysis and considered established fact. For the 1992-1994 NHAPS, minute-by-minute, 24-hour diaries were kept by 
9,386 people in the 48 contiguous U.S. states. The data were collected, summarized, and analyzed in accordance with rigorous, well-defined methodologies, as described by Klepeis et al. (1996 [DIRS 159299]). Applicability of data from this national survey to conditions in the Amargosa Valley is described in Section 6.3.2. The data used in this analysis are identified and presented in Tables 6-9 and 6-11.

\subsubsection{Parameters Related to Breathing Rate and the Respiratory Tract Model of ICRP Publication 66}

Information related to the respiratory tract model of International Commission on Radiation Protection (ICRP) Publication 66 (ICRP 1994 [DIRS 153705]), including the breathing rates and the nominal mix of exercise levels for various environments, was used to develop the values of breathing rate by population group and environment for the biosphere model (Section 6.3.3). The data used in this analysis are identified and presented in Tables 6-13 and 6-14.

The ICRP is an international, independent, non-governmental advisory organization established to advance for the public benefit the science of radiological protection, in particular by providing recommendations and guidance on protection against ionizing radiation. The U.S. National Council on Radiation Protection and Measurements (NCRP, see Section 4.1.10) works closely with international bodies, such as the ICRP, so that its recommendations reflect the consensus of leading scientific thinking. These recommendations are considered for adoption by U.S. governmental organizations, including the U.S. Nuclear Regulatory Commission (NRC), the Public Health Service, the EPA, and state governments, to support specific advice, codes of practice, regulatory requirements, or other radiation protection activities.

The dosimetric model of the respiratory tract used in the biosphere model is that of ICRP Publication 30 (ICRP 1979 [DIRS 110386], Section 5). This is consistent with the concept of total effective dose equivalent (Section 6.5.2). ICRP Publication 30 does not consider breathing rates for various levels of activity; instead, it uses the breathing rate of the reference man under conditions of light activity (ICRP 1979 [DIRS 110386], Section 3.4). The ICRP Publication 66 (ICRP 1994 [DIRS 153705]) data include the most recent recommended values of breathing rates for people involved in various levels of activity (sleeping, sitting, light exercise, heavy exercise). These activity-dependent breathing rates are used to calculate environment-dependent breathing rates for the biosphere model and are appropriate for their intended use and considered established fact.

\subsubsection{Food and Nutrient Intakes by Individuals in the United States}

Information from the U.S. Department of Agriculture (USDA) Food and Nutrient Intakes by Individuals in the United States, 1994-1996 (USDA 2000 [DIRS 154158]) was used in this analysis to develop consumption rate values for the receptor. This report is one in a series of nationwide dietary intake surveys conducted periodically by the USDA. These surveys are an authoritative source of information on the food consumption patterns for various segments of the U.S. population. The survey data used in this analysis included the values of average daily intake of food by food categories, the fraction of population consuming the food in these categories, and the errors associated with these values for the western region of the United States. The USDA data are appropriate for use in this analysis because they are based on a large 
sample of consumption rates and reflect the dietary intake of the surveyed individuals, which on average, are not expected to differ among populations. The USDA consumption data are thus considered established fact and appropriate for use in this analysis. The values were used to develop the probability distribution functions for the consumption rates of locally produced food (Section 6.4.2 and Table 6-20).

\subsubsection{Dietary and Living Style Characteristics}

Information on the dietary and lifestyle characteristics of the people who reside in the town of Amargosa Valley was obtained from a survey of the residents of the Yucca Mountain region. This survey is described in The 1997 "Biosphere" Food Consumption Survey Summary Findings and Technical Documentation (DOE 1997 [DIRS 100332]; DTN: MO0010SPANYE00.001 [DIRS 154976]). The objective of the survey was to collect dietary and socioeconomic information for biosphere modeling. Dietary and lifestyle data were collected from adults residing within 50 miles of Yucca Mountain. Nearly 13,000 adults were estimated to reside in that area at the time of the survey, with about 900 of them in the Amargosa Valley (DOE 1997 [DIRS 100332], p. vi). The survey sample consisted of 1,079 responses, with an Amargosa Valley sample of 195 (DOE 1997 [DIRS 100332], Table 2.3.1). To meet the requirements of 10 CFR 63.312(b), only information from full-time residents of the Amargosa Valley was used in this analysis (see Section 6 and Appendix A). Information from eight people who were seasonal or part-time residents, had resided in Amargosa Valley for less than 1 year, or refused to answer questions about residency were not considered in this analysis. The data that were used in this analysis from the 187 respondents and from the eight that were eliminated are displayed in Appendix C (file Consumption rates with uncertainties.xls).

Data on food consumption frequencies were used to develop consumption rates for locally produced food (Section 6.4.2 and Table 6-21), and data related to evaporative cooler use were used to develop a distribution of the proportion of homes with evaporative coolers (Section 6.3.4). These data are appropriate because they are from a survey of the diet and living style of the people residing in the Amargosa Valley and are consistent with the requirements of 10 CFR 63.312(b) [DIRS 156605].

\subsubsection{Meteorological Monitoring Data}

The information regarding temperature for the Amargosa Valley was obtained from the data for Meteorological Monitoring Site 9, which is the southern most Yucca Mountain Site station in the direction of Amargosa Valley. The data for 1994 to 1997 were summarized in BSC 2004 [DIRS 167055] and are available in DTN: MO04019SUM9397.000 [DIRS 167054]. Summaries of the number of days per year that the temperature exceeded 80, 85, and 90 degrees $F$ are displayed in Table 6-18 and were used to develop the evaporative cooler use factor for the Amargosa Valley in Section 6.3.4.2. The meteorological data for Meteorological Monitoring Site 9 are appropriate for use in this analysis because this site is located in northern Amargosa Valley at Gate 510 along the southern boundary of the Nevada Test Site (CRWMS M\&O 1999 [DIRS 102877], p.5), at the approximate boundary of the accessible environment defined in 10 CFR 63.302 [DIRS 156605]. 


\subsubsection{Hourly United States Weather Observations}

Hourly temperatures collected during 1990 through 1995 from the weather station at Spokane International Airport (Station ID 24157) were used to develop the evaporative cooler use factor for the glacial transition climate predicted to occur in the future at Yucca Mountain (Section 6.3.4.2). These data are appropriate for this use and considered established fact because the current climate at Spokane, Washington, is predicted to be representative of the future climate at Yucca Mountain during a glacial transition period (BSC 2004 [DIRS 170002], Table 6-1). The data were obtained from the National Climatic Data Center (NCDC [n.d.] [DIRS 161091]), and were collected and summarized using the standardized methods of that agency. The data used in this analysis are in Appendix C, Spokane Hourly Temperatures and Daily Max Temperatures.xls.

\subsubsection{Inadvertent Soil Ingestion Rate}

The soil ingestion rate is developed in Section 6.4.3 is based on the mean values of inadvertent soil ingestion recommended in the Exposure Factors Handbook (EPA 1997 [DIRS 103038], Section 4) and by Simon (1998 [DIRS 160098]).

The Exposure Factors Handbook recommends a mean soil ingestion rate of $100 \mathrm{mg} /$ day for adults in residential and agricultural scenarios (EPA 1997 [DIRS 103038], p. 4-21). No recommendation is given for a distribution of rates. This handbook summarizes data on human behaviors and characteristics that affect exposure to environmental contaminants and recommends values to use for those factors (EPA 1997 [DIRS 103038], p. 1-1). The handbook summarizes relevant information and includes a discussion and review of data applicability and related issues. The handbook is intended to serve as a support document to the EPA Guidelines for Exposure Assessment (as cited in EPA 1997 [DIRS 103038], p. 1-1), which was developed to promote consistency among the various exposure assessment activities by providing a consistent set of exposure factors for calculating dose. As such, the scientific community recognizes this information as an authoritative source of exposure factors.

Simon (1998 [DIRS 160098]) reviewed literature on soil ingestion and recommended distributions of soil ingestion rates for adults in various outdoor occupations and environments. The geometric means of the distributions representative of agricultural occupations and rural lifestyles used in this analysis ranged from 50 to $200 \mathrm{mg} / \mathrm{d}$ (Simon 1998 [DIRS 160098], Table 4). The following information was considered to evaluate whether confidence in the data development methods used in that publication are warranted and to determine whether the information used from that publication is suitable for use in this analysis.

- Reliability of the Data Source-Because there is no information available on soil ingestion rates for the specific conditions at Yucca Mountain, the recommended value must be based on a thorough review of data from a wide variety of conditions to be acceptable for the intended use in this analysis. Simon (1998 [DIRS 160098]) includes a comprehensive review of data on soil ingestion with an emphasis on risk assessments for soils contaminated with radionuclides. This article summarizes original research on soil ingestion, other published reviews of the topic, and distributions of ingestion rates used in risk assessment models. More than 175 references are cited. The article considers the 
influence of lifestyle, occupation, and environmental conditions on ingestion rates. In addition, different distributions are recommended for various occupations and conditions. Because this is a comprehensive review of soil ingestion rates, it is considered a reliable summary of information on soil ingestion rates.

- Qualifications of Personnel and Organizations Generating the Data-The article was published as a special review paper in Health Physics. Health Physics is a peer-reviewed technical journal, which is an official publication of the Health Physics Society. The journal adheres to high standards for published articles, which are subject to review by experts in the field. The author was affiliated with the Board on Radiation Effects Research of the National Research Council, National Academy of Sciences. Authorship by an individual associated with a respected organization and publication as a review article in a highly respected, peer-reviewed article raises the confidence that the data are suitable for the intended use.

- Extent to Which the Data Demonstrate the Properties of Interest-The geometric mean values recommended by Simon (1998 [DIRS 160098], Table 4) are used to develop the distribution range for inadvertent soil ingestion by adults in the Yucca Mountain region, a rural, arid area. The article reviews numerous estimates of soil ingestion by adults and considers the influence of lifestyle, occupation, and environmental conditions on ingestion rates. The data upon which the recommended values are based therefore demonstrate the properties of interest required for this analysis.

- Availability of Corroborating Data-There are few data available to corroborate the geometric standard deviation recommended by Simon (1998 [DIRS 160098]). The article includes a comprehensive review of available literature, and there have been few studies of soil ingestion published since 1998. The following three reports, which were not reviewed by Simon (1998 [DIRS 160098]), were examined.

Stanek et al. (1997 [DIRS 160251]) report soil ingestion rates for 10 adults. Although the average ingestion rate is lower than reported in most other studies, they conclude that there is substantial uncertainty as to the best estimate of the rate (Stanek et al. 1997 [DIRS 160251], p. 255). In a separate study of 64 children, Stanek and Calabrese (2000 [DIRS 168391]) also report high uncertainty in soil ingestion rates. These studies corroborate that a large distribution range, as recommended by Simon (1998 [DIRS 160098]), is warranted.

Binkowitz and Wartenberg (2001 [DIRS 168389]) reviewed distributions of soil ingestion rates and other input parameter distributions that have been used in risk assessment. All but one of the studies of soil ingestion rates listed by Binkowitz and Wartenberg (2001 [DIRS 168389], Table VII), and all but three of the models listed, also were reviewed by Simon (1998 [DIRS 160098]). The study not reviewed by Simon was a report of sources of lead ingested by children. The models not listed were a description of stochastic modeling methods, a study of the relationship between lead in soil and blood pressure, and a draft risk assessment model from Oregon. Thus, the report and models are not directly applicable to a review of soil ingestion. This 
comparison corroborates that Simon (1998 [DIRS 160098]) includes a thorough review of literature on soil ingestion rates.

Because the distributions recommended by Simon (1998 [DIRS 160098]) are based on a thorough review of applicable information on soil ingestion, and because additional information corroborates the conclusion of Simon (1998 [DIRS 160098], p. 661) that there is large uncertainty in soil ingestion rates, these data are appropriately justified and suitable for the specific application in this analysis; therefore, the data are considered qualified for their intended use. Confidence that the data are appropriate is raised, because the data were published in a peer-reviewed article from a reputable journal, which was written by a person from a respected organization that is independent of the U.S. Department of Energy.

\subsubsection{Dose Conversion Factors, Dose Coefficients, and Properties of Nuclides}

Dose conversion factors (DCFs) and dose coefficients are expressions of specific dosimetric models and are used for converting radionuclide intake by inhalation and ingestion, as well as by exposure to sources external to the body, to radiation doses. The dose conversion factors (DCFs) and dose coefficients developed in this report are based on information from EPA Federal Guidance Report (FGR) No. 11 (Eckerman et al. 1988 [DIRS 101069]) and EPA FGR No. 12 (Eckerman and Ryman 1993 [DIRS 107684]). The data used are identified and displayed in Tables 6-24, 6-25, and 6-26. Further discussion on the DCFs and dose coefficients can be found in Section 6.5.3 and 6.5.4. In addition, the dose coefficients from Eckerman and Ryman (1993 [DIRS 107684]) for some radionuclides were used to determine the appropriate shielding factors (Section 6.6).

These DCFs are considered established fact and appropriate for use in this analysis for the following reasons. DCFs tabulated in FGR No. 11, and dose coefficients tabulated in FGR No. 12, allow calculating total effective dose equivalent, as defined in 10 CFR 63.2 [DIRS 156605]. The use of DCFs and dose coefficients from these sources is appropriate, because they are the authoritative source of dose coefficients for compliance with the NRC guidance on performance assessment methodology (NRC 2000 [DIRS 157704], Sections 3.3.7.3.1 and 3.3.7.3.2). In addition, the DCFs and dose coefficients developed in these reports are consistent with the individual protection standard defined in terms of total effective dose equivalent (TEDE) and the requirement in 10 CFR 63.312(e) (DIRS 156605) that the RMEI is an adult with metabolic and physiological considerations consistent with present knowledge of adults.

DCFs for inhalation of radon decay products were developed based on ICRP Publication 32 (1981 [DIRS 163051]) and FGR No. 11 (Eckerman et al. 1988 [DIRS 101069]). The values from ICRP Publication 32 are consistent with the ICRP Publication 30 dose methodology (as described in pp. 1 and 2 of ICRP 1981 [DIRS 163051]), and thus with NRC guidance (NRC 2000 [DIRS 157704], Section 3.3.7.1.2).

The data from FGR No. 12 (Eckerman and Ryman 1993 [DIRS 107684]) and the CRC Handbook of Chemistry and Physics (Lide and Frederikse 1997 [DIRS 103178]) were used as a source of information on properties of radioactive nuclei, such as the radioactive decay half-lives and branching fractions. These data are displayed in Table 6-23. 


\subsubsection{Building Shielding Factors}

Shielding factors presented in the NCRP Report No. 129 (NCRP 1999 [DIRS 155894]) are used in Section 6.6 to select values of building shielding factors. These values are displayed in Table 6-28.

These shielding factors are considered established fact and appropriate for use in this analysis for the following reasons. The NCRP was chartered by the U.S. Congress to collect, analyze, develop, and disseminate information and recommendations about radiation protection and measurements (NCRP 1997 [DIRS 160260], p. 226). The NCRP and ICRP (see Section 4.1.3) are independent non-governmental advisory bodies seeking to provide the quantitative scientific basis upon which radiation protection measures can be based. The NCRP work closely with international bodies, such as the ICRP, so that its recommendations reflect the consensus of leading scientific thinking. NCRP recommendations are considered for adoption by U.S. governmental organizations, including the NRC, the Public Health Service, the EPA, and state governments, to support specific advice, codes of practice, regulatory requirements, or other radiation protection activities.

The NCRP reviewed literature on the shielding by dwellings of radiation from soil contaminated with radionuclides. It then formulated recommendations of the shielding factor values in Report No. 129 (NCRP 1999 [DIRS 155894]). This assessment, and the accompanying values of building shielding factors, are appropriate for evaluating exposure to contaminated soil in the biosphere model because of the similarities in the type and geometry of the dwellings and source of contamination considered in that report and in the biosphere model.

\subsubsection{Other Sources of Direct Inputs in this Analysis}

Other sources of inputs considered to be established fact and used in this analysis include the rules at 10 CFR Part 63 [DIRS 156605] and 10 CFR Part 20 [DIRS 104787]. 10 CFR Part 63.312(d) [DIRS 156605] specifies the consumption rate of water (Section 6.4). 10 CFR Part 20 [DIRS 104787] was used to support development of dose conversion factor for radon decay products (Section 6.5.4). In addition, information from the CRC Handbook of Chemistry and Physics (Lide and Frederikse 1997 [DIRS 103178]) was used as a source of information on half-lives and branching fractions of some radionuclides (values are displayed in Table 6-23), to calculate distributions of exposure times (Section 6.3.2.2), and to determine the appropriate shielding factor for ${ }^{14} \mathrm{C}$ and ${ }^{210} \mathrm{Tl}$ (Section 6.6).

\subsection{CRITERIA}

Table 4-2 lists requirements from the Project Requirements Document (Canori and Leitner 2003 [DIRS 166275], Table 2-3) that are applicable to this analysis. These requirements are for compliance with applicable portions of 10 CFR Part 63 [DIRS 156605]. In addition to the requirements listed in Table 4-2, definition of terms in 10 CFR 63.2 [DIRS 156605] and description of concepts in 10 CFR 63.102 [DIRS 156605] that are relevant to biosphere modeling are also applicable to this analysis. 
Table 4-2. Requirements Applicable to This Analysis

\begin{tabular}{|l|l|c|}
\hline $\begin{array}{c}\text { Requirement } \\
\text { Number }\end{array}$ & \multicolumn{1}{c|}{ Requirement Title } & $\begin{array}{c}\text { Related } \\
\text { Regulation }\end{array}$ \\
\hline PRD-002/T-015 & Requirements for Performance Assessment & 10 CFR 63.114 \\
\hline PRD-002/T-026 & Required Characteristics of the Reference Biosphere & 10 CFR 63.305 \\
\hline PRD-002/T-028 & Required Characteristics of the Reasonably Maximally Exposed Individual & 10 CFR 63.312 \\
\hline
\end{tabular}

Source: Canori and Leitner 2003 (DIRS 166275), Table 2-3.

Listed below are the acceptance criteria from the Yucca Mountain Review Plan, Final Report (NRC 2003 [DIRS 163274]) that are applicable to this analysis. The list is based on meeting the requirements of 10 CFR 63.114, 10 CFR 63.305, and 10 CFR 63.312 [DIRS 156605] that relate in whole or in part to this analysis. See section 7.2 for a summary of where these criteria are addressed in this report.

\subsection{BIOSPHERE CHARACTERISTICS}

\subsection{System Description and Model Integration are Adequate}

14.1(3) Assumptions are consistent between the biosphere characteristics modeling and other abstractions. For example, the U.S. Department of Energy should ensure that the modeling of features, events, and processes, such as climate change, soil types, sorption coefficients, volcanic ash properties, and the physical and chemical properties of radionuclides are consistent with assumption in other total system performance assessment abstractions; and

\subsection{Data are Sufficient for Model Justification}

14.2(1) The parameter values used in the license application are adequately justified (e.g., behaviors and characteristics of the residents of the Town of Amargosa Valley, Nevada, characteristics of the reference biosphere, etc.) and consistent with the definition of the reasonably maximally exposed individual in 10 CFR Part 63. Adequate descriptions of how the data were used, interpreted, and appropriately synthesized into the parameters are provided; and

14.2(2) Data are sufficient to assess the degree to which features, events, and processes related to biosphere characteristics modeling have been characterized and incorporated in the abstraction. As specified in 10 CFR Part 63, the U.S. Department of Energy should demonstrate that features, events, and processes, which describe the biosphere, are consistent with present knowledge of conditions in the region, surrounding Yucca Mountain. As appropriate, the U.S. Department of Energy sensitivity and uncertainty analyses (including consideration of alternative conceptual models) are adequate for determining additional data needs, and evaluating whether additional data would provide new information that could invalidate prior modeling results and affect the sensitivity of the performance of the system to the parameter value or model.

\subsection{Data Uncertainty is Characterized and Propagated Through the Model Abstraction}

14.3(1) Models use parameter values, assumed ranges, probability distributions, and bounding assumptions that are technically defensible, reasonably account for uncertainties and variabilities, do not result in an under-representation of the risk estimate, and are consistent with the definition of the reasonably maximally exposed individual in 10 CFR Part 63;

14.3(2) The technical bases for the parameter values and ranges in the abstraction, such as consumption rates, plant and animal uptake factors, mass-loading factors, and biosphere dose conversion factors, are consistent with site characterization data, and are technically defensible;

14.3(3) Process-level models used to determine parameter values for the biosphere characteristics modeling are consistent with site characterization data, laboratory experiments, field measurements, and natural analog research; 
14.3(4) Uncertainty is adequately represented in parameter development for conceptual models and process-level models considered in developing the biosphere characteristics modeling, either through sensitivity analyses, conservative limits, or bounding values supported by data, as necessary. Correlations between input values are appropriately established in the total system performance assessment, and the implementation of the abstraction does not inappropriately bias results to a significant degree.

\subsection{CODES, STANDARDS, AND REGULATIONS}

No codes, standards, or regulations other than those identified in the Project Requirements Document (Canori and Leitner 2003 [DIRS 166275], Table 2-3) and determined to be applicable (Table 4-2) were used in this analysis. 


\section{ASSUMPTIONS}

In Section 6.3.1, two assumptions are used to estimate the proportion of the adult population in the Amargosa Valley that could be classified into four population groups (population groups are described in Section 6.2).

\subsection{PROPORTION OF POPULATION-COMMUTERS}

For the groundwater exposure scenario, people who travel 10 minutes or more (one way) to work are classified as commuters and spend their working hours outside of the potentially contaminated area. For the volcanic ash exposure scenario, people who travel 35 minutes or more (one way) to work are classified as commuters.

This assumption is based on 10 CFR Part 63 [DIRS 156605], which defines the location of the receptor and states that the RMEI should have a lifestyle representative of the people who reside in Amargosa Valley (10 CFR 63.312 [DIRS 156605]; see also Section 6.2) and the predicted depth of ash in northern Amargosa Valley after a volcanic eruption at Yucca Mountain.

Groundwater Exposure Scenario-For the groundwater exposure scenario, the receptor would only receive a dose from inhalation of, or exposure to, contaminated soil while commuting or working within areas where contaminated groundwater is used to irrigate crops or gardens. For this scenario, the amount of time it would take to drive out of the area contaminated by use of groundwater is determined based on the current conditions in the agricultural region of Amargosa Valley. That region is a maximum of about $13 \mathrm{~km}$ wide (along Farm Road); therefore, residents can leave the area where irrigated fields occur in less than 10 minutes of driving on the paved roads in the area.

Volcanic Ash Exposure Scenario-For this scenario, the receptor could receive a radiation dose from ash deposited on the ground surface in residential and work environments and from ash redistributed into those environments from aeolian and fluvial processes (calculation of dose during the volcanic eruption is addressed outside of the biosphere model and is not discussed here). Therefore, the amount of time required to travel out of the contaminated area is based on information about the distribution of ash following a volcanic eruption at Yucca Mountain.

The amount of ash initially deposited at a location would depend primarily on characteristics of the volcano, wind direction, and distance from Yucca Mountain. Ash depths $18 \mathrm{~km}$ downwind from Yucca Mountain were predicted to range from 0.07 to $55 \mathrm{~cm}$ (based on 100 realizations of the ASHPLUME model; BSC 2004 [DIRS 170026], Table 6-4; with ash thickness calculated from ash concentration as described in the footnote to Table 6-5). About 35 percent of predicted depths were less than $1 \mathrm{~cm}, 75$ percent were less than $5 \mathrm{~cm}$, and 90 percent were less than $15 \mathrm{~cm}$. Ash depths at the location of the RMEI (18 km south of Yucca Mountain) would be about 2 orders of magnitude or more lower under normal, variable wind conditions (CRWMS M\&O 2000 [DIRS 153246], Section 3.10.5.1 and Figure 3.10-14) because the wind at Yucca Mountain blows to the south infrequently (BSC 2004 [DIRS 170026], Figure 8-1). Based on this information, it is likely that at least a thin layer of ash would be deposited throughout most or all of the Amargosa Valley and at many work areas on the Nevada Test Site. It is much less likely 
that ash would be deposited at more distant population and employment centers to the south (Pahrump), east (Las Vegas), and west (Beatty).

Over time, some ash initially deposited at or near Yucca Mountain would be washed into the Amargosa Valley via Fortymile Wash. Ash may also be redistributed into the upper reaches of the Amargosa River near Beatty, Nevada, via Beatty Wash and other drainages that flow west from Yucca Mountain. Because they are outside the watersheds where substantial amounts of ash would be deposited initially, large amounts of ash probably would not be redistributed into Las Vegas and Pahrump.

For the volcanic ash exposure scenario, it is assumed that, on average, people who commute to work less than 35 minutes (one way) remain in the contaminated area. Within 35 minutes, a person living in northern Amargosa Valley could travel to work sites in the Amargosa Valley, Beatty, and much of the Nevada Test Site. They probably could not travel to Pahrump or to other employment centers in Clark County (e.g., Indian Springs, Las Vegas) in only 35 minutes.

The minimum value of the distribution of the proportion of the population classified as commuters is calculated as the average minus two standard errors (in contrast to \pm one standard error for other population groups) to account for uncertainty in the distribution of ash and the travel time required to leave contaminated areas (Section 6.3.1).

\subsection{PROPORTION OF POPULATION-LOCAL OUTDOOR WORKERS}

For both exposure scenarios, all residents working in agriculture, 25 percent of those working in construction, 10 percent of those working in the utilities industry, and 10 percent of miners are classified as local outdoor workers who spend their working hours outdoors in the potentially contaminated area. To account for uncertainty in the distribution of ash, the upper bound of the distribution of local outdoor workers is calculated as two times the standard error of the mean. All other distribution tails for both scenarios are calculated as one times the standard error of the mean.

This assumption is based on information from the Bureau of the Census (2002 [DIRS 159728], Table P49) on the number of people working in various industries (Table 6-4). The population group "local outdoor workers" includes people who work outdoors and disturb (and therefore resuspend) contaminated soil. Because motor vehicle operators and others working in the transportation industry spend most of their time in enclosed cabs, they would not be exposed to substantial amounts of contaminated soil, and they are not considered local outdoor workers.

All residents of the Amargosa Valley who work in agriculture, forestry, or fisheries are assumed to work outdoors in that valley.

Many people in the construction and utilities industries also work outdoors. However, because many workers in Amargosa Valley have a long travel time to work (e.g., 20 percent had a travel time to work of more than 35 minutes in 2000; Table 6-3), and because there are few industries in Amargosa Valley that require construction and utility workers (Rasmuson 2004 [DIRS 169506]), it is likely that only a few of these people work in the Amargosa Valley and conduct soil-disturbing activities. To account for these local workers, 25 percent of construction 
workers and 10 percent of utility workers are assumed to spend their work time outdoors in the Amargosa Valley. Because of the small number of workers in these industries, estimates of exposure times are insensitive to these percentages.

One-hundred and nineteen people in Amargosa Valley are employed in the mining industry (Table 6-4). Of these, about 58 (Bureau of the Census 2002 [DIRS 159728], Table P50) list their occupation as extraction workers (i.e., miners). Many of these miners probably work in hard-rock or clay mines around Beatty (Nevada Department of Minerals et al. 1991 [DIRS 160176], Section VI; Driesner and Coyner 2001 [DIRS 160175], Section VI]). In 1990, when gold and silver prices were relatively high (Driesner and Coyner 2001 [DIRS 160175], p. 23), six of eight operational mines in southern Nye County were located around Beatty. The mines employed more than 400 people, with about 75 percent working at the Bullfrog Mine. The only mines in or near the Amargosa Valley in 1990 were a clay mine near the California border, employing 54 people, and a cinder mine at the Lathrop Wells Cone (at the north end of the Amargosa Valley), employing two people (Nevada Department of Minerals et al. 1991 [DIRS 160176], Section VI). Because the Bullfrog Mine closed during the 1990s due to exhaustion of profitable ores and lower gold prices (Driesner and Coyner 2001 [DIRS 160175], p. 23), few mines were operating in the region in 2000. According to Driesner and Coyner (2001 [DIRS 160175], Section VI), there were two operating mines near Beatty in 2000 (employing about 50 people) and a clay mine in southern Amargosa Valley (employing 33 people). Davis (2001 [DIRS 160096], p. 59) also lists the cinder mine at the Lathrop Wells Cone as operational and employing seven people in 2000.

The only miners likely to work in or near an area potentially contaminated by water from a well or a substantial amount of volcanic ash are those working at the cinder mine or at temporary sand and gravel operations that could be developed in the northern part of the valley. The specialty clays mined in the Amargosa Valley are found only in the lacustrine sediments at the southern end of the valley (Castor 2001 [DIRS 160095], pp. 40 and 42). Even if ash were to fall at those clay mines or at hard-rock mines in the region, miners there would be exposed for a very short time because the ash would have to be removed before subsurface clay or rock could be mined. Estimates of activity budgets are relatively sensitive to the percentage of miners because miners are a substantial portion of the work force. To ensure that the number of miners working in a potentially contaminated area is not underestimated, it is assumed that 10 percent of the Amargosa Valley residents employed in the mining industry work outdoors in contaminated areas.

This assumption is intended for use in the groundwater and volcanic ash exposure scenarios. However, there is a small possibility that contaminated ash would be deposited at some mines and other outdoor work locations in southern Amargosa Valley, Beatty, and elsewhere. To account for uncertainty in the distribution of ash and the subsequent exposure to additional miners and other outdoor workers following a volcanic eruption, the upper bound of the distribution of local outdoor workers is calculated as two times the standard error of the mean, as described in Section 6.3.1. 


\section{INTENTIONALLY LEFT BLANK}




\section{SCIENTIFIC ANALYSIS DISCUSSION}

The objective of this analysis is to develop values for the parameters used in the ERMYN that represent characteristics of the human receptor. The receptor considered in this analysis, the RMEI, is defined in Section 6.1. The methods and parameters used in the biosphere model to evaluate receptor exposure are presented in Section 6.2.

Characteristics of the RMEI are based on regulations (10 CFR Part 63 [DIRS 156605]; see also Section 6.1) and on the range of conditions typical of the environment and population in the Amargosa Valley. Local lifestyle and dietary characteristics of the RMEI are considered in this report. Lifestyle parameters are discussed in Section 6.3 and Section 6.6, and include the type and location of employment and the associated population proportions, land use, activity budgets (i.e., amount of time spent conducting activities and the location where those activities occur), recreation, and characteristics of dwellings. Lifestyle characteristics are considered in the biosphere model for the parameters exposure time, fraction of houses with evaporative coolers, evaporative cooler use factor, inadvertent soil ingestion rate, and building shielding factor.

Dietary parameters are discussed in Section 6.4. Dietary characteristics include the consumption rate of contaminated food and water. These characteristics are considered in the model parameters for consumption rate of water and consumption rates of locally produced leafy vegetables, other vegetables, fruit, grain, meat, poultry, milk, eggs, and fish.

This analysis report also develops values for breathing rates, which are related to the physiology of the receptor (Section 6.3.3); describes the dosimetric methods used to convert internal and external exposure of the receptor to radiation doses; and selects dose coefficients for internal and external exposure (Section 6.5) and building shielding factors (Section 6.6).

\subsection{DEFINITION OF THE RECEPTOR}

In 2001, the EPA promulgated Public Health and Environmental Radiation Protection Standards for Yucca Mountain, Nevada (40 CFR 197 [DIRS 155238]). The EPA rule includes an Individual-Protection Standard (40 CFR 197.20 and 197.21 [DIRS 155238]) for the performance of the repository, expressed as the annual dose limit to the RMEI. The NRC incorporated these standards into licensing regulations in Disposal of High-level Radioactive Wastes in a Geologic Repository at Yucca Mountain, Nevada (10 CFR Part 63 [DIRS 156605]), consistent with requirements of the Energy Policy Act of 1992.

Postclosure performance objectives include the requirement that radiological exposure to the RMEI are within specified limits (10 CFR 63.113 [DIRS 156605]). The limits for the individual protection standard, as in the EPA rule, are expressed in terms of an annual dose that includes all potential pathways of radionuclide transport and exposure (10 CFR 63.311 [DIRS 156605]). 
The RMEI is a hypothetical receptor who meets the following criteria (10 CFR 63.312 [DIRS 156605]):

- Lives in the accessible environment above the highest concentration of radionuclides in the plume of contamination

- Has a diet and living style representative of people who now reside in the Town of Amargosa Valley, Nevada. DOE must use projections based on surveys of the people residing in the Town of Amargosa Valley, Nevada, to determine their current diets and living styles and use the mean values of these factors in the assessments conducted for 10 CFR 63.311 and 10 CFR 63.321 (DIRS 156605)

- Uses well water with average concentrations of radionuclides based on an annual water demand of 3,000 acre-feet

- Drinks 2 liters of water per day from wells drilled into the groundwater from a point above the highest concentration of radionuclides in the plume of contamination

- Is an adult with metabolic and physiological considerations consistent with present knowledge of adults.

The required characteristics of the RMEI include living in the accessible environment above the highest concentration of radionuclides in the plume of contamination (10 CFR 63.312(a) [DIRS 156605]). The location within the accessible environment with the highest concentrations likely would be above the contaminated groundwater plume at or near the southern edge of the controlled area (i.e., as close to Yucca Mountain as is accessible). The southern edge of the controlled area can extend no farther south than $36^{\circ} 40^{\prime} 13.6661 "$ North latitude (10 CFR 63.302, definition of Controlled Area (1)(i) [DIRS 156605]), which is north of Highway 95 near the southern boundary of the Nevada Test Site. The approximate location of the contaminated plume has been predicted to be below Fortymile Wash (DOE 2001 [DIRS 153849], Figure 4-147). The exact location of the RMEI within this general area is not important for the parameters considered in this analysis, because the parameter values are independent of the exact location.

Regulation 10 CFR 63.312(b) (DIRS 156605) refers to the "Town of Amargosa Valley"; however, there is no legally defined location associated with that name. The most applicable legally defined region is the Nye County unincorporated town and taxing district of Amargosa Valley (Figure 6-1).

To meet the requirement in 10 CFR 63.312(b) (DIRS 156605) that mean values for factors related to dietary and lifestyle characteristics are used, all parameter distributions developed in this report are based on mean values for the population under consideration, and variation is calculated based on the standard error of the mean. Thus, the RMEI is a hypothetical composite individual with dietary and lifestyle characteristics represented by mean values of the people who reside in the unincorporated town of Amargosa Valley. 
To address other requirements of 10 CFR 63.312(b) (DIRS 156605), information from surveys of the people living in Amargosa Valley were used in this analysis to determine average values of current diets and living styles. A regional survey was conducted in 1997 to determine the frequency at which people in the Amargosa Valley consume locally produced food and to quantify other lifestyle characteristics (e.g., use of evaporative coolers) (DOE 1997 [DIRS 100332]). Data from survey respondents having a telephone prefix of 372 were used in this analysis. This prefix covered the Amargosa Valley, Lathrop Wells, Ash Meadows, and Crystal areas (DOE 1997 [DIRS 100332], p. 3). Of 187 responses included in the analysis, two were from people who stated they lived in Crystal, one was from someone who stated she lived in Ash Meadows, and the remainder were from people who stated that they lived in Amargosa Valley (Appendix A). Thus, the information used in this analysis from that survey is representative of the people that reside in the unincorporated town of Amargosa Valley (Figure 6-1), as required by 10 CFR 63.312(b) (DIRS 156605).

Survey data from the 2000 census (Bureau of the Census 2002 [DIRS 159728]) were used to determine the proportion of the Amargosa Valley population in four population groups (Section 6.3.1) and to estimate the average amount of time the receptor spends in five environments (Section 6.3.2). Data from the Amargosa Valley census county division were used in this analysis. This area (Figure 6-1, Tract 980300 BG3) includes all residents of the unincorporated town of Amargosa Valley except for those living in about 10 residences in the western part of Crystal. Data from those residences could not be used because information about all people living in Crystal was included by the Census Bureau in the Pahrump census county division (Figure 6-1). Because the Amargosa Valley census county division includes almost all residents of the unincorporated town of Amargosa Valley, including those living in areas most likely to be affected by the Yucca Mountain repository, the data are a valid representation of the lifestyle characteristics of the people who now reside in the town of Amargosa Valley, Nevada.

The RMEI is defined as an adult (10 CFR 63.312(e) [DIRS 156605]). For dose assessments, an adult is usually defined as an individual 18 or more years old (10 CFR 20.1003 [DIRS 104787]). Information on people 18 or more years old was used throughout this analysis with the following two exceptions. The Bureau of Census (2002 [DIRS 159728]) reports some data used in this analysis (e.g., number of hours worked per year; Tables 6-2 and 6-6) for residents 16 or more years old. Because there is no way to separate census information about 16- and 17-year-olds from information on older residents, some analyses in Section 6.3.1 and 6.3.2 were derived from residents 16 or more years old. This has little influence on the results of this analysis because only an estimated 3.7 percent (32 of 862; Table 6-10) of Amargosa Valley residents 16 or more years old were 16 or 17 years old. Average daily intake and frequency of consumption used in Section 6.4.2 (USDA 2000 [DIRS 154158]) to calculate consumption rates of locally produced foods were based on national survey results for males and females 20 or more years old. This was done because survey information for persons 18 and 19 years old could not be separated from younger age groups. This has little influence on the results of this analysis because 18- and 19-year-olds only comprised 4.7 percent (39 of 830; Table 6-10) of the Amargosa Valley residents 18 or older in 2000.

The characteristics of the RMEI and the individual protection standard of $0.15 \mathrm{mSv} / \mathrm{year}$ (15 mrem/year) (10 CFR 63.311 [DIRS 156605]) are considered protective of the general population. The general population includes individuals who are represented by the RMEI and 
all other individuals residing in the Yucca Mountain area. Because the community represented by the RMEI will have a higher estimated dose than the highest exposed individual who does not live in that community, an individual dose limit for the RMEI is protective of all individuals (66 FR 55732 [DIRS 156671], p. 55750). Because the location of the RMEI is directly above the path of the contamination plume and because the diet and lifestyle are representative of people living in the Amargosa Valley, the estimated dose to the RMEI bounds any doses received by other individuals in the population.

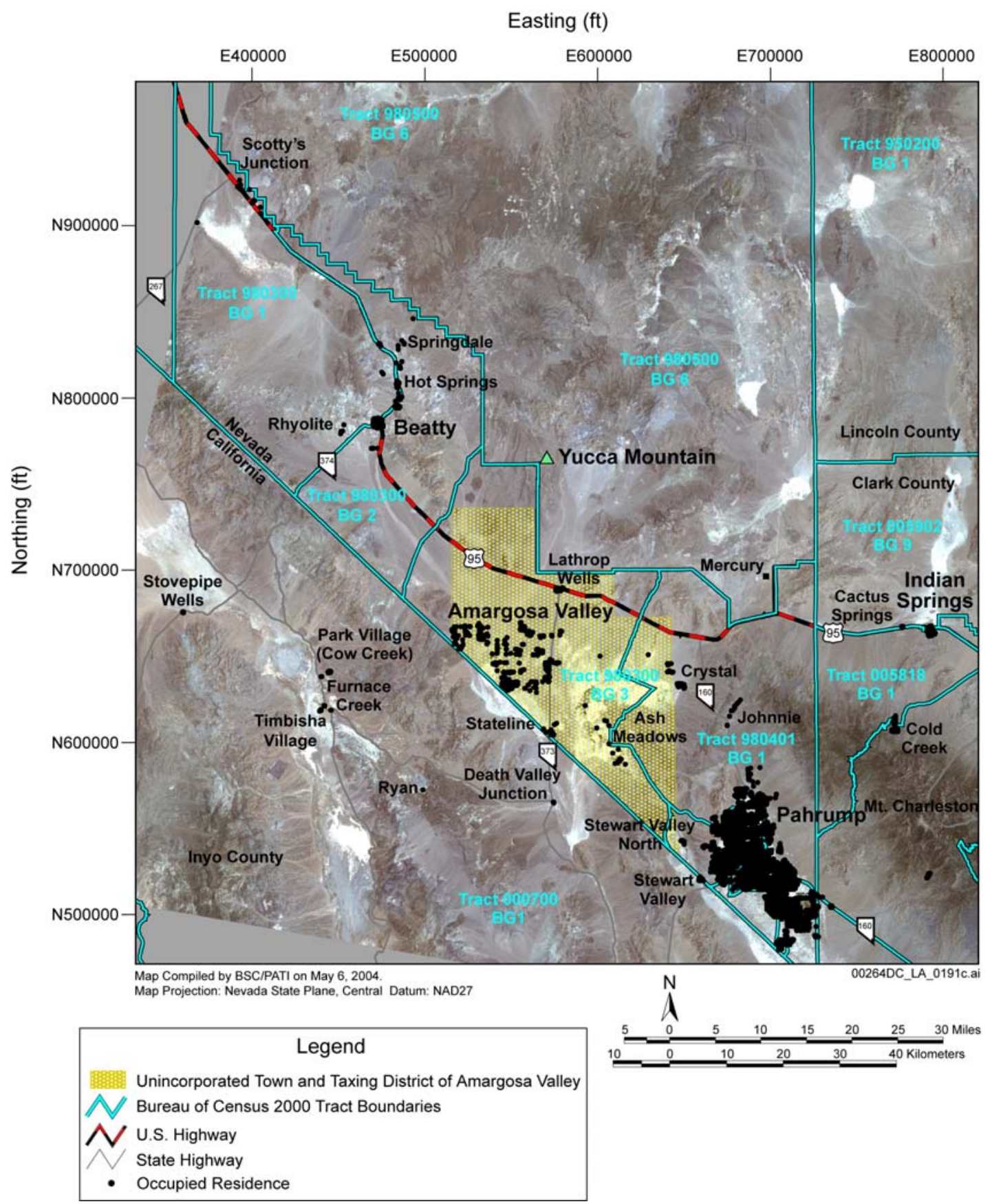

Source: BSC 2003 [DIRS 168723], Figure 1.

Figure 6-1. South Central Nevada Census Geography 


\subsection{METHODS FOR EVALUATING RECEPTOR RADIATION EXPOSURE, INTAKES, AND DOSES}

A person living in a contaminated environment can become exposed to radiation via many exposure pathways. The exposure pathways originate in the contaminated environmental medium, such as soil, air, or water. Contact with these media results in external exposure or intake of radionuclides by inhalation or ingestion. Exposure pathways included in the biosphere model, and the associated parameters related to characteristics of the receptor, are shown in Table 6-1. The exposure pathways for the volcanic ash exposure scenario are the same as those for the groundwater exposure scenario, except for the omission of pathways directly associated with contaminated water (e.g., water intake, consumption of freshwater fish, inhalation of aerosols generated by evaporative coolers) or associated with radionuclides that are not considered for volcanic releases $\left({ }^{14} \mathrm{C}\right)$.

Methods for calculating annual doses to the RMEI from the three major radiation exposure pathways (external exposure, inhalation, and ingestion) are described in this section. To estimate radiation doses, the biosphere model calculates radionuclide concentrations in the environmental media. Then the external exposure or radionuclide intake is evaluated considering the dietary and lifestyle characteristics of the receptor. The conversion of radionuclide intake or external exposure to dose is accomplished using DCFs or dose coefficients.

Within the biosphere model, BDCFs (which differ from DCFs, as defined in Section 6.5), rather than total doses, are calculated. BDCFs are numerically equal to the dose per unit concentration of a radionuclide in a source media (e.g., groundwater or ash). These conversion factors are then used in the TSPA (where the concentrations of radionuclides in the source media are estimated) to calculate total dose. Therefore, in this report, descriptions and references to dose calculations in the biosphere model infer that the calculation uses a unit concentration of radionuclides in a medium.

To account for variation and uncertainty in the characteristics of the RMEI and concentrations of radionuclides in the biosphere, the ERMYN uses a microenvironmental modeling approach to calculate inhalation and external exposure doses. For microenvironmental models, the total exposure environment (i.e., the biosphere) is divided into segments, or environments, with different concentrations of contaminants. The contaminant concentration, time spent exposed to the contaminant, and intake rate or exposure factor (e.g., breathing rate, shielding factor) are determined for each environment; the total dose is calculated as the sum of the dose within all environments (Mage 1985 [DIRS 162465], pp. 409 to 410). Micro-environmental models are commonly used to evaluate exposure to particulate matter and other contaminants (Duan 1982 [DIRS 162466]; Mage 1985 [DIRS 162465]; Klepeis 1999 [DIRS 160094]).

In the ERMYN model, the biosphere is divided into five environments. These mutually exclusive environments represent the behavioral and environmental combinations for which people may receive substantially different rates of exposure via inhalation or external exposure.

Away from Potentially Contaminated Area-This category includes time spent away from areas contaminated by groundwater or volcanic ash, including time spent working and commuting to work by people who work outside the contaminated areas. 
Table 6-1. Biosphere Model Exposure Pathways and Associated Parameters Related to Receptor Characteristics

\begin{tabular}{|c|c|c|c|}
\hline $\begin{array}{l}\text { Environmental } \\
\text { Medium }\end{array}$ & $\begin{array}{l}\text { Exposure } \\
\text { Mode }\end{array}$ & Exposure Pathways $^{a}$ & $\begin{array}{l}\text { Associated Parameters Related to the } \\
\text { Receptor Characteristics }\end{array}$ \\
\hline WATER & Ingestion & Water intake * & $\begin{array}{l}\text { Consumption rate of water } \\
\text { DCFs for ingestion }\end{array}$ \\
\hline \multirow[b]{2}{*}{ SOIL } & Ingestion & Inadvertent soil ingestion & $\begin{array}{l}\text { Inadvertent soil ingestion rate } \\
\text { DCFs for ingestion }\end{array}$ \\
\hline & External & External radiation exposure & $\begin{array}{l}\text { Population proportion } \\
\text { Exposure time } \\
\text { Building shielding factor } \\
\text { Dose coefficient for exposure to contaminated } \\
\text { ground surface } \\
\text { Dose coefficient for exposure to soil } \\
\text { contaminated to an infinite depth }\end{array}$ \\
\hline AIR & Inhalation & $\begin{array}{l}\text { Breathing of airborne } \\
\text { particulates } \\
\text { Breathing of gases }\left({ }^{222} \mathrm{Rn} \text { and }\right. \\
\text { decay products) } \\
\text { Breathing of gases }\left({ }^{14} \mathrm{C}\right)^{\star} \\
\text { Breathing of aerosols from } \\
\text { evaporative coolers }\end{array}$ & $\begin{array}{l}\text { Population proportion } \\
\text { Exposure time } \\
\text { Breathing rate } \\
\text { Fraction of houses with evaporative coolers } \\
\text { Evaporative cooler use factor } \\
\text { DCFs for inhalation } \\
\text { DCF for inhalation of radon decay products }\end{array}$ \\
\hline PLANTS & Ingestion & $\begin{array}{l}\text { Consumption of locally } \\
\text { produced crops: } \\
\text { Leafy vegetables } \\
\text { Other vegetables } \\
\text { Fruit } \\
\text { Grain }\end{array}$ & $\begin{array}{l}\text { Consumption rate of locally produced crops } \\
\text { DCFs for ingestion }\end{array}$ \\
\hline ANIMALS & Ingestion & $\begin{array}{l}\text { Consumption of locally } \\
\text { produced animal products: } \\
\text { Meat } \\
\text { Poultry } \\
\text { Milk } \\
\text { Eggs }\end{array}$ & $\begin{array}{l}\text { Consumption rate of locally produced animal } \\
\text { products } \\
\text { DCFs for ingestion }\end{array}$ \\
\hline $\begin{array}{l}\text { AQUATIC } \\
\text { ORGANISMS }\end{array}$ & Ingestion & $\begin{array}{l}\text { Consumption of locally } \\
\text { produced freshwater fish* }\end{array}$ & $\begin{array}{l}\text { Consumption rate of locally produced fish } \\
\text { DCFs for ingestion }\end{array}$ \\
\hline
\end{tabular}

Source: Based on descriptions of exposure pathways in the Biosphere Model Report (BSC 2004 [DIRS 169460], Section 6.3).

${ }^{a}$ All pathways are the same for the groundwater and volcanic ash exposure scenarios except those marked with an asterisk, which are not included in the volcanic ash exposure scenario.

$\mathrm{DCF}=$ dose conversion factor 
Active Outdoors-Time spent active outdoors includes time spent outdoors in contaminated areas conducting activities that resuspend soil. This includes conducting dust-generating activities while working (e.g., plowing, excavating, and livestock operations) and recreating (e.g., gardening, landscaping, and riding horses or motorbikes) outdoors. Because dust concentrations decrease rapidly after dust-disturbing activities cease (e.g., Pinnick et al. 1985 [DIRS 159577], pp. 103 to 104), this category is limited to the time when the activities are occurring.

Inactive Outdoors-This category represents the time spent commuting within contaminated areas and time spent outdoors in the contaminated area conducting activities that do not resuspend soil (e.g., sitting, swimming, walking, barbecuing, and equipment maintenance). Commuting time is included in this category, because major roads in the Amargosa Valley are paved.

Asleep Indoors-This category includes time spent sleeping indoors within contaminated areas.

Active Indoors-This category includes time spent awake, indoors within contaminated areas, including work time. In the model, this is calculated as the remainder of the day not spent in the other four environments.

To account for variation and uncertainty in the amount of time the receptor spends in these environments, the model considers four mutually exclusive population groups (Section 6.3.1). The exposure times per environment for the RMEI are calculated as the weighted average of the exposure times per environment for all population groups (e.g., Equation 6.2-3). These groups represent the range of behaviors that most influence the amount of time people would be exposed to radionuclides via inhalation of resuspended soil, use of evaporative coolers, and external exposure. Variation among individuals in these exposure pathways is influenced primarily by the amount of time spent indoors and outdoors within contaminated areas and spent away from contaminated areas. For adults, variation among these time factors primarily is a function of occupational characteristics. People working out of a contaminated area generally would experience less exposure than people who remain within the area, and people who work outdoors would be exposed at a different level than those who remain indoors. Therefore, the categories are based on work location and type of occupation. Estimates of the proportion of the adult population of the Amargosa Valley in each group are given in Section 6.3.1.

Non-Workers-Residents who are unemployed or not in the labor force, including retired persons.

Commuters-Residents who work in uncontaminated areas.

Local Outdoor Workers-Residents who work outdoors, disturb and resuspend contaminated soil.

Local Indoor Workers-Residents who work indoors (or outdoors in enclosed vehicles) in contaminated areas. The proportion of the population in this group is calculated as the proportion not in the other groups. 


\subsubsection{Evaluation of External Exposure}

Doses received from external sources of radiation originate from radionuclides in the soil, air, and water. For external exposure, radiation emitters are external to the human body. Therefore, the exposure continues only as long as a person is in the immediate vicinity of, or in direct contact with, the contaminated medium, such as soil, air, or water. The doses from external exposure can be evaluated using radionuclide media concentrations and the duration of exposure to these media in combination with dose coefficients for external exposure to photons and electrons emitted by radionuclides distributed in the contaminated media.

The annual individual dose to a receptor from external exposure to primary radionuclide $i$ in contaminated soil may include contributions from other primary radionuclides formed in the soil as a result of radioactive decay of radionuclide $i$. The combined dose is estimated using the expression in Equation 6.2-1 (BSC 2004 [DIRS 169460], Section 6.4.7.1):

$$
D_{\text {ext }, i}=\sum_{l} D_{e x t, l}=\sum_{l} E D C i_{s o i l, l} \frac{C s_{l}}{d}\left[\sum_{n} f_{e x t, l, n}\left(\sum_{m} P P_{m}\left(3600 \times t_{n, m}\right)\right)\right]
$$

where

$$
\begin{aligned}
& D_{\text {ext }, i}=\text { annual dose from external exposure to primary radionuclide } i \text { in soil (Sv/yr) } \\
& D_{\text {ext }, l} \quad=\text { dose from external exposure to radionuclide } l \text { in a decay chain of a primary } \\
& \text { radionuclide } i(\mathrm{~Sv} / \mathrm{yr}) \\
& l \quad=\text { index of radionuclide in a decay chain; } l=0 \text { for primary radionuclide } \\
& E D C i_{\text {soil }, 1}=\text { effective dose coefficient for exposure to soil contaminated to an infinite } \\
& \text { depth for a radionuclide } l \text { in a decay chain of a primary radionuclide } i \text { (Sv/s } \\
& \text { per } \mathrm{Bq} / \mathrm{m}^{3} \text { ) } \\
& \mathrm{Cs}_{l} \quad=\text { saturation activity concentration in surface soil for a radionuclide } l \text { in a } \\
& \text { decay chain of a primary radionuclide } i\left(\mathrm{~Bq} / \mathrm{m}^{2}\right) \\
& d \quad=\text { depth of surface soil }(\mathrm{m})
\end{aligned}
$$

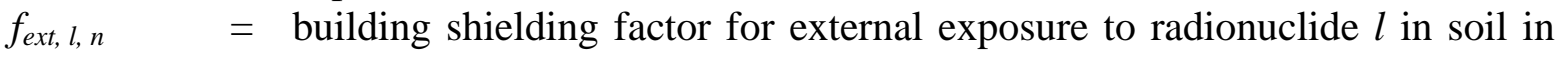

$$
\begin{aligned}
& \text { environment } n \text { (dimensionless) } \\
& n=\text { environment index; } n=1 \text { for active outdoors, } 2 \text { for inactive outdoors, } 3 \text { for } \\
& \text { active indoors, } 4 \text { for asleep indoors, and } 5 \text { for away from the contaminated } \\
& \text { area } \\
& m \quad=\text { population group index; } m=1 \text { for commuters, } 2 \text { for local outdoor workers, } \\
& 3 \text { for local indoor workers, and } 4 \text { for non-workers } \\
& \mathrm{PP}_{m} \quad=\text { population proportion (fraction of total population in population group } m \text { ) } \\
& t_{n, m} \quad=\text { exposure time (number of hours a population group } m \text { spends in the } \\
& \text { environment } n \text { ) (hr/yr) } \\
& 3600=\text { unit conversion factor, } 3600 \mathrm{~s} / \mathrm{hr} \text {. }
\end{aligned}
$$

This analysis develops values for the dose coefficients for individual radionuclides that are used to develop the effective dose coefficients for exposure to contaminated soil, EDCF $F_{\text {soil, } l}$

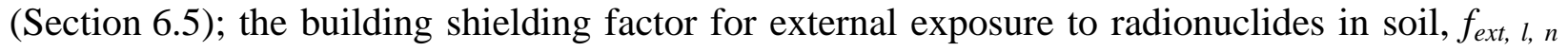
(Section 6.6); the amount of time population groups spend in defined environments, $t \mathrm{n}, \mathrm{m}$ 
(Section 6.3); and the fraction of total population in specified population groups, $P P_{m}$ (Section 6.3).

\subsubsection{Evaluation of Inhalation Exposure}

External exposure, described in the previous section, results from emissions that arise outside the human body. This is in contrast to the intake of radionuclides by inhalation or ingestion, for which radiation is emitted inside the body and the exposure continues following the intake for as long as the radionuclides remain in the body. The inhalation dose is caused by inhalation of contaminated air. Three mechanisms of air contamination were included in the biosphere model: resuspension of contaminated soil, the use of evaporative coolers, and gaseous emission from soil (which includes exhalation of ${ }^{222} \mathrm{Rn}$, and ${ }^{14} \mathrm{C}$ from soil). The total inhalation dose is the sum of inhalation doses resulting from these processes (BSC 2004 [DIRS 169460], Section 6.4.8) such that

$$
D_{i n h, i}=D_{i n h, p, i}+D_{i n h, e, i}+D_{i n h, g, i}
$$

where

$$
\begin{aligned}
D_{i n h, i}= & \text { annual dose from inhalation exposure to radionuclide } i(\mathrm{~Sv} / \mathrm{yr}) \\
D_{\text {inh, }, i}= & \text { annual dose from inhalation exposure to radionuclide } i \text { in resuspended } \\
& \text { particles }(\mathrm{Sv} / \mathrm{yr}) \\
D_{\text {inh, }, i}= & \begin{array}{l}
\text { annual dose from inhalation exposure to radionuclide } i \text { in air resulting from } \\
\text { operation of evaporative cooler }(\mathrm{Sv} / \mathrm{yr})
\end{array} \\
D_{\text {inh, }, i}= & \begin{array}{l}
\text { annual dose from inhalation exposure to radionuclides in air resulting from } \\
\text { gaseous emission of radionuclide } i \text { from soil }(\mathrm{Sv} / \mathrm{yr}) .
\end{array}
\end{aligned}
$$

The last dose component (Equation 6.2-2) applies only to the inhalation of ${ }^{222} \mathrm{Rn}$ decay products, and ${ }^{14} \mathrm{C}$.

\subsubsection{Inhalation of Airborne Particulates}

The annual dose to a receptor from inhalation exposure to primary radionuclide $i$ in resuspended particles includes all radionuclides $(l)$ in the decay chain of primary radionuclide $i$. The combined dose is estimated (BSC 2004 [DIRS 169460], Section 6.4.8.1) in Equation 6.2-3 as

$$
D_{i n h, p, i}=\sum_{l} D_{i n h, p, l}=\sum_{l} E D C F_{i n h, l}\left[\sum_{n} C a_{h, l, n} B R_{n} \sum_{m}\left(P P_{m} t_{n, m}\right)\right]
$$

where

$$
\begin{aligned}
D_{\text {inh, }, i}= & \text { annual dose from inhalation exposure to primary radionuclide } i \text { in } \\
& \text { resuspended particles }(\mathrm{Sv} / \mathrm{yr}) \\
D_{\text {inh, }, l}= & \text { annual dose from inhalation exposure to radionuclide } l \text { in a decay chain of } \\
& \text { primary radionuclide } i \text { in resuspended particles }(\mathrm{Sv} / \mathrm{yr})
\end{aligned}
$$


$l=$ Radionuclide index for a decay chain, $l=0$ for primary radionuclide, 1 for the $1^{\text {st }}$ decay product, 2 for the $2^{\text {nd }}$ decay product

$E D C F_{\text {inh, } l}=$ effective DCF for inhalation of radionuclide $l$ in a decay chain of primary radionuclide $i(\mathrm{~Sv} / \mathrm{Bq})$

$n \quad=$ Environment index; $n=1$ for active outdoors, 2 for inactive outdoors, 3 for active indoors, 4 for asleep indoors, and 5 for away from the contaminated area

$C a_{h, l, n} \quad=$ activity concentration of radionuclide $l$ in a decay chain of primary radionuclide $i$ in air for human $(h)$ environment $n\left(\mathrm{~Bq} / \mathrm{m}^{3}\right)$

$B R_{n} \quad=$ breathing rate for environment $n\left(\mathrm{~m}^{3} / \mathrm{hr}\right)$

$m \quad=$ population group index; $m=1$ for commuters, 2 for local outdoor workers, 3 for local indoor workers, and 4 for non-workers

$\mathrm{PP}_{\mathrm{m}} \quad=$ population proportion (fraction of total population in population group $\mathrm{m}$ )

$t_{n, m} \quad=$ exposure time (number of hours a population group $m$ spends in environment $n$ ) (hr/yr).

This analysis develops values for the inhalation DCFs for individual radionuclides that are used to develop the effective DCFs for inhalation, $E D C F_{\text {inh, }}$ l (Section 6.5); the environment-dependent breathing rate, $B R_{n}$ (Section 6.3); the amount of time population groups spend in defined environments, $t_{n, m}$ (Section 6.3); and the fraction of total population in specified population groups, $P P_{m}$ (Section 6.3).

\subsubsection{Inhalation of Aerosols Produced by Evaporative Coolers}

The inhalation dose attributable to the operation of evaporative coolers is estimated (BSC 2004 [DIRS 169460], Section 6.4.8.2) in Equation 6.2-4 as

$$
D_{\text {inh }, e, i}=E D C F_{\text {inh }, i} C a_{e, i} f_{\text {cooler }} f_{\text {use }} \sum_{n=3}^{4} B R_{n}\left(\sum_{m} P P_{m} t_{n, m}\right)
$$

where

$$
\begin{array}{ll}
D_{\text {inh, }, i}= & \text { annual dose from inhalation of primary radionuclide } i \text { from evaporative } \\
& \text { cooler operation }(\mathrm{Sv} / \mathrm{yr}) \\
E D C F_{\text {inh }, i}= & \text { effective } \mathrm{DCF} \text { for inhalation of radionuclide } i(\mathrm{~Sv} / \mathrm{Bq}) \\
C a_{e, i} & \text { activity concentration of radionuclide } i \text { in indoor air attributable to the } \\
& \text { evaporative cooler operation }\left(\mathrm{Bq} / \mathrm{m}^{3}\right) \\
f_{\text {cooler }} & \text { fraction of houses with evaporative coolers (dimensionless) } \\
f_{\text {use }} & \text { annual evaporative cooler use factor (dimensionless). }
\end{array}
$$

This analysis develops values for the inhalation DCFs for individual radionuclides that are used to develop the effective DCFs for inhalation, $E D C F_{i n h}, i$ (Section 6.5); the environment-dependent breathing rate, $B R_{n}$ (Section 6.3); the amount of time population groups spend in defined environments, $t_{n, m}$ (Section 6.3); the fraction of total population in specified population groups, $P P_{m}$ (Section 6.3), the fraction of houses with evaporative coolers, $f_{\text {cooler }}$ (Section 6.3); and the annual evaporative cooler use factor, $f_{\text {use }}$ (Section 6.3). 


\subsubsection{Inhalation of Carbon-14}

The inhalation dose from ${ }^{14} \mathrm{C}$ is calculated using a method similar to that used for assessment of inhalation dose from resuspended particulates (BSC 2004 [DIRS 169460], Section 6.4.8.3), which is

$$
\begin{aligned}
D_{i n h, g, C-14} & =\sum_{n} D_{i n h, g, C-14, n} \\
& =D C F_{i n h, C-14} C a_{g, C-14} \sum_{n} B R_{n}\left(\sum_{m} P P_{m} t_{n, m}\right)
\end{aligned}
$$

where

$$
\begin{array}{ll}
D_{\text {inh, }, \text { C-14 }} & =\text { annual dose from inhalation of }{ }^{14} \mathrm{C} \text { in gaseous form }(\mathrm{Sv} / \mathrm{yr}) \\
D_{\text {inh, } g, C-14, n} & =\text { annual dose from inhalation of gaseous }{ }^{14} \mathrm{C} \text { for environment } n(\mathrm{~Sv} / \mathrm{yr}) \\
C a_{g, C-14} & \text { activity concentration of }{ }^{14} \mathrm{C} \text { in air (indoors and outdoors) }\left(\mathrm{Bq} / \mathrm{m}^{3}\right) \\
D C F_{\text {inh, } C-14} & =\text { DCF for inhalation of }{ }^{14} \mathrm{C}(\mathrm{Sv} / \mathrm{Bq}) .
\end{array}
$$

This analysis develops values for the inhalation DCF for ${ }^{14} \mathrm{C}, D C F_{\text {inh, }}$ - 14 (Section 6.5); the environment-dependent breathing rate, $B R_{n}$ (Section 6.3); the amount of time population groups spend in defined environments, $t_{n, m}$ (Section 6.3); and the fraction of total population in specified population groups, $P P_{m}$ (Section 6.3).

\subsubsection{Inhalation of Radon Decay Products}

The dose due to inhalation of radon decay products is evaluated in the biosphere model (BSC 2004 [DIRS 169460], Section 6.4.8.4) as

$$
\begin{aligned}
D_{\text {inh }, g, R n-222}= & \sum_{n} D_{i n h, g, R n-222, n} \\
= & \sum_{n=1}^{5} C a_{g, R n-222, n} F_{n} D C F_{i n h, R n-222, n} B R_{n}\left(\sum_{m} P P_{m} t_{n, m}\right)+ \\
& \sum_{n=3}^{4} C a_{g, R n-222, e} f_{\text {cooler }} f_{\text {use }} D C F_{\text {inh }, R n-222, n} B R_{n}\left(\sum_{m} P P_{m} t_{n, m}\right)
\end{aligned}
$$

where

$$
\begin{aligned}
& D_{\text {inh, }, \text {, Rn-222 }} \quad=\text { annual dose from inhalation of }{ }^{222} \mathrm{Rn} \text { decay products (Sv/yr) } \\
& D_{i n h, g, R n-222, n}=\text { annual dose from inhalation of }{ }^{222} \mathrm{Rn} \text { decay products for } \\
& \text { environment } n \text { (Sv/yr) } \\
& C a_{g, R n-222, n} \quad=\text { activity concentration of }{ }^{222} \mathrm{Rn} \text { in air for environment } n\left(\mathrm{~Bq} / \mathrm{m}^{3}\right) \\
& F_{n} \quad=\text { correction factor to account for the use of evaporative coolers in } \\
& \text { indoor environment } n \text { (dimensionless), } 1 \text { for } n=1 \& 2 \text {, and } \\
& \left(1-f_{\text {cooler }} \times f_{\text {use }}\right) \text { for } n=3 \& 4 \\
& D C F_{i n h, R n-22, n}=\text { DCF for inhalation of }{ }^{222} \mathrm{Rn} \text { decay products for environment } n \\
& (\mathrm{~Sv} / \mathrm{Bq})
\end{aligned}
$$




$$
\begin{aligned}
C a_{g, R n-222, e}= & \text { activity concentration of }{ }^{222} \mathrm{Rn} \text { in indoor air at a high ventilation rate } \\
& \text { during evaporative cooler in operation }\left(\mathrm{Bq} / \mathrm{m}^{3}\right) .
\end{aligned}
$$

This analysis develops values for the environment-dependent DCFs for inhalation of ${ }^{222} \mathrm{Rn}$ decay products, $D C F_{i n h}, R n-222, n$ (Section 6.5); the environment-dependent breathing rate, $B R_{n}$ (Section 6.3); the amount of time population groups spend in defined environments, $t_{n, m}$ (Section 6.3); and the fraction of total population in specified population groups, $P P_{m}$ (Section 6.3).

\subsubsection{Evaluation of Ingestion Exposure}

The total ingestion dose includes contributions from ingestion of water, crops, animal products, fish, and soil (BSC 2004 [DIRS 169460], Section 6.4.9) and is expressed as

$$
D_{i n g, i}=D_{i n g, w, i}+D_{i n g, p, i}+D_{i n g, d, i}+D_{i n g, f, i}+D_{i n g, s, i}
$$

where

$$
\begin{aligned}
D_{\text {ing, } i}= & \text { annual dose from ingestion of radionuclide } i(\mathrm{~Sv} / \mathrm{yr}) \\
D_{\text {ing, }, i}= & \text { annual dose from ingestion of radionuclide } i \text { in drinking water (Sv/yr) } \\
D_{\text {ing, }, i}= & \text { annual dose from ingestion of radionuclide } i \text { in crops (Sv/yr) } \\
D_{\text {ing, }, i}= & \text { annual dose from ingestion of radionuclide } i \text { in animal products (Sv/yr) } \\
D_{\text {ing, }, i, i=} & \text { annual dose from ingestion of radionuclide } i \text { in fish (Sv/yr) } \\
D_{\text {ing, }, i=}= & \text { annual dose from inadvertent ingestion of radionuclide } i \text { in surface soil } \\
& (\mathrm{Sv} / \mathrm{yr})
\end{aligned}
$$

Equation 6.2-7 can be further expressed (BSC 2004 [DIRS 169460]; Sections 6.4.9.1 through 6.4.9.5) as

$$
\begin{aligned}
D_{\text {ing, },}= & E D C F_{\text {ing,i }} C w_{i} U w+\sum_{l}\left[E D C F_{i n g, l} \sum_{j}\left(C p_{l, j} U p_{j}\right)\right]+\sum_{l}\left[E D C F_{i n g, l} \sum_{k}\left(C d_{l, k} U d_{k}\right)\right] \\
& +E D C F_{i n g, i} C f_{i} U f+\sum_{l}\left(E D C F_{i n g, l} C s_{m, l} U s\right)
\end{aligned}
$$

where

$$
\begin{aligned}
& E D C F_{\text {ing, } i}=\text { effective DCF for ingestion of radionuclide } i(\mathrm{~Sv} / \mathrm{Bq}) \\
& C w_{i} \quad=\text { activity concentration of radionuclide } \mathrm{i} \text { in groundwater }(\mathrm{Bq} / \mathrm{L}) \\
& \text { Uw } \quad=\text { annual consumption rate of drinking water for the receptor }(\mathrm{L} / \mathrm{yr}) \\
& l=\text { index of radionuclide decay chain member, } l=0 \text { for primary radionuclide } \\
& E D C F_{\text {ing, } l}=\text { effective DCF for ingestion of radionuclide } l \text { in decay chain of primary } \\
& \text { radionuclide } i(\mathrm{~Sv} / \mathrm{Bq}) \\
& C p_{l, j} \quad=\text { activity concentration of a primary radionuclide } l \text { in crop type } j(\mathrm{~Bq} / \mathrm{kg}) \\
& j \quad=\text { index of crop type, } j=1 \text { for leafy vegetables, } 2 \text { for other vegetables, } 3 \text { for } \\
& \text { fruit, and } 4 \text { for grain } \\
& U p_{j} \quad=\text { annual consumption rate of crop type } j(\mathrm{~kg} / \mathrm{yr}) \\
& C d_{l, k} \quad=\text { activity concentration of primary radionuclide } l \text { in animal product type } k
\end{aligned}
$$




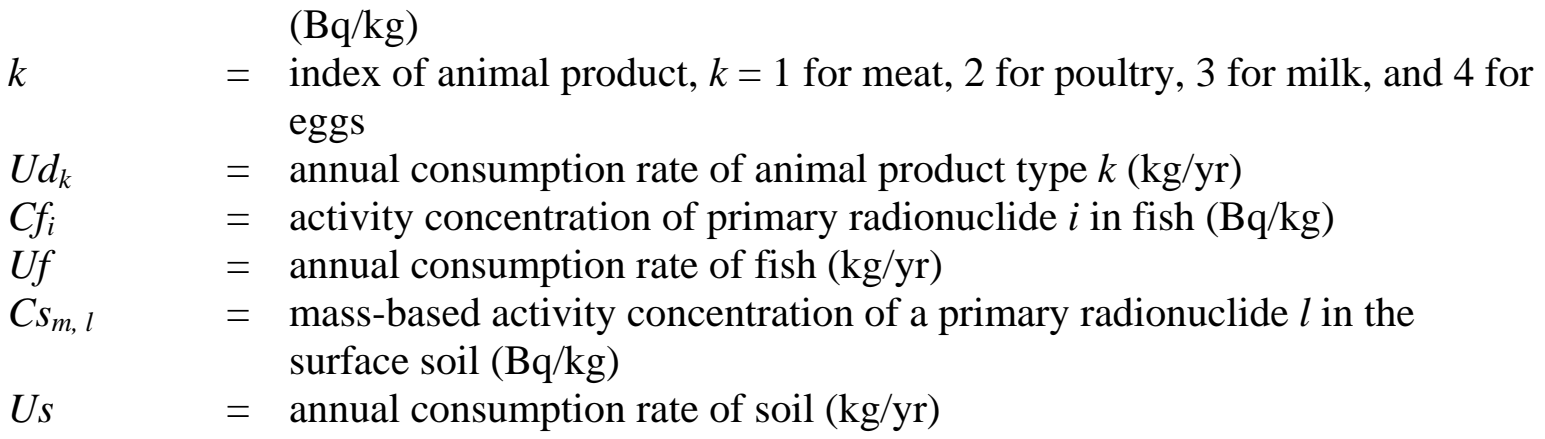

This analysis develops values for the ingestion DCFs for individual radionuclides which are used to develop the effective DCFs for ingestion, $E D C F_{\text {ing,l }}$ (Section 6.5); the annual consumption rates of crops by crop type, $U p_{j}$ (Section 6.4); the annual consumption rates of animal products by animal product type, $U d_{k}$ (Section 6.4); annual consumption rates of fish, Uf (Section 6.4); and the annual consumption rate of soil, Us (Section 6.4).

\subsection{LIFESTYLE CHARACTERISTICS OF THE RECEPTOR}

In this section, distributions for parameters in the biosphere model related to the lifestyle and physiological characteristics of the RMEI are developed. These parameters include population proportions, annual exposure time, breathing rates, the fraction of houses with evaporative coolers, and the evaporative cooler use factor.

\subsubsection{Proportion of Population}

Estimates of the proportion of the adult population in the Amargosa Valley classified into the four population groups (described in Section 6.2; $P P_{m}$, with $m=$ population category) are used to estimate radiation exposure from inhalation and external exposure pathways.

Estimates of the proportion of the adult population in the Amargosa Valley within each of the four categories were developed from 2000 census data (Bureau of the Census 2002 [DIRS 159728]) on employment (Tables 6-2 and 6-4) and commuting time (Table 6-3) of people in the Amargosa Valley census county division. The standard error of the estimated proportions, $S E(p)$, were calculated using methods recommended by the Bureau of the Census for calculating standard error of percentages (Bureau of the Census 2002 [DIRS 160179], pp. 8-6 and 8-21) as

$$
S E(p)=D F \sqrt{\left(\frac{5}{N} p(1-p)\right)}
$$

where

$$
\begin{array}{ll}
N & =\text { total population or population-group size } \\
p & =\text { estimated proportion of the population in a group } \\
D F & =\text { design factor. }
\end{array}
$$

The design factor is a state and characteristic-specific correction factor determined from the percent of the population sampled. In the Amargosa Valley census county division, 11.1 percent 
of the population was sampled (Bureau of the Census 2002 [DIRS 159728], Table P4). The associated design factors for Nevada are 1.3 for usual hours worked per week and weeks worked in 1999 and 1.4 for travel time to work and industry of employment (Bureau of the Census 2002 [DIRS 160179], Table C for Nevada).

With two exceptions, uniform distributions with a minimum one standard error lower than the estimated proportion and a maximum one standard error higher than the estimate are to be used in the biosphere model to define the proportion of non-workers, commuters, and local outdoor workers (Table 6-5). To account for uncertainty in the distribution of ash following a volcanic eruption, the lower bound of the distribution of commuters and the upper bound of the distribution of local outdoor workers are calculated as the estimated proportion plus or minus two standard errors. The proportion of local indoor workers is calculated in the model as one minus the sum of the three other proportions; the estimated proportion and standard error for that group are presented below only for comparison.

Non-Workers-Non-workers are adults who are unemployed or not in the labor force, including retired persons. The number of non-workers was estimated based on information from the 2000 census on the work status during 1999 of Amargosa Valley residents 16 years or older. Of an estimated total of 862 residents 16 years of age or older, 338 (39.2 percent) were not in the work force in 1999 (Table 6-2). The standard error of this estimate is 4.8 percent (calculated as $\left.1.3 \times[(5 / 862) \times 0.392 \times 0.608]^{1 / 2}\right)$. The uniform distribution to be used in the biosphere model for this population group has minimum and maximum values of 34.4 percent and 44.0 percent, respectively (estimate proportion \pm one standard error). This distribution is to be used for the groundwater and volcanic ash exposure scenarios.

The estimated number of Amargosa Valley residents that worked differs between Table 6-2 (524 working residents) and Tables 6-3 and 6-4 (449 working residents). Table 6-2 summarizes employment status for all of 1999; the estimate of the total number of working residents includes people who worked part time. Tables 6-3 and 6-4 report information on commute time and industry of employment the week before survey forms were filled out (in April 2000), and therefore do not include information about people temporarily unemployed at that time. Because Table 6-2 includes information on part-time workers, and because information from that table is used in Section 6.3.2 to estimate the average number of hours worked, it is the more applicable source of information on the proportion of working (524 of $862=60.8$ percent) and non-working (338 of $862=39.2$ percent) residents. Estimates of the proportion of commuters and local outdoor workers are derived from information in Tables 6-3 and 6-4; therefore, these values must be multiplied by the percentage of the working population in 1999 (60.8 percent). To propagate errors from both estimates, the standard error, $S E\left(p_{1} p_{2}\right)$, was calculated (using an equation modified from Knoll 1989 [DIRS 161052], p. 90; Bureau of the Census 2002 [DIRS 160179], p. 8-7) as

$$
S E\left(p_{1} p_{2}\right)=p_{1} p_{2} \sqrt{\frac{S E\left(p_{1}\right)^{2}}{p_{1}{ }^{2}}+\frac{S E\left(p_{2}\right)^{2}}{p_{2}{ }^{2}}}
$$


where

$$
\begin{aligned}
& p_{1}=\quad \begin{array}{l}
\text { estimated proportion of the population in group } 1 \text { (the proportion of workers in } \\
\text { the population) }
\end{array} \\
& p_{2}=\begin{array}{l}
\text { estimated proportion of the population in group } 2 \text { (the proportion of commuters } \\
\text { or local outdoor workers) }
\end{array}
\end{aligned}
$$

\begin{tabular}{|c|c|c|c|}
\hline Working Time & $\begin{array}{c}\text { Number of } \\
\text { Males }\end{array}$ & $\begin{array}{c}\text { Number of } \\
\text { Females }\end{array}$ & Total \\
\hline Worked in 1999 & 296 & 228 & 524 \\
\hline \multicolumn{4}{|l|}{ Usually worked $\geq 35$ hours/week } \\
\hline 50-52 weeks & 204 & 93 & 297 \\
\hline 48-49 weeks & 8 & 21 & 29 \\
\hline 40-47 weeks & & 6 & 6 \\
\hline 27-39 weeks & 11 & 3 & 14 \\
\hline 14-26 weeks & 19 & 15 & 34 \\
\hline $1-13$ weeks & 29 & & 29 \\
\hline \multicolumn{4}{|c|}{ Usually worked 15-34 hours/week } \\
\hline 50-52 weeks & & 30 & 30 \\
\hline 48-49 weeks & 8 & 8 & 16 \\
\hline 40-47 weeks & & 11 & 11 \\
\hline 27-39 weeks & & 12 & 12 \\
\hline 14-26 weeks & & 14 & 14 \\
\hline $1-13$ weeks & 10 & 15 & 25 \\
\hline \multicolumn{4}{|l|}{ Usually worked 1-14 hours/week } \\
\hline 50-52 weeks & 7 & & 7 \\
\hline \multicolumn{4}{|l|}{ 48-49 weeks } \\
\hline \multicolumn{4}{|l|}{ 40-47 weeks } \\
\hline \multicolumn{4}{|l|}{ 27-39 weeks } \\
\hline \multicolumn{4}{|l|}{ 14-26 weeks } \\
\hline \multicolumn{4}{|l|}{$1-13$ weeks } \\
\hline Did not Work in 1999 & 165 & 173 & 338 \\
\hline Total & 461 & 401 & 862 \\
\hline
\end{tabular}

Table 6-2. Work Status of Amargosa Valley Residents in 1999

Source: Bureau of the Census 2002 (DIRS 159728), Table P47.

Commuters-This group includes employed people who would work in uncontaminated areas. For the groundwater exposure scenario, it is assumed that this group includes all employed adults in the Amargosa Valley who commute 10 minutes or more one way to work (Section 5.1). An estimated 64.4 percent (289 of 449) of Amargosa Valley residents 16 years or older that worked the week prior to census commuted 10 minutes or more (Table 6-3). The standard error of this estimate is 7.1 percent (calculated as $1.4 \times[(5 / 449) \times 0.644 \times 0.356]^{1 / 2}$ ). This estimate must be multiplied by the proportion of the entire population 16 years or older that was employed in 1999 (60.8 percent); thus, the estimate of adults in the Amargosa Valley that commute 10 minutes or more is 39.2 percent (i.e., $0.608 \times 0.644$ ), with a standard error of 5.3 percent 
(calculated as $(0.608 \times 0.644) \times\left[\left(0.048^{2} / 0.608^{2}\right)+\left(0.071^{2} / 0.644^{2}\right)\right]^{1 / 2}$ using Equation 6.3-2) The distribution of commuters for the groundwater exposure scenario is uniform with minimum and maximum values of 33.9 percent and 44.5 percent, respectively (estimated proportion \pm one standard error).

Table 6-3. Travel Time to Work for Amargosa Valley Residents

\begin{tabular}{|c|c|}
\hline Travel Time (Minutes) $^{a}$ & Number of Residents \\
\hline 0 (Worked at home) & 6 \\
\hline Less than 5 & 84 \\
\hline 5 to 9 & 70 \\
\hline 10 to 14 & 98 \\
\hline 15 to 19 & 35 \\
\hline 20 to 24 & 64 \\
\hline 25 to 29 & 0 \\
\hline 30 to 34 & 0 \\
\hline 35 to 39 & 14 \\
\hline 40 to 44 & 23 \\
\hline 45 to 49 & 24 \\
\hline 60 to 89 & 9 \\
\hline 90 or more & 22 \\
\hline Total & 449 \\
\hline
\end{tabular}

Source: Bureau of the Census 2002 (DIRS 159728), Table P31.

a One-way commute time for employed residents 16 years or older during the week prior to the April 2000 census.

For the volcanic ash exposure scenario, it is assumed that people who commute 35 minutes or more one way are not exposed to contaminated ash while at work (Section 5.1). An estimated 20.5 percent (92 of 449) of Amargosa Valley residents 16 years or older that worked the week prior to the census commuted 35 minutes or more (Table 6-3). The standard error of this estimate is 6.0 percent $\left(1.4 \times[(5 / 449) \times 0.205 \times 0.795]^{1 / 2}\right)$. The estimate of the total population of adults who commute 35 minutes or longer is 12.5 percent (i.e., $0.608 \times 0.205$ ), with a standard error of 3.8 percent $\left.(0.608 \times 0.205) \times\left[\left(0.048^{2} / 0.608^{2}\right)+\left(0.060^{2} / 0.205^{2}\right)\right]^{1 / 2}\right)$. Because of uncertainty about where ash from a volcanic eruption at Yucca Mountain would fall (Section 5.1), the minimum value of the distribution of commuters is calculated as the estimated proportion minus two standard errors. Therefore, the distribution of commuters for the volcanic ash exposure scenario is uniform with minimum and maximum values of 4.9 percent and 16.3 percent, respectively.

Local Outdoor Workers-This group includes people who work outdoors and disturb (and therefore resuspend) contaminated soil. It is assumed that local outdoor workers include all agricultural works, 25 percent of construction workers, 10 percent of utility workers, and 10 percent of workers in the mining industry (Section 5.2). The estimated number of local outdoor workers in 2000 was 41 (26 agricultural workers, 2 of 7 construction workers, 1 of 8 utility workers, and 12 of 119 miners [Table 6-4]). This is 9.1 percent of the 449 Amargosa Valley residents 16 years or older that worked the week prior to the census, with a standard error of 4.2 percent $\left(1.4 \times((5 / 449) \times 0.091 \times 0.909)^{1 / 2}\right)$. The estimate of the total population of 
local outdoor workers is 5.5 percent (i.e., $0.608 \times 0.091$ ), with a standard error of 2.6 percent $\left((0.608 \times 0.091) \times\left[\left(0.048^{2} / 0.608^{2}\right)+\left(0.042^{2} / 0.091^{2}\right)\right]^{1 / 2}\right)$.

Table 6-4. Industry of Employed Amargosa Valley Residents in 2000

\begin{tabular}{|c|c|c|c|}
\hline Industry of Employment ${ }^{a}$ & $\begin{array}{c}\text { Number of } \\
\text { Males }\end{array}$ & $\begin{array}{l}\text { Number of } \\
\text { Females }\end{array}$ & Total \\
\hline Agriculture & 26 & & 26 \\
\hline Mining & 101 & 18 & 119 \\
\hline Construction & 7 & & 7 \\
\hline Retail trade & 19 & 14 & 33 \\
\hline Transportation and warehousing & 23 & 26 & 49 \\
\hline Utilities & 8 & & 8 \\
\hline Educational services & & 47 & 47 \\
\hline Health care and social assistance & 20 & 8 & 28 \\
\hline Arts, entertainment, recreation, accommodation, and food services & 22 & 71 & 93 \\
\hline Other services (except public administration) & 6 & 15 & 21 \\
\hline Public administration & & 18 & 18 \\
\hline Total & 232 & 217 & 449 \\
\hline
\end{tabular}

Source: Bureau of the Census 2002 (DIRS 159728), Table P49.

a Industry of employed residents 16 years or older during the week prior to the April 2000 census.

The distribution of local outdoor workers for the groundwater exposure scenario is uniform with a minimum of 2.9 percent and a maximum of 8.1 percent (estimated proportion \pm one standard error). Because of uncertainty about where ash from a volcanic eruption at Yucca Mountain would fall (Section 5.2), the maximum value of the distribution of this population group for the volcanic ash exposure scenario is calculated as the estimate plus two standard errors. Thus, the distribution of local outdoor workers for that exposure scenario is uniform with minimum and maximum values of 2.9 percent and 10.7 percent, respectively.

Local Indoor Workers-This group includes all people who work indoors (or outdoors in enclosed vehicles) in areas contaminated by groundwater or ash. In the biosphere model, the proportion of local indoor workers is calculated as one minus the sum of the other three population proportions. For the groundwater exposure scenario, the estimated proportion of local indoor workers is 16.1 percent (100 percent minus 39.2 percent non-workers, 39.2 percent commuters, and 5.5 percent local outdoor workers). For the volcanic ash exposure scenario, the estimated proportion in this group is 42.8 percent (100 percent minus 39.2 percent non-workers, 12.5 percent commuters, and 5.5 percent local outdoor workers).

The population proportion values are summarized in Table 6-5.

\subsubsection{Exposure Times}

To calculate exposure times for the five environments (Section 6.2), time spent conducting six activities (working, commuting, outdoors not working, active outdoors, sleeping, and away from the Amargosa Valley) is estimated in Section 6.3.2.1. The time estimates are then used to develop exposure times for each of the four population groups (Section 6.3.2.2). 
Table 6-5. Population Proportions

\begin{tabular}{|c|c|c|c|c|}
\hline \multirow[b]{2}{*}{ Group } & \multirow{2}{*}{$\begin{array}{c}\text { Estimated } \\
\text { Percentage }\end{array}$} & \multirow[b]{2}{*}{ Standard Error ${ }^{a}$} & \multicolumn{2}{|c|}{ Uniform Distribution $^{\text {b }}$} \\
\hline & & & Minimum & Maximum \\
\hline \multicolumn{5}{|c|}{ Groundwater Release Exposure Scenario } \\
\hline Non-Workers & $39.2 \%$ & $4.8 \%$ & $34.4 \%$ & $44.0 \%$ \\
\hline Commuters & $39.2 \%$ & $5.3 \%$ & $33.9 \%$ & $44.5 \%$ \\
\hline Local Outdoor Workers & $5.5 \%$ & $2.6 \%$ & $2.9 \%$ & $8.1 \%$ \\
\hline Local Indoor Workers & $16.1 \%{ }^{\mathrm{c}}$ & & & \\
\hline \multicolumn{5}{|c|}{ Volcanic Release Exposure Scenario } \\
\hline Non-Workers & $39.2 \%$ & $4.8 \%$ & $34.4 \%$ & $44.0 \%$ \\
\hline Commuters & $12.5 \%$ & $3.8 \%$ & $4.9 \%$ & $16.3 \%$ \\
\hline Local Outdoor Workers & $5.5 \%$ & $2.6 \%$ & $2.9 \%$ & $10.7 \%$ \\
\hline Local Indoor Workers & $42.8 \%^{c}$ & & & \\
\hline
\end{tabular}

a Calculated using equations 6.3-1 and 6.3-2.

b Calculated as estimated percentage $\pm 1 \mathrm{SE}$, except volcanic-commuters (minimum = estimated percentage $2 \mathrm{SE}$ ) and volcanic-local outdoor workers (maximum = estimated percentage $+2 \mathrm{SE}$ ).

${ }^{c}$ Calculated in the biosphere model as 100 percent minus the sum of the other three percentages.

\subsubsection{Behavior Times}

Time Spent Working-The average amount of time people spent working (of those who worked), and the associated standard error, was calculated from census data on hours worked per week and weeks worked per year by Amargosa Valley residents 16 years or older in 1999 (Table 6-6). The average of this categorical data set was calculated (using equations recommended by the Bureau of the Census 2002 [DIRS 160179], pp. 8-8 and 8-9) as

$$
\bar{x}=\sum_{j}^{c} p_{j} m_{j}
$$

where

$$
\begin{array}{ll}
c & =\text { number of categories into which the data is divided } \\
p_{j} & =\text { portion of the total number of workers in category } j \\
m_{j} & =\text { midpoint of each category } j
\end{array}
$$

The Bureau of the Census (2002 [DIRS 159728], Table P47) presents time worked as a combination of hours worked per week and weeks worked per year. These distributions were combined to estimate the number of hours worked in 1999. The estimated mean of the combined distributions was used as $m_{j}$ in Equation 6.3-3, rather than the midpoint of each category. The mean was calculated as the product of the midpoints of hours per week and hours per year (Table 6-6) for each category, based on an equal probability of occurrence (i.e., uniform distribution) of each value within a category. This was done because the midpoint overestimates the average number of hours worked per year unless there is a correlation between number of hours worked per week and weeks worked per year. 
Table 6-6. Estimated Number of Hours Worked Per Year

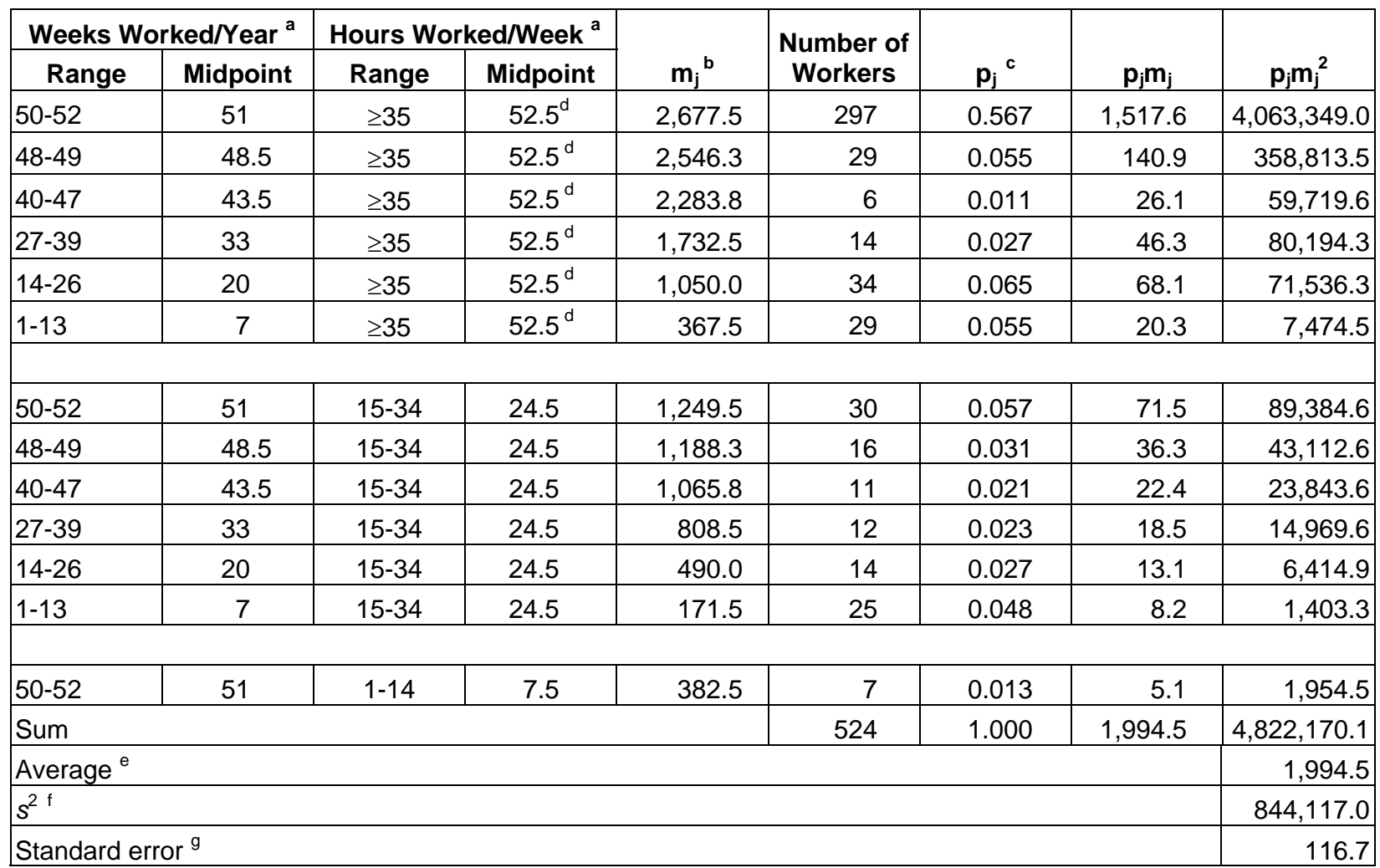

Source: Bureau of the Census 2002 (DIRS 159728), Table P47).

${ }^{a}$ Estimated number of hours worked in 1999 by employed residents of the Amargosa Valley.

${ }^{\mathrm{b}} m_{j}=$ (midpoint of weeks worked per year) $\times$ (midpoint of hours worked per week).

${ }^{c} p_{j}=$ portion of total workers (524) in category $j$.

d Calculated as (3/2) $\times$ (lower limit of interval), as recommended by Bureau of the Census (2002 [DIRS 160179], p. 89).

e Calculated using equation 6.3-3.

${ }^{f}$ Calculated using equation 6.3-5.

${ }^{9}$ Calculated using equation 6.3-4, with DF $=1.3$

The standard error [SE $(\bar{x})]$ was calculated (Bureau of the Census 2002 [DIRS 160179], p. 8-8) as

$$
S E(\bar{x})=\sqrt{\frac{5}{N} \times s^{2}} \times D F
$$

with $D F=1.3$ (Bureau of the Census 2002 [DIRS 160179], Table C for Nevada) and $s^{2}$ calculated as

$$
s^{2}=\sum_{j=1}^{c} p_{j} m_{j}{ }^{2}-(\bar{x})^{2}
$$

The average number of hours worked in 1999 by employed residents of Amargosa Valley 16 years or older was 1,994.5 hours per year, with a standard error of 116.7 hours (Table 6-6). 
This is an annual average of 5.5 hours per day (1,994.5 hours per year $\div 365$ days per year), with a standard error of 0.3 hours. Converted to hours worked per week $(1,994.5 \div 52$ weeks $=38.4$ hours per week), this is similar to the national average number of hours worked by persons in all industries (39.7 hours; Bureau of the Census 2001 [DIRS 160177], Table 582).

Time Spent Commuting-The average amount of time people that work spend commuting was calculated based on assumptions about how long it would take to drive out of the contaminated area (Section 5.1) and from census data on commuting time of 16-year and older residents of the Amargosa Valley the week prior to the 2000 census (Tables 6-7 and 6-8). Averages and standard error are calculated using equations 6.3-3, 6.3-4, and 6.3-5, with a DF $=1.4$ (Bureau of the Census 2002 [DIRS 160179], Table C for Nevada).

Table 6-7. Commute Time (minutes/day) for the Groundwater Exposure Scenario

\begin{tabular}{|c|c|c|c|c|c|c|c|c|c|c|}
\hline \multirow{2}{*}{$\begin{array}{l}\text { Travel } \\
\text { Time }^{a}\end{array}$} & \multirow[b]{2}{*}{$N^{b}$} & \multicolumn{4}{|c|}{ Non-Commuters } & \multicolumn{5}{|c|}{ Commuters } \\
\hline & & $m_{j}{ }^{c}$ & $p_{j}{ }^{d}$ & $p_{j} m_{j}$ & $\mathrm{p}_{\mathrm{j}} \mathrm{m}_{\mathrm{j}}{ }^{2}$ & $N^{b}$ & $m_{j}{ }^{e}$ & $p_{j}^{d}$ & $p_{j} m_{j}$ & $\mathrm{p}_{\mathrm{j}} \mathrm{m}_{\mathrm{j}}{ }^{2}$ \\
\hline 0 & 6 & 0 & 0.04 & 0.00 & 0.00 & & & & & \\
\hline$<5$ & 84 & 5 & 0.53 & 2.63 & 13.13 & & & & & \\
\hline $5-9$ & 70 & 14 & 0.44 & 6.13 & 85.75 & & & & & \\
\hline $10-14$ & & & & & & 98 & 4 & 0.34 & 1.36 & 5.43 \\
\hline $15-19$ & & & & & & 35 & 14 & 0.12 & 1.70 & 23.74 \\
\hline $20-24$ & & & & & & 64 & 24 & 0.22 & 5.31 & 127.56 \\
\hline $25-29$ & & & & & & 0 & 34 & 0.00 & 0.00 & 0.00 \\
\hline $30-34$ & & & & & & 0 & 44 & 0.00 & 0.00 & 0.00 \\
\hline $35-39$ & & & & & & 14 & 54 & 0.05 & 2.62 & 141.26 \\
\hline $40-44$ & & & & & & 23 & 64 & 0.08 & 5.09 & 325.98 \\
\hline $45-59$ & & & & & & 24 & 84 & 0.08 & 6.98 & 585.97 \\
\hline $60-89$ & & & & & & 9 & 129 & 0.03 & 4.02 & 518.23 \\
\hline$>90^{f}$ & & & & & & 22 & 250 & 0.08 & 19.03 & $4,757.79$ \\
\hline Sum & 160 & & 1.00 & 8.75 & 98.88 & 289 & & 1.00 & 46.10 & $6,485.94$ \\
\hline Average $^{g}$ & & & & & 8.75 & & & & & 46.10 \\
\hline$s^{2 h}$ & & & & & 22.31 & & & & & $4,360.70$ \\
\hline \multicolumn{2}{|c|}{ Standard Error ' } & & & & 1.17 & & & & & 12.16 \\
\hline
\end{tabular}

Source: Bureau of the Census 2002 (DIRS 159728), Table P31.

a One-way travel time to work in minutes.

${ }^{\mathrm{b}} \mathrm{N}=$ number of workers $\geq 16$ years old within each travel-time category the week before the 2000 census.

${ }^{c} \mathrm{~m}_{\mathrm{j}}=$ midpoint of total daily travel time in areas contaminated by groundwater, calculated as twice the midpoint of the one-way travel time interval.

${ }^{d} p_{j}=$ proportion of total workers in each category (160 non-commuters and 289 commuters).

e $\mathrm{m}_{\mathrm{j}}=$ midpoint of total daily travel time in areas not contaminated by groundwater, calculated as twice the midpoint of the one-way travel time interval minus 20 minutes travel time in contaminated areas.

$\mathrm{f}$ midpoint of one-way travel time calculated as $(3 / 2) \times$ (lower limit of interval), as recommended by Bureau of the Census (2002 [DIRS 160179], p. 8-9)

${ }^{g}$ Calculated using equation 6.3-3.

h Calculated using equation 6.3-5.

I Calculated using equation 6.3-4, with DF $=1.4$. 
Table 6-8. Commute Time (minutes/day) for the Volcanic Ash Exposure Scenario

\begin{tabular}{|c|c|c|c|c|c|c|c|c|c|c|}
\hline \multirow{2}{*}{$\begin{array}{l}\text { Travel } \\
\text { Time }^{\text {a }} \\
\end{array}$} & \multicolumn{5}{|c|}{ Non-Commuters } & \multicolumn{5}{|c|}{ Commuters } \\
\hline & $N^{b}$ & $m_{j}{ }^{c}$ & $p_{j}^{d}$ & $p_{j} m_{j}$ & $\mathrm{p}_{j} \mathrm{~m}_{\mathrm{j}}{ }^{2}$ & $N^{b}$ & $m_{j}{ }^{e}$ & $p_{j}^{d}$ & $p_{j} m_{j}$ & $\mathrm{p}_{j} \mathrm{~m}_{\mathrm{j}}^{2}$ \\
\hline 0 & 6 & 0 & 0.02 & 0.00 & 0.00 & & & & & \\
\hline$<5$ & 84 & 5 & 0.24 & 1.18 & 5.88 & & & & & \\
\hline $5-9$ & 70 & 14 & 0.20 & 2.75 & 38.43 & & & & & \\
\hline $10-14$ & 98 & 24 & 0.27 & 6.59 & 158.12 & & & & & \\
\hline $15-19$ & 35 & 34 & 0.10 & 3.33 & 113.33 & & & & & \\
\hline $20-24$ & 64 & 44 & 0.18 & 7.89 & 347.07 & & & & & \\
\hline $25-29$ & 0 & 54 & 0.00 & 0.00 & 0.00 & & & & & \\
\hline $30-34$ & 0 & 64 & 0.00 & 0.00 & 0.00 & & & & & \\
\hline $35-39$ & & & & & & 14 & 4 & 0.15 & 0.61 & 2.43 \\
\hline $40-44$ & & & & & & 23 & 14 & 0.25 & 3.50 & 49.00 \\
\hline $45-59$ & & & & & & 24 & 34 & 0.26 & 8.87 & 301.57 \\
\hline $60-89$ & & & & & & 9 & 79 & 0.10 & 7.73 & 610.53 \\
\hline$>90^{f}$ & & & & & & 22 & 200 & 0.24 & 47.83 & $9,565.22$ \\
\hline Sum & 357 & & 1.00 & 21.73 & 662.83 & 92 & & 1.00 & 68.53 & $10,528.75$ \\
\hline Average $^{\mathrm{g}}$ & & & & & 21.73 & & & & & 68.53 \\
\hline$s^{2 h}$ & & & & & 190.59 & & & & & $5,832.03$ \\
\hline Standard E & or $^{1}$ & & & & 2.29 & & & & & 24.92 \\
\hline
\end{tabular}

Source: Bureau of the Census 2002 (DIRS 159728), Table P31.

a One-way travel time to work in minutes.

${ }^{\mathrm{b}} \mathrm{N}=$ number of workers $\geq 16$ years old within each travel-time category the week before the 2000 census.

${ }^{c} m_{j}=$ midpoint of total daily travel time in areas contaminated by volcanic ash.

${ }^{\mathrm{d}} p_{j}=$ proportion of total workers in each category (357 non-commuters and 92 commuters).

e $\mathrm{m}_{\mathrm{j}}=$ midpoint of total daily travel time in areas not contaminated by volcanic ash, calculated as twice the midpoint of the one-way travel time interval minus 70 minutes travel time in contaminated areas.

$\mathrm{f}$ midpoint of one-way travel time calculated as $(3 / 2) \times$ (lower limit of interval), as recommended by Bureau of the Census (2002 [DIRS 160179], p. 8-9)

${ }^{g}$ Calculated using equation 6.3-3.

h Calculated using equation 6.3-5.

I Calculated using equation 6.3-4, with DF = 1.4.

For the groundwater scenario, it is assumed that persons who commute 10 minutes or more one-way to work are employed outside of the area contaminated by groundwater (Section 5.1). The average round-trip commute time outside of contaminated areas for 289 Amargosa Valley residents 16 years or older that commuted 10 minutes or more the week prior to the 2000 census was 46 minutes, with a standard error of 12 minutes (Table 6-7). Based on an average workday of 8 hours (selected because 409 of 524 persons worked 35 hours or longer per week, Table 6-6), the average number of days worked per year is 249 (average of 1,995 hours worked per year [Table 6-6] divided by 8 hours per day). The total annual commute time outside of the contaminated area is 11,454 minutes per year (i.e., 46 minutes $\times 249$ days), or 31 minutes per day. The annualized standard error of this estimate is 8 minutes (i.e., [12 minutes per day worked] $\times$ [249 days worked per year $] \div$ [365 days per year]). For use in the model, this estimate is rounded to $0.5 \pm 0.1$ hours per day.

For commuters, the round-trip commute time inside the area contaminated by groundwater is 20 minutes. This equals an annual average of 14 minutes per day, or 0.2 hours per day 
([20 minutes per day worked] $\times$ [249 days worked per year] $\div$ [365 days per year]). Because all commuters must travel at least that amount of time, no measure of variance is associated with this estimate.

For non-commuters (i.e., those who commute less than 10 minutes one way), the average round-trip commute within the area contaminated by groundwater is 9 minutes, with an annualized standard error of about 1 minute (Table 6-7). This equals an annual average of 6 minutes per day, or 0.1 hours per day ([9 minutes per day worked] $\times$ [249 days worked per year $] \div$ [365 days per year]). Because the standard error of this measure is small, no measure of variance is associated with this estimate.

For the volcanic ash exposure scenario, it is assumed that all persons who commute 35 minutes or longer one-way work outside of the area contaminated by ash (Section 5.1). The average round-trip commute time outside of the contaminated area for 92 Amargosa Valley residents 16 years or older that commuted 35 minutes or longer the week prior to the 2000 census was 69 minutes, with a standard error of 25 minutes (Table 6-8). Based on an average workday of 8 hours, the total annual commute time outside of the contaminated area is 17,181 minutes per year (i.e., 69 minutes $\times 249$ days), or 47 minutes per day. The standard error of this estimate is 17 minutes (i.e., [25 minutes per day worked] $\times$ [249 days worked per year] $\div$ [365 days per year]). For use in the model, this estimate is rounded to $0.8 \pm 0.3$ hours per day.

For the volcanic ash scenario, commuters are assumed to spend 70 minutes per round trip traveling within the contaminated area (Section 5.1). Based on an average workday of 8 hours, this is 48 minutes, or 0.8 hours per day ([70 minutes per day worked] $\times$ [249 days worked per year] $\div$ [365 days per year]). No variation is associated with this value, because it is assumed that commuters drive at least that long to their place of work.

The average commute time for workers in the Amargosa Valley that commuted 35 minutes or less is 22 minutes, with a standard error of 2 minutes (Table 6-8). Based on an average workday of 8 hours, this is 15 minutes, or 0.3 hours per day ([22 minutes per day worked $\times$ [249 days worked per year] $\div$ [365 days per year]). Because the standard error of this estimate is small, it is not incorporated into calculations of activity budgets.

Time Spent Outdoors Not Working-It is estimated that the average amount of time people in the Amargosa Valley spend outdoors in their community while not at work is 1.5 hours per day, with a standard error of 0.2 hours per day. This estimate is developed from a survey of the age distribution of the population in Amargosa Valley and from the NHAPS (Klepeis et al. 1996 [DIRS 159299], EPA 1997 [DIRS 116135]).

For the 1992 to 1994 NHAPS, more than 9,000 people nationwide recorded their activities and locations during a 24-hour period; 6,059 people surveyed were 18 through 64 years old, and 1,349 were 65 years or older (Klepeis et al. 1996 [DIRS 159299], Table 3-9). Weighted percentages of time spent in various environments (Table 6-9) were calculated based on national population characteristics, season, day of week, and other factors (Klepeis et al. 1996 [DIRS 159299], Table 6-1). Note that there is a mistake in the presentation of age groups in Chapter 6 of Klepeis et al. (1996 [DIRS 159299]). The tables incorrectly divide the population 
into the age groups $0-4,5-7,17-64$, and 65+. The correct age groups, as used elsewhere in the report (e.g., Klepeis et al. 1996 [DIRS 159299], p. 4-4), are 0-4, 5-17, 18-64, and 65+.

Table 6-9. Weighted Average Amount of Time Spent Per Day in Various Locations

\begin{tabular}{|c|c|c|c|c|c|c|c|c|}
\hline \multirow[b]{2}{*}{ Location $^{a}$} & \multicolumn{4}{|c|}{ 18-64 Years Old } & \multicolumn{4}{|c|}{$\geq 65$ Years Old } \\
\hline & $\%^{b}$ & Minutes & $\mathrm{SE}^{\mathrm{c}}$ & $n^{d}$ & $\%^{\mathrm{b}}$ & Minutes & $S E^{c}$ & $n^{d}$ \\
\hline Residential Indoors & 64.71 & 932 & 3.5 & 6022 & 80.84 & 1164 & 6.2 & 1348 \\
\hline Residential Outdoors & 2.93 & 42 & 3.6 & 1809 & 4.48 & 65 & 7.5 & 502 \\
\hline In Vehicle & 6.43 & 93 & 1.5 & 5286 & 4.17 & 60 & 3.1 & 907 \\
\hline Travel/Near Vehicle & 2.06 & 30 & 4.0 & 1787 & 0.99 & 14 & 4.6 & 342 \\
\hline Other Outdoor & 2.33 & 34 & 7.3 & 858 & 1.27 & 18 & 16.6 & 118 \\
\hline Office/Factory & 8.42 & 121 & 5.2 & 1749 & 1.18 & 17 & 16.9 & 132 \\
\hline Mall/Other Store & 2.77 & 40 & 3.6 & 1871 & 1.89 & 27 & 4.4 & 397 \\
\hline Public Bldg. & 5.19 & 75 & 5.4 & 1653 & 2.83 & 41 & 6.6 & 385 \\
\hline Bar/Restaurant & 2.43 & 35 & 3.4 & 1718 & 1.27 & 18 & 5.5 & 270 \\
\hline Other Indoor & 2.74 & 39 & 8.1 & 903 & 1.07 & 15 & 14.1 & 128 \\
\hline
\end{tabular}

Sources: Klepeis et al. (1996 [DIRS 159299], Table 6-1); EPA (1997 [DIRS 116135], Tables 15-131 through 15-140).

a Locations defined in Klepeis et al. (1996 [DIRS 159299], Tables 5-2 and 5-3).

b Average percentage of time spend in an environment, weighted based on national population characteristics.

c SE (minutes) for those that spent time in the location on day surveyed, from EPA (1997 [DIRS 116135], Tables 15-131 through 15-140); note that SE for entire population may be much smaller.

d Sample size for SE calculation (i.e., number of people 18 to 64 years old and $\geq 65$ years old surveyed that spent time in a location on the day surveyed; from EPA (1997 [DIRS 116135], Tables 15-131 through 15-140)).

$\mathrm{n}=$ number; $\mathrm{SE}=$ standard error

Klepeis et al. (1996 [DIRS 159299], Table 6-1) classified time spent outdoors per age group into three categories (residential outdoors, near a vehicle, and other outdoors). For this analysis, time spent in these categories was weighted by the percentage of Amargosa Valley residents in each age group during 2000 (721 people 18 through 64 years old, 109 people 65 years or older, Table 6-10).

Table 6-10. Age (years) of Residents of the Amargosa Valley in 2000

\begin{tabular}{|c|c|c|c|c|c|}
\hline Age & $\begin{array}{c}\text { Number of } \\
\text { People }\end{array}$ & Age & $\begin{array}{c}\text { Number of } \\
\text { People }\end{array}$ & Age & $\begin{array}{c}\text { Number of } \\
\text { People }\end{array}$ \\
\hline Under 1 & 13 & 17 & 13 & 45 to 49 & 108 \\
\hline 1 and 2 & 27 & 18 & 39 & 50 to 54 & 96 \\
\hline 3 and 4 & 17 & 19 & 0 & 55 to 59 & 67 \\
\hline 5 & 0 & 20 & 16 & 60 and 61 & 38 \\
\hline 6 & 8 & 21 & 0 & 62 to 64 & 22 \\
\hline 7 to 9 & 41 & 22 to 24 & 49 & 65 to 69 & 37 \\
\hline 10 and 11 & 72 & 25 to 29 & 8 & 70 to 74 & 36 \\
\hline 12 and 13 & 28 & 30 to 34 & 66 & 75 to 79 & 24 \\
\hline 14 & 9 & 35 to 39 & 127 & 80 to 84 & 6 \\
\hline 15 & 65 & 40 to 44 & 85 & 85 and over & 6 \\
\hline 16 & 19 & & & & \\
\hline
\end{tabular}

Source: Bureau of the Census 2002 (DIRS 159728), Table P8. 
- Residential Outdoors-This category includes time spent at a pool, spa, yard, or other time outside one's own house or another house (Klepeis et al. 1996 [DIRS 159299], Tables 5-2 and 5-3). The weighted percentage of time spent in this environment for respondents 18 through 64 years old and 65 years or older was 2.93 percent and 4.48 percent, respectively (Table 6-9). Based on the proportion of people in the Amargosa Valley within each age group, the combined average time spent outdoors for all people 18 years or older is 3.13 percent $([2.93 \% \times 721+4.48 \% \times 109] / 830)$, or 0.75 hours per day.

- Traveling/Near Vehicle (Outdoors)-This category includes time spent on a motorcycle, moped, or scooter; walking; on a bicycle or skateboard; in a stroller or carried by an adult; waiting for a bus, train, or other ride; on a sidewalk, street, or neighborhood; and at a parking lot, service station, or construction site (Klepeis et al. 1996 [DIRS 159299], Tables 5-2 and 5-3). The weighted percentage of time spent in this environment for respondents 18 through 64 years old and 65 years or older was 2.06 percent and 0.99 percent, respectively (Table 6-9). Based on the proportion of people in the Amargosa Valley within each age group, the combined average time spent outdoors for all people 18 years or older is 1.92 percent $([2.06 \% \times 721+0.09 \% \times 109] / 830)$, or 0.46 hours per day.

- Other Outdoors-The other outdoor category includes time spent in a variety of places, such as school grounds, playgrounds, sports stadiums, parks, golf courses, pools, rivers, lakes, outdoor restaurants, picnic areas, and farms (Klepeis et al. 1996 [DIRS 159299], Tables 5-2 and 5-3). The weighted percentage of time spent in these environments for respondents 18 through 64 years old and 65 years or older was 2.33 percent and 1.27 percent, respectively (Table 6-9). Based on the proportion of people in the Amargosa Valley within each age group, the combined average time spent outdoors for all people 18 years or older is 2.19 percent $([2.33 \% \times 721+1.27 \% \times 109] / 830)$, or 0.53 hours per day.

The total time spent in these three environments by people 18 years or older (weighted by the proportion of people in the Amargosa Valley 18-64 and 65 years or older) is 7.24 percent, or 1.74 hours per day. A slightly lower value of 6.25 percent, or 1.5 hours per day, is selected for use in the biosphere model as the average time spent outdoors not working because some of the locations included in the environments are uncommon in the Amargosa Valley (e.g., bus and train stations, sports stadiums) and others are work sites included in other biosphere-model environments (e.g., construction sites and farms).

There is uncertainty associated with the use of the data from the national survey in combination with information from the census survey of the people of Amargosa Valley. For example, people in the rural Amargosa Valley may spend more time outdoors than people in urban areas. In contrast, they may spend less time outdoors, especially during the summer, because of extreme temperatures. In addition, there are slight regional differences in the data that cannot be considered in this analysis because weighted, age-specific results are not presented by region (Klepeis et al. 1996 [DIRS 159299], Table 6-1). There also is uncertainty about whether these categories include all likely non-work time spent outdoors in the Amargosa Valley area.

The only estimates of variation presented for the NHAPS data are for the subsamples of people who spent time in an environment, or “doers" (EPA 1997 [DIRS 116135], Table 15-131 through 15-140). For example, the standard error of time spent at home in the residential outdoor 
environment, for those doers who spent time in that environment, was 3.6 minutes $(n=1,809)$ for ages 18 through 64 and 7.5 minutes $(n=502)$ for those 65 years or older (Table 6-9) (EPA 1997 [DIRS 116135], Table 15-132). The remaining approximately 5,100 people surveyed (total sample of 6,059 + 1,349 minus subsample sizes of 1,809 +502 , Klepeis et al. 1996 [DIRS 159299], Table 3-9) spent no time in that environment on the day surveyed. The standard error for the entire sample would be at least a factor of two smaller because total sample sizes are about four times larger than subsample sizes (compare the square root of 1,801 to the square root of 6,059). Adding 5,100 more responses, all of which have the same value (zero), would further decrease the estimate of variation. Therefore, the standard errors calculated for doers are bounding or extreme estimates of variation around the mean time spent in an environment. The combined bounding estimate of standard error for the three environments for persons 18-64 years old, calculated as the square root of the sum of the squared standard error for each environment (Knoll 1989 [DIRS 161052], p. 88) is 9.1 minutes ([3.6 $\left.6^{2}+4.0^{2}+7.3^{2}\right]^{1 / 2}$ ), or 0.15 hours. The combined estimates for persons 65 years or older is 18.8 minutes, or 0.31 hours. Weighted by the age of people in the Amargosa Valley, the estimate for all persons 18 years or older is 0.2 hours $([0.15 \times 721+0.31 \times 109] / 830)$.

The bounding estimate of standard error, 0.2 hours, based on variation among those who spent time in an environment, is selected for use in the biosphere model. This high value is selected to account for uncertainty in the use of national data on activity budgets with survey data from the residents of Amargosa Valley. See the discussion at the end of this section for additional information about the relative importance of this uncertainty in estimating activity budgets based upon surveys of the residents of Amargosa Valley. In summary, an average of 1.5 hours per day outdoors not working, with a standard error of 0.2 hours, is selected as the estimate of total time spent outdoors while not working.

Time Spent Active Outdoors-It is estimated that an average of 20 percent of time spent outdoors in contaminated areas is spent conducting dust-generating activities and that local outdoor workers spend an average of 50 percent of their work time conducting dust-generating activities.

Table 6-11 shows the average amount of time that more than 5,000 people surveyed nationwide in 1985 (an early version of the NHAPS) spent in the "physical/outdoor" environment and the "other/outdoor" environment, when they spent time in those environments. The percent of total time outdoors spent in physical activity ranged from 10 to 33 percent per age group (from EPA 1997 [DIRS 116135], Table 15-10). Based on the proportion of people in the Amargosa Valley within each age group (Table 6-10), the combined average time spent conducting physical activity while outdoors is 20.1 percent. This value at least bounds, and most likely overestimates, the amount of time people spend conducting dust-generating activities outdoors because it includes time spent conducting activities that resuspend little or no excess soil (e.g., walking on turf or paved surfaces, golfing, and swimming) and it includes activities that would be conducted away from contaminated areas. A proportion of 20 percent, and a relatively large standard error of 0.1 hours (half of the standard error of the total time spent outdoors not working), is selected for the biosphere model to account for uncertainty in the application of this 1985 national data to conditions in the Amargosa Valley. Thus, an average time of $0.3 \pm 0.1$ hours (20 percent of 1.5 hours spent outdoors while not at work) spent active 
outdoors and $1.2 \pm 0.2$ hours spent inactive outdoors while not working is to be used for all population groups.

Table 6-11. Average Minutes Spent Active and Inactive Outdoors by Age Groups in 1985

\begin{tabular}{|c|c|c|c|c|}
\hline Environment & 18-24 Years & 25-44 Years & 45-64 Years & $\geq 65$ Years \\
\hline Physical/Outdoors & 17 & 19 & 7 & 15 \\
\hline Other/Outdoors & 34 & 48 & 60 & 82 \\
\hline Total Outdoors & 51 & 67 & 67 & 97 \\
\hline$\%$ Outdoor Physical & $33.3 \%$ & $28.4 \%$ & $10.4 \%$ & $15.5 \%$ \\
\hline Number of Amargosa Valley Residents ${ }^{a}$ & 104 & 286 & 331 & 109 \\
\hline
\end{tabular}

Source: EPA 1997 (DIRS 116135), Table 15-10.

${ }^{\text {a }}$ From Table 6-10.

It is not reasonable to conclude that local outdoor workers would spend all of their work hours conducting dust-generating activities. Although some workers may spend the majority of their work time conducting dust-generating activities, others would spend little time doing so. For example, some agricultural workers may spend a substantial amount of their time irrigating, spraying pesticides, and conducting other activities that resuspend little soil. Because most fields in Amargosa Valley are planted in alfalfa and other hay (CRWMS M\&O 1997 [DIRS 101090], Tables 3-12 and 3-13; YMP 1999 [DIRS 158212], Tables 10 and 11; Rasmuson 2004 [DIRS 169506]), agricultural workers plow and conduct other soil disturbing activities in those fields infrequently. In addition, many miners and other outdoor workers would be involved in activities (e.g., miners conducting subsurface excavations) that do not resuspend surface soil. Therefore, a value of 50 percent was chosen as the percentage of time that outdoor workers spend conducting dust-generating activities. This is 2.8 hours of an annual average of 5.5 hours spent working per day. A standard error of 0.2 hours (more than half of the total standard error of time spent working) is selected to account for uncertainty in time spent conducting dust-disturbing activities. Local outdoor workers spend the remainder of their work time ( $2.7 \pm 0.2$ hours) in the inactive outdoor environment.

Time Spent Sleeping-The average amount of time people in the Amargosa Valley spend sleeping is estimated to be 8.3 hours per day with a standard error of 0.1 hours.

People 18 through 64 years old surveyed for NHAPS spent an average of 497 minutes (8.3 hours) sleeping or napping (standard error $=1.6$ minutes or 0.03 hours) (EPA 1997 [DIRS 116135], Table 15-83). People 65 years or older slept or napped an average of 517 minutes (8.6 hours) (standard error $=3.2$ minutes or 0.05 hours). These statistics were calculated using data from people who spent time sleeping or napping during the 24-hour period they were surveyed. However, because most people slept or napped at some time during the survey (6,041 of 6,059 people 18 through 64 years old and 1,347 of 1,349 people 65 years or older) (EPA 1997 [DIRS 116135], Table 15-83) the values do not need to be adjusted to account for those not sleeping or napping. Total sample sizes are from Klepeis et al. (1996 [DIRS 159299], Table 3-9).

Based on the proportion of people in the Amargosa Valley within each age group, the combined average time spent sleeping for all people 18 years or older is 8.3 hours 
([496.9 $\times 721+517.1 \times 109] \div 830 \div 60$ minutes). A standard error of 0.1 hours, which is larger than those reported in the study, is selected to account for uncertainty in the application of this data to the population in the Amargosa Valley.

Time Spent Away from the Amargosa Valley-People in the Amargosa Valley are estimated to spend an average of 2.0 hours per day, with a standard error of 0.4 hours per day, out of the Amargosa Valley shopping, on vacation, getting medical attention, or conducting other non-work activities.

The Amargosa Valley is a small community with only a small medical clinic and a few stores, restaurants, entertainment opportunities, or other amenities (Rasmuson 2004 [DIRS 169506]). It is therefore reasonable to conclude that adults spend some time out of the Amargosa Valley obtaining goods and services and while on vacation.

The combined, weighted average percentage of time people 18 through 64 and 65 years or older surveyed for the NHAPS spent in stores, public buildings (including schools, churches, medical facilities), bars and restaurants, and other indoor locations was 13.13 percent (3.2 hours) and 7.06 percent (1.7 hours), respectively (Table 6-9). Although some facilities included in these categories are found in the Amargosa Valley (e.g., churches, small grocery stores, small medical clinic, and a few restaurants), many activities associated with these locations occur outside of the community. The nearest locations to find large shops and larger medical facilities are Pahrump and Las Vegas, which are 0.5 to more than 1 hour away; therefore, most trips will require 2 or more hours.

It is likely that all residents spend some time outside the Amargosa Valley each year on vacation, recreating, or traveling for other reasons. A 7-day trip is about 1.9 percent of a year, or an average of 0.46 hours per day.

To account for the time people spend out of the farming and residential community for entertainment; vacation; and to obtain medical attention, goods, and other services, it is estimated that residents would spend an average of 2 hours per day out of the potentially contaminated area, with a standard error of 0.4 hours. This relatively large standard error was selected to account for uncertainty in applying national data to the behavior of residents of the Amargosa Valley and to account for uncertainty in the size of the area contaminated by volcanic ash (and therefore the amount of time it would take to leave that area).

\subsubsection{Exposure Times Per Population Group}

The following is a summary of the exposure times per population group, based on the information in Sections 6.3.2.1. Lognormal distributions of exposure times are to be used, with minimum and maximum values equal to the upper and lower $99^{\text {th }}$ percentile of the distributions. The arithmetic means and standard error of these distributions are described below, and the distributions are summarized in Table 6-12.

Lognormal distributions are recommended because population distributions of exposure times generally are characterized by most people spending little time conducting an activity or in a location and a few people spending a large amount of time conducting that activity. For 
example, the average time spent outside the residence by 1,809 people ages 18 to 64 that spent time outside of a residence was 144 minutes, the median was 90 minutes, and the $75^{\text {th }}, 90^{\text {th }}$, and $95^{\text {th }}$ percentiles were 199, 360, and 470 minutes, respectively (EPA 1997 [DIRS 116135], Table 15-132). About 4,000 other people surveyed spent no time outside of a residence.

Table 6-12. Daily Exposure Times for Amargosa Valley Population Groups

\begin{tabular}{|c|c|c|c|c|c|c|c|c|}
\hline \multirow{2}{*}{$\begin{array}{c}\text { Population Group } \\
\text { Environment }\end{array}$} & \multicolumn{4}{|c|}{ Groundwater Scenario (hours/day) $^{a}$} & \multicolumn{4}{|c|}{ Volcanic Ash Scenario (hours/day) ${ }^{a}$} \\
\hline & AM & SE & $\operatorname{Min}^{b}$ & $\operatorname{Max}^{b}$ & AM & SE & $\operatorname{Min}^{b}$ & $\operatorname{Max}^{b}$ \\
\hline \multicolumn{9}{|c|}{ Non-Workers } \\
\hline Away & 2.0 & 0.4 & 1.2 & 3.3 & 2.0 & 0.4 & 1.2 & 3.3 \\
\hline Active Outdoors & 0.3 & 0.1 & 0.1 & 0.7 & 0.3 & 0.1 & 0.1 & 0.7 \\
\hline Inactive Outdoors & 1.2 & 0.2 & 0.8 & 1.8 & 1.2 & 0.2 & 0.8 & 1.8 \\
\hline Asleep Indoors & 8.3 & 0.1 & 8.0 & 8.6 & 8.3 & 0.1 & 8.0 & 8.6 \\
\hline Active Indoors ${ }^{c}$ & 12.2 & & & & 12.2 & & & \\
\hline \multicolumn{9}{|c|}{ Commuters } \\
\hline Away & 8.0 & 0.5 & 6.8 & 9.4 & 8.3 & 0.6 & 6.9 & 10.0 \\
\hline Active Outdoors & 0.3 & 0.1 & 0.1 & 0.7 & 0.3 & 0.1 & 0.1 & 0.7 \\
\hline Inactive Outdoors & 1.4 & 0.2 & 1.0 & 2.0 & 2.0 & 0.2 & 1.5 & 2.6 \\
\hline Asleep Indoors & 8.3 & 0.1 & 8.0 & 8.6 & 8.3 & 0.1 & 8.0 & 8.6 \\
\hline Active Indoors ${ }^{c}$ & 6.0 & & & & 5.1 & & & \\
\hline \multicolumn{9}{|c|}{ Local Outdoor Workers } \\
\hline Away & 2.0 & 0.4 & 1.2 & 3.3 & 2.0 & 0.4 & 1.2 & 3.3 \\
\hline Active Outdoors & 3.1 & 0.2 & 2.6 & 3.7 & 3.1 & 0.2 & 2.6 & 3.7 \\
\hline Inactive Outdoors & 4.0 & 0.3 & 3.3 & 4.8 & 4.2 & 0.3 & 3.5 & 5.0 \\
\hline Asleep Indoors & 8.3 & 0.1 & 8.0 & 8.6 & 8.3 & 0.1 & 8.0 & 8.6 \\
\hline Active Indoors ${ }^{c}$ & 6.6 & & & & 6.4 & & & \\
\hline \multicolumn{9}{|c|}{ Local Indoor Workers } \\
\hline Away & 2.0 & 0.4 & 1.2 & 3.3 & 2.0 & 0.4 & 1.2 & 3.3 \\
\hline Active Outdoors & 0.3 & 0.1 & 0.1 & 0.7 & 0.3 & 0.1 & 0.1 & 0.7 \\
\hline Inactive Outdoors & 1.3 & 0.2 & 0.9 & 1.9 & 1.5 & 0.2 & 1.1 & 2.1 \\
\hline Asleep Indoors & 8.3 & 0.1 & 8.0 & 8.6 & 8.3 & 0.1 & 8.0 & 8.6 \\
\hline Active Indoors ${ }^{c}$ & 12.1 & & & & 11.9 & & & \\
\hline
\end{tabular}

For the lognormal distribution, the lower and upper bounds of the 99 percent confidence interval of the mean are calculated using formulas based on LaPlante and Poor (1997 [DIRS 101079], p. 3-12), where the number of standard deviations for a 99 percent confidence interval is 2.576 (Lide and Frederikse 1997 [DIRS 103178], p. A-104), such that

$$
\begin{aligned}
\text { lower bound } & =\frac{G M}{G S D^{2.576}} \\
\text { upper bound } & =G M \times G S D^{2.576}
\end{aligned}
$$


where

$$
\begin{array}{ll}
G M & =\text { geometric mean } \\
G S D & =\text { geometric standard deviation }
\end{array}
$$

The geometric mean and geometric standard deviation are calculated as

$$
\begin{aligned}
& G M=e^{\lambda} \\
& G S D=e^{\zeta}
\end{aligned}
$$

with the variance of $\ln (x)$ for the lognormal distribution, $\zeta$, given by Golder Associates (2000 [DIRS 146973], p. B-3), as

$$
\zeta^{2}=\ln \left[1+\left(\frac{S E}{\bar{X}}\right)^{2}\right]
$$

and the expected value of $\ln (x), \lambda$, is

$$
\lambda=\ln (\bar{X})-\frac{1}{2} \zeta^{2}
$$

For cases in which more than one activity must be summed to obtain an average time (e.g., total time out of the contaminated environment includes commuting time and time spent away from the Amargosa Valley), the standard error of the total average time is calculated as the square root of the sum of squared standard error values per activity (Knoll 1989 [DIRS 161052], p. 88).

Non-Workers-Non-workers spend an average of $2.0 \pm 0.4$ hours per day out of the potentially contaminated area conducting non-work activities, $0.3 \pm 0.1$ hours per day active outdoors, $1.2 \pm 0.2$ hours per day inactive outdoors conducting non-work activities, and $8.3 \pm 0.1$ hours sleeping. The average time spent indoors by non-workers is 12.2 hours per day (24 hours minus 2.0 hours away, 0.3 hours active outdoors, 1.2 hours inactive outdoors, and 8.3 hours sleeping).

Commuters-For the groundwater scenario, commuters spend an average of $8.0 \pm 0.5$ hours per day out of the contaminated area, including time spent working (5.5 \pm 0.3 hours per day), commuting ( $0.5 \pm 0.1$ hours per day), and conducting non-work activities $(2.0 \pm 0.4$ hour per day), with the standard error calculated as $\left[0.3^{2}+0.1^{2}+0.4^{2}\right]^{1 / 2}=0.51$. Commuters spend an average of $0.3 \pm 0.1$ hours per day active outdoors. They spend an average of $1.4 \pm 0.2$ hours per day inactive in the outdoor environment, including 0.2 hours per day commuting within the area assumed to be contaminated by groundwater and an additional $1.2 \pm 0.2$ hours inactive outdoors while not working. It is estimated that commuters spend $8.3 \pm 0.1$ hours per day sleeping. The average time spent active indoors within the contaminated area is 6.0 hours per day (24 hours minus 8.0 hours away, 0.3 hours active outdoors, 1.4 hours inactive outdoors, and 8.3 hours sleeping).

For the volcanic ash scenario, commuters spend an average of $8.3 \pm 0.6$ hours per day out of the contaminated area, including time spent working ( $5.5 \pm 0.3$ hours per day), commuting ( $0.8 \pm 0.3$ 
hours per day), and conducting non-work activities (2.0 \pm 0.4 hour per day), with the standard error calculated as $\left[0.3^{2}+0.3^{2}+0.4^{2}\right]^{1 / 2}=0.58$. They spend an average of $0.3 \pm 0.1$ hours per day active outdoors. They spend an average of $2.0 \pm 0.2$ hours per day inactive in the outdoor environment, including 0.8 hours per day commuting within the area assumed to be contaminated by ash, and an additional $1.2 \pm 0.2$ hours inactive outdoors while not working. It is estimated that commuters spend $8.3 \pm 0.1$ hours per day sleeping. The average time spent active indoors within the contaminated area is 5.1 hours per day (24 hours minus 8.3 hours away, 0.3 hours active outdoors, 2.0 hours inactive outdoors, and 8.3 hours sleeping).

Local Outdoor Workers-For the groundwater scenario, local outdoor workers spend an average of $2.0 \pm 0.4$ hours per day out of the potentially contaminated area conducting non-work activities. They spend $3.1 \pm 0.2$ hours per day active outdoors, including $2.8 \pm 0.2$ hours active outdoors while working and $0.3 \pm 0.1$ hours active outdoors conducting non-work activities. They spend an average of $4.0 \pm 0.3$ hour per day in the inactive outdoor environment, including $2.7 \pm 0.2$ hours working, 0.1 hours commuting, and $1.2 \pm 0.2$ hours conducting non-work activities. Local outdoor workers spend $8.3 \pm 0.1$ hours per day sleeping. Thus, the average time spent active indoors by local outdoor workers is 6.6 hours per day (24 hours minus 2 hours away, 3.1 hours active outdoors, 4.0 hours inactive outdoors, and 8.3 hours sleeping).

All exposure times are the same for the volcanic ash scenario except the time local outdoor workers commute ( 0.3 hours). Thus, they spend an average of $4.2 \pm 0.3$ hour per day in the inactive outdoor environment, and an average of 6.4 hours per day active indoors.

Local Indoor Workers-For the groundwater scenario, local indoor workers spend $2.0 \pm 0.4$ hours per day out of the contaminated area conducting non-work activities. They spend an average of $0.3 \pm 0.1$ hours per day active outdoors. They spend $1.3 \pm 0.2$ hour per day in the inactive outdoor environment, including 0.1 hours commuting and $1.2 \pm 0.2$ hours conducting non-work activities. Average time spent active indoors by local indoor workers is 12.1 hours (24 hours minus 2.0 hours away, 0.3 hours active outdoors, 1.3 hours inactive outdoors, and 8.3 hours sleeping). This estimate of 12.1 hours includes an average of 5.5 hours working indoors.

All exposure times are the same for the volcanic ash scenario except for the time local indoor workers commute ( 0.3 hours). Thus, they spend an average of $1.5 \pm 0.2$ hour per day in the inactive outdoor environment and an average of 11.9 hours per day active indoors.

Information on time budgets of the people of Amargosa Valley was not collected because it would require very intrusive data collection and because the information that would be gathered would not contribute in an important way to the understanding of the lifestyle of the RMEI and would not result in underestimating risk.

To meet the requirements of 10 CFR 63.312 that average values of lifestyle characteristics of the residents of Amargosa Valley be used in the TSPA dose assessments, the average exposure time per environment is calculated in the biosphere model as the average of exposure times per group weighted by the proportion of the population in each group (BSC 2004 [DIRS 169460], Section 6.4.7.1). This estimate of a lifestyle characteristic is based on a survey of the employment status, time worked, and commute time of the people of Amargosa Valley (Bureau 
of the Census 2002 [DIRS 159728]). This information on employment characteristics has the greatest influence on variation in activity budgets and exposure rates because work status and location determines what people will be doing and where they will be doing it during the time of day when most people are away from their home. During the remainder of the day most people will be conducting similar activities such as sleeping or remaining in or near their residences.

Information from national surveys of activity budgets was used in combination with survey data from the people of Amargosa Valley to estimate time sleeping and time spent outdoors and away from potentially contaminated areas while not working. Surveys of the people of Amargosa Valley were not conducted to obtain this activity-budget information because it would not have contributed substantially to the measurement of uncertainty in this lifestyle characteristic and would have required a very intrusive investigation of Amargosa Valley residents. For example, the standard error of the average time spent sleeping measured in the NHAPS was about 3 minutes. This small amount of variation has no influence on estimates of time budgets. In addition, there is little variation in the average time that people spend sleeping and no reason to expect that people in Amargosa Valley have, on average, different sleep habits than people elsewhere in the United States. Times spent outdoors and away from the area are a relatively small part of a day (about 3.5 hours). Because most people in Amargosa Valley would spend at least some time in those environments, the uncertainty in the estimates used is a matter of minutes, not hours, and has little influence on estimates of time budgets. It is therefore concluded that the population proportions and activity budgets are based upon a survey of the residents of the town of Amargosa Valley.

\subsubsection{Breathing Rates}

Breathing rates used in the biosphere model represent the average values for each population group within the four potentially contaminated environments used in the ERMYN model (Section 6.2). The breathing rate for a population group in an environment is determined by considering the fraction of time people in that group are involved in various levels of activity and the breathing rate associated with those activity levels. Uncertainty in breathing rates is associated with the accuracy of estimates of activity levels for each population group and with the accuracy of measurements of breathing rates for these activity levels (ICRP 1994 [DIRS 153705], p. 198).

The expected values of breathing rates for the biosphere model were developed using values from ICRP Publication 66 (ICRP 1994 [DIRS 153705]). To comply with the requirement of 10 CFR 63.312(e) that the RMEI be an adult, breathing rates representative of adults were selected for this analysis. The activity levels considered in this analysis correspond to activity levels used in ICRP Publication 66: sleep, sitting, light exercise, and heavy exercise (ICRP 1994 [DIRS 153705], p. 192). Light exercise corresponds to working, for example, in workshops, active housecleaning, painting, or woodworking. Heavy exercise is considered appropriate for construction workers, farm workers, firemen, and athletes. ICRP Publication 66 assigns a standard combination of activity levels to the typical groups of people and typical environments (ICRP 1994 [DIRS 153705], p. 193).

Four environments in the contaminated area are considered in the biosphere model: active outdoors, inactive outdoors, active indoors (i.e., not sleeping) and asleep (Section 6.3.2). People 
from all four groups (Section 6.3.1) could spent some of their time in any of these environments, either working, recreating, doing house work, resting, or involved in other activities. To develop expected values of breathing rates for the biosphere model, the amount of time spent in various equivalent environments was taken from the recent ICRP recommendations in the respiratory tract model (ICRP 1994 [DIRS 153705]), in which the nominal mix of activity levels associated with different environments is defined. These values were adopted for the environments used in the biosphere model as shown in Table 6-13.

Table 6-13. Contributions of Activity Levels by Population Group and Environment

\begin{tabular}{|c|c|c|c|c|}
\hline $\begin{array}{c}\text { Population } \\
\text { Group, } \\
\text { Environment }\end{array}$ & Commuters & $\begin{array}{c}\text { Local Outdoor } \\
\text { Workers }\end{array}$ & $\begin{array}{l}\text { Local Indoor } \\
\text { Workers } \\
\text { (Sedentary) }\end{array}$ & Non-workers \\
\hline \multirow{2}{*}{ Active outdoors } & $\begin{array}{l}\text { At work: } \\
\text { N/A }\end{array}$ & $\begin{array}{l}\text { At work: } \\
\text { 7/8 light exercise } \\
\text { 1/8 heavy exercise }\end{array}$ & $\begin{array}{l}\text { At work: } \\
\text { N/A }\end{array}$ & $\begin{array}{l}\text { At work: } \\
\text { N/A }\end{array}$ \\
\hline & $\begin{array}{l}\text { Recreation/Other: } \\
\text { 7/8 light exercise } \\
\text { 1/8 heavy exercise }\end{array}$ & $\begin{array}{l}\text { Recreation/Other: } \\
\text { 7/8 light exercise } \\
\text { 1/8 heavy exercise }\end{array}$ & $\begin{array}{l}\text { Recreation/Other: } \\
\text { 7/8 light exercise } \\
\text { 1/8 heavy exercise }\end{array}$ & $\begin{array}{l}\text { Recreation/Other: } \\
\text { 7/8 light exercise } \\
\text { 1/8 heavy exercise }\end{array}$ \\
\hline \multirow{2}{*}{ Inactive outdoors } & $\begin{array}{l}\text { At work: } \\
\text { N/A }\end{array}$ & $\begin{array}{l}\text { At work: } \\
\text { 1/3 sitting } \\
\text { 2/3 light exercise }\end{array}$ & $\begin{array}{l}\text { At work: } \\
\text { N/A }\end{array}$ & $\begin{array}{l}\text { At work: } \\
\text { N/A }\end{array}$ \\
\hline & $\begin{array}{l}\text { Recreation/Other: } \\
\text { 1/3 sitting } \\
\text { 2/3 light exercise }\end{array}$ & $\begin{array}{l}\text { Recreation/Other: } \\
\text { 1/3 sitting } \\
\text { 2/3 light exercise } \\
\end{array}$ & $\begin{array}{l}\text { Recreation/Other: } \\
\text { 1/3 sitting } \\
\text { 2/3 light exercise }\end{array}$ & $\begin{array}{l}\text { Recreation/Other: } \\
\text { 1/3 sitting } \\
\text { 2/3 light exercise }\end{array}$ \\
\hline \multirow{2}{*}{ Active indoors } & $\begin{array}{l}\text { At work: } \\
\text { N/A }\end{array}$ & $\begin{array}{l}\text { At work: } \\
\text { N/A }\end{array}$ & $\begin{array}{l}\text { At work: } \\
\text { 1/3 sitting } \\
\text { 2/3 light exercise }\end{array}$ & $\begin{array}{l}\text { At work: } \\
\text { N/A }\end{array}$ \\
\hline & $\begin{array}{l}\text { At home: } \\
\text { 1/3 sitting } \\
\text { 2/3 light exercise }\end{array}$ & $\begin{array}{l}\text { At home: } \\
\text { 1/3 sitting } \\
\text { 2/3 light exercise } \\
\end{array}$ & $\begin{array}{l}\text { At home: } \\
\text { 1/3 sitting } \\
\text { 2/3 light exercise }\end{array}$ & $\begin{array}{l}\text { At home: } \\
\text { 1/3 sitting } \\
\text { 2/3 light exercise }\end{array}$ \\
\hline Asleep indoors & Sleeping & Sleeping & Sleeping & Sleeping \\
\hline
\end{tabular}

Source: ICRP 1994 (DIRS 153705), p. 193, Tables B.16B, and B.17.

The breathing rates in ICRP Publication 66 (ICRP 1994 [DIRS 153705], p. 197) are calculated using the following mix of activity levels: $1 / 3$ sitting $+2 / 3$ light exercise for the time spent indoors not sleeping (corresponding to the active indoors environment of the biosphere model); $1 / 2$ sitting $+3 / 8$ light exercise $+1 / 8$ heavy exercise for travel and sports; and 7/8 light exercise + $1 / 8$ heavy exercise for outdoor workers. In the biosphere model, the time spent recreating outdoors is divided into two environments, active and inactive. Therefore, the activity mix that corresponds to the ICRP travel and sports category was not used. Rather, the breathing rate associated with the outdoor workers (7/8 light exercise $+1 / 8$ heavy exercise) was used for active recreation outdoors and the breathing rate associated with the active indoor environment (1/3 sitting $+2 / 3$ light exercise) was used for the inactive recreation outdoors.

Activity-level dependent breathing rates for the biosphere model (Table 6-14) were calculated using data from ICRP Publication 66 (ICRP 1994 [DIRS 153705]) and gender weights consistent 
with the 2000 Census results; that is, 52.2 percent for males 18 years old or older and 47.8 percent for females 18 years old or older (Bureau of the Census 2002 [DIRS 159728], Table P8).

Table 6-14. Breathing Rates Per Level of Activity

\begin{tabular}{|l|c|c|c|c|}
\hline \multirow{2}{*}{\multicolumn{1}{|c|}{ Gender }} & \multicolumn{4}{|c|}{ Breathing Rate for a Given Exercise Level, $\mathbf{~ m}^{\mathbf{3}} \mathbf{h r}$} \\
\cline { 2 - 5 } & Sleep & Sitting & Light Exercise & Heavy Exercise \\
\hline Adult woman & 0.32 & 0.39 & 1.25 & 2.7 \\
\hline Adult man & 0.45 & 0.54 & 1.5 & 3.0 \\
\hline Adult ICRP-Amargosa Valley $^{\mathrm{a}}$ & 0.39 & 0.47 & 1.38 & 2.86 \\
\hline
\end{tabular}

Source: ICRP 1994 (DIRS 153705), p. 24.

${ }^{a}$ Calculated by producing the weighted average of the breathing rates for males and females using the weights based on the fraction of males and females derived from the 2000 Census information (Bureau of the Census 2002 [DIRS 159728], Table P8).

When the activity level information (Table 6-13) is combined with the breathing rates for the Amargosa Valley population (Table 6-14), the expected values of effective breathing rates for the population groups and for the environments can be calculated (Table 6-15).

The values of breathing rates shown in Table 6-15 are recommended for the use in the biosphere model.

Table 6-15. Calculation of Expected Breathing Rates

\begin{tabular}{|c|c|}
\hline Environment & Breathing Rate for All Population Groups $^{a}$ \\
\hline Active outdoors & $7 / 8 \times 1.38 \mathrm{~m}^{3} / \mathrm{hr}+1 / 8 \times 2.86 \mathrm{~m}^{3} / \mathrm{hr}=1.57 \mathrm{~m}^{3} / \mathrm{hr}^{\mathrm{b}}$ \\
\hline Inactive outdoors & $1 / 3 \times 0.47 \mathrm{~m}^{3} / \mathrm{hr}+2 / 3 \times 1.38 \mathrm{~m}^{3} / \mathrm{hr}=1.08 \mathrm{~m}^{3} / \mathrm{hr}^{\mathbf{b}}$ \\
\hline Active indoors & $1 / 3 \times 0.47 \mathrm{~m}^{3} / \mathrm{hr}+2 / 3 \times 1.38 \mathrm{~m}^{3} / \mathrm{hr}=1.08 \mathrm{~m}^{3} / \mathrm{hr}^{\mathbf{b}}$ \\
\hline Asleep indoors & $0.39 \mathrm{~m}^{3} / \mathrm{hr}$ \\
\hline
\end{tabular}

NOTE: For the activity mix consisting of $1 / 2(50 \%)$ time spent sitting, $3 / 8(38 \%)$ in light exercise, and $1 / 8(13 \%)$ in heavy exercise, which is recommended by ICRP (ICRP 1994 [DIRS 153705], p. 197) for outdoor travel, sports, etc, the breathing rate would be $1.11 \mathrm{~m}^{3} / \mathrm{hr}$, which is practically the same as that the value calculated for the biosphere model for the inactive outdoors and active indoors environments.

a Commuters, local outdoor workers, local indoor workers, non-workers.

b The results were rounded off to three significant figures.

The remainder of this section presents an evaluation of how the breathing rates calculated using the ICRP-recommended mix of activity levels compare with the breathing rates that would be obtained if the national survey data were used instead. The fractional contributions of activity levels listed in Table 6-13 were compared with the aggregated results of the national survey (EPA 1997 [DIRS 116135], Table 15-9) listed in Table 6-16. The survey investigated the amount of time spent by people in various microenvironments. The time spent in various activities was divided among the environment-activity level categories as indicated in Table 6-16. The percentage of time spent in a given environment at a given activity level was then calculated by taking the weighted averages of the percent time spent on week days and on weekends with weighting factors corresponding to the number of week days and weekend days. 
Table 6-17 compares the percent of time spent in various environments at different activity levels calculated from the national survey data (Table 6-16) with the values adopted for the biosphere model calculated based on ICRP recommendations (Table 6-13).

Table 6-16. Calculation of Aggregated Times Spent in Environments Per Activity Level

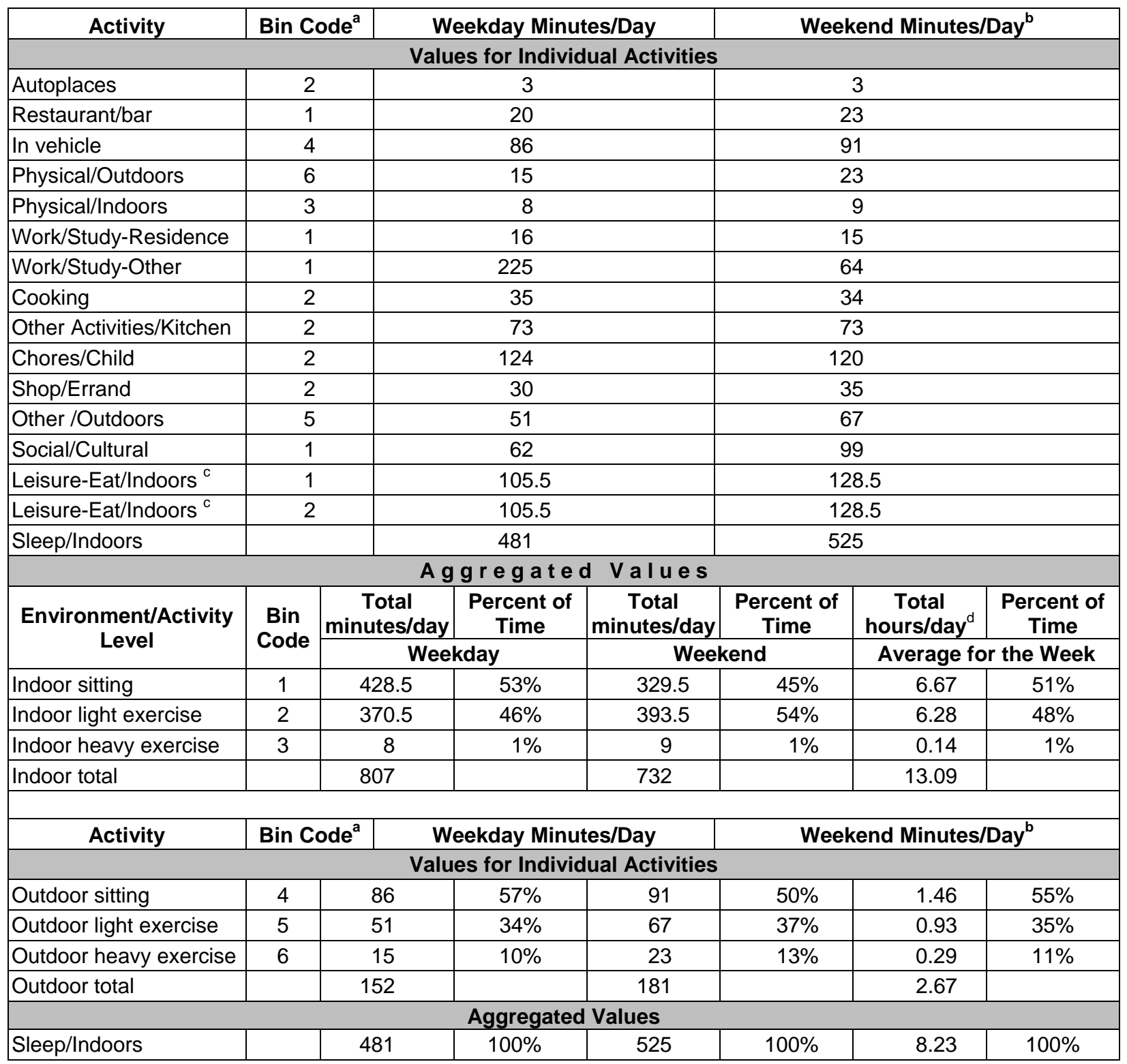

Source: EPA 1997 (DIRS 116135), Table 15-9.

NOTE: The data are for sample population ages 12 years and older. The biosphere model applies to adults (18 years and older). However, these data are presented here for comparison only (not used to develop the values of model parameters) and are considered to sufficiently represent times spent in various activities for adult population.

${ }^{a}$ Bin code corresponds to the designation of activity level and environment used for aggregation.

b Weekend minutes do not add up to 1440 minutes per day due to rounding.

${ }^{c}$ Leisure-Eat/Indoors time was split evenly between indoor sitting and indoor light exercise categories.

d Weighted averages for a week. 
Table 6-17. Percent of Time Spent Outdoors and Indoors Per Activity Level

\begin{tabular}{|c|c|c|c|c|c|}
\hline \multirow[b]{2}{*}{ Environment } & \multicolumn{3}{|c|}{ Activity Level } & \multirow[b]{2}{*}{$\begin{array}{c}\text { Breathing } \\
\text { rate }^{\mathrm{a}}\end{array}$} & \multirow[b]{2}{*}{ Reference } \\
\hline & Sitting & $\begin{array}{c}\text { Light } \\
\text { Exercise }\end{array}$ & $\begin{array}{c}\text { Heavy } \\
\text { Exercise }\end{array}$ & & \\
\hline Outdoors active & $0 \%$ & $87.5 \%$ & $12.5 \%$ & $1.57 \mathrm{~m}^{3} / \mathrm{hr}$ & $\begin{array}{l}\text { Values adopted for the biosphere } \\
\text { model based on ICRP } 1994 \\
\text { (DIRS 153705), pp. } 24 \text { and } 197 .\end{array}$ \\
\hline Outdoors inactive & $33 \%$ & $67 \%$ & $0 \%$ & $1.08 \mathrm{~m}^{3} / \mathrm{hr}$ & $\begin{array}{l}\text { Values adopted for the biosphere } \\
\text { model based on ICRP } 1994 \\
\text { (DIRS 153705), pp. } 24 \text { and } 197 .\end{array}$ \\
\hline $\begin{array}{l}\text { Outdoor active and } \\
\text { inactive }\end{array}$ & $55 \%^{b}$ & $35 \%$ & $11 \%$ & $1.06 \mathrm{~m}^{3} / \mathrm{hr}$ & $\begin{array}{l}\text { Aggregated results based on Robin } \\
\text { and Thomas 1991, as cited in EPA } \\
1997 \text { (DIRS 116135), Table 15-9. }\end{array}$ \\
\hline \multirow{2}{*}{ Indoors active } & $33 \%$ & $67 \%$ & $0 \%$ & $1.08 \mathrm{~m}^{3} / \mathrm{hr}$ & $\begin{array}{l}\text { Values adopted for the biosphere } \\
\text { model based on ICRP } 1994 \\
\text { (DIRS 153705), pp. } 24 \text { and } 197 .\end{array}$ \\
\hline & $51 \%$ & $48 \%$ & $1 \%$ & $0.93 \mathrm{~m}^{3} / \mathrm{hr}$ & $\begin{array}{l}\text { Aggregated results based on EPA } \\
1997 \text { (DIRS 116135), Table 15-9. }\end{array}$ \\
\hline Asleep Indoors & N/A & $\mathrm{N} / \mathrm{A}$ & $\mathrm{N} / \mathrm{A}$ & $0.39 \mathrm{~m}^{3} / \mathrm{hr}$ & $\begin{array}{l}\text { Values adopted for the biosphere } \\
\text { model based on ICRP } 1994 \\
\text { (DIRS 153705), p. } 24 .\end{array}$ \\
\hline
\end{tabular}

${ }^{a}$ Calculated using the breathing rates for adults of both genders from Table 6-14.

${ }^{\mathrm{b}}$ Percentages do not total to 100 percent because of the rounding.

Compared with the results of the national survey, the values adopted for the biosphere model for the outdoor and indoor environments are based on less time spent sitting and more time spent at light or higher levels of activity. However, the difference in breathing rates per environment is slight (Table 6-17). For the outdoor environment, the national survey results were combined into one environment, while the biosphere model uses two outdoor environments. The results (Table 6-17) indicate that the values of breathing rates selected for the biosphere model are slightly more conservative than what would be suggested by the results of the national survey. However, there is some degree of ambiguity in determining the breathing rates corresponding to the aggregated results of the national survey because the aggregation of activities listed in Table 6-16 involved categorizing the listed activities into the indoor and outdoor categories and activity levels. Therefore, it is concluded that the values of the environment-specific breathing rates selected for the biosphere model appropriately describe the expected combination of exercise levels.

\subsubsection{Evaporative Cooler Use}

There are two parameters in the biosphere model that quantify the use of evaporative coolers. These are the fraction of houses with evaporative coolers and the annual evaporative cooler use factor. For houses that are equipped with evaporative coolers, the evaporative cooler use factor is the fraction of a year that an evaporative cooler is used. The fraction of houses with evaporative coolers is representative of the living style of the residents of Amargosa Valley and therefore was developed based on a survey of those residents. The evaporative cooler use factor was developed based on a survey of the residents of Amargosa Valley and the present-day and predicted future climatic conditions in the Yucca Mountain region. 


\subsubsection{Fraction of Houses with Evaporative Coolers}

One of the questions asked during the regional survey of Amargosa Valley residents (DOE 1997 [DIRS 100332], p. B-12) was: "Do you use a swamp cooler to cool your home during any part of the year?" Of 187 full time adult residents of the Amargosa Valley who participated in the survey, 138 (73.8 percent) responded yes, and 49 responded no. Therefore, the estimated proportion of households that used evaporative coolers is 0.738. This proportion was calculated using the information from the data set DTN: MO0010SPANYE00.001 [DIRS 154976]. These calculations were performed using Excel (Appendix C, Consumption rates with uncertainties.xls).

Because the applicable responses to this question were yes and no, the binomial distribution was selected to represent uncertainty in the sampling results. The binomial distribution is generally applied when the result is one of a small number of possible final states (Bevington and Robinson 1992 [DIRS 147076], p. 17), which fits the case of using an evaporative cooler. The biosphere model requires two inputs for a binomial distribution, the probability and a batch size. The probability is 0.738 , based on 73.8 percent of people surveyed in Amargosa Valley having evaporative coolers) and the batch (sample) size is 187. The resulting distribution is presented in units of households, with a mean of $138(187 \times 0.738)$. Because the biosphere model uses the fraction of houses that used evaporative coolers rather than the number of houses, the sampled value must be divided by the batch size of 187 .

\subsubsection{Evaporative Cooler Use Factor}

The evaporative cooler use factor was determined from a combination of local survey data and information on present-day and predicted future climatic conditions in the Yucca Mountain region. As part of the regional survey of Amargosa Valley residents, people who responded that they used a swamp cooler were asked "how many months each year do you normally run your swamp cooler” (DOE 1997 [DIRS 100332], p. B-12; DTN: MO0010SPANYE00.001 [DIRS 154976]). Responses ranged from 1 to 12 months a year (Figure 6-2), with an average of 5.9 months (49\% of the year) and a standard error of 0.14 months (the figure and summary statistics are from the Excel spreadsheet Consumption rates with uncertainties.xls in Appendix C). Figure 6-2 is based on 187 full time adult residents of the Amargosa Valley who participated in the survey. The standard error was calculated as the ratio of standard deviation and the square root of the number of surveyed households equipped with an evaporative cooler.

An additional analysis was conducted using maximum daily temperatures because the survey data cannot be used to predict evaporative cooler use for the future climate. In addition, the survey results are not very precise because people were asked how many months, rather than days, a cooler was run, and the survey did not clarify whether respondents ran their cooler without water for part of the year. The fact that some respondents reported running their coolers for 10 to 12 months indicates that some respondents may have included the time that cooler fans were run with the water pump turned off to provide home ventilation.

The evaporative cooler use factor was calculated as the proportion of days per year that the daily maximum outside temperature exceeded a threshold level above which people were likely to cool their homes. Three threshold levels were used to account for uncertainty in the range of 
temperatures over which people are likely to operate an evaporative cooler: $80^{\circ} \mathrm{F}\left(26.7^{\circ} \mathrm{C}\right), 85^{\circ} \mathrm{F}$ $\left(29.4^{\circ} \mathrm{C}\right)$, and $90^{\circ} \mathrm{F}\left(32.2^{\circ} \mathrm{C}\right)$. The lower limit of the range corresponds to the upper limit of the comfort zone for a relative humidity of about 20 percent (Watt and Brown 1997 [DIRS 159497], p. 33). The relative humidity of 20 percent corresponds well to the mean values measured at Site 9 on the Nevada Test Site during the summer months (CRWMS M\&O 1999 [DIRS 102877], p. A-10). Therefore, when the outdoor temperature reaches $80^{\circ} \mathrm{F}\left(26.7^{\circ} \mathrm{C}\right)$ it is possible, but not likely that people would turn on their coolers. Also, they probably would not run them for the whole day because during most of the day the temperature would be lower than $80^{\circ} \mathrm{F}$ $\left(26.7^{\circ} \mathrm{C}\right)$. The upper limit of the range is $10^{\circ} \mathrm{F}$ higher, which is approximately the width (range) of the temperature comfort zone (Watt and Brown 1997 [DIRS 159497], p. 33). It is assumed in the biosphere model (BSC 2004 [DIRS 169460], Section 5) that the indoor concentration of airborne contaminants resulting from operation of a cooler persists throughout the day, even for those days when the cooler is operated for only a portion of the day.

For the present-day climate, the evaporative cooler use factor was calculated using temperatures measured at Yucca Mountain Meteorological Monitoring Site 9 (Section 4.1.6). Data from the four years preceding and including the survey year (1994 through 1997) were used to calculate the number of days per year that the daily maximum temperature exceeded threshold values (Table 6-18), as documented in BSC (2004 [DIRS 167055], Section 6.2). Based on these results, it is recommended that the evaporative cooler use factor for the present-day climate be represented by the uniform distribution in the range from 0.32 to 0.46 .

Data from a weather station at Spokane, Washington, were used to calculate the evaporative cooler use factor for the future climate. This site is representative of the upper bound (i.e., cooler and wetter) of the glacial-transition climate state predicted to occur at Yucca Mountain in the future (BSC 2004 [DIRS 170002], Table 6-1). The data were obtained from the National Climatic Data Center (NCDC [n.d.] [DIRS 161091]). Data from six years (1990-1995) were used to calculate the number of days per year that the daily maximum temperature exceeded threshold values (Table 6-19). The Excel data are listed in Appendix C, Spokane Hourly Temperatures and Daily Max Temperatures.xls. Based on this information, it is recommended that the evaporative cooler use factor for the glacial transition climate be represented by the uniform distribution in the range from 0.03 to 0.14 .

Table 6-18. Evaporative Cooler Use Factor for the Present-Day Climate

\begin{tabular}{|c|c|c|c|c|c|c|}
\hline \multirow[b]{2}{*}{ Year } & \multicolumn{2}{|c|}{$>80^{\circ} \mathrm{F}\left(>26.7^{\circ} \mathrm{C}\right)$} & \multicolumn{2}{|c|}{$>85^{\circ} \mathrm{F}\left(>29.4^{\circ} \mathrm{C}\right)$} & \multicolumn{2}{|c|}{$>90^{\circ} \mathrm{F}\left(>32.2^{\circ} \mathrm{C}\right)$} \\
\hline & $\mathrm{N}_{\text {days }}{ }^{a}$ & Use Factor $^{b}$ & $N$ days ${ }^{a}$ & Use Factor $^{b}$ & N days $^{a}$ & Use Factor ${ }^{b}$ \\
\hline 1994 & 161 & 0.44 & 142 & 0.39 & 124 & 0.34 \\
\hline 1995 & 154 & 0.42 & 131 & 0.36 & 103 & 0.28 \\
\hline 1996 & 172 & 0.47 & 149 & 0.41 & 126 & 0.34 \\
\hline 1997 & 179 & 0.49 & 150 & 0.41 & 117 & 0.32 \\
\hline Average & 167 & $0.46 \pm 0.03$ & 143 & $0.39 \pm 0.02$ & 118 & $0.32 \pm 0.03$ \\
\hline
\end{tabular}

Source: DTN: MO04019SUM9397.000 (DIRS 167054).

a Number of days per year that daily maximum temperature exceeded threshold temperature.

${ }^{b}$ Percentage of days per year that daily maximum temperatures exceeded threshold temperature. 
Table 6-19. Evaporative Cooler Use Factor for the Upper Bound Glacial Transition Climate

\begin{tabular}{|c|c|c|c|c|c|c|}
\hline \multirow[b]{2}{*}{ Year } & \multicolumn{2}{|c|}{$>80^{\circ} \mathrm{F}\left(>26.7^{\circ} \mathrm{C}\right)$} & \multicolumn{2}{|c|}{$>85^{\circ} \mathrm{F}\left(>29.4^{\circ} \mathrm{C}\right)$} & \multicolumn{2}{|c|}{$>90^{\circ} \mathrm{F}\left(>32.2^{\circ} \mathrm{C}\right)$} \\
\hline & $\mathbf{N}$ days $^{a}$ & Use Factor ${ }^{b}$ & $\mathbf{N}$ days ${ }^{a}$ & Use Factor ${ }^{b}$ & $\mathrm{~N}_{\text {days }}{ }^{\mathrm{a}}$ & Use Factor ${ }^{b}$ \\
\hline 1990 & 59 & 0.16 & 40 & 0.11 & 15 & 0.04 \\
\hline 1991 & 48 & 0.13 & 25 & 0.07 & 12 & 0.03 \\
\hline 1992 & 56 & 0.15 & 40 & 0.11 & 19 & 0.05 \\
\hline 1993 & 32 & 0.09 & 12 & 0.03 & 1 & 0.00 \\
\hline 1994 & 67 & 0.18 & 41 & 0.11 & 20 & 0.05 \\
\hline 1995 & 47 & 0.13 & 18 & 0.05 & 3 & 0.01 \\
\hline Average & 52 & $0.14 \pm 0.03$ & 29 & $0.08 \pm 0.04$ & 12 & $0.03 \pm 0.02$ \\
\hline
\end{tabular}

Source: NCDC [n.d.] (DIRS 161091).

${ }^{a}$ Number of days per year that daily maximum temperatures exceeded threshold temperature.

${ }^{b}$ Percentage of days per year that daily maximum temperatures exceeded threshold temperature.

The distribution developed from the analysis of current temperatures (0.32 to 0.46) is corroborated by the results of the regional survey (DTN: MO0010SPANYE00.001 [DIRS 154976]; DOE 1997 [DIRS 100332]), and information from Phoenix, Arizona. Residents of Amargosa Valley used evaporative coolers from 1 to 12 months a year (Figure 6-2), with an average of 5.9 months ( $49 \%$ of the year).

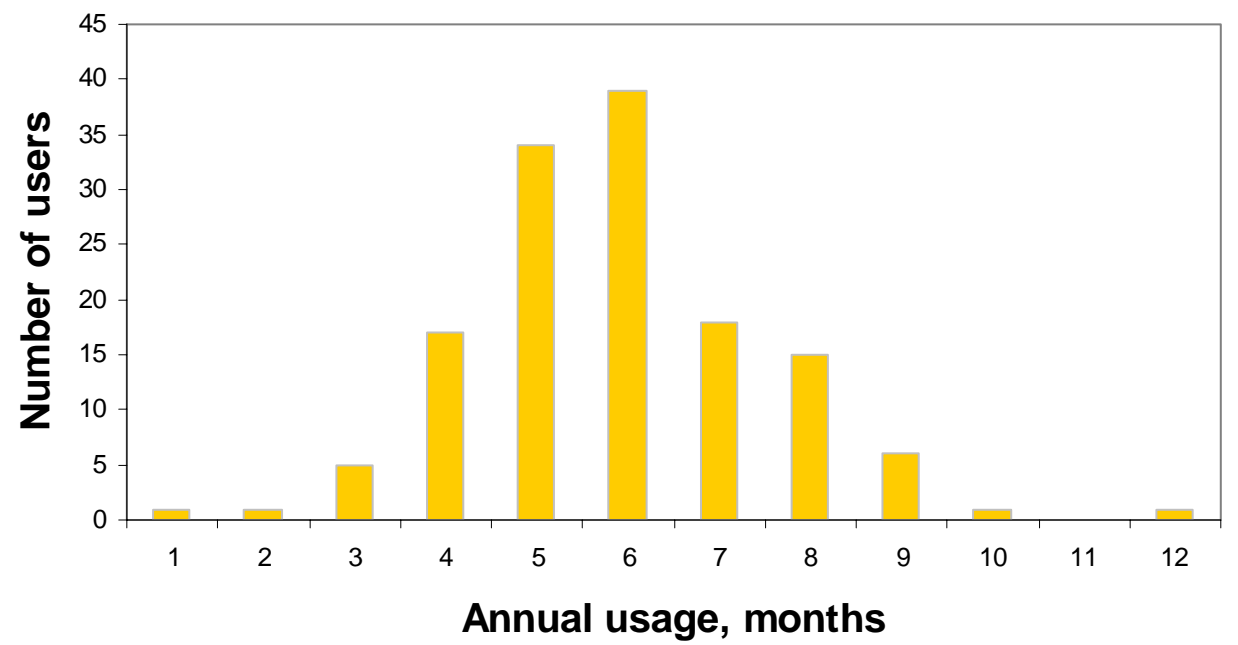

Source: DTN: MO0010SPANYE00.001 (DIRS 154976).

Figure 6-2. Evaporative Cooler Use in the Amargosa Valley

The average response to the survey question is about 10 percent higher than the average of the distribution based on daily maximum temperatures, and 3 percent higher than the maximum of that distribution (Table 6-18). It is expected that responses to the survey would result in a higher estimate of cooler use because the survey asked how many months per year an evaporative cooler was used. Coolers would be run for only a portion of the cooler months of early spring and late fall; therefore, an estimate based on days per year of operation should be lower than one based on months per year. Also, some survey respondents may have counted months during which they operated a cooler to ventilate their homes without running the water pump. 
Evaporative coolers were used for an average of 2,077 hours per year at about 40 houses in Phoenix, Arizona (Karpisak et al. 1998 [DIRS 160563], Table 1), which has comparable summer temperatures to southern Nevada. This is about 24 percent of the year (2077 hours / [365.25 days $x 24$ hours]). This is lower than the distribution of 0.32 to 0.46 because the evaporative cooler use factor is based on the proportion of days (versus hours) that coolers would be run.

\subsection{DIETARY CHARACTERISTICS OF THE RECEPTOR}

This section describes the development of the parameters related to the dietary characteristics of the RMEI. Distributions of consumption rates for locally produced foods were developed based on the food consumption survey (DTN: MO0010SPANYE00.001 [DIRS 154976]) and information on daily food intake in the western United States (USDA 2000 [DIRS 154158]).

Water consumption is defined at 10 CFR 63.312(d) [DIRS 156605], where it is stated that the RMEI drinks 2 liters of water per day $(2 \mathrm{~L} / \mathrm{d} \times 365.25 \mathrm{~d} / \mathrm{yr}=730.5 \mathrm{~L} / \mathrm{yr})$.

Another dietary attribute of the RMEI is the inadvertent soil ingestion rate. A rate of soil ingestion consistent with the region and lifestyle of the Amargosa Valley population was developed based on a literature review.

\subsubsection{Food Consumption Survey}

10 C.F.R. 63.312(b) establishes the requirements for determining the diet of the RMEI. The NRC directed DOE to "use projections based upon surveys of the people residing in the Town of Amargosa Valley, Nevada, to determine their current diets and living style" and to "use the mean values of these factors in the assessments" conducted to determine compliance with dose limits. These directions were followed as described below to assess the mean value of the current diets of Amargosa Valley's population.

Estimates of the amount of locally produced foods consumed by the RMEI are based upon a 1997 survey of the residents of Amargosa Valley (DOE 1997 [DIRS 100332]) (see Section 4.1.5). As part of that survey, people were asked how often they consumed foods locally produced in Amargosa Valley. A substantial portion of the people surveyed stated that they consumed little or no locally produced foods (Figures 6-4 to 6-12, see below for a description of how those figures were developed), and the range in frequency of consumption among respondents was large. For example, residents surveyed consumed locally produced foods from zero to over 300 days per year (Appendix C, file Consumption rates with uncertainties.xls). These results are to be expected for a population living in an area where there are few commercially produced foodstuffs and most locally produced foodstuffs come from seasonal gardens and personally owned livestock, because those foodstuffs would only be available to part of the population for part of the year.

To convert the consumption frequencies obtained from the survey into estimates of the amount of locally produced food consumed, as required in the ERMYN model to calculate ingestion exposure (BSC 2004 [DIRS 169460], Section 6.4.9), consumption frequencies were combined with estimates of daily intake of food by people in the western United States (see Section 6.4.2). Those estimates were obtained from the 1994-96 Continuing Survey of Food Intakes by 
Individuals conducted by the USDA (USDA 2000 [DIRS 154158]). As part of that survey, the daily food intake of about 16,000 people in the U.S. was measured, of which about 3,600 were from the western U.S. (USDA 2000 [DIRS 154158], Table 105). The estimates are appropriate for calculating the average daily consumption rates of the population of Amargosa Valley because they are based on a large sample of people and there is no reason to expect that the average amount of a food type consumed by those residents (on days when that food type is eaten) differs from the average of people in the western U.S.

Changes since 1997 in the agricultural industry in Amargosa Valley, the proportion of homes with gardens, and food preferences could affect estimates of the current diet the residents of Amargosa Valley. The sensitivity of the biosphere model to changes in availability of gardens and changes in food preferences are addressed in other biosphere reports (BSC 2004 [DIRS 170016]; changes in commercial agriculture are summarized here. During 1996 through 1999, from 1,798 to 2,072 acres were planted in Amargosa Valley during spring surveys, 91 to 93 percent of which was planted in alfalfa and other hay (CRWMS M\&O 1997 [DIRS 101090], Tables 3-12 and 3-13; YMP 1999 [DIRS 158212], Tables 10 and 11). In the spring of 2004, 2,392 acres of commercial fields identified in 1998 were revisited and most of the valley was surveyed for new agricultural fields. The 2,392 acres was about $85 \%$ of the total agricultural acreage in Amargosa Valley (including fallow fields) surveyed in 1998. About 1,978 acres surveyed in 2004 were planted in alfalfa and other hay (including 136 acres of previously uncultivated land), 45.3 acres had fruit or nut trees, 2.5 were to be planted, and 502.4 were fallow. In addition, 1,040 acres of previously non-cultivated land had been planted in pine tree seedlings (Rasmuson 2004 [DIRS 169506]). Thus, it is concluded that most agricultural fields in Amargosa Valley still are planted in crops that are not directly consumed by people. Other changes known to have occurred in the valley are that the commercial operation of the fish farm ceased after 1998 (Roe 2002 [DIRS 160674], p. 2) and a pistachio processing and packaging facility was opened some time after 2000 (based on personal observations of the authors of this analysis), which has increased the availability of locally produced nuts. Closure of the fish farm would not result in a substantial overestimate in the consumption rate of locally produced foods because few people surveyed consumed locally produced fish (Figure 12). Milk production at the Rockview Farms dairies in Amargosa Valley declined by about 2 percent and the average number of lactating cows per day decreased by around 9 percent (Rasmuson 2004 [DIRS 169506]). It is concluded that there have been no changes in the agricultural industry that would have resulted in substantial changes in the amount of locally produced food available to residents of Amargosa Valley.

Estimates of the amount of groundwater and locally produced foods consumed by residents of Amargosa Valley that were surveyed in 1997 are displayed in Figures 6-3 through 6-12. The food groups and methods used to calculate consumption rates are described in Section 6.4.2. The histograms were produced using the information in DTN MO0010SPANYE00.001 [DIRS 154976]. The estimates of groundwater consumption (Figure 6-3) are included for completeness and are not used to develop output for use in the biosphere model. Development of these histograms is documented in the Excel worksheet (Consumption rates with uncertainties.xls) included in Appendix C. The first bar in the figures depicts the number of respondents who did not consume a food type, the second bar corresponds to a consumption rate from greater than zero to the value under the second bar, the third bar corresponds to consumption rates from the value under the second bar to that under the third bar, and so on. 


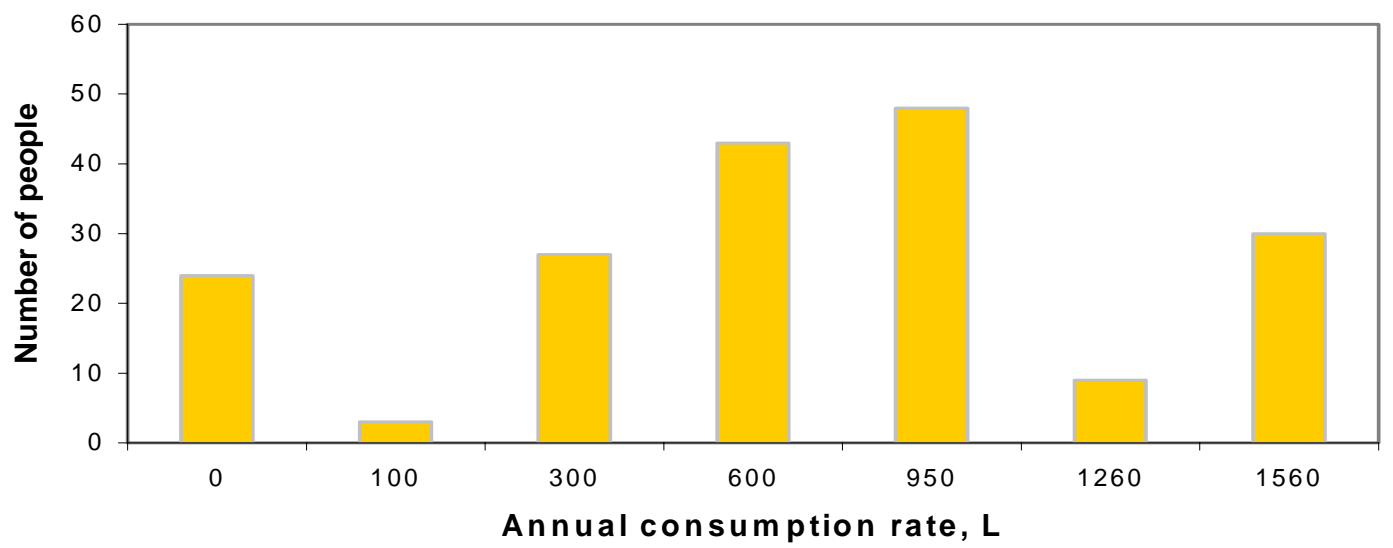

Source: DTN: MO0010SPANYE00.001 (DIRS 154976).

Figure 6-3. Annual Consumption Rates of Groundwater

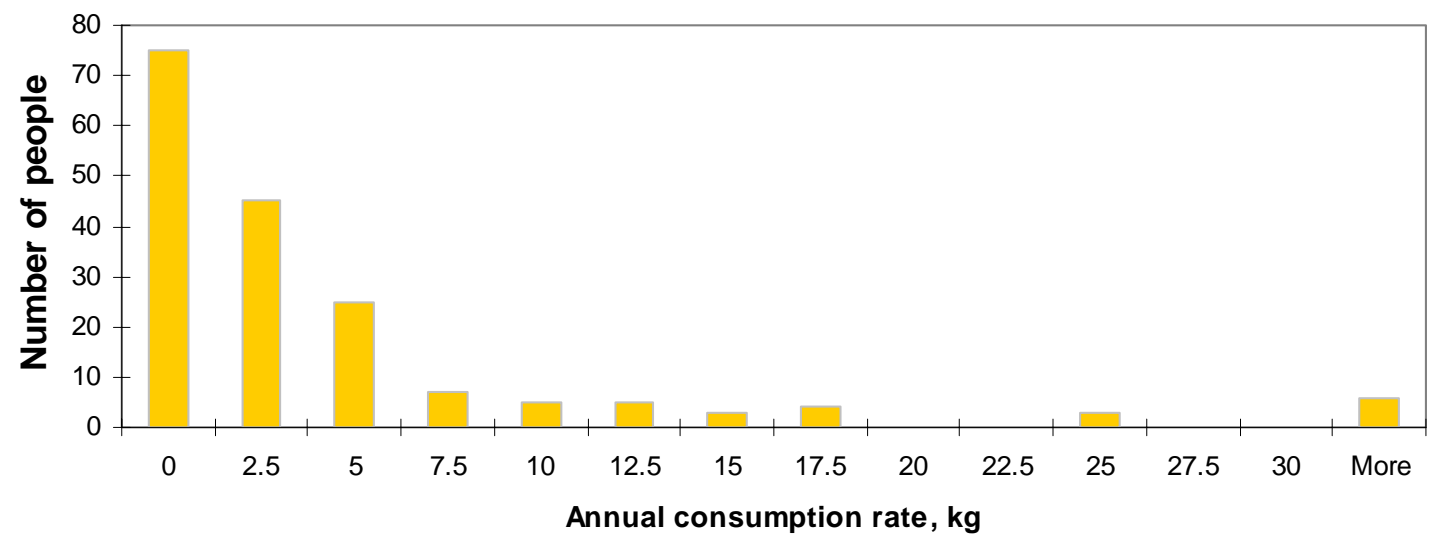

Source: DTN: MO0010SPANYE00.001 (DIRS 154976).

Figure 6-4. Annual Consumption Rates of Locally Produced Leafy Vegetables

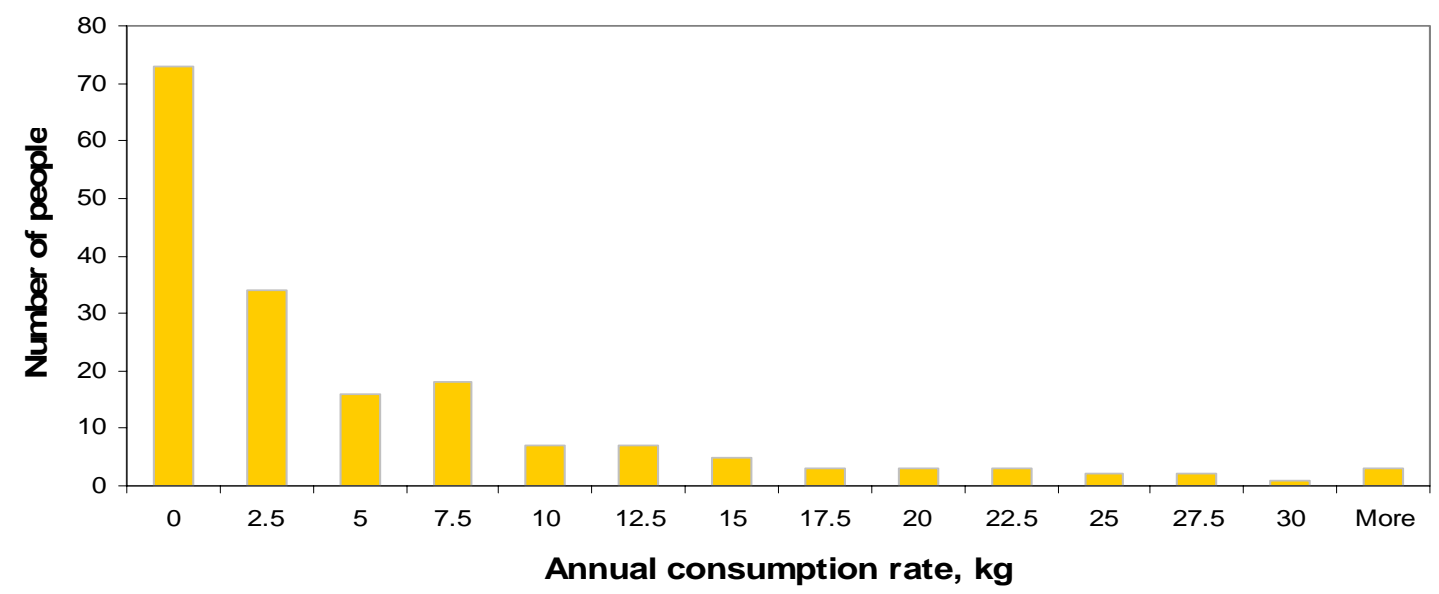

Source: DTN: MO0010SPANYE00.001 (DIRS 154976).

Figure 6-5. Annual Consumption Rates of Locally Produced Other Vegetables 


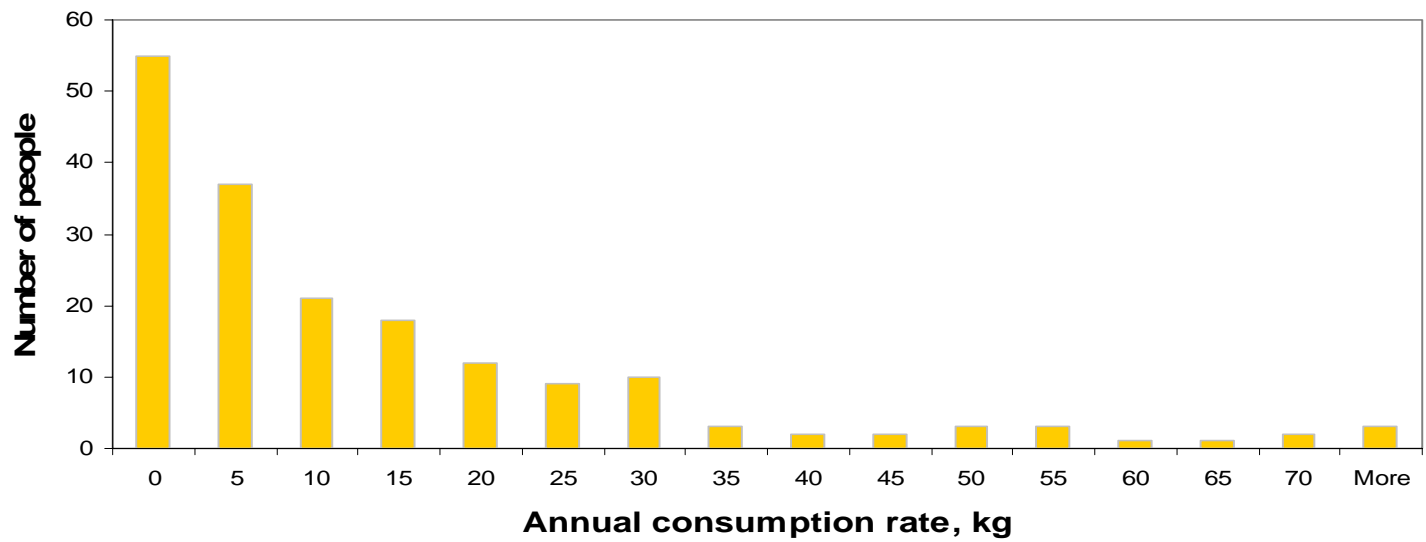

Source: DTN: MO0010SPANYE00.001 (DIRS 154976).

Locally produced fruit includes tomatoes.

Figure 6-6. Annual Consumption Rates of Locally Produced Fruit

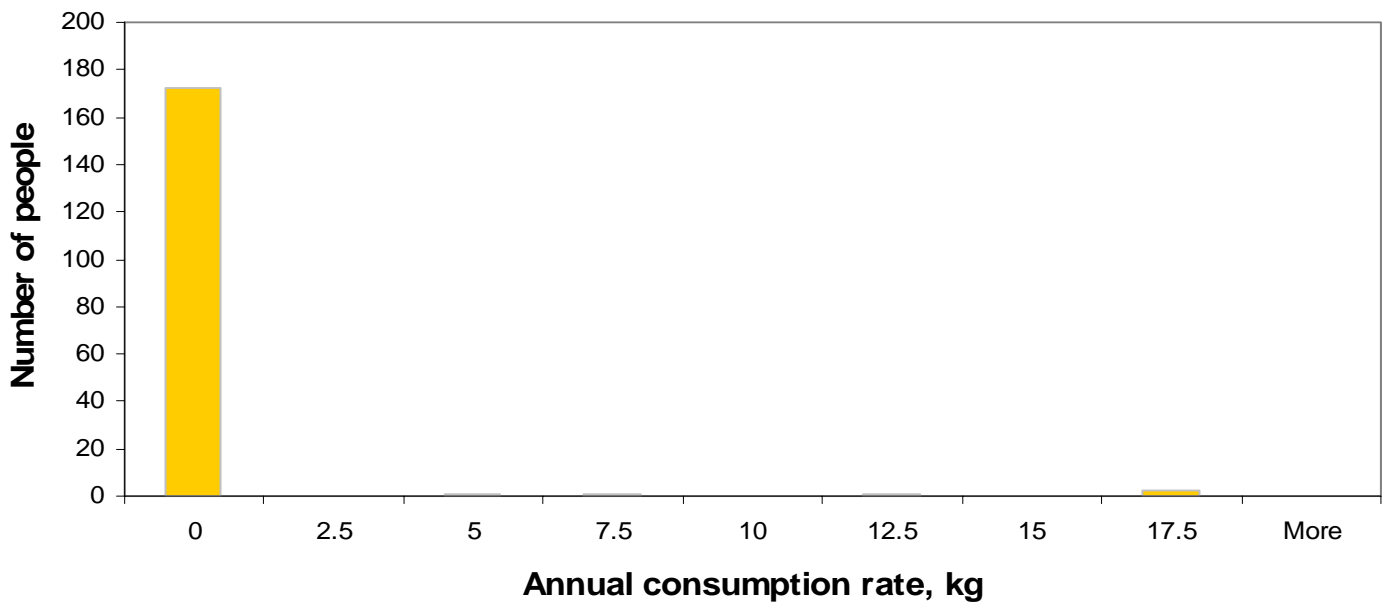

Source: DTN: MO0010SPANYE00.001 (DIRS 154976).

Figure 6-7. Annual Consumption Rates of Locally Produced Grain 


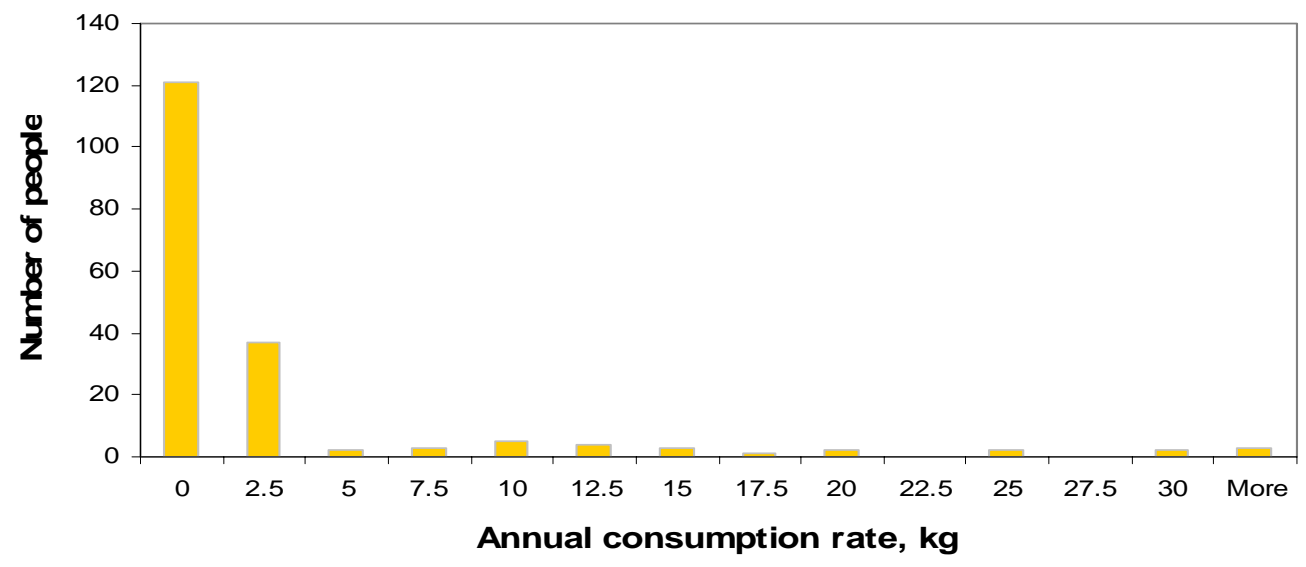

Source: DTN: MO0010SPANYE00.001 (DIRS 154976).

Figure 6-8. Annual Consumption Rates of Locally Produced Meat

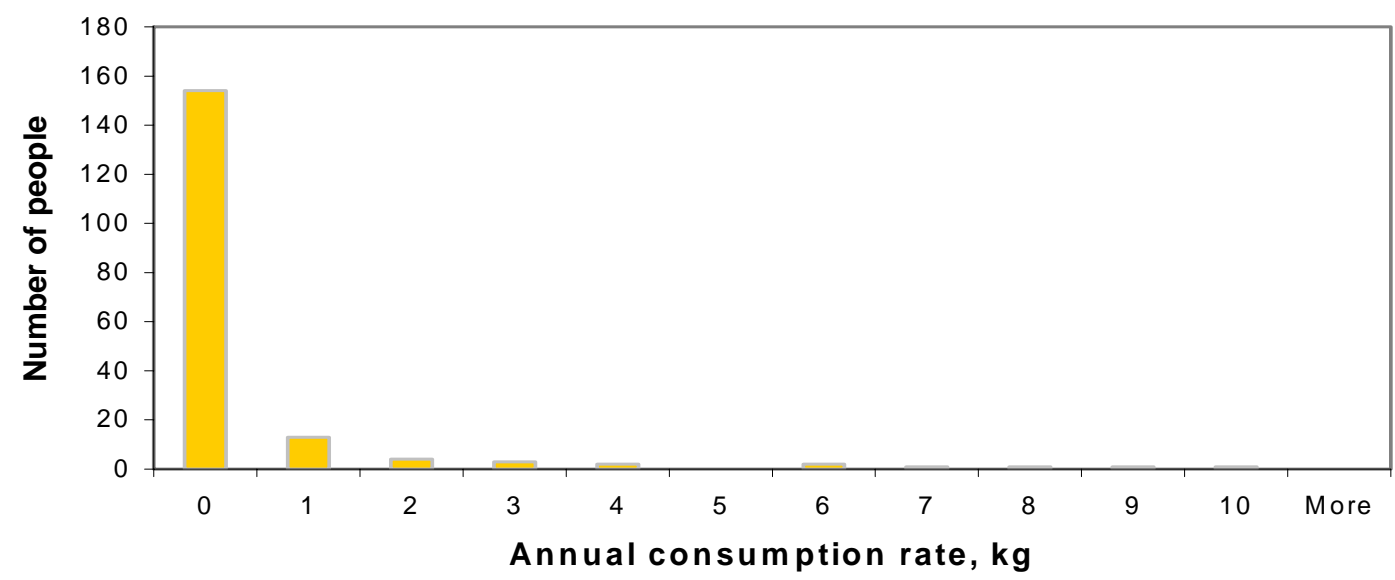

Source: DTN: MO0010SPANYE00.001 (DIRS 154976).

Figure 6-9. Annual Consumption Rates of Locally Produced Poultry

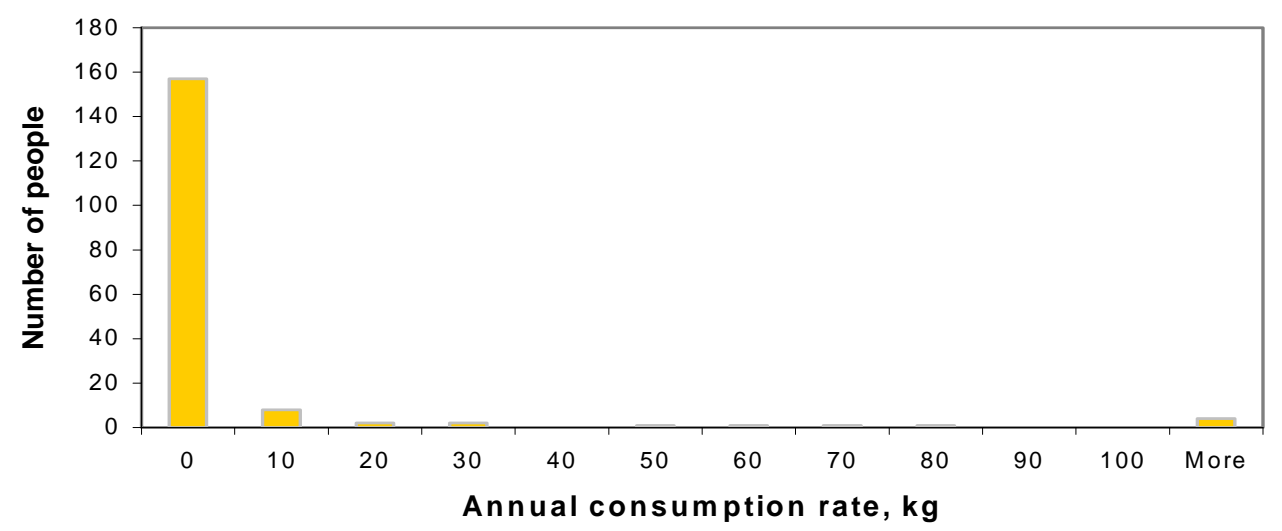

Source: DTN: MO0010SPANYE00.001 (DIRS 154976).

Figure 6-10. Annual Consumption Rates of Locally Produced Milk 


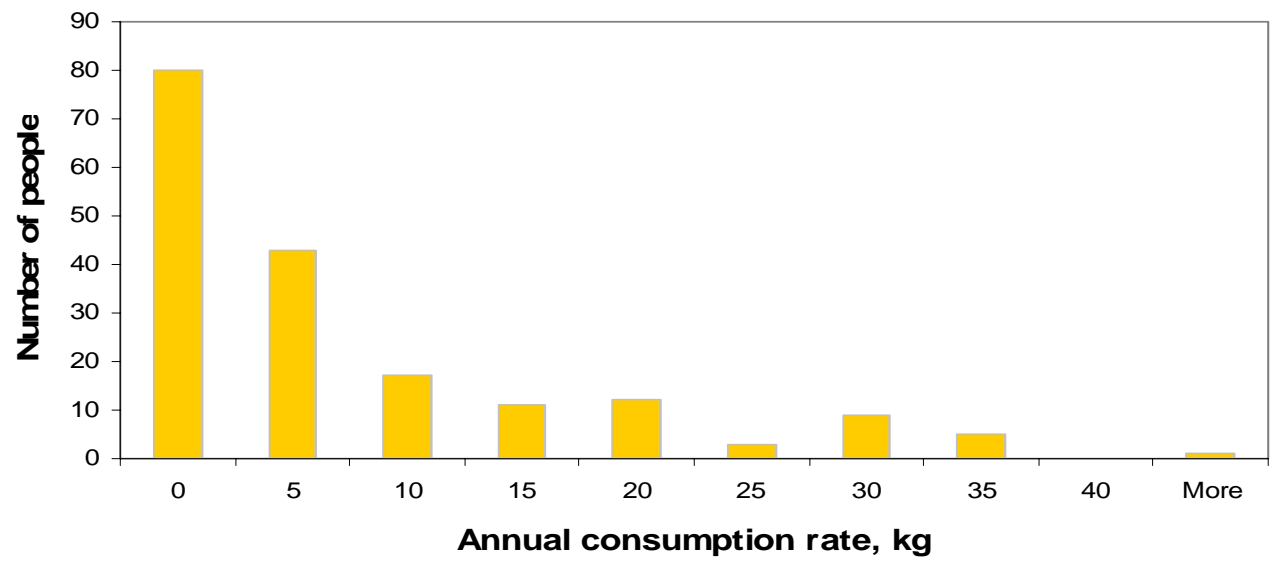

Source: DTN: MO0010SPANYE00.001 (DIRS 154976).

Figure 6-11. Annual Consumption Rates of Locally Produced Eggs

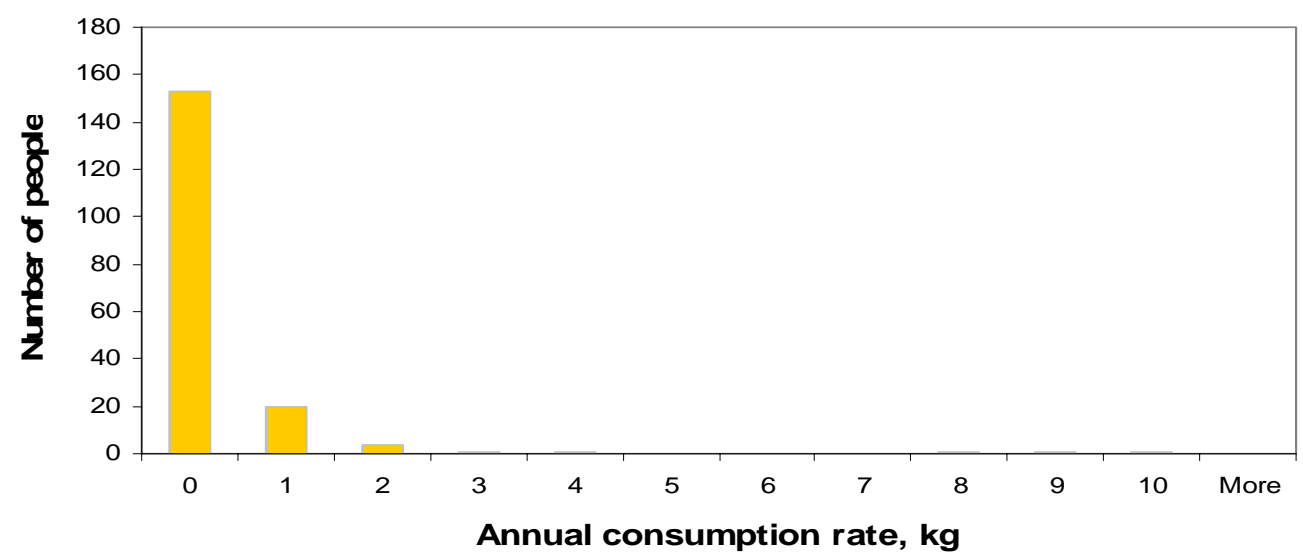

Source: DTN: MO0010SPANYE00.001 (DIRS 154976).

Figure 6-12. Annual Consumption Rates of Locally Produced Fish

\subsubsection{Calculation of Annual Consumption Rates of Locally Produced Food for the RMEI}

To include the consideration of uncertainty in the results of the food consumption survey, the annual consumption rates of locally produced food were recalculated from the frequency information and average daily food intake information. The frequency of consumption of locally produced food for the Amargosa Valley population was obtained from the 1997 survey of Amargosa Valley residents (DTN: MO0010SPANYE00.001 [DIRS 154976]). The average daily intake was obtained from the USDA 1994-96 Continuing Survey of Food Intakes by Individuals (USDA 2000 [DIRS 154158]). Table 6-20 contains the values of the average daily intakes, fraction of people consuming, and the respective standard error for the food groups included in the 1997 survey (BSC 2001 [DIRS 156016], p. 10).

The frequency of consumption can be calculated using the individual responses to the regional food consumption survey questions. The following description of the survey questions related to the food consumption is paraphrased from DOE (1997 [DIRS 100332], p. 30-31). For every food group, a series of four questions was asked. The first question asked if the respondent ate 
any locally produced food in a food group during the past year. Those who answered "yes" proceeded to the second, third and fourth questions. Those who answered "no" skipped to the next series of questions.

For a respondent who answered "yes" to the first question, the second question was how many months during the last year had some locally produced food in a food group been eaten. The response categories were 1-3 months, 4-6 months, 7-9 months, and 10-12 months. For calculating the food consumption rates, these responses were assigned the following values: 2,5 , 8, and 11 months, respectively (BSC 2001 [DIRS 156016], p. 16). The third question was how many days per week had locally produced food been eaten (for those months when that locally-produced food had been eaten): less than 1 day per week, 1-2 days per week, 3-4, 5-6, or 7 days per week. The corresponding values used in calculations were 0.5, 1.5, 3.5, 5.5, and 7 days per week, respectively (BSC 2001 [DIRS 156016], p. 16). The fourth question was how much of the total amount of food consumed was locally produced (for the months when locally-produced food had been eaten): all, most, some, or very little. These responses were assigned the following values: 100 percent, 75 percent, 50 percent, and 25 percent, respectively (BSC 2001 [DIRS 156016], p. 17).

Based on the responses to the survey questions and the value of the contingent average daily intake (CADI), annual food consumption rates were calculated as follows:

$$
U_{i, j}=M P Y_{i, j} \frac{365.25 d}{12 m o} D P W_{i, j} \frac{1 w k}{7 d} Q_{i, j} C A D I_{i}=E D P Y_{i, j} C A D I_{i}
$$

and

$$
E D P Y_{i, j}=M P Y_{i, j} \frac{365.25 d}{12 m o} D P W_{i, j} \frac{1 w k}{7 d} Q_{i, j}
$$

where

$$
\begin{array}{ll}
U_{i, j}= & \begin{array}{l}
\text { annual consumption of locally produced food from food group } i \text { by } \\
\text { individual } j(\mathrm{~kg} / \mathrm{yr})
\end{array} \\
M P Y_{i, j}= & \begin{array}{l}
\text { number of months per year that individual } j \text { consumed locally produced } \\
\text { food from group } i(\mathrm{mo} / \mathrm{yr})
\end{array} \\
D P W_{i, j}= & \begin{array}{l}
\text { number of days per week that individual } j \text { consumed locally produced food } \\
\text { from group } i(\mathrm{~d} / \mathrm{wk})
\end{array} \\
Q_{i, j}= & \begin{array}{l}
\text { locally produced fraction of total consumption during the months in which } \\
\text { respondent } j \text { consumed locally produced food from group } i \text { (dimensionless) }
\end{array} \\
C A D I_{i}= & \text { contingent average daily intake of food from group } i(\mathrm{~kg} / \mathrm{d}) \\
E D P Y_{i, j}= & \begin{array}{l}
\text { effective number of days per year that individual } j \text { consumed locally } \\
\text { produced food from group } i(\mathrm{~d} / \mathrm{yr})
\end{array}
\end{array}
$$

The CADI is the quantity that can be calculated from the average daily intake by dividing it by the fraction of people consuming food from a given food group on a day of the survey. The 
CADI is the average amount of food from each group that is consumed by individuals on the days that they consumed some food from that group, so it applies to the "doers".

Consumption rates presented in this report are based on a 365.25-day year to match the number of days per year used in the biosphere model. This approach is valid because the responses to survey questions concerning consumption of locally produced food do not depend on the number of days per year (see paragraphs above).

The last parameter in Equation 6.4-1, $E D P Y_{i, j}$, combines the results of the survey on consumption frequency of locally produced food for a given individual and a given food group. It is numerically equal to the number of days in a year at 100 percent consumption of locally produced food from a given food group by a given individual.

The average consumption rate of locally produced food is calculated as

$$
U_{i}=\overline{E D P Y}_{i, m} C A D I_{i, m} P M+\overline{E D P Y}_{i, f} C A D I_{i, f} P F
$$

where

$$
\begin{array}{ll}
U_{i} & =\begin{array}{l}
\text { annual average consumption of locally produced food from food group } i \\
\text { for Amargosa Valley adults }(\mathrm{kg} / \mathrm{yr})
\end{array} \\
\overline{E D P Y}_{i, m}= & \begin{array}{l}
\text { mean effective number of days per year that males from the Amargosa } \\
\text { Valley population consumed locally produced food from group } i(\mathrm{~d} / \mathrm{yr})
\end{array} \\
C A D I_{i, m}= & \begin{array}{l}
\text { contingent average daily intake of food from food group } i \text { for males } \\
(\mathrm{kg} / \mathrm{d})
\end{array} \\
P M & =\begin{array}{l}
\text { percent adult males in the Amargosa Valley population } \\
\text { mean effective number of days per year that females from the Amargosa }
\end{array} \\
C A D I_{i, f}= & \begin{array}{l}
\text { Valley population consumed locally produced food from group } i(\mathrm{~d} / \mathrm{yr}) \\
\text { contingent average daily intake of food from food group } i \text { for females }
\end{array} \\
& (\mathrm{kg} / \mathrm{d})
\end{array}
$$

The standard error in the value of $\mathrm{U}_{i}$ can be evaluated using the general formula for propagating errors (based on Bevington and Robinson 1992 [DIRS 147076], Section 3.2, Equation 3.14, and examples in Section 3.3) as

$$
\begin{aligned}
S E M_{U_{i}}{ }^{2} & =\left(\frac{\partial U_{i}}{\partial \overline{E D P Y}_{i, m}}\right)^{2}\left(S E M_{\overline{E D P Y}_{i, m}}\right)^{2}+\left(\frac{\partial U_{i}}{\partial C A D I_{i, m}}\right)\left(S E M_{\operatorname{CADI}_{i, m}}\right)^{2}+ \\
& +\left(\frac{\partial U_{i}}{\partial \overline{E D P Y}_{i, f}}\right)^{2}\left(S E M_{\overline{F_{\overline{E P Y} Y_{i, f}}}}\right)^{2}+\left(\frac{\partial U_{i}}{\partial C A D I_{i, f}}\right)^{2}\left(S E M_{C_{C A D I_{i, f}}}\right)^{2}
\end{aligned}
$$


where

$$
\begin{aligned}
& S E M_{\overline{E D P Y}_{i, m}}=\quad \begin{array}{l}
\text { Standard error of the mean effective number of days per year that } \\
\text { males from the Amargosa Valley population consumed locally } \\
\text { produced food from group } i(\mathrm{~d} / \mathrm{yr})
\end{array} \\
& S E M_{\mathrm{CADI}_{i, m}}=\begin{array}{l}
\text { Standard error of the mean CADI of food from food group } i \text { for males } \\
(\mathrm{kg} / \mathrm{d})
\end{array} \\
& S E M_{\overline{E D P Y}_{i, f}}=\begin{array}{l}
\text { Standard error of the mean effective number of days per year that } \\
\text { females from the Amargosa Valley population consumed locally }
\end{array} \\
& S E M_{\text {fADI }_{i, f}=} \begin{array}{l}
\text { produced food from group } i(\mathrm{~d} / \mathrm{yr}) \\
\text { Standard error of the mean CADI of food from food group } i \text { for } \\
\text { females }(\mathrm{kg} / \mathrm{d})
\end{array}
\end{aligned}
$$

Using the expression for $U_{i}$ (Equation 6.4-2), the standard error of the mean consumption rate of food from group $i$ is calculated as

$$
\begin{aligned}
S E M_{U_{i}}{ }^{2}= & \left(\left(C A D I_{i, m}\right)^{2}\left(S E M_{\overline{E D P Y}_{i, m}}\right)^{2}+\left(\overline{E D P Y}_{i, m}\right)^{2}\left(S E M_{C_{C A D I_{i, m}}}\right)^{2}\right)(P M)^{2}+ \\
& \left(\left(C A D I_{i, f}\right)^{2}\left(S E M_{\overline{E D P Y}_{i, f}}\right)^{2}+\left(\overline{E D P Y}_{i, f}\right)^{2}\left(S E M_{\left.\left.C_{C A D I_{i, f}}\right)^{2}\right)(P F)^{2}}\right.\right.
\end{aligned}
$$

As noted above, the value of CADI is defined as the average amount of food from a given food group that is consumed during a one-day period by all individuals who consumed that food. In other words, the people who did not consume that food are not included in calculation of the CADI. The CADI (BSC 2001 [DIRS 156016], p. 7) is computed as

$$
C A D I_{i}=\frac{A D I_{i}}{F P C_{i}}
$$

where

$$
\begin{aligned}
C A D I_{i}= & \text { contingent average daily intake of food group } i(\mathrm{~kg} / \mathrm{d}) \\
A D I_{i}= & \text { average daily intake of food group } i(\mathrm{~kg} / \mathrm{d}) \\
F P C_{i}= & \text { fraction of people consuming food from food group } i \text { per day } \\
& \text { (dimensionless) }
\end{aligned}
$$

The standard error of the CADI values can be calculated using the formula for error propagation (based on Bevington and Robinson 1992 [DIRS 147076], Equation 3.14 in Section 3.2 and examples in Section 3.3) as 


$$
\begin{aligned}
S_{S E M_{C_{A D I_{i}}}^{2}}=\left(\frac{\partial C A D I_{i}}{\partial A D I_{i}}\right)^{2}\left(S E M_{A D I_{i}}\right)^{2}+\left(\frac{\partial C A D I_{i}}{\partial F P C_{i}}\right)^{2}\left(S_{F P C_{i}}\right)^{2}= \\
=\left(\frac{1}{F P C_{i}}\right)^{2}\left(S E M_{A D I_{i}}\right)^{2}+\left(-\frac{A D I_{i}}{\left(F P C_{i}\right)^{2}}\right)^{2}\left(S E M_{F P C_{i}}\right)^{2}= \\
=\left(\frac{S E M_{A D I_{i}}}{F P C_{i}}\right)^{2}+\left(\frac{A D I_{i} S E M_{F P C_{i}}}{\left(F P C_{i}\right)^{2}}\right)^{2} \\
S E M_{C_{C A D I_{i}}}=\sqrt{\left(\frac{S E M_{A D I_{i}}}{F P C_{i}}\right)^{2}+\left(\frac{A D I_{i} S E M_{F P C_{i}}}{\left(F P C_{i}\right)^{2}}\right)^{2}}
\end{aligned}
$$

where

$$
\begin{aligned}
& S E M_{C A D I_{i}} \quad=\text { Standard error of the mean CADI for food type } i \\
& S E M_{A D I_{i}} \quad=\text { Standard error of the mean average daily intake, } A D I \text {, for food type } i \\
& S E M_{F P C_{i}} \quad=\text { Standard error of the mean fraction of people consuming, FPC, for }
\end{aligned}
$$

The standard errors of the CADIs calculated using Equation 6.4-6 are shown in Table 6-20.

The effective number of days per year that individual members of the Amargosa Valley population consumed locally produced food from group $i(\mathrm{~d} / \mathrm{yr})$ were calculated from the survey data using equation 6.4-1. The mean values, separately for the males and females, as well as the standard deviations, count, and standard errors of the means were calculated in an Excel spreadsheet (Appendix A). The Excel file, Consumption rates with uncertainties.xls, is included in Appendix C. The summary of the statistics is provided in Table 6-21.

The mean consumption rates of locally produced food for both genders for the survey food groups were then calculated using Equation 6.4-2 and the standard error of the means were calculated using Equation 6.4-4. These calculations are summarized in Appendix A and the results are summarized in Table 6-21.

The values of percent population ( $P M$ and $P F$ in Equations 6.4-2 and 6.4-4) were based on the 2000 Census data (Bureau of the Census 2002 [DIRS 159728], Table P8) rather than the food consumption survey data to correctly represent the proportions of genders for the current population (women were over-represented in the regional survey (DOE 1997 [DIRS 100332], Section 3.5 and Table 3.5.2)). The 2000 Census data indicated that there were fewer women then men among the population of the Amargosa Valley. 
The food types used in the biosphere model are not exactly the same as the food groups used in the regional survey. For the biosphere model some of the regional survey food groups were combined as shown below.

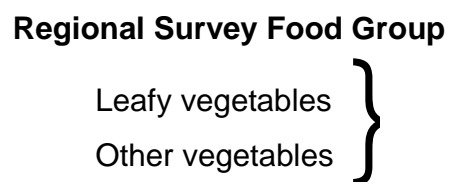

Fruit

Tomatoes

Grain

Beef

Pork

Wild Game

Poultry

Milk

Eggs

Fish

\section{Biosphere Model Food Type}

Leafy vegetables

Other vegetables

Fruit

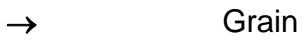

$\rightarrow \quad$ Meat

$\rightarrow \quad$ Poultry

$\rightarrow \quad$ Milk

$\rightarrow \quad$ Eggs

$\rightarrow \quad$ Fish

The mean consumption rates for meat and fruit, which are composed of more than one food group used in the regional survey, were calculated by adding the mean consumption rates for the regional survey food groups. The calculation of the standard errors of the means was performed by taking the square root of the sum of squares of standard errors of the consumption rates for the regional survey (Appendix A). The results are also shown in Table 6-21.

The analysis provided above uses data generated from local and national surveys and develops the expected (i.e., mean) value of annual consumption of each food type for the Amargosa Valley population. Being based upon sampling processes, the results are subject to statistical errors that have been quantified in terms of the standard error of the value developed (i.e., the expected standard deviation of the estimated mean).

The biosphere model can accept stochastic input to propagate the effects of parametric variability and uncertainty (BSC 2004 [DIRS 169460], Section 6), and the question arises as to what approach to use to estimate the variability of each parameter around the calculated mean value. One approach would be to use the Student- $t$ test for confidence testing (Bulmer 1979 [DIRS 111961], p. 148) and establish a predetermined confidence limit (such as the 95 percent) into which the true mean should fall. It could then be stated that, to the predetermined confidence level, the true mean lies over this range with uniform probability. However, for several parameters where the standard error has a value similar to the calculated mean, this approach would lead to a sampled value corresponding to negative food consumption rates. If this condition were to be remedied by simple truncation at zero consumption, there would be a systematic bias in the mean value of the sampled parameter. 
Table 6-20. Annual Daily Intake and Fraction of People Consuming for Respondents in the Western Region and the Calculated Contingent Annual Daily Consumption by Food Type

\begin{tabular}{|c|c|c|c|c|c|c|c|c|}
\hline \multirow{2}{*}{$\begin{array}{c}1997 \text { Food } \\
\text { Consumption } \\
\text { Survey Food } \\
\text { Group }\end{array}$} & \multirow[b]{2}{*}{$\begin{array}{l}\text { 94-96 USDA } \\
\text { Food Group }^{\text {a }}\end{array}$} & \multirow[b]{2}{*}{ Gender } & \multicolumn{2}{|c|}{$\begin{array}{c}\text { Average Daily Intake } \\
(\mathrm{g})^{\mathrm{b}}\end{array}$} & \multicolumn{2}{|c|}{$\begin{array}{l}\text { Fraction of People Consuming } \\
\text { (dimensionless) }\end{array}$} & \multicolumn{2}{|c|}{$\begin{array}{c}\text { Contingent Average Daily Intake } \\
(\mathrm{g})^{\mathrm{c}}\end{array}$} \\
\hline & & & AM & SE & AM & SE & AM & SE \\
\hline \multirow{2}{*}{$\begin{array}{l}\text { Leafy } \\
\text { Vegetables }\end{array}$} & \multirow{2}{*}{$\begin{array}{l}\text { Dark-green } \\
\text { vegetables }\end{array}$} & M & 13 & 3 & 0.103 & 0.015 & 126.2 & 34.4 \\
\hline & & $\mathrm{F}$ & 16 & 3 & 0.133 & 0.014 & 120.3 & 25.9 \\
\hline \multirow{2}{*}{$\begin{array}{l}\text { Other } \\
\text { vegetables }\end{array}$} & \multirow{2}{*}{ White potatoes } & M & 66 & 6 & 0.417 & 0.021 & 158.3 & 16.4 \\
\hline & & $\mathrm{F}$ & 43 & 3 & 0.350 & 0.016 & 122.9 & 10.2 \\
\hline \multirow{2}{*}{ Fruit } & \multirow{2}{*}{ Total fruits } & M & 194 & 12 & 0.535 & 0.022 & 362.6 & 26.9 \\
\hline & & $\mathrm{F}$ & 181 & 15 & 0.603 & 0.025 & 300.2 & 27.8 \\
\hline \multirow{2}{*}{ Tomatoes } & \multirow{2}{*}{ Tomatoes } & M & 43 & 2 & 0.447 & 0.010 & 96.2 & 5.0 \\
\hline & & $\mathrm{F}$ & 27 & 2 & 0.398 & 0.022 & 67.8 & 6.3 \\
\hline \multirow{2}{*}{ Grain } & \multirow{2}{*}{$\begin{array}{l}\text { Total grain } \\
\text { products }\end{array}$} & M & 382 & 18 & 0.973 & 0.007 & 392.6 & 18.7 \\
\hline & & $\mathrm{F}$ & 266 & 12 & 0.968 & 0.005 & 274.8 & 12.5 \\
\hline \multirow{2}{*}{ Beef } & \multirow{2}{*}{ Beef } & M & 37 & 3 & 0.258 & 0.024 & 143.4 & 17.7 \\
\hline & & $\mathrm{F}$ & 17 & 2 & 0.194 & 0.014 & 87.6 & 12.1 \\
\hline \multirow{2}{*}{ Pork } & \multirow{2}{*}{ Pork } & $M$ & 12 & 2 & 0.169 & 0.012 & 71.0 & 12.9 \\
\hline & & $\mathrm{F}$ & 6 & 1 & 0.132 & 0.014 & 45.5 & 9.0 \\
\hline \multirow{2}{*}{ Wild Game } & \multirow{2}{*}{$\begin{array}{l}\text { Lamb, Veal, } \\
\text { Game }\end{array}$} & $\mathrm{M}$ & 2 & 1 & 0.012 & 0.007 & 166.7 & 128.0 \\
\hline & & $\mathrm{F}$ & 1 & 1 & 0.010 & 0.004 & 100.0 & 107.7 \\
\hline \multirow{2}{*}{ Poultry } & \multirow{2}{*}{ Total poultry } & $M$ & 29 & 3 & 0.215 & 0.012 & 134.9 & 15.9 \\
\hline & & $\mathrm{F}$ & 17 & 2 & 0.207 & 0.018 & 82.1 & 12.0 \\
\hline \multirow{2}{*}{ Milk } & \multirow{2}{*}{ Total fluid milk } & $\mathrm{M}$ & 193 & 9 & 0.496 & 0.020 & 389.1 & 24.0 \\
\hline & & $\mathrm{F}$ & 155 & 10 & 0.513 & 0.025 & 302.1 & 24.4 \\
\hline \multirow{2}{*}{ Eggs } & \multirow{2}{*}{ Eggs } & $M$ & 29 & 3 & 0.239 & 0.019 & 121.3 & 15.8 \\
\hline & & $\mathrm{F}$ & 18 & 2 & 0.189 & 0.012 & 95.2 & 12.2 \\
\hline \multirow{2}{*}{ Fish } & \multirow{2}{*}{$\begin{array}{l}\text { Fish and } \\
\text { shellfish }\end{array}$} & M & 12 & 2 & 0.093 & 0.009 & 129.0 & 24.9 \\
\hline & & $\mathrm{F}$ & 9 & 2 & 0.078 & 0.012 & 115.4 & 31.2 \\
\hline
\end{tabular}

${ }^{a}$ The food groups were selected such that the resulting CADI is the most conservative (BSC 2001 [DIRS 156016], pp. 8-10).

${ }^{b}$ USDA 2000 [DIRS 154158], Tables 86A to 91A and 86Ase to 91Ase (average daily intake), 86B to 91B and 86Bse to 91Bse (fraction of people consuming).

'Calculated using equations 6.4-5 and 6.4-6 in spreadsheet "Consumption rates" of the Excel file Consumption rates with uncertainties.xls (Appendix C)", as explained in Appendix A.

$\mathrm{AM}=$ arithmetic mean, $\mathrm{SE}=$ standard error. 
Table 6-21. Effective Number of Days for Consumption of Locally Produced Food and Annual Consumption Rates by Survey Food Group and by Biosphere Model Food Type

\begin{tabular}{|c|c|c|c|c|c|c|c|c|c|c|c|}
\hline \multirow{3}{*}{$\begin{array}{c}1997 \text { Food } \\
\text { Consumption } \\
\text { Survey Food } \\
\text { Group }\end{array}$} & \multirow[b]{3}{*}{ Gender } & \multirow{2}{*}{\multicolumn{5}{|c|}{$\begin{array}{l}\text { Effective Number of Days per Year When Locally Produced } \\
\text { Food is Consumed (d/yr) a }\end{array}$}} & \multicolumn{4}{|c|}{ Annual Consumption Rate (kg/yr) } & \multirow{3}{*}{$\begin{array}{c}\text { Biosphere } \\
\text { Model Food } \\
\text { Types }\end{array}$} \\
\hline & & & & & & & \multicolumn{2}{|c|}{ Survey Food Groups } & \multicolumn{2}{|c|}{$\begin{array}{l}\text { Biosphere Model } \\
\text { Food Types }\end{array}$} & \\
\hline & & AM & ASD & Count & SE & \% Popul. ${ }^{\text {b }}$ & $A M^{c}$ & SE $^{\mathrm{d}}$ & AM & SE & \\
\hline \multirow{2}{*}{$\begin{array}{l}\text { Leafy } \\
\text { vegetables }\end{array}$} & $\mathrm{M}$ & 30.70 & 60.15 & 70 & 7.19 & 0.522 & \multirow{2}{*}{3.78} & \multirow{2}{*}{0.88} & \multirow{2}{*}{3.78} & \multirow{2}{*}{0.88} & \multirow{2}{*}{$\begin{array}{l}\text { Leafy } \\
\text { vegetables }\end{array}$} \\
\hline & $\mathrm{F}$ & 30.53 & 60.36 & 108 & 5.81 & 0.478 & & & & & \\
\hline \multirow{2}{*}{$\begin{array}{l}\text { Other } \\
\text { vegetables }\end{array}$} & $\mathrm{M}$ & 30.76 & 49.61 & 70 & 5.93 & 0.522 & \multirow{2}{*}{4.73} & \multirow{2}{*}{0.67} & \multirow{2}{*}{4.73} & \multirow{2}{*}{0.67} & \multirow{2}{*}{$\begin{array}{l}\text { Other } \\
\text { vegetables }\end{array}$} \\
\hline & $\mathrm{F}$ & 37.22 & 58.67 & 107 & 5.67 & 0.478 & & & & & \\
\hline \multirow{2}{*}{ Fruit } & $\mathrm{M}$ & 22.16 & 38.03 & 70 & 4.55 & 0.522 & \multirow{2}{*}{9.35} & \multirow{2}{*}{1.28} & \multirow{4}{*}{$12.68^{\mathrm{e}}$} & \multirow{4}{*}{$1.36^{f}$} & \multirow{4}{*}{ Fruit } \\
\hline & $\mathrm{F}$ & 35.91 & 55.12 & 111 & 5.23 & 0.478 & & & & & \\
\hline \multirow{2}{*}{ Tomatoes } & $\mathrm{M}$ & 33.25 & 47.35 & 53 & 6.50 & 0.522 & \multirow{2}{*}{3.33} & \multirow{2}{*}{0.48} & & & \\
\hline & $\mathrm{F}$ & 51.17 & 89.31 & 87 & 9.58 & 0.478 & & & & & \\
\hline \multirow{2}{*}{ Grain } & $\mathrm{M}$ & 0.00 & 0.00 & 71 & 0.00 & 0.522 & \multirow{2}{*}{0.23} & & & & Grain \\
\hline & $\mathrm{F}$ & 1.76 & 8.85 & 106 & 0.86 & 0.478 & & 0.11 & 0.23 & 0.11 & Graın \\
\hline & $\mathrm{M}$ & 19.34 & 61.11 & 71 & 7.25 & 0.522 & & & & & \\
\hline Beef & $\mathrm{F}$ & 17.59 & 54.34 & 109 & 5.20 & 0.478 & 2.18 & 0.62 & & & \\
\hline Pork & $M$ & 7.63 & 31.11 & 71 & 3.69 & 0.522 & 053 & 017 & $285^{\mathrm{g}}$ & $065^{f}$ & Meat \\
\hline PUIK & $\mathrm{F}$ & 11.59 & 37.30 & 112 & 3.52 & 0.478 & 0.53 & 0.17 & $2.80^{\circ}$ & & Ivieal \\
\hline Wild game & $\mathrm{M}$ & 0.72 & 3.33 & 71 & 0.40 & 0.522 & 013 & 010 & & & \\
\hline vvilu game & $\mathrm{F}$ & 1.50 & 7.76 & 112 & 0.73 & 0.478 & & 0.10 & & & \\
\hline & $\mathrm{M}$ & 4.31 & 13.89 & 70 & 1.66 & 0.522 & & 013 & 042 & 013 & Poultry \\
\hline Poultry & $\mathrm{F}$ & 2.90 & 11.28 & 112 & 1.07 & 0.478 & 0.42 & 0.13 & 0.42 & 0.13 & Poultry \\
\hline Milk & $M$ & 13.03 & 59.93 & 69 & 7.21 & 0.522 & 466 & 168 & 466 & 168 & Milk \\
\hline IVIIIK & $\mathrm{F}$ & 13.97 & 56.27 & 108 & 5.41 & 0.478 & 4.06 & 1.08 & 4.60 & 1.08 & IVIIIK \\
\hline Fags & $\mathrm{M}$ & 34.82 & 69.48 & 70 & 8.30 & 0.522 & 530 & 083 & 530 & 083 & Fags \\
\hline cygs & $\mathrm{F}$ & 67.86 & 94.66 & 111 & 8.98 & 0.478 & 0.00 & 0.00 & 0.50 & 0.00 & cygs \\
\hline Fish & $\mathrm{M}$ & 1.72 & 8.87 & 70 & 1.06 & 0.522 & 023 & 010 & 023 & 010 & Fich \\
\hline FISII & $\mathrm{F}$ & 2.13 & 9.81 & 112 & 0.93 & 0.478 & $0 . \angle 0$ & 0.10 & $0 . \angle 0$ & 0.10 & FISII \\
\hline
\end{tabular}

${ }^{a}$ Calculated in Excel spreadsheet from the consumption frequency data (DTN: MO0010SPANYE00.001 [DIRS 154976]) as described in Appendix A.

${ }^{b}$ Calculated based on Bureau of the Census (2002 [DIRS 159728], Table P8). Concerns adult population, i.e., more than 17 years old.

${ }^{c}$ Calculated using equation 6.4-2.

${ }^{\mathrm{d}}$ Calculated using equation 6.4-4.

e Calculated as a sum of consumption rates for fruit and tomatoes.

${ }^{f}$ Calculated by taking the square root of the sum of squares of the SEs of the consumption rates for the regional survey food groups.

${ }^{g}$ Calculated as a sum of consumption rates for beef, pork, and game. The combined value was calculated in the spreadsheet. Therefore, it differs by $0.01 \mathrm{~kg} / \mathrm{yr}$ from the sum of components presented in the table.

$\mathrm{AM}=$ arithmetic mean; $\mathrm{ASD}=$ arithmetic standard deviation; SE=standard error 
A more realistic approach can be developed. The calculation of the mean value of a given consumption parameter involves taking the product of several factors, each of which is subject to uncertainty (Equations 6.4-1 and 6.4-2). By considering the logarithm of the parameter, the mathematical operation of taking the product of a number of factors is transformed to taking the sum of the logarithms of each of the factors. Based on the central limit theorem (Bulmer 1979 [DIRS 111961], p. 115), the distribution of the logarithm of that parameter will be approximately normal. Thus, a reasonable approximating distribution for the actual parameter is a lognormal distribution. A lognormal distribution possesses the beneficial attribute that it is limited to positive parameter values. The use of this distribution eliminates the artificial condition of negative food consumption as discussed above or as would arise by using the normal distribution.

In the analysis to generate the consumption rates, the available data are only sufficient to calculate the first and second moments (the mean and the standard deviation). Any distribution used to approximate the variability of the derived parameters should only require the definition of two parameters to uniquely specify the proposed distribution. The lognormal distribution meets this requirement.

\subsubsection{Inadvertent Soil Ingestion}

Soil contains the largest inventory of radioactivity of all components of the biosphere system for both exposure scenarios. For the volcanic ash scenario, this is because the soil or the mixture of soil and ash is the source of contamination, and for the groundwater scenario, the soil receives the majority of the contamination from irrigation water. Direct intake of soil was included in the biosphere model. Contamination of surface soil occurs during crop irrigation with contaminated water or during deposition of contaminated volcanic ash on the soil surface. For the groundwater exposure scenario, it is assumed that irrigation continues sufficiently long for the buildup of radionuclides and their decay products in soil to occur and for radionuclide concentrations to reach equilibrium (BSC 2004 [DIRS 169460], Section 5) .

Ingestion of soil by humans can be divided into two distinct phenomena: inadvertent and deliberate (geophagia). Deliberate soil ingestion is frequently referred to as soil pica (pica being defined as an eating disorder manifested by a craving to ingest any material unsuitable for food); thus geophagia is a special case of pica. Inadvertent ingestion of soil may be a result of swallowing dirt or dust accompanying mouth breathing, via food items contaminated with soil, as well as from mouthing of dirty hands or other contaminated non-food items, such as cigarettes (Simon 1998 [DIRS 160098], p. 648). Increased soil ingestion may be related to the living conditions or professions that bring people into close and continual contact with the soil (Simon 1998 [DIRS 160098], p. 647). Deliberate soil ingestion is considered to be relatively uncommon (EPA 1997 [DIRS 103038], p. 4-1).

Purposeful ingestion of soil (i.e., geophagia) is not considered in the development of this parameter. Geophagia is a disorder characterized by purposeful eating of soil. This disorder is uncommon and is usually confined to infants and children (EPA 1997 [DIRS 103038], Section 4.5). To comply with 10 CFR 63.312, which states that projections of diet must be based on the average of the adults in the Amargosa Valley, geophagia is not considered in the estimate of soil ingestion. 
Soil ingestion rates for the biosphere model were developed based on inadvertent average daily intake of soil reported in the literature. The studies of soil ingestion among adults are limited in number compared with studies of pica in children (EPA 1997 [DIRS 103038], p. 4-1), and only a few studies involving the direct measurements of adult soil ingestion rates have been conducted. In most publications on the subject of inadvertent soil ingestion by adults, the ingestion rates are estimated partly based on existing measurements and partly on assumptions. Soil ingestion by humans was the subject of a comprehensive review by Simon (1998 [DIRS 160098], p. 647-672), which included applications of soil ingestion rate to risk assessment of radioactively contaminated soil. That review includes an evaluation of existing data and their sources as well as recommendations regarding soil ingestion values for different environments, populations, and exposure scenarios.

A summary of the information on inadvertent soil ingestion rates for adults is given in Table 6-22, which lists the literature sources and the associated values, ranges, and distributions, where applicable.

The measured and assessed values of inadvertent soil ingestion rates are in the range of less than $1 \mathrm{mg} / \mathrm{d}$ for clean indoor environments to several hundred $\mathrm{mg} / \mathrm{d}$ for dusty outdoor environments (Table 6-22). Most of the dose and risk assessment models use $100 \mathrm{mg} / \mathrm{d}$ as the default value for the rate of inadvertent soil ingestion (Table 6-22). The value of $100 \mathrm{mg} / \mathrm{d}$ is also recommended by the EPA for residential and agricultural scenarios (EPA 1997 [DIRS 103038], p. 4-21). Although the most recent measurements indicate that the soil ingestion rates are about an order of magnitude lower than this value (Stanek et al. 1997 [DIRS 160251], p. 249), consideration was given to site-specific conditions. The nature of the Amargosa Valley environment, especially the frequent wind, sparse vegetation, and arid climate, suggests that the average value of inadvertent soil ingestion rate of $100 \mathrm{mg} / \mathrm{d}$ recommended by the EPA for agricultural scenarios is appropriate for the use in the biosphere model.

The uncertainty distributions recommended by Simon (1998 [DIRS 160098], p. 663) for the inadvertent soil ingestion rate are lognormal with the geometric standard deviation of 3.2. Because the RMEI represents the average adult in the Amargosa Valley population, the uncertainty distribution for the rate of inadvertent soil ingestion should be associated with the uncertainty of the mean rather than with the population variability. The geometric means of the uncertainty distributions recommended by Simon (1998 [DIRS 160098], p. 663) for the inadvertent soil ingestion rate for various agricultural scenarios and rural lifestyles range from 50 to $200 \mathrm{mg} / \mathrm{d}$. Therefore, it is recommended that the inadvertent soil ingestion for the RMEI be represented by a piece-wise cumulative distribution with the following characteristics: (50 mg/d, 0 percent), (100 mg/d, 50 percent), and (200 mg/d, 100 percent). The mean value is $112.5 \mathrm{mg} / \mathrm{d}$, which agrees well with the value of $100 \mathrm{mg} / \mathrm{d}$ recommended by the EPA and used in other assessment models (Table 6-22). The mean value of the distribution can be obtained by calculating the probability density function $f(x)$ for the soil ingestion rate. It consists of the two uniform sections with the values of $0.5 /(100 \mathrm{mg} / \mathrm{d}-50 \mathrm{mg} / \mathrm{d})=0.01 \mathrm{~d} / \mathrm{mg}$ for the range from 50 to $100 \mathrm{mg} / \mathrm{d}$ and $0.5 /(200 \mathrm{mg} / \mathrm{d}-100 \mathrm{mg} / \mathrm{d})=0.005 \mathrm{~d} / \mathrm{mg}$ for the range from 100 to $200 \mathrm{mg} / \mathrm{d}$. 
Table 6-22. Inadvertent Soil Ingestion Rates Reported in the Literature

\begin{tabular}{|c|c|c|}
\hline Reference & Soil Ingestion Rate & Comments \\
\hline \multicolumn{3}{|c|}{ Direct Measurements } \\
\hline $\begin{array}{l}\text { Calabrese et al. (1990) } \\
\text { as cited in EPA (1997 } \\
\text { [DIRS 103038], p. 4-21) and in } \\
\text { Simon (1998 [DIRS 160098], } \\
\text { p. 652) }\end{array}$ & $\begin{array}{l}30-100 \mathrm{mg} / \mathrm{d} \\
\text { approximately } 50 \mathrm{mg} / \mathrm{d}\end{array}$ & $\begin{array}{l}\text { Based on soil trace element } \\
\text { measurements in } 6 \text { adults; } \\
\text { uncertainties due to small sample } \\
\text { size and short duration of the study }\end{array}$ \\
\hline $\begin{array}{l}\text { Stanek et al. (1997 } \\
\text { [DIRS 160251], p. 249) }\end{array}$ & $\begin{array}{l}10 \mathrm{mg} / \mathrm{d} \text { average; SD = } 94 \mathrm{mg} / \mathrm{d} ; 95 \% \\
\text { value } 331 \mathrm{mg} / \mathrm{d}\end{array}$ & $\begin{array}{l}\text { Based on the soil trace element } \\
\text { measurements for } 10 \text { adults; lower } \\
\text { level of soil ingestion in adults than } \\
\text { estimated previously }\end{array}$ \\
\hline \multicolumn{3}{|c|}{ Assessments, Estimate, and Literature Reviews } \\
\hline $\begin{array}{l}\text { Calabrese (1987) as cited in } \\
\text { EPA (1997 [DIRS 103038], } \\
\text { p. 4-17) }\end{array}$ & 1 to $100 \mathrm{mg} / \mathrm{d}$ & $\begin{array}{l}\text { Suggested values are conjectural } \\
\text { and based on fractional estimates } \\
\text { of earlier Center for Disease } \\
\text { Control estimates. }\end{array}$ \\
\hline $\begin{array}{l}\text { Finley and Paustenbach } \\
\text { (1994) as cited in Simon (1998 } \\
\text { [DIRS 160098], p. 653) }\end{array}$ & $\begin{array}{l}0.1 \text { to } 50 \mathrm{mg} / \mathrm{d} \text { for people aged 13-30 } \\
\text { year }\end{array}$ & $\begin{array}{l}\text { Theoretical assessment } \\
\text { calculations for exposure to dioxin } \\
\text { contamination }\end{array}$ \\
\hline $\begin{array}{l}\text { Hawley (1985) as cited in EPA } \\
\text { (1997 [DIRS 103038], p. 4-17) } \\
\text { and in Simon (1998 } \\
\text { [DIRS 160098], p. 652) }\end{array}$ & $\begin{array}{l}480 \mathrm{mg} / \mathrm{d} \text { for adults engaged in outdoor } \\
\text { activities } \\
0.56 \mathrm{mg} / \mathrm{d} \text { for ingesting house dust during } \\
\text { typical living space activities } \\
110 \mathrm{mg} / \mathrm{d} \text { for ingestion of house dust } \\
\text { while working in attics } \\
60.5 \mathrm{mg} / \mathrm{d} \text { estimated annual average soil } \\
\text { intake rate }\end{array}$ & $\begin{array}{l}\text { Estimated values based on } \\
\text { assumptions about soil and dust } \\
\text { levels on hands and mouthing } \\
\text { behavior. }\end{array}$ \\
\hline $\begin{array}{l}\text { Kimbrough et al. (1984) as } \\
\text { cited in Simon (1998 } \\
\text { [DIRS 160098], p. 652) }\end{array}$ & $\begin{array}{l}100 \mathrm{mg} / \mathrm{d} \text { for people aged more than } 5 \\
\text { years }\end{array}$ & $\begin{array}{l}\text { Theoretical assessment } \\
\text { calculations for exposure to dioxin } \\
\text { contamination }\end{array}$ \\
\hline $\begin{array}{l}\text { Martin and Bloom (1975) as } \\
\text { cited in Simon (1998 } \\
\text { [DIRS 160098], p. 652) }\end{array}$ & $8-11 \mathrm{mg} / \mathrm{d}$ & $\begin{array}{l}\text { Theoretical assessment } \\
\text { calculations for desert environment }\end{array}$ \\
\hline $\begin{array}{l}\text { Sheppard (1995) as cited in } \\
\text { Simon (1998 [DIRS 160098], } \\
\text { p. 654) }\end{array}$ & $\begin{array}{l}20 \mathrm{mg} / \mathrm{d} \text { for adult gardener } \\
0.4 \mathrm{mg} / \mathrm{d} \text { for adult indoors }\end{array}$ & Based on literature review \\
\hline \multicolumn{3}{|c|}{ Recommendations } \\
\hline $\begin{array}{l}\text { ATSDR (1992) as cited in } \\
\text { Simon (1998 [DIRS 160098], } \\
\text { p. 653) }\end{array}$ & $50 \mathrm{mg} / \mathrm{d}$ & \\
\hline $\begin{array}{l}\text { EPA (1997 [DIRS 103038], p. } \\
4-21)\end{array}$ & $\begin{array}{l}50 \mathrm{mg} / \mathrm{d} \text { for industrial settings; a } \\
\text { reasonable central estimate of adult soil } \\
\text { ingestion and the recommended generic } \\
\text { value for soil ingestion } \\
100 \mathrm{mg} / \mathrm{d} \text { for residential and agricultural } \\
\text { scenarios }\end{array}$ & \\
\hline $\begin{array}{l}\text { Various dose/risk assessment } \\
\text { models as described in Simon } \\
\text { (1998 [DIRS 160098], p. 664) }\end{array}$ & $100 \mathrm{mg} / \mathrm{d}$ & $\begin{array}{l}\text { The default value recommended for } \\
\text { dose assessment models, such as } \\
\text { GENII, and RESRAD }\end{array}$ \\
\hline $\begin{array}{l}\text { Simon (1998 [DIRS 160098], } \\
\text { Table 4) }\end{array}$ & $\begin{array}{l}\text { Lognormal distribution } \\
\text { GM from } 50 \text { to } 200 \mathrm{mg} / \mathrm{d} \text { depending on } \\
\text { the environment } \\
\text { GSD }=3.2\end{array}$ & $\begin{array}{l}\text { Recommended distributions are for } \\
\text { occupations on sparsely to heavily } \\
\text { vegetated pasture land and for rural } \\
\text { lifestyles on sparsely to heavily } \\
\text { vegetated land. }\end{array}$ \\
\hline
\end{tabular}

ATSDR = Agency for Toxic Substances and Disease Registry; EPA = Environmental Protection Agency;

$\mathrm{GM}=$ geometric mean; GSD=geometric standard deviation 
The mean value is calculated as

$$
\begin{aligned}
& \int_{50}^{100} 0.01 x d x+\int_{100}^{200} 0.005 x d x=0.01\left[0.5 x^{2}\right]_{50}^{100}+0.005\left[0.5 x^{2}\right]_{100}^{200}= \\
& =0.01 \times 0.5[10000-2500]+0.005 \times 0.5[40000-10000]=112.5
\end{aligned}
$$

Because there are few direct measurements of inadvertent soil ingestion by adults, EPA (1997 [DIRS 103038], p. 4-21) indicates that the recommended values of inadvertent soil ingestion are uncertain. Therefore it is recommended that the same distribution of soil ingestion rate be used for all population groups, all environments, both exposure scenarios, and for the present-day and future climates. The recommended uncertainty distribution sufficiently represents the range of possible values.

\subsection{DOSIMETRY CONSIDERATIONS}

The function of the biosphere model is to calculate doses resulting from the radiation exposure of the receptor. This is accomplished by evaluating radionuclide intake or external exposure of the receptor, which are subsequently converted to radiation doses. The conversion is based on radionuclide-specific DCFs for internal exposure (inhalation or ingestion) and dose coefficients for external exposure. This section develops or recommends the values of conversion factors for the use in the biosphere model.

\subsubsection{Radionuclides and Elements Included in the Analysis}

The biosphere model calculates BDCFs for 28 primary radionuclides (BSC 2004 [DIRS 169460], Section 6.1.3). The list includes radionuclides that are potentially significant dose contributors during the compliance period (up to 10,000 years) and the period of up to 1,000,000 years for both exposure scenarios.

Some of the radionuclides included in the biosphere model are accompanied in the source (e.g., groundwater or volcanic ash) by long-lived decay products, which are not individually tracked in the TSPA model. The biosphere model accounts for exposures to these radionuclides. In the biosphere model, the decay products of primary radionuclides with half-lives less than 180 days are assumed to be in secular equilibrium with the parent radionuclides, and their contributions to the BDCFs are included in the BDCF for the primary radionuclide (BSC 2004 [DIRS 169460], Section 6.3.5). The decay products of primary radionuclides with half-lives longer than 180 days are treated like primary radionuclides (BSC 2004 [DIRS 169460], Section 6.3.5). Three such radionuclides, ${ }^{228} \mathrm{Th},{ }^{228} \mathrm{Ra}$, and ${ }^{235} \mathrm{U}$ were added to the list, resulting in a set of thirty-one radionuclides (Table 6-23). This table also lists the short-lived (half-life less than 180 days) decay products as well as the half-lives and branching fractions for the primary radionuclides and their decay products. Detailed discussion of the treatment of decay products in the biosphere model is presented in BSC (2004 [DIRS 169460], Sections 6.3 .5 and 6.4.1.2). 
Table 6-23. Primary Radionuclides and Their Decay Products Included in the Biosphere Model

\begin{tabular}{|c|c|c|c|}
\hline Primary Radionuclide & $\begin{array}{c}\text { Short-lived Decay } \\
\text { Product }\end{array}$ & Branching Fraction, $\%^{a}$ & Half-life ${ }^{a}$ \\
\hline Carbon-14 $\left({ }^{14} \mathrm{C}\right)$ & & 100 & $5.730 \mathrm{E}+03 \mathrm{yr}$ \\
\hline Chlorine-36 $\left({ }^{36} \mathrm{Cl}\right)$ & & 100 & $3.01 \mathrm{E}+05 \mathrm{yr}$ \\
\hline Selenium-79 $\left({ }^{79} \mathrm{Se}\right)$ & & 100 & $6.50 \mathrm{E}+04 \mathrm{yr}$ \\
\hline \multirow[t]{2}{*}{ Strontium-90 $\left({ }^{90} \mathrm{Sr}\right)$} & & 100 & $2.912 \mathrm{E}+01 \mathrm{yr}$ \\
\hline & Yttrium-90 $\left({ }^{90} \mathrm{Y}\right)$ & 100 & $6.40 \mathrm{E}+01 \mathrm{hr}$ \\
\hline Technetium-99 $\left({ }^{99} \mathrm{Tc}\right)$ & & 100 & $2.13 \mathrm{E}+05 \mathrm{yr}$ \\
\hline \multirow[t]{3}{*}{$\operatorname{Tin}-126\left({ }^{126} \mathrm{Sn}\right)$} & & 100 & $1.0 \mathrm{E}+05 \mathrm{yr}$ \\
\hline & Antimony-126m $\left({ }^{126 \mathrm{~m}} \mathrm{Sb}\right)$ & 100 & $1.90 \mathrm{E}+01 \mathrm{~min}$ \\
\hline & Antimony-126 $\left({ }^{126} \mathrm{Sb}\right)$ & 14 & $1.24 \mathrm{E}+01 \mathrm{~d}$ \\
\hline lodine-129 $\left({ }^{129} \mathrm{I}\right)$ & & 100 & $1.57 \mathrm{E}+07 \mathrm{yr}$ \\
\hline Cesium-135 $\left({ }^{135} \mathrm{Cs}\right)$ & & 100 & $2.3 \mathrm{E}+06 \mathrm{yr}$ \\
\hline \multirow[t]{2}{*}{ Cesium-137 $\left({ }^{137} \mathrm{Cs}\right)$} & & 100 & $3.00 \mathrm{E}+01 \mathrm{yr}$ \\
\hline & Barium-137m $\left({ }^{137 \mathrm{~m}} \mathrm{Ba}\right)$ & 94.60 & $2.552 \mathrm{E}+00 \mathrm{~min}$ \\
\hline \multicolumn{4}{|c|}{ Thorium Series (4n) } \\
\hline Plutonium-240 $\left({ }^{240} \mathrm{Pu}\right)$ & & 100 & $6.537 \mathrm{E}+03 \mathrm{yr}$ \\
\hline Uranium-236 $\left({ }^{236} \mathrm{U}\right)$ & & 100 & $2.3415 \mathrm{E}+07 \mathrm{yr}$ \\
\hline Thorium-232 $\left({ }^{232} \mathrm{Th}\right)$ & & 100 & $1.405 \mathrm{E}+10 \mathrm{yr}$ \\
\hline \multirow[t]{2}{*}{ Radium-228 $\left({ }^{228} \mathrm{Ra}\right)$} & & 100 & $5.75 \mathrm{E}+00 \mathrm{yr}$ \\
\hline & Actinium-228 $\left({ }^{228} \mathrm{Ac}\right)$ & 100 & $6.13 \mathrm{E}+00 \mathrm{hr}$ \\
\hline Uranium-232 $\left({ }^{232} \mathrm{U}\right)$ & & 100 & $7.2 \mathrm{E}+01 \mathrm{yr}$ \\
\hline \multirow[t]{8}{*}{ Thorium-228 $\left({ }^{228} \mathrm{Th}\right)$} & & 100 & $1.9131 \mathrm{E}+00 \mathrm{yr}$ \\
\hline & Radium-224 $\left({ }^{224} \mathrm{Ra}\right)$ & 100 & $3.66 E+00 d$ \\
\hline & Radon-220 ( $\left.{ }^{220} \mathrm{Rn}\right)$ & 100 & $5.56 \mathrm{E}+01 \mathrm{~s}$ \\
\hline & Polonium-216 $\left({ }^{216} \mathrm{Po}\right)$ & 100 & $1.5 \mathrm{E}-01 \mathrm{~s}$ \\
\hline & Lead-212 $\left({ }^{212} \mathrm{~Pb}\right)$ & 100 & $1.064 \mathrm{E}+01 \mathrm{hr}$ \\
\hline & Bismuth-212 $\left({ }^{212} \mathrm{Bi}\right)$ & 100 & $6.055 \mathrm{E}+01 \mathrm{~min}$ \\
\hline & Polonium-212 ( $\left.{ }^{212} \mathrm{Po}\right)$ & 64.07 & 3.05E-07 s \\
\hline & Thallium-208 (208 $\mathrm{TI})$ & 35.93 & $3.07 \mathrm{E}+00 \mathrm{~min}$ \\
\hline \multicolumn{4}{|c|}{ Neptunium Series $(4 n+1)$} \\
\hline Americium-241 $\left({ }^{241} \mathrm{Am}\right)$ & & 100 & $4.322 \mathrm{E}+02 \mathrm{yr}$ \\
\hline \multirow[t]{2}{*}{ Neptunium-237 $\left({ }^{237} \mathrm{~Np}\right)$} & & 100 & $2.14 \mathrm{E}+06 \mathrm{yr}$ \\
\hline & Protactinium-233 $\left({ }^{233} \mathrm{~Pa}\right)$ & 100 & $2.70 E+01 d$ \\
\hline Uranium-233 $\left({ }^{233} \mathrm{U}\right)$ & & 100 & $1.585 \mathrm{E}+05 \mathrm{yr}$ \\
\hline \multirow[t]{9}{*}{ Thorium-229 $\left({ }^{229} \mathrm{Th}\right)$} & & 100 & $7.340 \mathrm{E}+03 \mathrm{yr}$ \\
\hline & Radium-225 $\left({ }^{225} \mathrm{Ra}\right)$ & 100 & $1.48 \mathrm{E}+01 \mathrm{~d}$ \\
\hline & Actinium-225 $\left({ }^{225} \mathrm{Ac}\right)$ & 100 & $1.00 E+01 d$ \\
\hline & Francium-221 $\left({ }^{221} \mathrm{Fr}\right)$ & 100 & $4.8 \mathrm{E}+00 \mathrm{~min}$ \\
\hline & Astatine-217 $\left({ }^{217} \mathrm{At}\right)$ & 100 & $3.23 \mathrm{E}-02 \mathrm{~s}$ \\
\hline & Bismuth-213 $\left({ }^{213} \mathrm{Bi}\right)$ & 100 & $4.565 \mathrm{E}+01 \mathrm{~min}$ \\
\hline & Polonium-213 $\left({ }^{213} \mathrm{Po}\right)$ & 97.84 & 4.2E-06 s \\
\hline & Thallium-209 $\left({ }^{209} \mathrm{TI}\right)$ & 2.16 & $2.20 \mathrm{E}+00 \mathrm{~min}$ \\
\hline & Lead-209 $\left({ }^{209} \mathrm{~Pb}\right)$ & 100 & $3.253 \mathrm{E}+00 \mathrm{hr}$ \\
\hline
\end{tabular}


Characteristics of the Receptor for the Biosphere Model

Table 6-23. Primary Radionuclides and Their Decay Products Included in the Biosphere Model (Continued)

\begin{tabular}{|c|c|c|c|}
\hline Primary Radionuclide & $\begin{array}{c}\text { Short-lived Decay } \\
\text { Product }\end{array}$ & Branching Fraction, $\%^{a}$ & Half-life $^{a}$ \\
\hline \multicolumn{4}{|c|}{ Uranium Series $(4 n+2)$} \\
\hline Plutonium-242 $\left({ }^{242} \mathrm{Pu}\right)$ & & 100 & $3.763 \mathrm{E}+05 \mathrm{yr}$ \\
\hline \multirow[t]{4}{*}{ Uranium-238 $\left({ }^{238} \mathrm{U}\right)$} & & 100 & $4.468 \mathrm{E}+09 \mathrm{yr}$ \\
\hline & Thorium-234 $\left({ }^{234} \mathrm{Th}\right)$ & 100 & $2.410 E+01 d$ \\
\hline & $\begin{array}{l}\text { Protactinium-234m } \\
\left({ }^{234 m} \mathrm{~Pa}\right)\end{array}$ & 99.80 & $1.17 \mathrm{E}+00 \mathrm{~min}$ \\
\hline & Protactinium-234 $\left({ }^{234} \mathrm{~Pa}\right)$ & 0.33 & $6.70 \mathrm{E}+00 \mathrm{hr}$ \\
\hline Plutonium-238 $\left({ }^{238} \mathrm{Pu}\right)$ & & 100 & $8.774 \mathrm{E}+01 \mathrm{yr}$ \\
\hline Uranium-234 $\left({ }^{234} \mathrm{U}\right)$ & & 100 & $2.445 \mathrm{E}+05 \mathrm{yr}$ \\
\hline Thorium-230 $\left({ }^{230} \mathrm{Th}\right)$ & & 100 & $7.7 \mathrm{E}+04 \mathrm{yr}$ \\
\hline \multirow[t]{8}{*}{ Radium-226 $\left({ }^{226} \mathrm{Ra}\right)$} & & 100 & $1.600 \mathrm{E}+03 \mathrm{yr}$ \\
\hline & Radon-222 $\left({ }^{222} \mathrm{Rn}\right)$ & 100 & $3.8235 E+00 d$ \\
\hline & Polonium-218 $\left({ }^{218} \mathrm{Po}\right)$ & 100 & $3.05 \mathrm{E}+00 \mathrm{~min}$ \\
\hline & Lead-214 $\left({ }^{214} \mathrm{~Pb}\right)$ & 99.98 & $2.68 \mathrm{E}+01 \mathrm{~min}$ \\
\hline & Astatine-218 $\left({ }^{218} \mathrm{At}\right)$ & 0.02 & $2 . E+00 s$ \\
\hline & Bismuth-214 $\left({ }^{214} \mathrm{Bi}\right)$ & 100 & 1.99E+01 $\mathrm{min}$ \\
\hline & Polonium-214 $\left({ }^{214} \mathrm{Po}\right)$ & 99.98 & $1.643 \mathrm{E}-04 \mathrm{~s}$ \\
\hline & Thallium-210 $\left({ }^{210} \mathrm{TI}\right)$ & 0.02 & $1.3 \mathrm{E}+00 \mathrm{~min}^{\mathrm{b}}$ \\
\hline \multirow[t]{3}{*}{ Lead-210 $\left({ }^{210} \mathrm{~Pb}\right)$} & & 100 & $2.23 \mathrm{E}+01 \mathrm{yr}$ \\
\hline & Bismuth-210 $\left({ }^{210} \mathrm{Bi}\right)$ & 100 & $5.012 E+00 d$ \\
\hline & Polonium-210 $\left({ }^{210} \mathrm{Po}\right)$ & 100 & $1.3838 \mathrm{E}+02 \mathrm{~d}$ \\
\hline \multicolumn{4}{|c|}{ Actinium Series $(4 n+3)$} \\
\hline \multirow[t]{2}{*}{ Americium-243 $\left({ }^{243} \mathrm{Am}\right)$} & & 100 & $7.380 \mathrm{E}+03 \mathrm{yr}$ \\
\hline & Neptunium-239 (239 $\mathrm{Np})$ & 100 & $2.355 \mathrm{E}+00 \mathrm{~d}$ \\
\hline Plutonium-239 $\left({ }^{239} \mathrm{Pu}\right)$ & & 100 & $2.4065 \mathrm{E}+04 \mathrm{yr}$ \\
\hline \multirow[t]{2}{*}{ Uranium-235 $\left({ }^{235} \mathrm{U}\right)$} & & 100 & $7.038 \mathrm{E}+08 \mathrm{yr}$ \\
\hline & Thorium-231 $\left({ }^{231} \mathrm{Th}\right)$ & 100 & $2.552 \mathrm{E}+01 \mathrm{hr}$ \\
\hline Protactinium-231 $\left({ }^{231} \mathrm{~Pa}\right)$ & & 100 & $3.276 \mathrm{E}+04 \mathrm{yr}$ \\
\hline \multirow[t]{10}{*}{ Actinium-227 $\left({ }^{227} \mathrm{Ac}\right)$} & & 100 & $2.1773 \mathrm{E}+01 \mathrm{yr}$ \\
\hline & Thorium-227 $\left({ }^{227} \mathrm{Th}\right)$ & 98.62 & $1.8718 \mathrm{E}+01 \mathrm{~d}$ \\
\hline & Francium-223 $\left({ }^{223} \mathrm{Fr}\right)$ & 1.38 & $2.18 \mathrm{E}+01 \mathrm{~min}$ \\
\hline & Radium-223 $\left({ }^{223} \mathrm{Ra}\right)$ & 100 & $1.1434 \mathrm{E}+01 \mathrm{~d}$ \\
\hline & Radon-219 $\left({ }^{219} \mathrm{Rn}\right)$ & 100 & $3.96 \mathrm{E}+00 \mathrm{~s}$ \\
\hline & Polonium-215 $\left({ }^{215} \mathrm{Po}\right)$ & 100 & $1.78 \mathrm{E}-03 \mathrm{~s}$ \\
\hline & Lead-211 $\left({ }^{211} \mathrm{~Pb}\right)$ & 100 & $3.61 \mathrm{E}+01 \mathrm{~min}$ \\
\hline & Bismuth-211 ( $\left({ }^{211} \mathrm{Bi}\right)$ & 100 & $2.14 \mathrm{E}+00 \mathrm{~min}$ \\
\hline & Thallium-207 $\left({ }^{207} \mathrm{TI}\right)$ & 99.72 & $4.77 \mathrm{E}+00 \mathrm{~min}$ \\
\hline & Polonium-211 $\left({ }^{211} \mathrm{Po}\right)$ & 0.28 & $5.16 \mathrm{E}-01 \mathrm{~s}$ \\
\hline
\end{tabular}

Sources:

a Eckerman and Ryman 1993 (DIRS 107684), Table A.1.

${ }^{\text {b }}$ Lide and Frederikse 1997 (DIRS 103178), p. 11-125.

NOTE: Short-lived decay products of primary radionuclides are assumed to be in secular equilibrium with their parents. 


\subsubsection{Dosimetric Approaches}

To demonstrate compliance with licensing regulations (10 CFR 63.311 [DIRS 156605]), the results of performance assessment are compared with the individual protection standard expressed in terms of the annual dose. The annual dose in 10 CFR 63.311 [DIRS 156605] is equivalent to the TEDE from annual exposure (66 FR 55732 [DIRS 156671], pp. 55734 to 55735). The TEDE is the quantity typically used to specify dose limits for occupational exposure and is defined in 10 CFR 20.1003 [DIRS 104787] as the sum of deep dose equivalent resulting from exposure to external radiation and the committed effective dose equivalent (CEDE) resulting from internal contamination. For assessing doses to the RMEI, the TEDE is the sum of the effective dose equivalent (EDE) for external exposures and the CEDE for internal exposures (10 CFR 63.2 [DIRS 156605]). The use of the EDE in place of the deep dose equivalent in dose assessment is consistent with NRC guidance (NRC 2003 [DIRS 163018]). The TEDE from annual exposure used in 10 CFR Part 63 [DIRS 156605] is also equivalent to the annual CEDE used by EPA in the individual protection standard (40 CFR 197.20 [DIRS 155238]). The annual CEDE as defined by EPA is the sum of the CEDE from internal doses resulting from 1 year of intake of radioactive materials plus the EDE from external radiation exposure during the year.

CEDE is defined by the NRC as the "sum of the products of the weighting factors applicable to each of the body organs or tissues that are irradiated and the committed dose equivalent to those organs or tissues” (10 CFR 20.1003 [DIRS 104787]). In determining annual TEDE for assessing doses to members of the public (10 CFR Part 63 [DIRS 156605]), the external dose component (EDE) also involves summing the products of organ doses and weighting factors (66 FR 55732 [DIRS 156671], pp. 55734 to 55735).

Calculating CEDE and EDE involves using exposure-to-dose conversion factors, more commonly referred to as DCFs or dose coefficients. The exposure-to-dose conversion factor is one of the fundamental representations of a dosimetric model used in assessing potential radiation dose. It allows an intake of, or exposure to, a radionuclide to be converted to radiation dose. The current approach uses dosimetric models based on the concepts recommended in ICRP Publication 26 (ICRP 1977 [DIRS 101075]) and the dosimetric methods outlined in ICRP Publication 30 (ICRP 1979 [DIRS 110386]; ICRP 1980 [DIRS 110351]; ICRP 1981 [DIRS 110352]). This is consistent with the individual protection standard defined in terms of TEDE and with the NRC guidance on performance assessment methodology (NRC 2000 [DIRS 157704], Section 3.3.7.1.2). The ICRP-26 and ICRP-30 concepts and methods were used by the EPA to calculate the exposure-to-dose conversion factors for inhalation and ingestion presented in FGR No. 11 (Eckerman et al. 1988 [DIRS 101069]) and also dose coefficients for external exposure in FGR No. 12 (Eckerman and Ryman 1993 [DIRS 107684]). Although the DCFs and dose coefficients may have considerable uncertainty due to variability in human physiological characteristics, in this analysis they are taken as fixed values, as given in FGR No. 11 and FGR No. 12. This approach is recommended by the NRC (2000 [DIRS 157704], Sections 3.3.7.3.1 and 3.3.7.3.2) for performance assessments. The biokinetic and dosimetric models used to develop the values in FGR No. 11 and FGR No. 12 are based on the standard representation of adult persons (Eckerman et al. 1988 [DIRS 101069], p. 12; Eckerman and Ryman 1993 [DIRS 107684], p. 9). 
After the incorporation of ICRP-26 and ICRP-30 methodology into various U.S. regulations, the ICRP introduced new recommendations and issued a new set of exposure-to-dose conversion factors in ICRP Publication 72 (ICRP 1996 [DIRS 152446]). This set is based on updated biokinetic data and models, and the revised method for computing radiation doses presented in ICRP Publication 60 (ICRP 1991 [DIRS 101836]). ICRP Publication 60 introduced a new dosimetric quantity, the effective dose, which considers an expanded list of tissues and organs, updated biokinetic data and models, and revised tissue and organ weighting factors. To date, the revised ICRP dosimetric methods and the new exposure-to-dose conversion factors have not been incorporated into United States regulations. Because the repository licensing rule uses the concept of TEDE for dose limits, the conversion factors must also be expressed in terms of CEDE and EDE, which are based on the ICRP-30 dosimetric methods. Therefore, the updated conversion factors were not used.

\subsubsection{Dose Coefficients for Internal and External Exposure}

The primary sources of DCFs for internal and external exposure are FGR No. 11 (Eckerman et al. 1988 [DIRS 101069]) and FGR No. 12 (Eckerman and Ryman 1993 [DIRS 107684]), respectively.

\subsubsection{Dose Conversion Factors for Inhalation and Ingestion}

The DCFs for radionuclide intake by inhalation and ingestion used in the biosphere model are based on the values from FGR No. 11 (Eckerman et al. 1988 [DIRS 101069]). The DCFs for inhalation are for particles with activity median aerodynamic diameter (AMAD) of $1 \mu \mathrm{m}$. For many radionuclides, there is only one DCF value for inhalation and one for ingestion. For some radionuclides, FGR No. 11 gives more than one value of DCF corresponding to different chemical compounds. Different DCFs arise from different fractional uptakes of a radionuclide from the small intestine to the blood and different lung clearance classes (ICRP 1979 [DIRS 110386], p. 24 and 30 to 31) for various chemical forms of the radionuclide. DCFs for radionuclide intake by inhalation and ingestion were selected such that they correspond to the most conservative conditions for radionuclides under consideration. For most of the radionuclides considered in the biosphere model, if a radionuclide has more than one DCF, the higher DCF is for more soluble compounds. One exception is uranium, for which inhalation DCFs are the highest for the lung clearance class Y (long retention, on the order of years, in the pulmonary region of the lung) and relatively low uptake to blood. In this case, the highest DCF for inhalation and ingestion correspond to different chemical forms of a radionuclide. Despite this inconsistency, selecting the highest DCF value for a radionuclide ensures that the doses from this radionuclide will not be underestimated regardless of the chemical form of the radionuclide in the environment. The NRC (NRC 2000 [DIRS 157704], Section 3.3.7.3.1) recommends using the most conservative internal DCFs for TEDE calculations for radionuclides that have multiple DCFs based on chemical form, unless a particular chemical form can be justified.

The inhalation DCF for carbon dioxide was selected for ${ }^{14} \mathrm{C}$ (Table 6-24). The value for carbon dioxide is not the highest DCF for carbon (the value for labeled organic compounds is higher), but was selected because carbon dioxide is the chemical form for ${ }^{14} \mathrm{C}$ inhalation. 
For ${ }^{90} \mathrm{Sr}$, it is customary to not select the highest DCF for inhalation. The most conservative DCF value for inhalation of strontium is for $\mathrm{SrTiO}_{3}$, which is rare and is considered to be unattainable during transport through environmental media (Rittmann 1993 [DIRS 107744], p. 6). Therefore, the value for other, more common chemical forms of strontium are used for inhalation and ingestion. Table 6-24 contains a summary of the DCFs for inhalation and ingestion that are recommended for use in the biosphere model.

It is customary in radiological assessments that the DCFs for inhalation and ingestion are represented by fixed values and the same approach is recommended for the biosphere model although there are many sources of uncertainty associated with the dosimetric models. These uncertainties are described in NCRP Commentary No. 15 (NCRP 1998 [DIRS 160160]). Specifically, the estimated reliability of the DCFs for inhalation and ingestion based on ICRP-30 methodology can be found in the NCRP Commentary (NCRP 1998 [DIRS 160160], Table 8.2). The results of the NCRP evaluation indicate that for many radionuclides considered in this analysis, the DCFs are poorly known and that the true values for at least 90 percent of the population may be as much as a factor of 10 higher or lower than the values recommended by ICRP in Publication 30 (NCRP 1998 [DIRS 160160], Table 8.2).

\subsubsection{Dose Coefficients for Exposure to Contaminated Soil}

The source of dose coefficients for exposure to contaminated soil is FGR No. 12 (Eckerman and Ryman 1993 [DIRS 107684]). From this report, the biosphere model uses dose coefficients for exposure to contaminated ground surface and to soil contaminated to an infinite depth. These dose coefficients are listed in Table 6-25.

\subsubsection{Dose Coefficients for Air Submersion and Water Immersion}

Dose coefficients for external exposure to radionuclides in air (air submersion) and in water (water immersion) recommended for use in the biosphere model are listed in Table 6-26. The source of these dose coefficients is FGR No. 12 (Eckerman and Ryman 1993 [DIRS 107684]). These dose coefficients are used in the Biosphere Model Report (BSC 2004 [DIRS 169460], Section 7.4) to evaluate the consequences of air submersion and water immersion, but are not directly used in the ERMYN model. 
Table 6-24. Dose Conversion Factors for Inhalation and Ingestion of Radionuclides of Interest

\begin{tabular}{|c|c|c|c|}
\hline \multirow[b]{2}{*}{ Primary Radionuclide } & \multirow{2}{*}{$\begin{array}{l}\text { Short-lived Decay } \\
\text { Product }\end{array}$} & \multicolumn{2}{|c|}{ Dose Conversion Factors (Sv/Bq) } \\
\hline & & Inhalation & Ingestion \\
\hline Carbon-14 $\left({ }^{14} \mathrm{C}\right)\left(\right.$ as $\left.\mathrm{CO}_{2}\right)$ & & $6.36 \mathrm{E}-12$ & $5.64 \mathrm{E}-10$ \\
\hline Chlorine-36 $\left({ }^{36} \mathrm{Cl}\right)$ & & 5.93E-09 & $8.18 \mathrm{E}-10$ \\
\hline Selenium-79 $\left({ }^{79} \mathrm{Se}\right)$ & & $2.66 \mathrm{E}-09$ & 2.35E-09 \\
\hline \multirow[t]{2}{*}{ Strontium-90 $\left({ }^{90} \mathrm{Sr}\right)$} & & $6.47 \mathrm{E}-08^{\mathrm{a}}$ & 3.85E-08 \\
\hline & Yttrium-90 $\left({ }^{90} \mathrm{Y}\right)$ & 2.28E-09 & 2.91E-09 \\
\hline Technetium-99 $\left({ }^{99} \mathrm{Tc}\right)$ & & $2.25 E-09$ & $3.95 \mathrm{E}-10$ \\
\hline \multirow[t]{3}{*}{ Tin-126 ( $\left.{ }^{126} \mathrm{Sn}\right)$} & & $2.69 \mathrm{E}-08$ & $5.27 \mathrm{E}-09$ \\
\hline & Antimony-126m $\left({ }^{126 m} \mathrm{Sb}\right)$ & $9.17 \mathrm{E}-12$ & $2.54 \mathrm{E}-11$ \\
\hline & Antimony-126 $\left({ }^{126} \mathrm{Sb}\right)$ & 3.17E-09 & $2.89 \mathrm{E}-09$ \\
\hline lodine-129 $\left({ }^{129} \mathrm{I}\right)$ & & 4.69E-08 & $7.46 \mathrm{E}-08$ \\
\hline Cesium-135 $\left({ }^{135} \mathrm{Cs}\right)$ & & 1.23E-09 & $1.91 \mathrm{E}-09$ \\
\hline \multirow[t]{2}{*}{ Cesium-137 ( $\left.{ }^{137} \mathrm{Cs}\right)$} & & 8.63E-09 & 1.35E-08 \\
\hline & Barium-137m $\left({ }^{137 m} \mathrm{Ba}\right)$ & $-{ }^{b}$ & $-{ }^{b}$ \\
\hline \multicolumn{4}{|c|}{ Thorium Series (4n) } \\
\hline Plutonium-240 $\left({ }^{240} \mathrm{Pu}\right)$ & & $1.16 \mathrm{E}-04$ & $9.56 \mathrm{E}-07$ \\
\hline Uranium-236 $\left({ }^{236} \mathrm{U}\right)$ & & 3.39E-05 & $7.26 \mathrm{E}-08$ \\
\hline Thorium-232 $\left({ }^{232} \mathrm{Th}\right)$ & & 4.43E-04 & 7.38E-07 \\
\hline \multirow[t]{2}{*}{ Radium-228 $\left({ }^{228} \mathrm{Ra}\right)$} & & 1.29E-06 & $3.88 \mathrm{E}-07$ \\
\hline & Actinium-228 $\left({ }^{228} \mathrm{Ac}\right)$ & 8.33E-08 & $5.85 \mathrm{E}-10$ \\
\hline Uranium-232 $\left({ }^{232} U\right)$ & & $1.78 \mathrm{E}-04$ & 3.54E-07 \\
\hline \multirow[t]{8}{*}{ Thorium-228 $\left({ }^{228} \mathrm{Th}\right)$} & & $9.23 E-05$ & 1.07E-07 \\
\hline & Radium-224 $\left({ }^{224} \mathrm{Ra}\right)$ & $8.53 E-07$ & 9.89E-08 \\
\hline & Radon-220 $\left({ }^{220} \mathrm{Rn}\right)$ & $-{ }^{b}$ & $-{ }^{\mathrm{b}}$ \\
\hline & Polonium-216 $\left({ }^{216} \mathrm{Po}\right)$ & $-{ }^{b}$ & $-{ }^{b}$ \\
\hline & Lead-212 (212 $\mathrm{Pb})$ & $4.56 \mathrm{E}-08$ & $1.23 \mathrm{E}-08$ \\
\hline & Bismuth-212 ( $\left.{ }^{212} \mathrm{Bi}\right)$ & 5.83E-09 & $2.87 \mathrm{E}-10$ \\
\hline & Polonium-212 ( $\left({ }^{212} \mathrm{Po}\right)$ & $-{ }^{\mathrm{b}}$ & $-{ }^{b}$ \\
\hline & Thallium-208 $\left({ }^{208} \mathrm{TI}\right)$ & $-{ }^{\mathrm{b}}$ & $-{ }^{\mathrm{b}}$ \\
\hline \multicolumn{4}{|c|}{ Neptunium Series $(4 n+1)$} \\
\hline Americium-241 $\left({ }^{241} \mathrm{Am}\right)$ & & 1.20E-04 & 9.84E-07 \\
\hline \multirow[t]{2}{*}{ Neptunium-237 $\left({ }^{237} \mathrm{~Np}\right)$} & & 1.46E-04 & $1.20 \mathrm{E}-06$ \\
\hline & Protactinium-233 $\left({ }^{233} \mathrm{~Pa}\right)$ & $2.58 \mathrm{E}-09$ & $9.81 \mathrm{E}-10$ \\
\hline Uranium-233 $\left({ }^{233} \mathrm{U}\right)$ & & $3.66 \mathrm{E}-05$ & 7.81E-08 \\
\hline \multirow[t]{9}{*}{ Thorium-229 $\left({ }^{229} \mathrm{Th}\right)$} & & $5.80 \mathrm{E}-04$ & 9.54E-07 \\
\hline & Radium-225 $\left({ }^{225} \mathrm{Ra}\right)$ & $2.10 \mathrm{E}-06$ & 1.04E-07 \\
\hline & Actinium-225 $\left({ }^{225} \mathrm{Ac}\right)$ & 2.92E-06 & $3.00 \mathrm{E}-08$ \\
\hline & Francium-221 $\left({ }^{221} \mathrm{Fr}\right)$ & $-{ }^{\mathrm{b}}$ & $-{ }^{\mathrm{b}}$ \\
\hline & Astatine-217 $\left({ }^{217} \mathrm{At}\right)$ & $-{ }^{\mathrm{b}}$ & $-{ }^{b}$ \\
\hline & Bismuth-213 $\left({ }^{213} \mathrm{Bi}\right)$ & 4.63E-09 & $1.95 \mathrm{E}-10$ \\
\hline & Polonium-213 $\left({ }^{213} \mathrm{Po}\right)$ & $-{ }^{\mathrm{b}}$ & $-{ }^{\mathrm{b}}$ \\
\hline & Thallium-209 ( $\left.{ }^{209} \mathrm{TI}\right)$ & $-{ }^{b}$ & $-{ }^{b}$ \\
\hline & Lead-209 $\left({ }^{209} \mathrm{~Pb}\right)$ & $2.56 \mathrm{E}-11$ & $5.75 \mathrm{E}-11$ \\
\hline
\end{tabular}


Characteristics of the Receptor for the Biosphere Model

Table 6-24. Dose Conversion Factors for Inhalation and Ingestion of Radionuclides of Interest (Continued)

\begin{tabular}{|c|c|c|c|}
\hline \multirow[t]{2}{*}{ Primary Radionuclide } & \multirow[t]{2}{*}{$\begin{array}{c}\text { Short-lived Decay } \\
\text { Product }\end{array}$} & \multicolumn{2}{|c|}{ Dose Conversion Factors (Sv/Bq) } \\
\hline & & Inhalation & Ingestion \\
\hline \multicolumn{4}{|c|}{ Uranium Series $(4 n+2)$} \\
\hline Plutonium-242 $\left({ }^{242} \mathrm{Pu}\right)$ & & $1.11 \mathrm{E}-04$ & 9.08E-07 \\
\hline \multirow{4}{*}{ Uranium-238 $\left({ }^{238} \mathrm{U}\right)$} & & 3.20E-05 & $6.88 \mathrm{E}-08$ \\
\hline & Thorium-234 $\left({ }^{234} \mathrm{Th}\right)$ & 9.47E-09 & 3.69E-09 \\
\hline & Protactinium-234m $\left({ }^{234 \mathrm{~m}} \mathrm{~Pa}\right)$ & $-{ }^{\mathrm{b}}$ & $-{ }^{\mathrm{b}}$ \\
\hline & Protactinium-234 $\left({ }^{234} \mathrm{~Pa}\right)$ & $2.20 \mathrm{E}-10$ & $5.84 \mathrm{E}-10$ \\
\hline Plutonium-238 $\left({ }^{238} \mathrm{Pu}\right)$ & & 1.06E-04 & $8.65 E-07$ \\
\hline Uranium-234 $\left({ }^{234} \mathrm{U}\right)$ & & 3.58E-05 & $7.66 \mathrm{E}-08$ \\
\hline Thorium-230 $\left({ }^{230} \mathrm{Th}\right)$ & & 8.80E-05 & $1.48 \mathrm{E}-07$ \\
\hline \multirow[t]{8}{*}{ Radium-226 $\left({ }^{226} \mathrm{Ra}\right)$} & & $2.32 \mathrm{E}-06$ & 3.58E-07 \\
\hline & Radon-222 ( $\left.{ }^{222} \mathrm{Rn}\right)$ & $-{ }^{\mathrm{b}}$ & $-{ }^{\mathrm{b}}$ \\
\hline & Polonium-218 $\left({ }^{218} \mathrm{Po}\right)$ & $-{ }^{\mathrm{b}}$ & $-{ }^{\mathrm{b}}$ \\
\hline & Lead-214 $\left({ }^{214} \mathrm{~Pb}\right)$ & $2.11 \mathrm{E}-09$ & $1.69 \mathrm{E}-10$ \\
\hline & Astatine-218 $\left({ }^{218} \mathrm{At}\right)$ & $-{ }^{\mathrm{b}}$ & $-{ }^{\mathrm{b}}$ \\
\hline & Bismuth-214 $\left({ }^{214} \mathrm{Bi}\right)$ & 1.78E-09 & 7.64E-11 \\
\hline & Polonium-214 $\left({ }^{214} \mathrm{Po}\right)$ & $-{ }^{\mathrm{b}}$ & $-{ }^{b}$ \\
\hline & Thallium-210 ( $\left.{ }^{210} \mathrm{TI}\right)$ & $-{ }^{\mathrm{b}}$ & $-{ }^{\mathrm{b}}$ \\
\hline \multirow{3}{*}{ Lead-210 $\left({ }^{210} \mathrm{~Pb}\right)$} & & 3.67E-06 & 1.45E-06 \\
\hline & Bismuth-210 ( $\left.{ }^{210} \mathrm{Bi}\right)$ & 5.29E-08 & 1.73E-09 \\
\hline & Polonium-210 $\left({ }^{210} \mathrm{Po}\right)$ & $2.54 \mathrm{E}-06$ & $5.14 \mathrm{E}-07$ \\
\hline \multicolumn{4}{|c|}{ Actinium Series $(4 n+3)$} \\
\hline \multirow[t]{2}{*}{ Americium-243 $\left({ }^{243} \mathrm{Am}\right)$} & & 1.19E-04 & 9.79E-07 \\
\hline & Neptunium-239 $\left({ }^{239} \mathrm{~Np}\right)$ & $6.78 \mathrm{E}-10$ & $8.82 \mathrm{E}-10$ \\
\hline Plutonium-239 $\left({ }^{239} \mathrm{Pu}\right)$ & & 1.16E-04 & 9.56E-07 \\
\hline \multirow[t]{2}{*}{ Uranium-235 $\left({ }^{235} \mathrm{U}\right)$} & & 3.32E-05 & $7.19 \mathrm{E}-08$ \\
\hline & Thorium-231 $\left({ }^{231} \mathrm{Th}\right)$ & $2.37 \mathrm{E}-10$ & $3.65 \mathrm{E}-10$ \\
\hline Protactinium-231 $\left({ }^{231} \mathrm{~Pa}\right)$ & & 3.47E-04 & $2.86 \mathrm{E}-06$ \\
\hline \multirow[t]{8}{*}{ Actinium-227 $\left({ }^{227} \mathrm{Ac}\right)$} & & $1.81 \mathrm{E}-03$ & 3.80E-06 \\
\hline & Thorium-227 $\left({ }^{227} \mathrm{Th}\right)$ & 4.37E-06 & 1.03E-08 \\
\hline & Francium-223 $\left({ }^{223} \mathrm{Fr}\right)$ & 1.68E-09 & $2.33 \mathrm{E}-09$ \\
\hline & Radium-223 $\left({ }^{223} \mathrm{Ra}\right)$ & $2.12 \mathrm{E}-06$ & 1.78E-07 \\
\hline & Radon-219 $\left({ }^{219} \mathrm{Rn}\right)$ & $-{ }^{\mathrm{b}}$ & $-{ }^{\mathrm{b}}$ \\
\hline & Polonium-215 $\left({ }^{215} \mathrm{Po}\right)$ & $-{ }^{\mathrm{b}}$ & $-{ }^{\mathrm{b}}$ \\
\hline & Lead-211 ( $\left({ }^{211} \mathrm{~Pb}\right)$ & 2.35E-09 & $1.42 \mathrm{E}-10$ \\
\hline & Bismuth-211 $\left({ }^{211} \mathrm{Bi}\right)$ & $-{ }^{\mathrm{b}}$ & $-{ }^{\mathrm{b}}$ \\
\hline \multicolumn{4}{|c|}{ Actinium Series $(4 n+3)$} \\
\hline & Thallium-207 $\left({ }^{207} \mathrm{TI}\right)$ & $-{ }^{\mathrm{b}}$ & $-{ }^{\mathrm{b}}$ \\
\hline & Polonium-211 $\left({ }^{211} \mathrm{Po}\right)$ & $-{ }^{\mathrm{b}}$ & $-{ }^{b}$ \\
\hline
\end{tabular}


Table 6-24. Dose Conversion Factors for Inhalation and Ingestion of Radionuclides of Interest (Continued)

\begin{tabular}{|c|c|c|c|}
\hline \multirow[t]{2}{*}{ Primary Radionuclide } & \multirow[t]{2}{*}{$\begin{array}{c}\text { Short-lived Decay } \\
\text { Product }\end{array}$} & \multicolumn{2}{|c|}{ Dose Conversion Factors (Sv/Bq) } \\
\hline & & Inhalation & Ingestion \\
\hline \multicolumn{4}{|c|}{ Actinium Series $(4 n+3)$} \\
\hline & Thallium-207 $\left({ }^{207} \mathrm{TI}\right)$ & $-{ }^{b}$ & $-{ }^{b}$ \\
\hline & Polonium-211 ( $\left({ }^{211} \mathrm{Po}\right)$ & $-{ }^{\mathrm{b}}$ & $-{ }^{b}$ \\
\hline
\end{tabular}

Source: Eckerman et al. 1988 (DIRS 101069), Tables 2.1 and 2.2.

DCFs are in units of Sv/Bq. $1 \mathrm{~Sv}=100 \mathrm{rem} ; 1 \mathrm{Ci}=3.7 \times 10^{10} \mathrm{~Bq}$.

${ }^{\text {a }}$ Two values of DCF for ${ }^{90} \mathrm{Sr}$ are given in the source document: one for $\mathrm{SrTiO}_{3}$ and one for all other compounds. Because $\mathrm{SrTiO}_{3}$ is not a common compound and is unlikely to be present in the biosphere, the value for all other compounds was used (Rittmann 1993 [DIRS 107744], p. 6).

${ }^{b}$ Eckerman et al. 1988 (DIRS 101069) does not include DCFs for the short-lived radionuclides. The contribution from the short-lived decay products resulting from the decay of a longer lived parent radionuclide in the human body is included together with the parent radionuclide DCF. For radon, the short-lived decay products are included in the DCF for the parent radionuclide, as described in Section 6.5.4. 
Table 6-25. Dose Coefficients for External Exposure to Contaminated Soil for Radionuclides of Interest

\begin{tabular}{|c|c|c|c|}
\hline \multirow[b]{2}{*}{ Primary Radionuclide } & \multirow[b]{2}{*}{$\begin{array}{c}\text { Short-lived Decay } \\
\text { Product }\end{array}$} & \multicolumn{2}{|c|}{ Dose Coefficient } \\
\hline & & $\begin{array}{l}\text { Ground Surface } \\
\text { Svls per Bq/m }\end{array}$ & $\begin{array}{l}\text { Infinite Depth } \\
\text { Svls per Bq/m }\end{array}$ \\
\hline Carbon-14 $\left({ }^{14} \mathrm{C}\right)$ & & 1.61E-20 & $7.20 \mathrm{E}-23$ \\
\hline Chlorine-36 $\left({ }^{36} \mathrm{Cl}\right)$ & & $6.73 E-19$ & $1.28 \mathrm{E}-20$ \\
\hline Selenium-79 $\left({ }^{79} \mathrm{Se}\right)$ & & 2.07E-20 & $9.96 \mathrm{E}-23$ \\
\hline \multirow[t]{2}{*}{ Strontium-90 $\left({ }^{90} \mathrm{Sr}\right)$} & & $2.84 \mathrm{E}-19$ & $3.77 \mathrm{E}-21$ \\
\hline & Yttrium-90 $\left({ }^{90} \mathrm{Y}\right)$ & 5.32E-18 & $1.28 \mathrm{E}-19$ \\
\hline Technetium-99 $\left({ }^{99} \mathrm{Tc}\right)$ & & 7.80E-20 & $6.72 \mathrm{E}-22$ \\
\hline \multirow[t]{3}{*}{$\operatorname{Tin}-126\left({ }^{126} \mathrm{Sn}\right)$} & & $5.47 \mathrm{E}-17$ & 7.89E-19 \\
\hline & Antimony-126m $\left({ }^{126 \mathrm{~m}} \mathrm{Sb}\right)$ & $1.52 \mathrm{E}-15$ & $4.98 \mathrm{E}-17$ \\
\hline & Antimony-126 $\left({ }^{126} \mathrm{Sb}\right)$ & $2.78 \mathrm{E}-15$ & $9.16 \mathrm{E}-17$ \\
\hline lodine-129 $\left({ }^{129} \mathrm{I}\right)$ & & $2.58 \mathrm{E}-17$ & $6.93 \mathrm{E}-20$ \\
\hline Cesium-135 $\left({ }^{135} \mathrm{Cs}\right)$ & & 3.33E-20 & $2.05 E-22$ \\
\hline \multirow[t]{2}{*}{ Cesium-137 $\left({ }^{137} \mathrm{Cs}\right)$} & & 2.85E-19 & 4.02E-21 \\
\hline & Barium-137m $\left({ }^{137 \mathrm{~m}} \mathrm{Ba}\right)$ & $5.86 \mathrm{E}-16$ & 1.93E-17 \\
\hline \multicolumn{4}{|c|}{ Thorium Series $(4 n)$} \\
\hline Plutonium-240 $\left({ }^{240} \mathrm{Pu}\right)$ & & 8.03E-19 & 7.85E-22 \\
\hline Uranium-236 $\left({ }^{236} \mathrm{U}\right)$ & & $6.50 \mathrm{E}-19$ & $1.15 \mathrm{E}-21$ \\
\hline Thorium-232 $\left({ }^{232} \mathrm{Th}\right)$ & & $5.51 \mathrm{E}-19$ & $2.79 \mathrm{E}-21$ \\
\hline \multirow[t]{2}{*}{ Radium-228 $\left({ }^{228} \mathrm{Ra}\right)$} & & $0.00 \mathrm{E}+00$ & $0.00 \mathrm{E}+00$ \\
\hline & Actinium-228 $\left({ }^{228} \mathrm{Ac}\right)$ & $9.28 \mathrm{E}-16$ & $3.20 \mathrm{E}-17$ \\
\hline Uranium-232 $\left({ }^{232} U\right)$ & & $1.01 \mathrm{E}-18$ & $4.83 E-21$ \\
\hline \multirow[t]{8}{*}{ Thorium-228 $\left({ }^{228} \mathrm{Th}\right)$} & & 2.35E-18 & $4.25 E-20$ \\
\hline & Radium-224 $\left({ }^{224} \mathrm{Ra}\right)$ & 9.57E-18 & $2.74 \mathrm{E}-19$ \\
\hline & Radon-220 $\left({ }^{220} \mathrm{Rn}\right)$ & 3.81E-19 & $1.23 E-20$ \\
\hline & Polonium-216 $\left({ }^{216} \mathrm{Po}\right)$ & 1.65E-20 & $5.58 \mathrm{E}-22$ \\
\hline & Lead-212 ( $\left({ }^{212} \mathrm{~Pb}\right)$ & 1.43E-16 & 3.77E-18 \\
\hline & Bismuth-212 $\left({ }^{212} \mathrm{Bi}\right)$ & 1.79E-16 & $6.27 \mathrm{E}-18$ \\
\hline & Polonium-212 (212 $\mathrm{Po})$ & $0.00 \mathrm{E}+00$ & $0.00 \mathrm{E}+00$ \\
\hline & Thallium-208 (208 $\mathrm{TI})$ & $2.98 \mathrm{E}-15$ & 1.23E-16 \\
\hline \multicolumn{4}{|c|}{ Neptunium Series $(4 n+1)$} \\
\hline Americium-241 $\left({ }^{241} \mathrm{Am}\right)$ & & 2.75E-17 & 2.34E-19 \\
\hline \multirow[t]{2}{*}{ Neptunium-237 $\left({ }^{237} \mathrm{~Np}\right)$} & & 2.87E-17 & 4.17E-19 \\
\hline & Protactinium-233 $\left({ }^{233} \mathrm{~Pa}\right)$ & $1.95 \mathrm{E}-16$ & $5.46 \mathrm{E}-18$ \\
\hline Uranium-233 $\left({ }^{233} \mathrm{U}\right)$ & & 7.16E-19 & $7.48 \mathrm{E}-21$ \\
\hline \multirow[t]{9}{*}{ Thorium-229 $\left({ }^{229} \mathrm{Th}\right)$} & & $8.54 \mathrm{E}-17$ & $1.72 \mathrm{E}-18$ \\
\hline & Radium-225 $\left({ }^{225} \mathrm{Ra}\right)$ & 1.33E-17 & $5.90 \mathrm{E}-20$ \\
\hline & Actinium-225 $\left({ }^{225} \mathrm{Ac}\right)$ & $1.58 \mathrm{E}-17$ & 3.41E-19 \\
\hline & Francium-221 $\left({ }^{221} \mathrm{Fr}\right)$ & $2.98 \mathrm{E}-17$ & $8.22 \mathrm{E}-19$ \\
\hline & Astatine-217 ( $\left.{ }^{217} \mathrm{At}\right)$ & 3.03E-19 & $9.49 \mathrm{E}-21$ \\
\hline & Bismuth-213 $\left({ }^{213} \mathrm{Bi}\right)$ & $1.32 \mathrm{E}-16$ & $4.10 \mathrm{E}-18$ \\
\hline & Polonium-213 $\left({ }^{213} \mathrm{Po}\right)$ & $0.00 \mathrm{E}+00$ & $0.00 \mathrm{E}+00$ \\
\hline & Thallium-209 $\left({ }^{209} \mathrm{TI}\right)$ & 1.90E-15 & $6.92 \mathrm{E}-17$ \\
\hline & Lead-209 $\left({ }^{209} \mathrm{~Pb}\right)$ & $3.01 \mathrm{E}-19$ & $4.14 \mathrm{E}-21$ \\
\hline
\end{tabular}


Table 6-25. Dose Coefficients for External Exposure to Contaminated Soil for Radionuclides of Interest (Continued)

\begin{tabular}{|c|c|c|c|}
\hline \multirow[b]{2}{*}{ Primary Radionuclide } & \multirow[b]{2}{*}{$\begin{array}{l}\text { Short-lived Decay } \\
\text { Product }\end{array}$} & \multicolumn{2}{|c|}{ Dose Coefficient } \\
\hline & & $\begin{array}{l}\text { Ground Surface } \\
\text { Svls per Bq/m }\end{array}$ & $\begin{array}{l}\text { Infinite Depth } \\
\text { Sv/s per } \mathrm{Bq} / \mathrm{m}^{3}\end{array}$ \\
\hline \multicolumn{4}{|c|}{ Uranium Series $(4 n+2)$} \\
\hline Plutonium-242 ( $\left({ }^{242} \mathrm{Pu}\right)$ & & $6.67 \mathrm{E}-19$ & $6.85 \mathrm{E}-22$ \\
\hline \multirow[t]{4}{*}{ Uranium-238 $\left({ }^{238} \mathrm{U}\right)$} & & $5.51 \mathrm{E}-19$ & $5.52 \mathrm{E}-22$ \\
\hline & Thorium-234 $\left({ }^{234} \mathrm{Th}\right)$ & $8.32 \mathrm{E}-18$ & 1.29E-19 \\
\hline & Protactinium-234m $\left({ }^{234 \mathrm{~m}} \mathrm{~Pa}\right)$ & 1.53E-17 & $4.80 \mathrm{E}-19$ \\
\hline & Protactinium-234 $\left({ }^{234} \mathrm{~Pa}\right)$ & 1.84E-15 & $6.18 \mathrm{E}-17$ \\
\hline Plutonium-238 $\left({ }^{238} \mathrm{Pu}\right)$ & & 8.38E-19 & $8.10 \mathrm{E}-22$ \\
\hline Uranium-234 $\left({ }^{234} \mathrm{U}\right)$ & & $7.48 \mathrm{E}-19$ & $2.15 E-21$ \\
\hline Thorium-230 $\left({ }^{230} \mathrm{Th}\right)$ & & $7.50 \mathrm{E}-19$ & $6.47 \mathrm{E}-21$ \\
\hline \multirow[t]{8}{*}{ Radium-226 $\left({ }^{226} \mathrm{Ra}\right)$} & & $6.44 \mathrm{E}-18$ & 1.70E-19 \\
\hline & Radon-222 $\left({ }^{222} \mathrm{Rn}\right)$ & 3.95E-19 & $1.26 \mathrm{E}-20$ \\
\hline & Polonium-218 $\left({ }^{218} \mathrm{Po}\right)$ & $8.88 \mathrm{E}-21$ & $3.02 \mathrm{E}-22$ \\
\hline & Lead-214 $\left({ }^{214} \mathrm{~Pb}\right)$ & $2.44 \mathrm{E}-16$ & $7.18 \mathrm{E}-18$ \\
\hline & Astatine-218 $\left({ }^{218} \mathrm{At}\right)$ & $4.18 \mathrm{E}-18$ & $3.13 E-20$ \\
\hline & Bismuth-214 $\left({ }^{214} \mathrm{Bi}\right)$ & $1.41 \mathrm{E}-15$ & $5.25 \mathrm{E}-17$ \\
\hline & Polonium-214 $\left({ }^{214} \mathrm{Po}\right)$ & $8.13 E-20$ & $2.75 \mathrm{E}-21$ \\
\hline & Thallium-210 $\left({ }^{210} \mathrm{TI}\right)$ & $-{ }^{a}$ & $-{ }^{\mathrm{a}}$ \\
\hline \multirow[t]{3}{*}{ Lead-210 ( $\left.{ }^{210} \mathrm{~Pb}\right)$} & & $2.48 \mathrm{E}-18$ & $1.31 \mathrm{E}-20$ \\
\hline & Bismuth-210 $\left({ }^{210} \mathrm{Bi}\right)$ & 1.05E-18 & 1.93E-20 \\
\hline & Polonium-210 $\left({ }^{210} \mathrm{Po}\right)$ & $8.29 \mathrm{E}-21$ & $2.80 \mathrm{E}-22$ \\
\hline \multicolumn{4}{|c|}{ Actinium Series $(4 n+3)$} \\
\hline \multirow[t]{2}{*}{ Americium-243 $\left({ }^{243} \mathrm{Am}\right)$} & & $5.35 \mathrm{E}-17$ & 7.60E-19 \\
\hline & Neptunium-239 $\left({ }^{239} \mathrm{~Np}\right)$ & 1.63E-16 & 4.03E-18 \\
\hline Plutonium-239 $\left({ }^{239} \mathrm{Pu}\right)$ & & 3.67E-19 & $1.58 \mathrm{E}-21$ \\
\hline \multirow[t]{2}{*}{ Uranium-235 $\left({ }^{235} \mathrm{U}\right)$} & & $1.48 \mathrm{E}-16$ & $3.86 \mathrm{E}-18$ \\
\hline & Thorium-231 $\left({ }^{231} \mathrm{Th}\right)$ & $1.85 \mathrm{E}-17$ & 1.95E-19 \\
\hline Protactinium-231 $\left({ }^{231} \mathrm{~Pa}\right)$ & & 4.07E-17 & $1.02 \mathrm{E}-18$ \\
\hline \multirow[t]{10}{*}{ Actinium-227 ( $\left.{ }^{227} \mathrm{Ac}\right)$} & & 1.57E-19 & 2.65E-21 \\
\hline & Thorium-227 $\left({ }^{227} \mathrm{Th}\right)$ & $1.04 \mathrm{E}-16$ & $2.79 \mathrm{E}-18$ \\
\hline & Francium-223 $\left({ }^{223} \mathrm{Fr}\right)$ & $5.65 \mathrm{E}-17$ & $1.06 \mathrm{E}-18$ \\
\hline & Radium-223 $\left({ }^{223} \mathrm{Ra}\right)$ & $1.28 \mathrm{E}-16$ & $3.23 E-18$ \\
\hline & Radon-219 $\left({ }^{219} \mathrm{Rn}\right)$ & $5.49 \mathrm{E}-17$ & 1.65E-18 \\
\hline & Polonium-215 $\left({ }^{215} \mathrm{Po}\right)$ & 1.74E-19 & $5.44 \mathrm{E}-21$ \\
\hline & Lead-211 $\left({ }^{211} \mathrm{~Pb}\right)$ & $5.08 \mathrm{E}-17$ & 1.64E-18 \\
\hline & Bismuth-211 $\left({ }^{211} \mathrm{Bi}\right)$ & $4.58 \mathrm{E}-17$ & $1.37 \mathrm{E}-18$ \\
\hline & Thallium-207 ( $\left.{ }^{207} \mathrm{TI}\right)$ & $3.76 \mathrm{E}-18$ & $1.06 \mathrm{E}-19$ \\
\hline & Polonium-211 $\left({ }^{211} \mathrm{Po}\right)$ & 7.61E-18 & $2.55 \mathrm{E}-19$ \\
\hline
\end{tabular}

Source: Eckerman and Ryman 1993 (DIRS 107684), Tables III.3 and III.7.

${ }^{\mathrm{a}}$ not included. 
Table 6-26. Dose Coefficients for Air Submersion and Water Immersion for Radionuclides of Interest

\begin{tabular}{|c|c|c|c|}
\hline \multirow[b]{2}{*}{ Primary Radionuclide } & \multirow[b]{2}{*}{$\begin{array}{l}\text { Short-lived Decay } \\
\text { Product }\end{array}$} & \multicolumn{2}{|c|}{ Dose Coefficient } \\
\hline & & $\begin{array}{l}\text { Air Submersion } \\
\text { Sv/s per } \mathrm{Bq} / \mathrm{m}^{3}\end{array}$ & $\begin{array}{c}\text { Water Immersion } \\
\text { Sv/s per } \mathrm{Bq} / \mathrm{m}^{3}\end{array}$ \\
\hline Carbon-14 $\left({ }^{14} \mathrm{C}\right)$ & & $2.24 \mathrm{E}-19$ & $4.39 \mathrm{E}-22$ \\
\hline Chlorine-36 $\left({ }^{36} \mathrm{Cl}\right)$ & & $2.23 \mathrm{E}-17$ & $4.48 \mathrm{E}-20$ \\
\hline Selenium-79 $\left({ }^{79} \mathrm{Se}\right)$ & & 3.03E-19 & 5.93E-22 \\
\hline \multirow[t]{2}{*}{ Strontium-90 $\left({ }^{90} \mathrm{Sr}\right)$} & & $7.53 \mathrm{E}-18$ & $1.46 \mathrm{E}-20$ \\
\hline & Yttrium-90 $\left({ }^{90} \mathrm{Y}\right)$ & $1.90 \mathrm{E}-16$ & 3.63E-19 \\
\hline Technetium-99 $\left({ }^{99} \mathrm{Tc}\right)$ & & $1.62 \mathrm{E}-18$ & $3.14 \mathrm{E}-21$ \\
\hline \multirow[t]{3}{*}{ Tin-126 ( $\left.{ }^{126} \mathrm{Sn}\right)$} & & $2.11 \mathrm{E}-15$ & $4.76 \mathrm{E}-18$ \\
\hline & Antimony-126m ( $\left.{ }^{126 m} \mathrm{Sb}\right)$ & $7.50 \mathrm{E}-14$ & $1.63 \mathrm{E}-16$ \\
\hline & Antimony-126 $\left({ }^{126} \mathrm{Sb}\right)$ & 1.37E-13 & 2.99E-16 \\
\hline lodine-129 $\left({ }^{129} \mathrm{I}\right)$ & & $3.80 E-16$ & 8.91E-19 \\
\hline Cesium-135 $\left({ }^{135} \mathrm{Cs}\right)$ & & $5.65 E-19$ & $1.10 \mathrm{E}-21$ \\
\hline \multirow[t]{2}{*}{ Cesium-137 $\left({ }^{137} \mathrm{Cs}\right)$} & & $7.74 \mathrm{E}-18$ & $1.49 \mathrm{E}-20$ \\
\hline & Barium-137m $\left({ }^{137 \mathrm{~m}} \mathrm{Ba}\right)$ & $2.88 \mathrm{E}-14$ & $6.26 \mathrm{E}-17$ \\
\hline \multicolumn{4}{|c|}{ Thorium Series $(4 n)$} \\
\hline Plutonium-240 $\left({ }^{240} \mathrm{Pu}\right)$ & & $4.75 \mathrm{E}-18$ & $1.11 \mathrm{E}-20$ \\
\hline Uranium-236 $\left({ }^{236} \mathrm{U}\right)$ & & $5.01 \mathrm{E}-18$ & 1.16E-20 \\
\hline Thorium-232 $\left({ }^{232} \mathrm{Th}\right)$ & & $8.72 \mathrm{E}-18$ & $1.99 \mathrm{E}-20$ \\
\hline \multirow[t]{2}{*}{ Radium-228 $\left({ }^{228} \mathrm{Ra}\right)$} & & $0.00 \mathrm{E}+00$ & $0.00 \mathrm{E}+00$ \\
\hline & Actinium-228 $\left({ }^{228} \mathrm{Ac}\right)$ & $4.78 \mathrm{E}-14$ & $1.04 \mathrm{E}-16$ \\
\hline Uranium-232 $\left({ }^{232} U\right)$ & & $1.42 \mathrm{E}-17$ & $3.22 \mathrm{E}-20$ \\
\hline \multirow[t]{8}{*}{ Thorium-228 $\left({ }^{228} \mathrm{Th}\right)$} & & $9.20 \mathrm{E}-17$ & $2.05 E-19$ \\
\hline & Radium-224 $\left({ }^{224} \mathrm{Ra}\right)$ & $4.71 E-16$ & $1.03 E-18$ \\
\hline & Radon-220 ( $\left.{ }^{220} \mathrm{Rn}\right)$ & $1.85 \mathrm{E}-17$ & 4.03E-20 \\
\hline & Polonium-216 $\left({ }^{216} \mathrm{Po}\right)$ & $8.29 E-19$ & $1.80 \mathrm{E}-21$ \\
\hline & Lead-212 $\left({ }^{212} \mathrm{~Pb}\right)$ & $6.87 \mathrm{E}-15$ & $1.52 \mathrm{E}-17$ \\
\hline & Bismuth-212 ( $\left({ }^{212} \mathrm{Bi}\right)$ & $9.24 \mathrm{E}-15$ & $2.00 \mathrm{E}-17$ \\
\hline & Polonium-212 ( $\left({ }^{212} \mathrm{Po}\right)$ & $0.00 \mathrm{E}+00$ & $0.00 \mathrm{E}+00$ \\
\hline & Thallium-208 ( $\left.{ }^{208} \mathrm{TI}\right)$ & $1.77 \mathrm{E}-13$ & $3.84 \mathrm{E}-16$ \\
\hline \multicolumn{4}{|c|}{ Neptunium Series $(4 n+1)$} \\
\hline Americium-241 ( $\left({ }^{241} \mathrm{Am}\right)$ & & $8.18 \mathrm{E}-16$ & $1.88 \mathrm{E}-18$ \\
\hline \multirow[t]{2}{*}{ Neptunium-237 $\left({ }^{237} \mathrm{~Np}\right)$} & & $1.03 E-15$ & $2.32 \mathrm{E}-18$ \\
\hline & Protactinium-233 $\left({ }^{233} \mathrm{~Pa}\right)$ & 9.35E-15 & $2.05 \mathrm{E}-17$ \\
\hline Uranium-233 $\left({ }^{233} \mathrm{U}\right)$ & & 1.63E-17 & 3.64E-20 \\
\hline \multirow[t]{9}{*}{ Thorium-229 $\left({ }^{229} \mathrm{Th}\right)$} & & 3.83E-15 & $8.56 \mathrm{E}-18$ \\
\hline & Radium-225 $\left({ }^{225} \mathrm{Ra}\right)$ & $2.79 \mathrm{E}-16$ & $6.49 \mathrm{E}-19$ \\
\hline & Actinium-225 $\left({ }^{225} \mathrm{Ac}\right)$ & $7.21 \mathrm{E}-16$ & $1.61 \mathrm{E}-18$ \\
\hline & Francium-221 $\left({ }^{221} \mathrm{Fr}\right)$ & 1.46E-15 & $3.22 \mathrm{E}-18$ \\
\hline & Astatine-217 $\left({ }^{217} \mathrm{At}\right)$ & 1.48E-17 & $3.22 \mathrm{E}-20$ \\
\hline & Bismuth-213 $\left({ }^{213} \mathrm{Bi}\right)$ & $6.39 \mathrm{E}-15$ & $1.39 \mathrm{E}-17$ \\
\hline & Polonium-213 $\left({ }^{213} \mathrm{Po}\right)$ & $0.00 \mathrm{E}+00$ & $0.00 \mathrm{E}+00$ \\
\hline & Thallium-209 ( $\left.{ }^{209} \mathrm{TI}\right)$ & $1.02 \mathrm{E}-13$ & $2.22 \mathrm{E}-16$ \\
\hline & Lead-209 $\left({ }^{209} \mathrm{~Pb}\right)$ & $8.12 \mathrm{E}-18$ & $1.57 \mathrm{E}-20$ \\
\hline
\end{tabular}


Characteristics of the Receptor for the Biosphere Model

Table 6-26. Dose Coefficients for Air Submersion and Water Immersion for Radionuclides of Interest (Continued)

\begin{tabular}{|c|c|c|c|}
\hline \multirow[b]{2}{*}{ Primary Radionuclide } & \multirow[b]{2}{*}{$\begin{array}{l}\text { Short-lived Decay } \\
\text { Product }\end{array}$} & \multicolumn{2}{|c|}{ Dose Coefficient } \\
\hline & & $\begin{array}{l}\text { Air Submersion } \\
\text { Sv/s per } \mathrm{Bq} / \mathrm{m}^{3}\end{array}$ & $\begin{array}{l}\text { Water Immersion } \\
\text { Svls per } \mathrm{Bq} / \mathrm{m}^{3}\end{array}$ \\
\hline \multicolumn{4}{|c|}{ Uranium Series $(4 n+2)$} \\
\hline Plutonium-242 $\left({ }^{242} \mathrm{Pu}\right)$ & & $4.01 \mathrm{E}-18$ & $9.35 \mathrm{E}-21$ \\
\hline \multirow[t]{4}{*}{ Uranium-238 $\left({ }^{238} \mathrm{U}\right)$} & & $3.41 \mathrm{E}-18$ & $7.95 \mathrm{E}-21$ \\
\hline & Thorium-234 $\left({ }^{234} \mathrm{Th}\right)$ & $3.38 \mathrm{E}-16$ & 7.64E-19 \\
\hline & Protactinium- $234 \mathrm{~m}\left({ }^{234 \mathrm{~m}} \mathrm{~Pa}\right)$ & $7.19 \mathrm{E}-16$ & $1.52 \mathrm{E}-18$ \\
\hline & Protactinium-234 $\left({ }^{234} \mathrm{~Pa}\right)$ & $9.34 \mathrm{E}-14$ & $2.03 E-16$ \\
\hline Plutonium-238 $\left({ }^{238} \mathrm{Pu}\right)$ & & $4.88 \mathrm{E}-18$ & $1.14 \mathrm{E}-20$ \\
\hline Uranium-234 $\left({ }^{234} \mathrm{U}\right)$ & & $7.63 \mathrm{E}-18$ & $1.75 \mathrm{E}-20$ \\
\hline Thorium-230 $\left({ }^{230} \mathrm{Th}\right)$ & & 1.74E-17 & $3.94 \mathrm{E}-20$ \\
\hline \multirow[t]{8}{*}{ Radium-226 $\left({ }^{226} \mathrm{Ra}\right)$} & & $3.15 E-16$ & $6.95 \mathrm{E}-19$ \\
\hline & Radon-222 $\left({ }^{222} \mathrm{Rn}\right)$ & $1.91 \mathrm{E}-17$ & $4.16 \mathrm{E}-20$ \\
\hline & Polonium-218 $\left({ }^{218} \mathrm{Po}\right)$ & $4.48 \mathrm{E}-19$ & $9.71 \mathrm{E}-22$ \\
\hline & Lead-214 $\left({ }^{214} \mathrm{~Pb}\right)$ & $1.18 \mathrm{E}-14$ & $2.59 \mathrm{E}-17$ \\
\hline & Astatine-218 $\left({ }^{218} \mathrm{At}\right)$ & $1.19 \mathrm{E}-16$ & $2.75 \mathrm{E}-19$ \\
\hline & Bismuth-214 $\left({ }^{214} \mathrm{Bi}\right)$ & $7.65 \mathrm{E}-14$ & $1.66 \mathrm{E}-16$ \\
\hline & Polonium-214 ( $\left({ }^{214} \mathrm{Po}\right)$ & $4.08 \mathrm{E}-18$ & $8.85 \mathrm{E}-21$ \\
\hline & Thallium-210 $\left({ }^{210} \mathrm{Tl}\right)$ & - & - \\
\hline \multirow[t]{3}{*}{ Lead-210 $\left({ }^{210} \mathrm{~Pb}\right)$} & & $5.64 \mathrm{E}-17$ & $1.31 \mathrm{E}-19$ \\
\hline & Bismuth-210 $\left({ }^{210} \mathrm{Bi}\right)$ & $3.29 \mathrm{E}-17$ & $6.33 \mathrm{E}-20$ \\
\hline & Polonium-210 $\left({ }^{210} \mathrm{Po}\right)$ & $4.16 \mathrm{E}-19$ & 9.03E-22 \\
\hline \multicolumn{4}{|c|}{ Actinium Series $(4 n+3)$} \\
\hline \multirow[t]{2}{*}{ Americium-243 $\left({ }^{243} \mathrm{Am}\right)$} & & $2.18 \mathrm{E}-15$ & 4.94E-18 \\
\hline & Neptunium-239 $\left({ }^{239} \mathrm{~Np}\right)$ & 7.69E-15 & $1.70 \mathrm{E}-17$ \\
\hline Plutonium-239 $\left({ }^{239} \mathrm{Pu}\right)$ & & $4.24 \mathrm{E}-18$ & $9.60 \mathrm{E}-21$ \\
\hline \multirow[t]{2}{*}{ Uranium-235 $\left({ }^{235} \mathrm{U}\right)$} & & $7.20 \mathrm{E}-15$ & 1.59E-17 \\
\hline & Thorium-231 $\left({ }^{231} \mathrm{Th}\right)$ & $5.22 \mathrm{E}-16$ & $1.18 \mathrm{E}-18$ \\
\hline Protactinium-231 $\left({ }^{231} \mathrm{~Pa}\right)$ & & $1.72 \mathrm{E}-15$ & 3.78E-18 \\
\hline \multirow[t]{10}{*}{ Actinium-227 $\left({ }^{227} \mathrm{Ac}\right)$} & & $5.82 \mathrm{E}-18$ & $1.30 \mathrm{E}-20$ \\
\hline & Thorium-227 (227 Th) & $4.88 \mathrm{E}-15$ & 1.07E-17 \\
\hline & Francium-223 $\left({ }^{223} \mathrm{Fr}\right)$ & $2.29 \mathrm{E}-15$ & $5.11 \mathrm{E}-18$ \\
\hline & Radium-223 $\left({ }^{223} \mathrm{Ra}\right)$ & $6.09 \mathrm{E}-15$ & 1.35E-17 \\
\hline & Radon-219 ( $\left.{ }^{219} \mathrm{Rn}\right)$ & $2.68 \mathrm{E}-15$ & $5.85 \mathrm{E}-18$ \\
\hline & Polonium-215 $\left({ }^{215} \mathrm{Po}\right)$ & $8.43 E-18$ & $1.84 \mathrm{E}-20$ \\
\hline & Lead-211 $\left({ }^{211} \mathrm{~Pb}\right)$ & $2.49 \mathrm{E}-15$ & $5.41 \mathrm{E}-18$ \\
\hline & Bismuth-211 $\left({ }^{211} \mathrm{Bi}\right)$ & $2.22 \mathrm{E}-15$ & $4.85 \mathrm{E}-18$ \\
\hline & Thallium-207 $\left({ }^{207} \mathrm{Tl}\right)$ & $1.62 \mathrm{E}-16$ & 3.38E-19 \\
\hline & Polonium-211 ( $\left.{ }^{211} \mathrm{Po}\right)$ & $3.81 \mathrm{E}-16$ & 8.27E-19 \\
\hline
\end{tabular}

Source: Eckerman and Ryman 1993 (DIRS 107684), Tables III.1 and III.2. 


\subsubsection{Radon Doses}

The DCF for inhalation of ${ }^{222} \mathrm{Rn}$ decay products was calculated based on the data from FGR No. 11 (Eckerman et al. 1988 [DIRS 101069] and ICRP 1981 [DIRS 163051]). The function of the DCF for radon, $D C F_{\text {inh,Rn-222,n }}$ in the biosphere model is to convert the exposure to radon decay products to dose (CEDE) for a unit $\left(1 \mathrm{~Bq} / \mathrm{m}^{3}\right)$ radon gas activity concentration in air and for a unit breathing rate $\left(1 \mathrm{~m}^{3} / \mathrm{hr}\right)$ (BSC 2004 [DIRS 169460], Section 6.4.8.4). This DCF for inhalation of ${ }^{222} \mathrm{Rn}$ decay products, can be derived based on the following:

- The potential alpha energy concentration (PAEC)-to-dose conversion factor for ${ }^{222} \mathrm{Rn}$ decay products is $0.010 \mathrm{~Sv}$ (1 rem) per working level month (ICRP 1981 [DIRS 163051], p. 15)

- One working level month (WLM) corresponds to an exposure to radon decay products whose PAEC is equal to 1 working level (WL) for a period of 1 working month (approximately 170 working hours) (10 CFR 20.1003 [DIRS 104787]).

- The PAEC of $1 \mathrm{WL}$ corresponds to any combination of short-lived radon decay products in one liter of air that will result in the ultimate emission of $1.3 \times 10^{5} \mathrm{MeV}$ of alpha energy (10 CFR 20.1003 [DIRS 104787]), which is approximately the alpha energy released from the decay of the short-lived decay products in equilibrium with $100 \mathrm{pCi}$ of ${ }^{222} \mathrm{Rn}$ (ICRP 1981 [DIRS 163051], pp. 18-19).

- The conversion factor of (1 rem)/(1 WLM) was developed for workers whose breathing rate is equal to $1.2 \mathrm{~m}^{3} / \mathrm{hr}$ (ICRP 1981 [DIRS 163051], pp. 7 and 15, Eckerman et al. 1988 [DIRS 101069], p. 10). Because the DCF for inhalation of ${ }^{222} \mathrm{Rn}$ applies to a unit breathing rate, an additional correction factor of $\frac{1}{1.2 \mathrm{~m}^{3} / \mathrm{h}}$ is used.

The DCF for inhalation of ${ }^{222} \mathrm{Rn}$ can thus be derived as follows:

$$
\begin{aligned}
D C F_{i n h, R n-222, n} & =\frac{1 \mathrm{rem}}{1 \mathrm{WLM}} \frac{1 \mathrm{WLM}}{170 \mathrm{WL} h} \frac{1 \mathrm{WL}}{100 \mathrm{pCi} / \mathrm{L}} \frac{1 \mathrm{pCi} / \mathrm{L}}{37 \mathrm{~Bq} / \mathrm{m}^{3}} \frac{0.01 \mathrm{~Sv}}{1 \mathrm{rem}} \frac{1}{1.2 \mathrm{~m}^{3} / \mathrm{h}} \times E F_{R n-222, n}= \\
& =1.33 \times 10^{-8} E F_{R n-222, n} \frac{\mathrm{Sv}}{\mathrm{Bq}}=D C F_{i n h, R n-222} E F_{R n-222, n}
\end{aligned}
$$

where

$$
\begin{aligned}
E F_{R n-22, n}= & \begin{array}{l}
\text { equilibrium factor for }{ }^{222} \mathrm{Rn} \text { decay products for the environment } n \\
\text { (dimensionless) }
\end{array}= \\
D C F_{\text {inh, } R n-222=} & \begin{array}{l}
\text { DCF for inhalation of }{ }^{222} \mathrm{Rn} \text { decay products in equilibrium with radon } \\
\text { gas }\left(1.33 \times 10^{-8} \mathrm{~Sv} / \mathrm{Bq}\right. \text {, rounded up to three significant digits) }
\end{array}
\end{aligned}
$$

The equilibrium factor, $E F_{R n-222}$, permits estimation of PAEC from the measurement of radon gas (here ${ }^{222} \mathrm{Rn}$ ). It is defined as the ratio of the actual PAEC to the PAEC that would prevail if all the decay products in the $\left({ }^{222} \mathrm{Rn}\right)$ series were in equilibrium with the parent radon. The 
equilibrium factor depends on the environment and is typically higher for the outdoor environment than indoor (UNSCEAR 2000 [DIRS 158644], pp. 103-104).

\subsubsection{Dependence of Inhalation Dose Conversion Factors on Particle Sizes}

To estimate inhalation exposure to airborne particulates one needs to know the particle size distribution because the DCFs vary with the particle size. It is generally considered that the particles that may become resuspended are associated with the aerodynamic diameters of less than $100 \mu \mathrm{m}$ (Anspaugh et al. 1975 [DIRS 151548], p. 572). The smallest of these particles (less than about $10 \mu \mathrm{m}$ ) may be suspended for a considerable amount of time (Nicholson 1988 [DIRS 160116], p. 2642).

\subsubsection{Particle Size Distribution of Environmental Aerosols}

The size distribution of resuspended particles depends not only on the characteristic of the site but also on the activities that result in generation of airborne particulates. Shinn (1992 [DIRS 160115], p. 1190) indicates that average median aerodynamic diameter of particles produced by resuspension of material deposited on the ground is in the range between 2 and $6 \mu \mathrm{m}$. Dorrian (1997 [DIRS 159476], pp. 117, 129) concluded that the median value of AMAD for resuspended aerosols was $6 \mu \mathrm{m}$. The measurements by Shinn (1992 [DIRS 160115]) include experiments performed at the Nevada Test Site. A coarse component (greater than about $2 \mu \mathrm{m}$ ), with median diameter of about $15 \mu \mathrm{m}$ is sometimes also found when the soil is disturbed or when very strong winds are present (NCRP 1999 [DIRS 155894], p. 67). This coarse component should be considered transient because the gravitational settling velocities of the coarse particles are greater than the suspension velocities and their residence times in the atmosphere are short (NCRP 1999 [DIRS 155894], p. 67). In general, the ratio of total suspended particulates to the $\mathrm{PM}_{10}$ fraction (particulates with the median aerodynamic diameter less than $10 \mu \mathrm{m}$ ) increases under disturbed conditions (NCRP 1999 [DIRS 155894], p. 67). The generic recommended particle size distribution is lognormal with a median diameter in the range of 2 to $6 \mu \mathrm{m}$ and a geometric standard deviation of about five (NCRP 1999 [DIRS 155894], p. 68). Such distribution applies to the long-term, average conditions. The particle size distribution of airborne activity may be different from the distribution of the suspended soil dust, particularly if the radioactive particles are preferentially bound to a specific size range of the soil particles. This may be the case for the volcanic ash exposure scenario, as described later in this section.

Short-term particle size distributions may include a larger contribution from the coarse component, compared to the average conditions, especially during or immediately following a dust generating activity. For example, agricultural activities may involve generation of high levels of dust. In one study conducted in arid agricultural regions in California, it was observed that dust particles were relatively large and that the largest proportion of the dust belonged to the extrathoracic fraction (>10 $>$ m) (Nieuwenhuijsen et al. 1998 [DIRS 150855], p. 36). The average mass median aerodynamic diameter measured during various agricultural operations was $49 \mu \mathrm{m}$ (Nieuwenhuijsen et al. 1998 [DIRS 150855], p. 36). The proportion of small particles (less than $10 \mu \mathrm{m}$ ) for most activities was less than 10 percent of the total mass and generally was lower for dustier activities. Another study of natural aerosols in the arid southwestern United States concluded that near-surface aerosol is comprised to two modes: a wind-derived 
supermicron component which is likely soil-derived and local in origin and a submicron component that is likely a product of long-range atmospheric transport (Pinnick et al. 1993 [DIRS 160312], pp. 2651 and 2664). The supermicron component dominates the total aerosol mass while submicron mode contributes little to the aerosol mass. During the disturbed conditions, such as dust storm, there is an increase in concentration of supermicron aerosols (coarse mode with particle sizes up to $100 \mu \mathrm{m}$ ) that consists almost exclusively of particles of the parent soil. The submicron aerosol concentration was nearly unaffected by the disturbed conditions (Pinnick et al. 1993 [DIRS 160312], p. 2659). Similar findings resulted from the study by Whitby as reported in EPA (1996 [DIRS 160121], p. 3-161, Figure 3-22), who concluded that the concentration of particles smaller than $2.5 \mu \mathrm{m}$ in diameter was not affected by the strong winds. The review of the available information on airborne particulates, with emphasis on the coarse mode, concluded that the coarse model could be reasonably well described by a lognormal distribution with a mass median aerodynamic diameter of 15 to $25 \mu \mathrm{m}$ and a geometric standard deviation of approximately two (EPA 1996 [DIRS 160121], p. 3-160). Thus for a freshly generated coarse model aerosol, only about 1 percent of the mass would be less than $2.5 \mu \mathrm{m}$ and only about 0.1 percent would be less than $1.0 \mu \mathrm{m}$ in diameter (EPA 1996 [DIRS 160121], pp. 3-160 to 3-161). Based on the reviewed literature (EPA 1996 [DIRS 160121], Sections 3.7.5 - 3.7.8; Nieuwenhuijsen et al. 1998 [DIRS 150855]; Pinnick et al. 1993 [DIRS 160312]), the airborne particles originating from the local soils range in size from about $0.1 \mu \mathrm{m}$ to about $100 \mu \mathrm{m}$.

Particle size distribution for the indoor environment differs from that characteristic of the outdoor environment. Under typical conditions, aerosols in the coarse mode $(>2 \mu \mathrm{m})$ are only likely to give rise to exposures to people who are outdoors and close to the site of contamination (Dorrian 1997 [DIRS 159476], p. 129-130). In the indoor environment, concentration of large particles is significantly depleted in comparison to the outdoor environment and particles larger than $5 \mu \mathrm{m}$ would be decreasingly likely to penetrate indoors (Dorrian 1997 [DIRS 159476], p. 130).

The volcanic ash exposure scenario involves generation of contaminated ash particles that can be transported in the atmosphere and subsequently deposited on the ground. Explosive eruptive styles of Quaternary volcanoes in the Yucca Mountain region include both strombolian and violent strombolian (BSC 2004 [DIRS 169980], Section 6.3.3.6.1). The distribution of the average size ash particles resulting from a volcanic eruption at Yucca Mountain is defined as logtriangular with a minimum of $0.01 \mathrm{~mm}(10 \mu \mathrm{m})$, a mode of $0.1 \mathrm{~mm}(100) \mu \mathrm{m}$, and a maximum of $1.0 \mathrm{~mm}(1,000 \mu \mathrm{m})$. The distribution of mean ash particle standard deviation is uniform from 1-3 phi units (BSC 2004 [DIRS 169980], Section 6.3.3.6.1 and Table 7-1) (phi units are defined as a negative logarithm in base 2 of the particle diameter in millimeters, BSC 2004 [DIRS 169980], Section 6.1.3.5). This distribution is consistent with the particle size distributions for the analogue volcanoes (Tolbachik and Cerro Negro) of the violent strombolian type (BSC 2004 [DIRS 169980], Section 6.3.3.6.1).

The distribution of the waste particle size has a minimum of $1 \mu \mathrm{m}$, the mode of $16 \mu \mathrm{m}$, and the maximum of $500 \mu \mathrm{m}$ (BSC 2004 [DIRS 170026], Section 6.5.2.16). Based on the particle size, only a small fraction of particles (the smallest predicted average ash sizes have a very low probability of occurrence) would be available for resuspension. 
During volcanic eruption intersecting the repository, the waste becomes incorporated into the ash with the incorporation ratio of 0.3 (BSC 2004 [DIRS 170026], Section 6.5.2.6). The incorporation ratio describes the ratio of ash/waste particle sizes that can be attached together. The waste mass is distributed among the ash mass based on relative particle sizes. Incorporation of waste particles requires ash particles of a certain size or larger. Thus, larger ash particles will carry a greater mass of radioactive waste particles than smaller ash particles (BSC 2004 [DIRS 170026], Section 6.5.2.6).

The model for atmospheric transport of contaminated volcanic ash (ASHPLUME) is appropriate for particles of mean diameter greater than 15-30 $\mu \mathrm{m}$ (Jarzemba et al. 1997 [DIRS 100987], p. 2-2). Although the model is useful for calculating the distribution of the majority of ash (typical mean diameter of ash particle after an eruption is generally much greater than $15 \mu \mathrm{m}$ ), it does not address well the particles in the respirable (less than $4 \mu \mathrm{m}$ ) and thoracic (less than $10 \mu \mathrm{m}$ ) size range, which are more important for the evaluation of inhalation doses. Therefore, the information from the analog volcano was used to estimate the airborne particle sizes for the evaluation of inhalation exposure of the receptor. The measurements performed at about $21 \mathrm{~km}$ from the Cerro Negro volcano indicate that only about 20 percent of the deposited ash particles by mass are in the inhalable particle size range (less than $100 \mu \mathrm{m}$ ) (Reamer and Williams 2000 [DIRS 154597], Attachment 17 of Appendix 4). Particles in this size range can become airborne either due to natural processes or as the result of the human surface disturbing activities.

The suspendibility of particles depends on their aerodynamic properties. Therefore it can be reasonably expected that the range of the aerodynamic diameters of the suspended ash particles will be similar to the range of suspended soil particles described above, although the mass particle size ranges may be different due to the differences in particle densities and shapes. The same range of particle sizes is also expected for the future climate considered within the applicability limits of the biosphere model.

\subsubsection{Dosimetric Considerations for Airborne Particulates}

From the human health perspective, particulates can be classified into inhalable, thoracic and respirable, according to their entrance and deposition in the various compartment of the respiratory system. Inhalable particles refer to those that enter the respiratory tract, including the head airways region (anterior and posterior nose, larynx, pharynx and mouth). Thoracic particles refer to particles that reach the lung airways and the gas-exchange region (bronchial, bronchiolar, and alveolar regions), and respirable particles are those that reach the gas-exchange region (alveolar region) (EPA 1996 [DIRS 160121], p. 3-11; ICRP 1994 [DIRS 153705], pp. 8-11). The term extrathoracic particles used later in this section refers to particles that do not reach the lung airways and the gas exchange region.

The most important parameter determining the particle's aerodynamic behavior and respiratory tract deposition is its aerodynamic equivalent diameter, which depends on particle density and shape (Dorrian 1997 [DIRS 159476], p. 117). The DCFs for inhalation of airborne contaminants depend on their aerodynamic diameter. To ensure consistent use, the inhalation DCFs are tabulated for particles with a given AMAD. AMAD is defined as the diameter of a unit-density sphere having the same terminal settling velocity in air as the aerosol particle whose activity is the median for the entire aerosol (Eckerman et al. 1988 [DIRS 101069], p. 219), i.e., 50 percent 
of an aerosol's activity is associated with particles whose aerodynamic equivalent diameter is greater than the AMAD. Respiratory tract deposition of radioactive aerosols is related to the AMAD of the particle size distribution and is relatively insensitive to the geometric standard deviation of the distribution.

The density of most of the environmental particles is greater than unity. Therefore such particles are aerodynamically equivalent to larger particles of unit density (aerodynamic diameter is directly proportional to the square root of the particle density) (EPA 1996 [DIRS 160121], p. 3-9).

The size distribution of resuspended soil particles may be described as lognormal bimodal with one mode at 2-5 $\mu \mathrm{m}$ and another mode at 30 to $60 \mu \mathrm{m}$ (EPA 1996 [DIRS 160121], p. 3-36) and the size range of the particles originating in local soil is typically between 0.1 and $100 \mu \mathrm{m}$ (see Section 6.5.5.1). The inhalation DCFs based on the ICRP-30 dosimetric methods are most commonly tabulated for particulates whose diameter is distributed lognormally with an AMAD of $1 \mu \mathrm{m}$ (ICRP 1979 [DIRS 110386], Eckerman et al. 1988 [DIRS 101069]). Using the respiratory tract model of ICRP Publication 30 (ICRP 1979 [DIRS 110386], pp. 23-29) the DCFs for $1-\mu \mathrm{m}$ particles can be converted to DCFs for other particle sizes, as described below.

The conversion method is based on the formula (ICRP 1979 [DIRS 110386], Equation 5.8) that calculates the committed dose equivalent in an organ $T$ for particles of a given AMAD, $H_{T}$ $(A M A D)$, as a fraction of the committed dose equivalent in this organ for 1- $\mu$ m particles, $H_{T}$ $(1 \mu \mathrm{m})$ :

$$
\frac{H_{T}(A M A D)}{H_{T}(1 \mu m)}=f_{N-P} \frac{D_{N-P}(A M A D)}{D_{N-P}(1 \mu m)}+f_{T-B} \frac{D_{T-B}(A M A D)}{D_{T-B}(1 \mu m)}+f_{P} \frac{D_{P}(A M A D)}{D_{P}(1 \mu m)}
$$

where

$$
\begin{aligned}
& f_{N-P}=\text { fraction of the committed dose equivalent in the reference tissue } \\
& D_{N-P}(A M A D)=\text { deposition probability in the } N-P \text { region of the respiratory tract for a } \\
& D_{N-P}(1 \mu \mathrm{m})=\text { deposition probability in the } N-P \text { region of the respiratory tract for a } \\
& \text { given AMAD (from ICRP } 1979 \text { [DIRS 110386], Figure 5.1) } \\
& f_{T-B} \quad=\text { fraction of the committed dose equivalent in the reference tissue } \\
& D_{T-B}(A M A D)=\text { deposition probability in the } T-B \text { region of the respiratory tract for a } \\
& \text { given AMAD (from ICRP } 1979 \text { [DIRS 110386], Figure 5.1) } \\
& D_{T-B}(1 \mu \mathrm{m})=\text { deposition probability in the } T-B \text { region of the respiratory tract for a } \\
& \mu \mathrm{m} \text { AMAD (from ICRP } 1979 \text { [DIRS 110386], Figure 5.1) } \\
& f_{P} \quad=\text { fraction of the committed dose equivalent in the reference tissue } \\
& \text { resulting from deposition in the pulmonary, } P \text {, region of the } \\
& \text { respiratory tract }
\end{aligned}
$$




$$
\begin{aligned}
D_{P}(A M A D)= & \text { deposition probability in the } P \text { region of the respiratory tract for a } \mu \mathrm{m} \\
& \text { AMAD (from ICRP 1979 [DIRS 110386], Figure 5.1) } \\
D_{P}(1 \mu \mathrm{m})= & \text { deposition probability in the } P \text { region of the respiratory tract for a } \mu \mathrm{m} \\
& \text { AMAD (from ICRP 1979 [DIRS 110386], Figure 5.1). }
\end{aligned}
$$

The respiratory tract model of ICRP Publication 30 is intended for use with aerosol distributions with AMAD between 0.2 and $10 \mu \mathrm{m}$ and with geometric standard deviations of less than 4.5. Provisional estimates of deposition further extending the size range from $0.1 \mu \mathrm{m}$ to $20 \mu \mathrm{m}$ were provided. For distributions with an AMAD of greater than $20 \mu \mathrm{m}$ it is recommended that the complete deposition in the naso-pharyngeal region be assumed (ICRP 1979 [DIRS 110386], p. 24). The relationship between the values of $D_{N-P}, D_{T-B}$, and $D_{P}$, representing the fractions of the inhaled particles that are estimated to deposit in the three regions of the respiratory tract, and the aerodynamic sizes of the particles were developed for an adult male involved in light work.

The weighted committed dose equivalent in an organ per intake of unit activity for particles (here $1 \mathrm{~Bq}$ ) of a given $\mathrm{AMAD}, w_{T} H_{T, 1}(A M A D)$, can then be calculated by multiplying the ratio obtained using Equation 6.5-1 by the weighted committed dose equivalent in this organ per intake of unit activity for $1 \mu \mathrm{m}$ particles.

$$
w_{T} H_{T, 1}(A M A D)=\frac{H_{T}(A M A D)}{H_{T}(1 \mu m)} w_{T} H_{T, 1}(1 \mu m)
$$

where

$$
w_{T} \quad=\quad \text { organ or tissue weighting factor }
$$

The weighted committed dose equivalent for various organs per intake of unit activity for 1- $\mu$ m particles and the fractions of the committed dose equivalent in these organs or tissues resulting from deposition in various parts of the respiratory tract can be found in Supplements to Parts 1, 2 and 3 of ICRP Publication 30 (ICRP 1978 [DIRS 101076], pp. 84-85, 192-193, 231-232, 236-237, 289-290, 318, 322-323, 333-334, 356-357, 362, 364-365, 371, 378, 410-411, 414-415, 418-419, 424-425, 456, 466-467; ICRP 1981 [DIRS 153056], pp. 19, 195, 660-661, 739; ICRP 1982 [DIRS 153057], pp. 790, 827; ICRP 1982 [DIRS 163147], pp. 158-159). The committed EDE can then be calculated by summing up the organ-weighted committed dose equivalents. Their sum represents the effective (weighted) dose equivalent for a given AMAD per intake of unit activity by inhalation. This quantity can be compared to the corresponding DCF for $1-\mu \mathrm{m}$ particles by producing a following ratio of these two quantities:

$$
\text { Ratio }=\frac{\sum_{T} w_{T} H_{T, 1}(A M A D)}{\sum_{T} w_{T} H_{T, 1}(1 \mu m)}
$$

The ratio identified in Equation 6.5-3 is a measure of how closely the DCFs for 1- $\mu$ m particles represent DCFs for other particle sizes, with the value of 1 meaning that the respective DCFs are 
equal. Such ratios were calculated for a range of particle sizes corresponding to the expected range of particle sizes for resuspended contaminated soil, i.e., from 0.1 to $100 \mu \mathrm{m}$. As noted previously, the model is intended for use with aerosol distributions with AMAD between 0.2 and $10 \mu \mathrm{m}$ and the values beyond this range are provisional. The results of comparison are summarized in Table 6-27. The same information is also presented graphically in Figure 6-13. The Excel spreadsheet calculations are shown in Appendix B. The Excel file (file name Inhalation of large particles.xls) is provided in Appendix C.

Table 6-27. Comparison of Inhalation Dose Conversion Factors Between 1- $\mu \mathrm{m}$ Particles and Other Size Particles

\begin{tabular}{|c|c|c|c|c|c|c|c|c|c|}
\hline \multirow[b]{2}{*}{ Radionuclide } & \multicolumn{9}{|c|}{ DCF Ratio (DCF for a Given Size Particles to DCF for 1- $\mu \mathrm{m}$ Particles) ${ }^{\mathrm{a}}$} \\
\hline & $0.1 \mu \mathrm{m}$ & $0.2 \mu \mathrm{m}$ & $0.5 \mu \mathrm{m}$ & $1 \mu \mathrm{m}$ & $2 \mu \mathrm{m}$ & $5 \mu \mathrm{m}$ & $10 \mu \mathrm{m}$ & $20 \mu \mathrm{m}$ & $100 \mu \mathrm{m}$ \\
\hline Chlorine-36 & 2.4 & 2.0 & 1.4 & 1.0 & 0.7 & 0.4 & 0.2 & 0.1 & 0.0 \\
\hline Selenium-79 & 1.9 & 1.5 & 1.2 & 1.0 & 0.9 & 0.9 & 0.9 & 0.9 & 0.8 \\
\hline Strontium-90 & 1.7 & 1.2 & 1.0 & 1.0 & 1.1 & 1.2 & 1.3 & 1.3 & 1.2 \\
\hline Technetium-99 & 2.4 & 2.0 & 1.4 & 1.0 & 0.7 & 0.4 & 0.2 & 0.1 & 0.0 \\
\hline Tin-126 & 2.3 & 1.9 & 1.4 & 1.0 & 0.7 & 0.5 & 0.3 & 0.2 & 0.1 \\
\hline lodine-129 & 1.4 & 1.0 & 1.0 & 1.0 & 1.2 & 1.4 & 1.6 & 1.6 & 1.6 \\
\hline Cesium-135 & 1.5 & 1.0 & 1.0 & 1.0 & 1.1 & 1.4 & 1.6 & 1.5 & 1.5 \\
\hline Cesium-137 & 1.5 & 1.0 & 1.0 & 1.0 & 1.1 & 1.4 & 1.6 & 1.6 & 1.5 \\
\hline Lead-210 & 1.7 & 1.2 & 1.0 & 1.0 & 1.1 & 1.2 & 1.3 & 1.2 & 1.2 \\
\hline Radium-226 & 2.3 & 1.9 & 1.4 & 1.0 & 0.7 & 0.5 & 0.3 & 0.2 & 0.1 \\
\hline Actinium-227 & 1.8 & 1.3 & 1.1 & 1.0 & 1.0 & 1.1 & 1.2 & 1.1 & 1.1 \\
\hline Thorium-229 & 1.9 & 1.2 & 1.1 & 1.0 & 1.0 & 1.1 & 1.1 & 0.9 & 0.8 \\
\hline Thorium-230 & 1.9 & 1.2 & 1.1 & 1.0 & 1.0 & 1.1 & 1.1 & 0.9 & 0.8 \\
\hline Thorium-232 & 1.9 & 1.2 & 1.1 & 1.0 & 1.0 & 1.1 & 1.1 & 0.9 & 0.8 \\
\hline Protactinium-231 & 1.9 & 1.2 & 1.1 & 1.0 & 1.0 & 1.1 & 1.1 & 0.9 & 0.8 \\
\hline Uranium-232 & 2.4 & 2.0 & 1.4 & 1.0 & 0.7 & 0.4 & 0.2 & 0.1 & 0.0 \\
\hline Uranium-233 & 2.4 & 2.0 & 1.4 & 1.0 & 0.7 & 0.4 & 0.2 & 0.1 & 0.0 \\
\hline Uranium-234 & 2.4 & 2.0 & 1.4 & 1.0 & 0.7 & 0.4 & 0.2 & 0.1 & 0.0 \\
\hline Uranium-236 & 2.4 & 2.0 & 1.4 & 1.0 & 0.7 & 0.4 & 0.2 & 0.1 & 0.0 \\
\hline Uranium-238 & 2.4 & 2.0 & 1.4 & 1.0 & 0.7 & 0.4 & 0.2 & 0.1 & 0.0 \\
\hline Neptunium-237 & 1.9 & 1.2 & 1.1 & 1.0 & 1.0 & 1.1 & 1.2 & 1.0 & 0.9 \\
\hline Plutonium-238 & 1.9 & 1.2 & 1.1 & 1.0 & 1.0 & 1.1 & 1.1 & 0.9 & 0.8 \\
\hline Plutonium-239 & 1.9 & 1.2 & 1.1 & 1.0 & 1.0 & 1.1 & 1.1 & 0.9 & 0.8 \\
\hline Plutonium-240 & 1.9 & 1.2 & 1.1 & 1.0 & 1.0 & 1.1 & 1.1 & 0.9 & 0.8 \\
\hline Plutonium-242 & 1.9 & 1.2 & 1.1 & 1.0 & 1.0 & 1.1 & 1.1 & 0.9 & 0.8 \\
\hline Americium-241 & 1.9 & 1.2 & 1.1 & 1.0 & 1.0 & 1.1 & 1.1 & 0.9 & 0.8 \\
\hline Americium-243 & 1.9 & 1.2 & 1.1 & 1.0 & 1.0 & 1.1 & 1.1 & 0.9 & 0.8 \\
\hline
\end{tabular}

a Calculated in Excel file Inhalation of large particles.xIs, explained in Appendix B, from Equations 6.5-1 to 6.5-3 using values from ICRP 1978 (DIRS 101076), pp. 84-85, 192-193, 231-232, 236-237, 289-290, 318, 322-323, 333-334, 356-357, 362, 364-365, 371, 378, 410-411, 414-415, 418-419, 424-425, 456, 466-467; ICRP 1981 (DIRS 153056), pp. 19, 195, 660-661, 739; ICRP 1982 (DIRS 153057), pp. 790, 827; ICRP 1982 (DIRS 163147), pp. 158-159. 


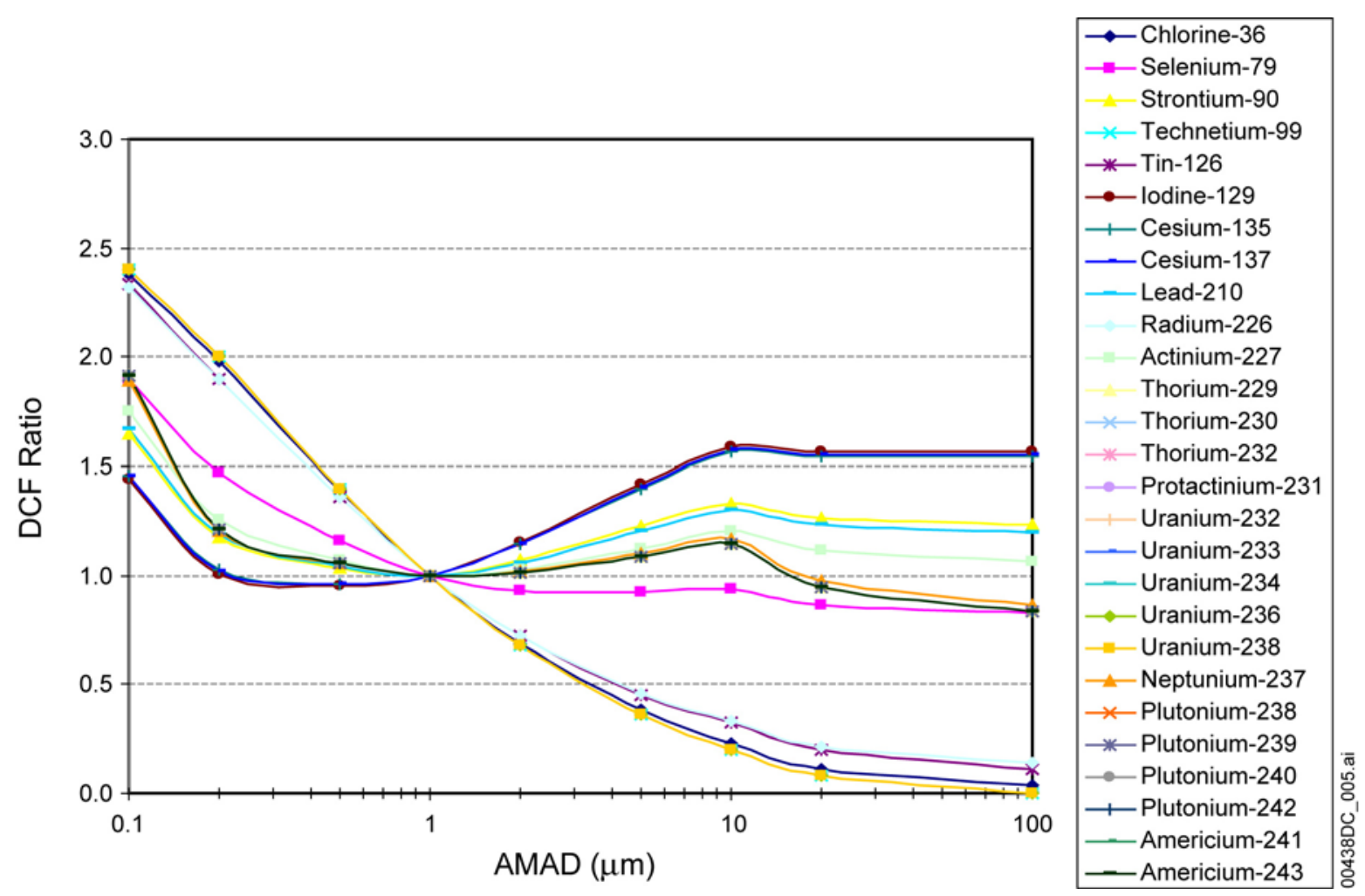

Source: Based on the values shown in Table 6-27.

Figure 6-13. The Ratio of Inhalation Dose Conversion Factors for Particulates of a Given AMAD to that of $1-\mu \mathrm{m}$ Particulates

To determine the expected range of the inhalation DCF ratios, a comparison was made for primary radionuclides except ${ }^{14} \mathrm{C}$, which is inhaled as a gas $\left(\mathrm{CO}_{2}\right)$. The decay products of the primary radionuclides were not included in this analysis because the majority of them are either isotopes of the elements already represented by the primary radionuclides (the DCF ratios for isotopes of the same element are the same, as shown in Table 6-27) or they are sufficiently short-lived such that their contribution is already accounted for in the DCF of the parent (DCF include contributions from decay products that are generated within the body).

The DCF ratios for $0.1-\mu \mathrm{m}$ to $100-\mu \mathrm{m}$ particles range from 0.0 to 2.4 . The DCFs are generally higher for the smallest particles. The radionuclides, such as isotopes of uranium, whose DCFs are the highest for small particles also have the lowest DCFs for large particles because of the whole or a large proportion of the dose originating in the lungs (large particles are deposited in the naso-pharyngial region and do not reach the lungs). The AMAD for the soil-derived airborne particulates for the long-term averages is expected to be in the 2-6 $\mu \mathrm{m}$ range. However, it is anticipated that the majority of the inhalation exposure to the RMEI will occur in the dusty environments associated with relatively large particles. Therefore, the AMADs larger than $1 \mu \mathrm{m}$ are more appropriate to represent particle size distribution in various environments addressed in the biosphere model. For such particles, the DCF ratios do not exceed 1.6. The contribution to the dose from inhalation of particulates is high for the heavy radionuclides, such as isotopes of neptunium, plutonium, and americium (BSC 2004 [DIRS 169674], Section 6.2.5; BSC 2004 [DIRS 167287], Section 6.2.5). Isotopes of these elements are also the highest contributors to 
the all-radionuclide dose for the igneous disruption scenario (DOE 2001 [DIRS 153849], Figure 4-194). For these radionuclides and AMADs between 0.5 and $100 \mu \mathrm{m}$ the DCF ratio is close to 1 and ranges from 0.8 to 1.2.The DCF ratios needs to be put into perspective considering uncertainties associated with the DCF values. The DCF uncertainties are not customarily included in radiological assessments. For instance, the internal dosimetry methods recommended for a performance assessment by the NRC (2000 [DIRS 157704], Section 3.3.7.3.1) are based on FGR No. 11 (Eckerman et al. 1988 [DIRS 101069]), which does not include consideration of uncertainty in the DCF values. However, the DCFs are subject to uncertainty. The estimated uncertainties in inhalation DCFs for selected radionuclides were tabulated by NCRP (NCRP 1999 [DIRS 155894], p. 83). For heavy radionuclides, such as ${ }^{210} \mathrm{~Pb}$, ${ }^{210} \mathrm{Po},{ }^{226} \mathrm{Ra},{ }^{230} \mathrm{Th},{ }^{234} \mathrm{U},{ }^{237} \mathrm{~Np},{ }^{239} \mathrm{Pu}$, and ${ }^{241} \mathrm{Am}$, the estimated uncertainty range is quantified as 5 for adult males and up to 10 for other population groups, while for ${ }^{90} \mathrm{Sr}$ and ${ }^{137} \mathrm{Cs}$, the uncertainty range is estimated at 3 and 2, respectively, for adult males and 5 for other groups (NCRP 1999 [DIRS 155894], p. 83). The uncertainty range can be interpreted as indicating that the DCF for some individuals may be as much as a given factor higher or lower than the dose factor recommended by ICRP. It also needs to be noted that these uncertainty estimates apply to the new ICRP respiratory tract model, which is considered more realistic than the older, ICRP-30-based model.

The new respiratory tract model was also used to analyze the appropriateness of the 1- $\mu \mathrm{m}$ AMAD DCFs recommended by the ICRP as a default for indoor or outdoor exposure of the general public (ICRP 1996 [DIRS 152446], p. 5). This recommendation is considered appropriate for estimating doses to members of the public when particle size distributions are unknown (Dorrian 1997 [DIRS 159476], p. 130). However, when the exposure is known to have resulted from inhalation of resuspended radioactive aerosols, the AMAD of $5 \mu \mathrm{m}$ appears to be more realistic for estimating the doses (Dorrian 1997 [DIRS 159476], p. 117).

As noted previously, the respiratory tract model of ICRP Publication 30 was intended for use with aerosol distributions with AMADs between 0.2 and $10 \mu \mathrm{m}$. The new respiratory tract models developed by NCRP (1997 [DIRS 160260]) and ICRP (1994 [DIRS 153705]) extended the range of particle sizes from 0.001 to $100 \mu \mathrm{m}$. For the exposure to airborne particulates under disturbed conditions, the majority of particulates are associated with large particles. For such particles $(>20 \mu \mathrm{m})$, the ICRP model recommends that the complete deposition in the naso-pharyngeal region be assumed (ICRP 1979 [DIRS 110386], p. 24). The NCRP model, on the other hand, predicts a reduced deposition for very large particles in the upper airways due to the lower inspirability of such particles (NCRP 1998 [DIRS 160160], p. 37). Inspirability (also called inhalability) is the probability that particles with a particular aerodynamic diameter are able to follow the air stream from outside air into the respiratory tract.

Considering the above, it was concluded that the application of DCFs for particles with AMAD of $1 \mu \mathrm{m}$ will not underestimate the doses from inhalation of resuspended material and that such DCFs are adequate for use in the biosphere model. 


\subsection{BUILDING SHIELDING FACTORS}

The shielding offered by the floors and walls of the house varies widely depending on the type of construction, height above ground, and other factors. Even for lightly constructed houses (i.e., buildings such as mobile homes with thin walls and floors), the exposure rate from the high-energy gamma emitters is reduced to about 0.4 of the outside value (NCRP 1999 [DIRS 155894], p. 52). The degree of reduction of indoor exposure relative to outdoor exposure is described by the building shielding factor, which is defined as ratio of dose indoors to dose outdoors. Shielding factors range from 0.001 to 0.5 (with higher values associated with buildings of light construction), with a mean of 0.2 (NCRP 1999 [DIRS 155894], p. 53). The shielding factors recommended by the NCRP for the use in screening models were calculated for a receptor population consisting of persons living in the most lightly constructed housing. Such shielding factors are appropriate for the Amargosa Valley population because 375 of 422 (88.9 percent) occupied housing units in the 2000 Census were mobile homes (Bureau of the Census 2002 [DIRS 159728], Tables H30 and H31). In addition, the 2000 Census data indicated that 91.3 percent of the total Amargosa Valley population (1043 of 1142 people) lived in mobile homes (Bureau of the Census 2002 [DIRS 159728], Table H33).

Four different shielding factor values were chosen for different radionuclides depending on the relative penetrability of their emissions (energy and type of radiation emitted) as follows (NCRP 1999 [DIRS 155894], p. 52). Relative penetrability was determined by comparing the dose coefficients for different geometries of the source and evaluating their differences with assumed radionuclide concentration profile in the soil. For radionuclides with highly penetrating radiations (gamma emitters of energy $>100 \mathrm{keV}$ ) a shielding factor of 0.4 was chosen. For low energy gamma (energy less than $100 \mathrm{keV}$ ) or high-energy beta (average energy > $100 \mathrm{keV}$ ) emitters, a shielding factor equal to 0.3 was chosen. For pure beta emitters with average energy less than $100 \mathrm{keV}$, and very low energy gamma emitters with energy less than $50 \mathrm{keV}$, a shielding factor of 0.2 was chosen. For low-energy $x$-ray emitters (energy less than $30 \mathrm{keV}$ ), the chosen value of shielding factor is 0.1 .

The default value of the shielding factor used in the RESRAD code is 0.7 (Yu et al. 2001 [DIRS 159465], p. A-8). RESRAD is the code designed to estimate radiation doses and risks from residual radioactive materials in environmental media, including soil (Yu et al. 2001 [DIRS 159465]). This value implies that the indoor levels of external radiation are only 30 percent lower than the outdoor levels. The RESRAD authors state that this value is likely to be conservative when applied to scenarios involving low to moderate energy gamma emitters or when applied to well-shielded buildings. The review of the values of shielding factor reported in NCRP (1999 [DIRS 155894], p. 53) indicates that the shielding factor values are lower than the value of 0.7 used in RESRAD. Therefore, the shielding factors recommended for the use in screening models are considered appropriate for the biosphere model for evaluation of indoor exposures at home and at work. The list of shielding factors for the primary radionuclides and their decay products is shown in Table 6-28. Shielding factor for ${ }^{14} \mathrm{C},{ }^{210} \mathrm{Tl},{ }^{212} \mathrm{Po},{ }^{213} \mathrm{Po},{ }^{222} \mathrm{Rn}$, ${ }^{223} \mathrm{At}$, and ${ }^{228} \mathrm{Ra}$ were not given in NCRP (1999 [DIRS 155894]). The dose coefficients for ${ }^{212} \mathrm{Po},{ }^{213} \mathrm{Po}$, and ${ }^{228} \mathrm{Ra}$ are equal to 0 (Eckerman and Ryman 1993 [DIRS 107684], Table III.7); therefore, a shielding factor of 0 was selected. For the remaining radionuclides, the chosen value for the shielding factor was based on the type and energy of the radionuclide emissions and the criteria described above. 
In the biosphere model, some primary radionuclides are considered together with their short-lived decay products (see Table 6-28). For such radionuclides, the highest shielding factor for a primary radionuclide and its decay products was selected to ensure that the risk of external exposure was not underestimated. 


\begin{tabular}{|c|c|c|c|c|c|}
\hline Primary Radionuclide & $\begin{array}{c}\text { Short-lived Decay } \\
\text { Products }\end{array}$ & Shielding Factor & Primary Radionuclide & Decay Products & $\begin{array}{l}\text { Shielding } \\
\text { Factor }\end{array}$ \\
\hline Carbon-14 $\left({ }^{14} \mathrm{C}\right)$ & & $0.2^{\mathrm{a}}$ & & & \\
\hline Chlorine-36 $\left({ }^{36} \mathrm{Cl}\right)$ & & 0.4 & & & \\
\hline Selenium-79 $\left({ }^{79} \mathrm{Se}\right)$ & & 0.1 & & & \\
\hline \multirow[t]{2}{*}{ Strontium-90 $\left({ }^{90} \mathrm{Sr}\right)$} & & $0.3(0.4)^{b}$ & & & \\
\hline & Yttrium-90 $\left({ }^{90} \mathrm{Y}\right)$ & 0.4 & & & \\
\hline Technetium-99 $\left({ }^{99} \mathrm{Tc}\right)$ & & 0.2 & & & \\
\hline \multirow[t]{3}{*}{ Tin-126 $\left({ }^{126} \mathrm{Sn}\right)$} & & $0.4(0.4)^{b}$ & & & \\
\hline & Antimony-126m $\left({ }^{126 m} \mathrm{Sb}\right)$ & 0.4 & & & \\
\hline & Antimony-126 $\left({ }^{126} \mathrm{Sb}\right)$ & 0.4 & & & \\
\hline lodine-129 $\left({ }^{129} \mathrm{l}\right)$ & & 0.1 & & & \\
\hline Cesium-135 ( $\left.{ }^{135} \mathrm{Cs}\right)$ & & 0.1 & & & \\
\hline \multirow[t]{2}{*}{ Cesium-137 ( $\left.{ }^{137} \mathrm{Cs}\right)$} & & $0.3(0.4)^{b}$ & & & \\
\hline & Barium-137m $\left({ }^{137 m} \mathrm{Ba}\right)$ & 0.4 & & & \\
\hline \multicolumn{3}{|c|}{ Thorium Series $(4 n)$} & \multicolumn{3}{|c|}{ Neptunium Series $(4 n+1)$} \\
\hline Plutonium-240 $\left({ }^{240} \mathrm{Pu}\right)$ & & 0.1 & Americium-241 ( $\left.{ }^{241} \mathrm{Am}\right)$ & & 0.2 \\
\hline Uranium-236 $\left({ }^{236} U\right)$ & & 0.1 & Neptunium-237 $\left({ }^{237} \mathrm{~Np}\right)$ & & $0.3(0.4)^{b}$ \\
\hline Thorium-232 ( $\left.{ }^{232} \mathrm{Th}\right)$ & & 0.2 & & Protactinium-233 $\left({ }^{233} \mathrm{~Pa}\right)$ & 0.4 \\
\hline \multirow[t]{2}{*}{ Radium-228 $\left({ }^{228} \mathrm{Ra}\right)$} & & $0.0^{a}(0.4)^{b}$ & Uranium-233 $\left({ }^{233} U\right)$ & & 0.4 \\
\hline & Actinium-228 $\left({ }^{228} \mathrm{Ac}\right)$ & 0.4 & Thorium-229 $\left({ }^{229} \mathrm{Th}\right)$ & & $0.4(0.4)^{b}$ \\
\hline Uranium-232 $\left({ }^{232} \mathrm{U}\right)$ & & 0.3 & & Radium-225 $\left({ }^{225} \mathrm{Ra}\right)$ & 0.1 \\
\hline \multirow[t]{8}{*}{ Thorium-228 ( $\left.{ }^{228} \mathrm{Th}\right)$} & & $0.4(0.4)^{b}$ & & Actinium-225 ( $\left.{ }^{225} \mathrm{Ac}\right)$ & 0.4 \\
\hline & Radium-224 $\left({ }^{224} \mathrm{Ra}\right)$ & 0.4 & & Francium-221 $\left({ }^{221} \mathrm{Fr}\right)$ & 0.4 \\
\hline & Radon-220 $\left({ }^{220} \mathrm{Rn}\right)$ & 0.4 & & Astatine-217 $\left({ }^{217} \mathrm{At}\right)$ & 0.4 \\
\hline & Polonium-216 ( $\left.{ }^{216} \mathrm{Po}\right)$ & 0.4 & & Bismuth-213 $\left({ }^{213} \mathrm{Bi}\right)$ & 0.4 \\
\hline & Lead-212 ( $\left.{ }^{212} \mathrm{~Pb}\right)$ & 0.4 & & Polonium-213 $\left({ }^{213} \mathrm{Po}\right)$ & $0.0^{\mathrm{a}}$ \\
\hline & Bismuth-212 ( $\left.{ }^{212} \mathrm{Bi}\right)$ & 0.4 & & Thallium-209 $\left({ }^{209} \mathrm{TI}\right)$ & 0.4 \\
\hline & Polonium-212 ( $\left.{ }^{212} \mathrm{Po}\right)$ & $0.0^{\mathrm{a}}$ & & Lead-209 $\left({ }^{209} \mathrm{~Pb}\right)$ & 0.3 \\
\hline & Thallium-208 ( $\left.{ }^{208} \mathrm{TI}\right)$ & 0.3 & & & \\
\hline
\end{tabular}




\begin{tabular}{|c|c|c|c|c|c|}
\hline Primary Radionuclide & $\begin{array}{c}\text { Short-lived Decay } \\
\text { Products }\end{array}$ & Shielding Factor & Primary Radionuclide & Decay Products & $\begin{array}{l}\text { Shielding } \\
\text { Factor }\end{array}$ \\
\hline \multicolumn{3}{|c|}{ Uranium Series $(4 n+2)$} & \multicolumn{3}{|c|}{ Actinium Series $(4 n+3)$} \\
\hline Plutonium-242 $\left({ }^{242} \mathrm{Pu}\right)$ & & 0.1 & Americium-243 $\left({ }^{243} \mathrm{Am}\right)$ & & $0.3(0.4)^{b}$ \\
\hline \multirow[t]{4}{*}{ Uranium-238 $\left({ }^{238} \mathrm{U}\right)$} & & $0.1(0.4)^{b}$ & & Neptunium-239 ( $\left.{ }^{239} \mathrm{~Np}\right)$ & 0.4 \\
\hline & Thorium-234 ( $\left.{ }^{234} \mathrm{Th}\right)$ & 0.3 & Plutonium-239 $\left({ }^{239} \mathrm{Pu}\right)$ & & 0.3 \\
\hline & Protactinium-234m $\left({ }^{234 m} \mathrm{~Pa}\right)$ & 0.4 & Uranium-235 $\left({ }^{235} \mathrm{U}\right)$ & & 0.4 \\
\hline & Protactinium-234 $\left({ }^{234} \mathrm{~Pa}\right)$ & 0.4 & & Thorium-231 ( $\left.{ }^{231} \mathrm{Th}\right)$ & 0.3 \\
\hline Plutonium-238 $\left({ }^{238} \mathrm{Pu}\right)$ & & 0.1 & Protactinium-231 $\left({ }^{231} \mathrm{~Pa}\right)$ & & 0.4 \\
\hline Uranium-234 $\left({ }^{234} U\right)$ & & 0.2 & Actinium-227 $\left({ }^{227} \mathrm{Ac}\right)$ & & $0.4(0.4)^{b}$ \\
\hline Thorium-230 ( $\left.{ }^{230} \mathrm{Th}\right)$ & & 0.3 & & Thorium-227 ( $\left.{ }^{227} \mathrm{Th}\right)$ & 0.4 \\
\hline \multirow[t]{8}{*}{ Radium-226 $\left({ }^{226} \mathrm{Ra}\right)$} & & $0.4(0.4)^{b}$ & & Francium-223 $\left({ }^{223} \mathrm{Fr}\right)$ & 0.3 \\
\hline & Radon-222 ( $\left.{ }^{222} \mathrm{Rn}\right)$ & $0.0^{\mathrm{a}}$ & & Radium-223 $\left({ }^{223} \mathrm{Ra}\right)$ & 0.4 \\
\hline & Polonium-218 ( $\left.{ }^{218} \mathrm{Po}\right)$ & 0.4 & & Radon-219 ( $\left.{ }^{219} \mathrm{Rn}\right)$ & 0.4 \\
\hline & Lead-214 $\left({ }^{214} \mathrm{~Pb}\right)$ & 0.4 & & Polonium-215 $\left({ }^{215} \mathrm{Po}\right)$ & 0.4 \\
\hline & Astatine-218 ( $\left.{ }^{218} \mathrm{At}\right)$ & 0.1 & & Lead-211 $\left({ }^{211} \mathrm{~Pb}\right)$ & 0.4 \\
\hline & Bismuth-214 $\left({ }^{214} \mathrm{Bi}\right)$ & 0.4 & & Bismuth-211 $\left({ }^{211} \mathrm{Bi}\right)$ & 0.4 \\
\hline & Polonium-214 $\left({ }^{214} \mathrm{Po}\right)$ & 0.4 & & Thallium-207 $\left({ }^{207} \mathrm{TI}\right)$ & 0.4 \\
\hline & Thallium-210 $\left({ }^{210} \mathrm{TI}\right)$ & $0.4^{a}$ & & Polonium-211 ( $\left.{ }^{211} \mathrm{Po}\right)$ & 0.4 \\
\hline \multirow{3}{*}{ Lead-210 ( $\left.{ }^{210} \mathrm{~Pb}\right)$} & & $0.1(0.4)^{b}$ & & & \\
\hline & Bismuth-210 $\left({ }^{210} \mathrm{Bi}\right)$ & 0.4 & & & \\
\hline & Polonium-210 $\left({ }^{210} \mathrm{Po}\right)$ & 0.4 & & & \\
\hline
\end{tabular}

Source: NCRP 1999 (DIRS 155894), Appendix C.

a Shielding factor for ${ }^{14} \mathrm{C},{ }^{210} \mathrm{TI},{ }^{212} \mathrm{Po},{ }^{213} \mathrm{Po},{ }^{222} \mathrm{Rn}$, and ${ }^{228} \mathrm{Ra}$ were not given in the NCRP report (NCRP 1999 [DIRS 155894]). The dose coefficients for ${ }^{212} \mathrm{Po}$, ${ }^{213} \mathrm{Po}$, and ${ }^{228} \mathrm{Ra}$ are equal to 0 (Eckerman and Ryman 1993 [DIRS 107684], Table III.7), so the value of the shielding factor equal to 0 was selected. For the remaining radionuclides, the value of the shielding factor was determined based on the type and energy of the radionuclide emissions and the criteria described above as follows:

${ }^{14} \mathrm{C}$ - beta emitter, average energy less than $100 \mathrm{keV}$ (Lide and Frederikse 1997 [DIRS 103178], p. 11-42); shielding factor $=0.2$;

${ }^{210} \mathrm{TI}$ - beta/gamma emitter, gamma energy greater than $100 \mathrm{keV}$ (Lide and Frederikse 1997 [DIRS 103178], p. 11-125); shielding factor =0.4;

${ }^{222} \mathrm{Rn}$ - alpha emitter, no penetrating radiation (Eckerman and Ryman 1993 [DIRS 107684], Table A.1); shielding factor $=0.0$.

${ }^{\mathrm{b}}$ For the primary radionuclides considered in the biosphere model together with their short-lived decay products, only one value of shielding factor was assigned,

the highest of the values for individual radionuclides. This value is given in parentheses next to the shielding factor for the primary radionuclide. 


\section{CONCLUSIONS}

This section provides a summary of the values of parameters pertaining to the characteristics of the receptor for the biosphere model. These data, which constitute an output of this analysis, are included in the data set identified by DTN: MO0407SPACRBSM.002.

A restriction for subsequent use of the conclusions of this analysis is that the values of receptor characteristics were developed specifically for use in the biosphere model and to comply with the requirements of 10 CFR 63, and therefore may not be appropriate for other applications. Uncertainties in the parameter values are addressed in Section 6.

\subsection{PARAMETER VALUES}

\subsubsection{Lifestyle Characteristics of the Receptor}

\subsubsection{Proportion of Population}

Uniform distributions with minimum and maximum values shown in Table 7-1 are to be used in biosphere model for proportion of non-workers, commuters, and local outdoor workers. Different distributions are to be used for the groundwater and volcanic ash exposure scenarios. The summary of the values is presented in Table 7-1.

Table 7-1. Proportion of the Amargosa Valley Population in Occupation Categories

\begin{tabular}{|c|c|c|c|}
\hline \multirow[b]{2}{*}{ Group } & \multirow[b]{2}{*}{ Estimated Proportion } & \multicolumn{2}{|c|}{ Uniform Distribution } \\
\hline & & Minimum & Maximum \\
\hline \multicolumn{4}{|c|}{ Groundwater Exposure Scenario } \\
\hline Non-Workers & $39.2 \%$ & $34.4 \%$ & $44.0 \%$ \\
\hline Commuters & $39.2 \%$ & $33.9 \%$ & $44.5 \%$ \\
\hline Local Outdoor Workers & $5.5 \%$ & $2.9 \%$ & $8.1 \%$ \\
\hline Local Indoor Workers $^{\mathrm{a}}$ & $16.1 \%$ & & \\
\hline \multicolumn{4}{|c|}{ Volcanic Ash Exposure Scenario } \\
\hline Non-Workers & $39.2 \%$ & $34.4 \%$ & $44.0 \%$ \\
\hline Commuters & $12.5 \%$ & $4.9 \%$ & $16.3 \%$ \\
\hline Local Outdoor Workers & $5.5 \%$ & $2.9 \%$ & $10.7 \%$ \\
\hline Local Indoor Workers $^{\mathrm{a}}$ & $42.8 \%$ & & \\
\hline
\end{tabular}

${ }^{a}$ Calculated in the biosphere model as 100 percent minus the sum of the other three percentages; therefore, a standard error and distribution are not presented.

\subsubsection{Exposure Times by Population Group and Environment}

Lognormal distributions of exposure times, with arithmetic means, standard deviations, and bounds summarized in Table 7-2, are to be used to calculate time spent away from contaminated environments, and in the active outdoor, inactive outdoor, and asleep indoor environments. Different distributions are to be used for the groundwater and volcanic ash exposure scenarios. 
Table 7-2. Daily Exposure Times for Amargosa Valley Population Groups

\begin{tabular}{|c|c|c|c|c|c|c|c|c|}
\hline \multirow{2}{*}{$\begin{array}{l}\text { Population Group/ } \\
\text { Environment }\end{array}$} & \multicolumn{4}{|c|}{ Groundwater Scenario (hours/day) } & \multicolumn{4}{|c|}{ Volcanic Ash Scenario (hours/day) } \\
\hline & AM & SE & Min & $\operatorname{Max}$ & AM & SE & Min & $\operatorname{Max}$ \\
\hline \multicolumn{9}{|l|}{ Non-Workers } \\
\hline Away & 2.0 & 0.4 & 1.2 & 3.3 & 2.0 & 0.4 & 1.2 & 3.3 \\
\hline Active Outdoors & 0.3 & 0.1 & 0.1 & 0.7 & 0.3 & 0.1 & 0.1 & 0.7 \\
\hline Inactive Outdoors & 1.2 & 0.2 & 0.8 & 1.8 & 1.2 & 0.2 & 0.8 & 1.8 \\
\hline Asleep Indoors & 8.3 & 0.1 & 8.0 & 8.6 & 8.3 & 0.1 & 8.0 & 8.6 \\
\hline Active Indoors $^{a}$ & 12.2 & & & & 12.2 & & & \\
\hline \multicolumn{9}{|c|}{ Commuters } \\
\hline Away & 8.0 & 0.5 & 6.8 & 9.4 & 8.3 & 0.6 & 6.9 & 10.0 \\
\hline Active Outdoors & 0.3 & 0.1 & 0.1 & 0.7 & 0.3 & 0.1 & 0.1 & 0.7 \\
\hline Inactive Outdoors & 1.4 & 0.2 & 1.0 & 2.0 & 2.0 & 0.2 & 1.5 & 2.6 \\
\hline Asleep Indoors & 8.3 & 0.1 & 8.0 & 8.6 & 8.3 & 0.1 & 8.0 & 8.6 \\
\hline Active Indoors $^{a}$ & 6.0 & & & & 5.1 & & & \\
\hline \multicolumn{9}{|l|}{ Local Outdoor Workers } \\
\hline Away & 2.0 & 0.4 & 1.2 & 3.3 & 2.0 & 0.4 & 1.2 & 3.3 \\
\hline Active Outdoors & 3.1 & 0.2 & 2.6 & 3.7 & 3.1 & 0.2 & 2.6 & 3.7 \\
\hline Inactive Outdoors & 4.0 & 0.3 & 3.3 & 4.8 & 4.2 & 0.3 & 3.5 & 5.0 \\
\hline Asleep Indoors & 8.3 & 0.1 & 8.0 & 8.6 & 8.3 & 0.1 & 8.0 & 8.6 \\
\hline Active Indoors $^{\mathrm{a}}$ & 6.6 & & & & 6.4 & & & \\
\hline \multicolumn{9}{|c|}{ Local Indoor Workers } \\
\hline Away & 2.0 & 0.4 & 1.2 & 3.3 & 2.0 & 0.4 & 1.2 & 3.3 \\
\hline Active Outdoors & 0.3 & 0.1 & 0.1 & 0.7 & 0.3 & 0.1 & 0.1 & 0.7 \\
\hline Inactive Outdoors & 1.3 & 0.2 & 0.9 & 1.9 & 1.5 & 0.2 & 1.1 & 2.1 \\
\hline Asleep Indoors & 8.3 & 0.1 & 8.0 & 8.6 & 8.3 & 0.1 & 8.0 & 8.6 \\
\hline Active Indoors $^{\mathrm{a}}$ & 12.1 & & & & 11.9 & & & \\
\hline
\end{tabular}

\subsubsection{Breathing Rates}

The summary of the breathing rates is presented in Table 7-3. The breathing rates are to be represented by fixed values.

Table 7-3. Breathing Rates by Population Group and Environment

\begin{tabular}{|l|c|c|c|c|}
\hline \multicolumn{1}{|c|}{ Population Group } & Active Outdoors & Inactive Outdoors & Asleep Indoors & Active Indoors \\
\hline $\begin{array}{l}\text { Commuters } \\
\text { Local Outdoor Workers } \\
\text { Local Indoor Workers } \\
\text { Non-Workers }\end{array}$ & $1.57 \mathrm{~m}^{3} / \mathrm{hr}$ & $1.08 \mathrm{~m}^{3} / \mathrm{hr}$ & $0.39 \mathrm{~m}^{3} / \mathrm{hr}$ & $1.08 \mathrm{~m}^{3} / \mathrm{hr}$ \\
\hline
\end{tabular}

The breathing rates for the adult Amargosa Valley population for different activity levels are summarized in Table 7-4. 
Table 7-4. Breathing Rates Per Level of Activity

\begin{tabular}{|c|c|c|c|c|}
\hline \multicolumn{1}{|c|}{ Population Group } & Sleep & Sitting & Light Exercise & Heavy Exercise \\
\hline Adult, Amargosa Valley & $0.39 \mathrm{~m}^{3} / \mathrm{hr}$ & $0.47 \mathrm{~m}^{3} / \mathrm{hr}$ & $1.38 \mathrm{~m}^{3} / \mathrm{hr}$ & $2.86 \mathrm{~m}^{3} / \mathrm{hr}$ \\
\hline
\end{tabular}

\subsubsection{Evaporative Cooler Use}

The fraction of houses with evaporative coolers is to be represented by a binomial distribution with the probability of 0.738 and the batch size of 187 . The resulting distribution is presented in units of households. Because the biosphere model uses the fraction of the houses with evaporative coolers rather than the number of houses, the sampled value must be divided by the batch size of 187.

The evaporative cooler use factor for the current (i.e., present-day) climate is to be represented by a uniform distribution in the range from 0.32 to 0.46 . For the glacial transition climate, the use factor is to be represented by a uniform distribution with a range of from 0.03 to 0.14 .

\subsubsection{Dietary Characteristics of the Receptor}

\subsubsection{Consumption Rate of Water}

Consumption of water is defined at 10 CFR 63.312 (DIRS 156605) where it is stated that the RMEI drinks 2 liters of water per day, which corresponds to 730.5 liters per year.

\subsubsection{Consumption Rate of Locally Produced Food}

Consumption rates of locally produced food are to be represented by lognormal distributions with the means and standard deviations shown in Table 7-5.

Table 7-5. Annual Consumption Rates of Locally Produced Food by Biosphere Model Food Type

\begin{tabular}{|l|c|c|c|}
\hline \multirow{2}{*}{ Food Type } & \multicolumn{2}{c|}{ Annual consumption rate (kg/yr) } & \multirow{2}{*}{ Distribution } \\
\cline { 2 - 4 } & Mean & Standard Error & Lognormal \\
\hline Leafy vegetables & 3.78 & 0.88 & Lognormal \\
\hline Other vegetables & 4.73 & 0.67 & Lognormal \\
\hline Fruit & 12.68 & 1.36 & Lognormal \\
\hline Grain & 0.23 & 0.11 & Lognormal \\
\hline Meat & 2.85 & 0.65 & Lognormal \\
\hline Poultry & 0.42 & 0.13 & Lognormal \\
\hline Milk & 4.66 & 1.68 & Lognormal \\
\hline Eggs & 5.30 & 0.83 & Lognormal \\
\hline Fish & 0.23 & 0.10 & \\
\hline
\end{tabular}

\subsubsection{Inadvertent Soil Ingestion}

It is recommended that the inadvertent soil ingestion for the RMEI be represented by a piece-wise cumulative probability distribution with the following characteristics: $(50 \mathrm{mg} / \mathrm{d}$, 0 percent), (100 mg/d, 50 percent), and (200 mg/d, 100 percent). 


\subsubsection{Dosimetric Parameters}

\subsubsection{Radionuclide Half-Lives and Branching Fractions}

The half-lives and branching fractions for radionuclides included in the biosphere model are listed in Table 6-23.

\subsubsection{Dose Conversion Factors and Dose Coefficients}

DCFs for inhalation and ingestion for use in the biosphere model are shown in Table 6-24; dose coefficients for exposure to contaminated soil are shown in Table 6-25; and dose coefficients for air submersion and water immersion are shown in Table 6-26. These parameters are to be represented by fixed values.

The DCF for inhalation of ${ }^{222} \mathrm{Rn}$ decay products in equilibrium with radon gas is equal to $1.33 \times 10^{-8} \mathrm{~Sv} / \mathrm{Bq}$.

\subsubsection{Building Shielding Factors}

Building shielding factors for primary radionuclides recommended for use in the biosphere model are listed in Table 7-6.

\subsection{HOW THE APPLICABLE ACCEPTANCE CRITERIA ARE ADDRESSED}

The following information describes how this analysis addresses the acceptance criteria in the Yucca Mountain Review Plan (NRC 2003 [DIRS 163274], Section 2.2.1.3.14). Only those acceptance criteria that are applicable to this report (see Section 4.2) are discussed.

This analysis report is one of ten reports (Figure 1-1) that support biosphere modeling and describe how the acceptance criteria have been addressed by the biosphere model. A consideration of all ten reports is required to understand how all applicable acceptance criteria are satisfied by the biosphere model. 
Table 7-6. Building Shielding Factors for Primary Radionuclides

\begin{tabular}{|c|c|c|c|}
\hline Primary Radionuclide & Shielding Factor & Primary Radionuclide & Shielding Factor \\
\hline Carbon-14 $\left({ }^{14} \mathrm{C}\right)$ & 0.2 & & \\
\hline Chlorine-36 $\left({ }^{36} \mathrm{Cl}\right)$ & 0.4 & & \\
\hline Selenium-79 $\left({ }^{79} \mathrm{Se}\right)$ & 0.1 & & \\
\hline Strontium-90 $\left({ }^{90} \mathrm{Sr}\right)$ & 0.4 & & \\
\hline Technetium-99 $\left({ }^{99} \mathrm{Tc}\right)$ & 0.2 & & \\
\hline Tin-126 $\left({ }^{126} \mathrm{Sn}\right)$ & 0.4 & & \\
\hline lodine-129 $\left({ }^{129} \mathrm{l}\right)$ & 0.1 & & \\
\hline Cesium-135 ( $\left({ }^{135} \mathrm{Cs}\right)$ & 0.1 & & \\
\hline Cesium-137 ( $\left.{ }^{137} \mathrm{Cs}\right)$ & 0.4 & & \\
\hline \multicolumn{2}{|c|}{ Thorium Series $(4 n)$} & \multicolumn{2}{|c|}{ Neptunium Series $(4 n+1)$} \\
\hline Plutonium-240 $\left({ }^{240} \mathrm{Pu}\right)$ & 0.1 & Americium-241 $\left({ }^{241} \mathrm{Am}\right)$ & 0.2 \\
\hline Uranium-236 $\left({ }^{236} \mathrm{U}\right)$ & 0.1 & Neptunium-237 ( $\left.{ }^{237} \mathrm{~Np}\right)$ & 0.4 \\
\hline Thorium-232 $\left({ }^{232} \mathrm{Th}\right)$ & 0.2 & Uranium-233 $\left({ }^{233} \mathrm{U}\right)$ & 0.4 \\
\hline Radium-228 $\left({ }^{228} \mathrm{Ra}\right)$ & 0.4 & Thorium-229 $\left({ }^{229} \mathrm{Th}\right)$ & 0.4 \\
\hline Uranium-232 $\left({ }^{232} U\right)$ & 0.3 & & \\
\hline Thorium-228 $\left({ }^{228} \mathrm{Th}\right)$ & 0.4 & & \\
\hline \multicolumn{2}{|c|}{ Uranium Series $(4 n+2)$} & \multicolumn{2}{|c|}{ Actinium Series $(4 n+3)$} \\
\hline Plutonium-242 $\left({ }^{242} \mathrm{Pu}\right)$ & 0.1 & Americium-243 $\left({ }^{243} \mathrm{Am}\right)$ & 0.4 \\
\hline Uranium-238 $\left({ }^{238} \mathrm{U}\right)$ & 0.4 & Plutonium-239 $\left({ }^{239} \mathrm{Pu}\right)$ & 0.3 \\
\hline Plutonium-238 $\left({ }^{238} \mathrm{Pu}\right)$ & 0.1 & Uranium-235 $\left({ }^{235} \mathrm{U}\right)$ & 0.4 \\
\hline Uranium-234 $\left({ }^{234} U\right)$ & 0.2 & Protactinium-231 $\left({ }^{231} \mathrm{~Pa}\right)$ & 0.4 \\
\hline Thorium-230 $\left({ }^{230} \mathrm{Th}\right)$ & 0.3 & Actinium-227 $\left({ }^{227} \mathrm{Ac}\right)$ & 0.4 \\
\hline Radium-226 $\left({ }^{226} \mathrm{Ra}\right)$ & 0.4 & & \\
\hline Lead-210 $\left({ }^{210} \mathrm{~Pb}\right)$ & 0.4 & & \\
\hline
\end{tabular}

Acceptance Criterion $1 \quad$ System Description and Model Integration are Adequate.

- Subcriterion (3): This analysis considers information and assumptions about climate change that are developed or also considered in other TSPA modeling abstractions. The analysis of the effects of climate change on the evaporative cooler use factor is described in Section 6.3.4.2 and is based on the climate states modeled in other TSPA abstractions (BSC 2003 [DIRS 166296], p. 79).

\section{Acceptance Criterion 2 Data are Sufficient for Model Justification.}

- Subcriterion (1): The justification for the parameter distributions developed in this report, and the consistency of those distributions with the definition of the RMEI in 10 CFR 63, are described in Section 6, with additional justification for assumptions in Section 5. The data identified in Sections 4.1 were used, interpreted, and appropriately synthesized into the parameter distributions as described in Section 6.

- Subcriterion (2): The sufficiency of data used to develop parameter distributions used in the modeling of features, events, and processes related to biosphere characteristics modeling is 
described in Sections 4.1 and 6. Demonstration that the parameter distributions are consistent with present knowledge of the conditions in the Yucca Mountain region is in Section 6. Sensitivity and uncertainty analyses is addressed in other biosphere modeling reports listed in Figure 1-1.

Acceptance Criterion 3 Data Uncertainty is Characterized and Propagated Through the Model Abstraction

- Subcriterion (1): The technical defensibility of assumptions used in this analysis is included in Section 5. The technical defensibility of the probability distribution developed for each parameter is described in Section 6. The identification of uncertainties and variabilities, and how those uncertainties and variabilities were accounted for in the development of parameter bounds that do not under-represent risk, is also described in Section 6. The consistency of parameter distributions and assumptions with the definition of the RMEI in 10 CFR 63 is described throughout Section 6.

- Subcriterion (2): The technical defensibility of the technical bases for the parameter distributions, and their consistency with site characterization data, is described in Section 6.

- Subcriterion (3): No process-level models were used to determine parameter values in this analysis. The consistency of the parameter distributions with site characterization data, laboratory experiments, field measurements, and natural analog research is described in Section 6.

- Subcriterion (4): The bounding values of the parameter distributions developed in this analysis were selected to adequately represent uncertainty, as described in Section 6. No correlations among biosphere model input parameters are identified in this analysis. 


\section{INPUTS AND REFERENCES}

\subsection{DOCUMENTS CITED}

Anspaugh, L.R.; Shinn, J.H.; Phelps, P.L.; and Kennedy, N.C. 1975. "Resuspension 151548 and Redistribution of Plutonium in Soils.” Health Physics, 29, (4), 571-582.

New York, New York: Pergamon Press. TIC: 248619.

Bevington, P.R. and Robinson, D.K. 1992. Data Reduction and Error Analysis for 147076 the Physical Sciences. 2nd Edition. New York, New York: McGraw-Hill. TIC: 243514.

Binkowitz, B.S.; and Wartenberg, D. 2001. "Disparity in Quantitative Risk 168389 Assessment : A Review of Input Distributions.” Risk Analysis, 21, (1), 75-90. Oxford, England: Blackwell. TIC: 255623.

BSC (Bechtel SAIC Company) 2001. Calculation: Consumption Rates of Locally Produced Food in Nye and Lincoln Counties. CAL-MGR-EV-000002 REV 00 Las Vegas, Nevada: Bechtel SAIC Company. ACC: MOL.20010628.0242.

BSC 2003. Total System Performance Assessment-License Application Methods and Approach. TDR-WIS-PA-000006 REV 00 ICN 01. Las Vegas, Nevada: Bechtel SAIC Company. ACC: DOC.20031215.0001.

BSC 2003. Yucca Mountain Project Summary of Socioeconomic Data Analyses Conducted in Support of the Radiological Monitoring Program, During FY 2003. TDR-MGR-EV-000040 REV 00. Las Vegas, Nevada: Bechtel SAIC Company. ACC: DOC.20031203.0003.

BSC 2004. Analysis of 1993-1997 Meteorological Data from Yucca Mountain Site 9. 167055 ANL-MGR-MM-000001 REV 00. Las Vegas, Nevada: Bechtel SAIC Company. ACC: DOC.20040126.0002.

BSC 2004. Atmospheric Dispersal and Deposition of Tephra from a Potential 170026 Volcanic Eruption at Yucca Mountain, Nevada. MDL-MGR-GS-000002 REV 01. Las Vegas, Nevada: Bechtel SAIC Company.

BSC 2004. Biosphere Dose Conversion Factor Importance and Sensitivity Analysis. 170016 ANL-NBS-MD-000014 REV 00. Las Vegas, Nevada: Bechtel SAIC Company.

BSC 2004. Biosphere Model Report. MDL-MGR-MD-000001 REV 01. Las Vegas, 169460 Nevada: Bechtel SAIC Company.

BSC 2004. Characterize Eruptive Processes at Yucca Mountain, Nevada. 169980 ANL-MGR-GS-000002 REV 02. Las Vegas, Nevada: Bechtel SAIC Company. 
BSC 2004. Disruptive Event Biosphere Dose Conversion Factor Analysis.

167287 ANL-MGR-MD-000003 REV 03. Las Vegas, Nevada: Bechtel SAIC Company.

BSC 2004. Future Climate Analysis. ANL-NBS-GS-000008, Rev. 01. Las Vegas, 170002 Nevada: Bechtel SAIC Company.

BSC 2004. Nominal Performance Biosphere Dose Conversion Factor Analysis. ANL-MGR-MD-000009 REV 03. Las Vegas, Nevada: Bechtel SAIC Company.

BSC 2004. Q-List. 000-30R-MGR0-00500-000-000 REV 00. Las Vegas, Nevada: Bechtel SAIC Company. ACC: ENG.20040721.0007.

BSC 2004. Technical Work Plan for Biosphere Modeling and Expert Support. TWP-NBS-MD-000004 REV 03. Las Vegas, Nevada: Bechtel SAIC Company. ACC: DOC.20040527.0004.

Bulmer, M.G. 1979. Principles of Statistics. 3rd Edition. New York, New York: Dover. TIC: 245835.

Bureau of the Census. 2001. Statistical Abstract of the United States: 2001. 121st Edition. Washington, D.C.: U.S. Department of Commerce, Bureau of the Census. TIC: 252180.

Bureau of the Census. 2002. “Accuracy of the Data.” Chapter 8 of 2000 Census of Population and Housing, Summary File 3, Technical Documentation. Washington, D.C.: U.S. Department of Commerce, Bureau of the Census. TIC: 253100.

Bureau of the Census. 2002. "2000 Summary File 3 (SF 3) Sample Data, Amargosa Valley CCD, Nye County, Nevada.” Washington, D.C.: U.S. Department of Commerce, Bureau of the Census. Accessed August 28, 2002. TIC: 253098. http://factfinder.census.gov/servlet/DTTable?_ts=48597952130

Canori, G.F. and Leitner, M.M. 2003. Project Requirements Document. 166275 TER-MGR-MD-000001 REV 02. Las Vegas, Nevada: Bechtel SAIC Company. ACC: DOC.20031222.0006.

Castor, S.B. 2001. “Industrial Minerals.” The Nevada Mineral Industry 2000. Meeuwig, D., ed. Special Publication MI-2000. 39-42. Reno, Nevada: Nevada Bureau of Mines and Geology. TIC: 252603.

CRWMS (Civilian Radioactive Waste Management System) M\&O (Management and 101090 Operating Contractor) 1997. Yucca Mountain Site Characterization Project Summary of Socioeconomic Data Analyses Conducted in Support of the Radiological Monitoring Program First Quarter 1996 to First Quarter 1997. Las Vegas, Nevada: CRWMS M\&O. ACC: MOL.19971117.0460. 
CRWMS M\&O 1999. Environmental Baseline File for Meteorology and Air Quality. B00000000-01717-5705-00126 REV 00. Las Vegas, Nevada: CRWMS M\&O.

ACC: MOL.19990302.0186.

CRWMS M\&O 2000. Total System Performance Assessment for the Site

153246

Recommendation. TDR-WIS-PA-000001 REV 00 ICN 01. Las Vegas, Nevada:

CRWMS M\&O. ACC: MOL.20001220.0045.

Davis, D.A. 2001. "Directory of Mining and Milling Operations.” The Nevada

160096

Mineral Industry 2000. Nevada Bureau of Mines and Geology Special Publication

MI-2000. 55-61. Reno, Nevada: University of Nevada, Reno, Mackay School of

Mines. TIC: 252603.

DOE (U.S. Department of Energy) 1997. The 1997 “Biosphere” Food Consumption

100332

Survey Summary Findings and Technical Documentation. Las Vegas, Nevada: U.S.

Department of Energy, Office of Civilian Radioactive Waste Management.

ACC: MOL.19981021.0301.

DOE 2001. Yucca Mountain Science and Engineering Report. DOE/RW-0539.

153849

Washington, D.C.: U.S. Department of Energy, Office of Civilian Radioactive Waste

Management. ACC: MOL.20010524.0272.

Dorrian, M.-D. 1997. "Particle Size Distributions of Radioactive Aerosols in the

159476

Environment.” Radiation Protection Dosimetry, 69, (2), 117-132. Ashford, Kent, England: Nuclear Technology Publishing. TIC: 252686.

Driesner, D. and Coyner, A. 2001. Major Mines of Nevada 2000, Mineral Industries

160175 in Nevada's Economy. Nevada Bureau of Mines and Geology Special Publication P-12. Reno, Nevada: University of Nevada Reno, Mackay School of Mines.

TIC: 252602.

Duan, N. 1982. "Models for Human Exposure to Air Pollution.” Environment

162466

International, 8, 305-309. New York, New York: Pergamon Press. TIC: 250558.

Eckerman, K.F. and Ryman, J.C. 1993. External Exposure to Radionuclides in Air,

107684 Water, and Soil, Exposure-to-Dose Coefficients for General Application, Based on the 1987 Federal Radiation Protection Guidance. EPA 402-R-93-081. Federal Guidance Report No. 12. Washington, D.C.: U.S. Environmental Protection Agency, Office of Radiation and Indoor Air. TIC: 225472.

Eckerman, K.F.; Wolbarst, A.B.; and Richardson, A.C.B. 1988. Limiting Values of 101069 Radionuclide Intake and Air Concentration and Dose Conversion Factors for Inhalation, Submersion, and Ingestion. EPA 520/1-88-020. Federal Guidance Report No. 11. Washington, D.C.: U.S. Environmental Protection Agency.

ACC: MOL.20010726.0072. 
EPA (U.S. Environmental Protection Agency) 1996. Air Quality Criteria for 160121 Particulate Matter. EPA/600/P-95/001. Three volumes. Washington, D.C.: U.S. Environmental Protection Agency. TIC: 250648.

EPA 1997. Activity Factors. Volume III of Exposure Factors Handbook.

EPA/600/P-95/002Fc. Washington, D.C.: U.S. Environmental Protection Agency. TIC: 241062.

EPA 1997. General Factors. Volume I of Exposure Factors Handbook. 103038 EPA/600/P-95/002Fa. Washington, D.C.: U.S. Environmental Protection Agency. TIC: 241060.

Golder Associates. 2000. GoldSim, Graphical Simulation Environment, User's 146973 Guide. Version 6.02. Manual Draft \#4 (March 17, 2000). Redmond, Washington: Golder Associates. TIC: 247347.

ICRP (International Commission on Radiological Protection) 1981. Limits for 163051 Inhalation of Radon Daughters by Workers. Volume 6, No. 1 of Annals of the ICRP, ICRP Publication 32. Pages 6-15. New York, New York: Pergamon Press.

TIC: 254211.

ICRP 1982. Limits for Intakes of Radionuclides by Workers. Volume 7, No. 1-3 of 163147 Annals of the ICRP. ICRP Publication 30, Supplement A to Part 3. Reprinted 1990. New York, New York: Pergamon Press. TIC: 4944.

ICRP 1977. Recommendations of the International Commission on Radiological 101075 Protection. Volume 1, No. 3 of Annals of the ICRP. ICRP Publication 26. Reprinted 1982. New York, New York: Pergamon Press. TIC: 221568.

ICRP 1978. Limits for Intakes of Radionuclides by Workers. Annals of the ICRP. 101076 ICRP Publication 30 Supplement to Part 1. New York, New York: Pergamon Press. TIC: 221575.

ICRP 1979. Limits for Intakes of Radionuclides by Workers. Volume 2, No. 3/4 of Annals of the ICRP. Sowby, F.D., ed. ICRP Publication 30 Part 1. New York, New York: Pergamon Press. TIC: 4939.

ICRP 1980. Limits for Intakes of Radionuclides by Workers. Volume 4, No. 3/4 of Annals of the ICRP. Sowby, F.D., ed. ICRP Publication 30 Part 2. Reprinted 1990. Elmsford, New York: Pergamon Press. TIC: 4941.

ICRP 1981. Limits for Intakes of Radionuclides by Workers. Volume 5, No. 1-6 of 153056 Annals of the ICRP. ICRP Publication 30, Supplement to Part 2. New York, New York: Pergamon Press. TIC: 4942. 
ICRP 1981. Limits for Intakes of Radionuclides by Workers. Volume 6, No. 2/3 of Annals of the ICRP. Sowby, F.D., ed. ICRP Publication 30 Part 3, Including Addendum to Parts 1 and 2. New York, New York: Pergamon Press. TIC: 4943.

ICRP 1982. Limits for Intakes of Radionuclides by Workers. Volume 8, No. 1-3 of 153057 Annals of the ICRP. ICRP Publication 30, Supplement B to Part 3 Including Addendum to the Supplements of Parts 1 and 2. New York, New York: Pergamon Press. TIC: 4945.

ICRP 1991. "1990 Recommendations of the International Commission on 101836 Radiological Protection.” Volume 21, No. 1-3 of Annals of the ICRP. ICRP Publication 60. New York, New York: Pergamon Press. TIC: 235864.

ICRP 1994. Human Respiratory Tract Model for Radiological Protection. Volume 24, Nos. 1-3 of Annals of the ICRP. Smith, H., ed. ICRP Publication 66. New York, New York: Pergamon. TIC: 249223.

ICRP 1996. Age-Dependent Doses to Members of the Public from Intake of 152446 Radionuclides: Part 5 Compilation of Ingestion and Inhalation Dose Coefficients. Volume 26, No. 1 of Annals of the ICRP. Smith, H., ed. ICRP Publication 72. New York, New York: Pergamon Press. TIC: 235870.

Jarzemba, M.S.; LaPlante, P.A.; and Poor, K.J. 1997. ASHPLUME Version 1.0—A Code for Contaminated Ash Dispersal and Deposition, Technical Description and User's Guide. CNWRA 97-004, Rev. 1. San Antonio, Texas: Center for Nuclear Waste Regulatory Analyses. ACC: MOL.20010727.0162.

Karpiscak, M.M.; Babcock, T.M.; France, G.W.; Zauderer, J.; Hopf, S.B.; and Foster, K.E. 1998. "Evaporative Cooler Water Use in Phoenix.” Journal, American Water Works Association, 90, (4), 121-130. [New York, New York]: American Water Works Association. TIC: 253423.

Klepeis, N.E. 1999. “An Introduction to the Indirect Exposure Assessment 160094 Approach: Modeling Human Exposure Using Microenvironmental Measurements and the Recent National Human Activity Pattern Survey.” Environmental Health Perspectives, 107, (Supplement 2), 365-374. Research Park Triangle, North Carolina: National Institute of Environmental Health Sciences, National Institutes of Health. TIC: 250567.

Klepeis, N.E.; Tsang, A.M.; and Behar, J.V. 1996. Analysis of the National Human Activity Pattern Survey (NHAPS) Respondents from a Standpoint of Exposure Assessment, Percentage of Time Spent, Duration, and Frequency of Occurrence for Selected Microenvironments by Gender, Age, Time-of-day, Day-of-week, Season, and U.S. Census Region, Final Report. EPA/600/R-96/074. Washington, D.C.: U.S. Environmental Protection Agency, Office of Research and Development. TIC: 252656. 
Knoll, G.F. 1989. Radiation Detection and Measurement. 2nd Edition. New York, 161052 New York: John Wiley \& Sons. TIC: 233703.

LaPlante, P.A. and Poor, K. 1997. Information and Analyses to Support Selection of 101079 Critical Groups and Reference Biospheres for Yucca Mountain Exposure Scenarios. CNWRA 97-009. San Antonio, Texas: Center for Nuclear Waste Regulatory Analyses. ACC: MOL.20010721.0035.

Lide, D.R. and Frederikse, H.P.R., eds. 1997. CRC Handbook of Chemistry and 103178 Physics. 78th Edition. Boca Raton, Florida: CRC Press. TIC: 243741.

Mage, D.T. 1985. "Concepts of Human Exposure Assessment for Airborne 162465 Particulate Matter.” Environment International, 11, 407-412. New York, New York: Pergamon Press. TIC: 250582.

NCDC (National Climatic Data Center) [n.d.]. Hourly United States Weather Observations 1990-1995. Washington, D.C.: U.S. Department of Commerce, National Oceanic and Atmospheric Administration. TIC: 253573.

NCRP (National Council on Radiation Protection and Measurements) 1997. Deposition, Retention and Dosimetry of Inhaled Radioactive Substances. NCRP Report No. 125. Bethesda, Maryland: National Council on Radiation Protection and Measurements. TIC: 232976.

NCRP 1998. Evaluating the Reliability of Biokinetic and Dosimetric Models and Parameters Used to Assess Individual Doses for Risk Assessment Purposes. NCRP Commentary No. 15. Bethesda, Maryland: National Council on Radiation Protection and Measurements. TIC: 252922.

NCRP 1999. Recommended Screening Limits for Contaminated Surface Soil and Review of Factors Relevant to Site-Specific Studies. NCRP Report No. 129. Bethesda, Maryland: National Council on Radiation Protection and Measurements. TIC: 250396.

Nevada Department of Minerals; Nevada Bureau of Mines and Geology; and Mackay 160176 School of Mines. 1991. Major Mines of Nevada, 1990. Nevada Bureau of Mines and Geology Special Publication 11. Reno, Nevada: University of Nevada Reno, Mackay School of Mines. TIC: 222736.

Nicholson, K.W. 1988. “A Review of Particle Resuspension.” Atmospheric Environment, 22, (12), 2639-2651. New York, New York: Pergamon Press. TIC 252279.

Nieuwenhuijsen, M.J.; Kruize, H.; and Schenker, M.B. 1998. "Exposure to Dust and Its Particle Size Distribution in California Agriculture.” American Industrial Hygiene Association Journal, 59, 34-38. Fairfax, Virginia: American Industrial Hygiene Association. TIC: 248134. 
NRC (U.S. Nuclear Regulatory Commission) 2003. Use of the Effective Dose

163018 Equivalent in Place of the Deep Dose Equivalent in Dose Assessments. RIS 2003-04. Washington, D.C.: U.S. Nuclear Regulatory Commission. TIC: 254200.

NRC 2003. Yucca Mountain Review Plan, Final Report. NUREG-1804, Rev. 2. 163274 Washington, D.C.: U.S. Nuclear Regulatory Commission, Office of Nuclear Material Safety and Safeguards. TIC: 254568.

NRC 2000. A Performance Assessment Methodology for Low-Level Radioactive 157704 Waste Disposal Facilities, Recommendations of NRC's Performance Assessment Working Group. NUREG-1573. Washington, D.C.: U.S. Nuclear Regulatory Commission. TIC: 252174.

Pinnick, R.G.; Fernandez, G.; Hinds, B.D.; Bruce, C.W.; Schaefer, R.W.; and 159577 Pendleton, J.D. 1985. "Dust Generated by Vehicular Traffic on Unpaved Roadways: Sizes and Infrared Extinction Characteristics.” Aerosol Science and Technology, 4, (1), 99-121. New York, New York: Elsevier. TIC: 252364.

Pinnick, R.G.; Fernandez, G.; Martinez-Andazola, E.; Hinds, B.D.; Hansen, A.D.A.; 160312 and Fuller, K. 1993. "Aerosol in the Arid Southwestern United States: Measurements of Mass Loading, Volatility, Size Distribution, Absorption Characteristics, Black Carbon Content, and Vertical Structure to $7 \mathrm{~km}$ Above Sea Level.” Journal of Geophysical Research, 98, (D2), 2651-2666. Washington, D.C.: American Geophysical Union. TIC: 252365.

Rasmuson, K.E. 2004. “Summary of 2004 Agricultural Activities, Businesses, and Community Services and Organizations in Amargosa Valley.” Interoffice memorandum from K.E. Rasmuson (BSC) to K.R. Rautenstrauch, May 20, 2004, 0520041667, with enclosures. ACC: MOL.20040519.0033.

Reamer, C.W. and Williams, D.R. 2000. Summary Highlights of NRC/DOE 154597 Technical Exchange and Management Meeting on Igneous Activity. Meeting held August 29-31, 2000, Las Vegas, Nevada, with attachments. Washington, D.C.: U.S. Nuclear Regulatory Commission. ACC: MOL.20001101.0105 through MOL.20001101.0128.

Rittmann, P.D. 1993. Verification Tests for the July 1993 Revision to the GENII 107744 Radionuclide and Dose Increment Libraries. WHC-SD-WM-TI-596. Richland, Washington: Westinghouse Hanford Company. TIC: 233965.

Roe, L.K. 2002. "Summary of RDA Investigation ID: 4/10/02 Fish Farming in 160674 Amargosa Valley.” Interoffice memorandum from L.K. Roe (BSC) to File, November 5, 2002, 1105024986, with an attachment. ACC: MOL.20021107.0091; MOL.20020821.0002. 
Shinn, J.H. 1992. “Enhancement Factors for Resuspended Aerosol Radioactivity: Effects of Topsoil Disturbance." Proceedings of the Fifth International Conference on Precipitation Scavenging and Atmosphere-Surface Exchange Processes, Richland, Washington, 15-19 July 1991. 1183-1193. Washington, D.C.: Hemisphere. TIC: 252292.

Simon, S.L. 1998. "Soil Ingestion by Humans: A Review of History, Data, and 160098 Etiology with Application to Risk Assessment of Radioactively Contaminated Soil.” Health Physics, 74, (6), 647-672. Baltimore, Maryland: Williams \& Wilkins. TIC: 253001.

Stanek, E.J., III.; Calabrese, E.J.; Barnes, R.; and Pekow, P. 1997. “Soil Ingestion in 160251 Adults-Results of a Second Pilot Study.” Ecotoxicology and Environmental Safety, 36, (3), 249-257. San Diego, California: Academic Press. TIC: 252381.

Stanek, E.J. III; and Calabrese, E.J. 2000. "Daily Soil Ingestion Estimates for 168391 Children at a Superfund Site.” Risk Analysis, 20, (5), 627-635. Malden, Massachusetts: Blackwell Publishers. TIC: 252382.

UNSCEAR (United Nations Scientific Committee on the Effects of Atomic Radiation) 2000. Sources and Effects of Ionizing Radiation, United Nations Scientific Committee on the Effects of Atomic Radiation, UNSCEAR 2000 Report to the General Assembly, with Scientific Annexes. Two volumes. New York, New York: United Nations. TIC: 249863.

USDA (U.S. Department of Agriculture) 2000. Food and Nutrient Intakes by Individuals in the United States, 1994-1996. Nationwide Food Surveys Report No. 96-3. Two volumes. Washington, D.C.: U.S. Department of Agriculture. TIC: 249498.

Watt, J.R. and Brown, W.K. 1997. Evaporative Air Conditioning Handbook. 3rd 159497 Edition. Lilburn, Georgia: Fairmont Press. TIC: 252688.

YMP (Yucca Mountain Site Characterization Project) 1999. Yucca Mountain Site 158212 Characterization Project: Summary of Socioeconomic Data Analyses Conducted in Support of the Radiological Monitoring Program, April 1998 to April 1999. North Las Vegas, Nevada: Yucca Mountain Site Characterization Office. ACC: MOL.19991021.0188.

Yu, C.; Zielen, A.J.; Cheng, J.-J.; LePoire, D.J.; Gnanapragasam, E.; Kamboj, S.; 159465 Arnish, J.; Wallo, A., III.; Williams, W.A.; and Peterson, H. 2001. User's Manual for RESRAD Version 6. ANL/EAD-4. Argonne, Illinois: Argonne National Laboratory. TIC: 252702. 


\subsection{CODES, STANDARDS, REGULATIONS, AND PROCEDURES}

10 CFR 20. Energy: Standards for Protection Against Radiation. Readily available. 104787

10 CFR 63. Energy: Disposal of High-Level Radioactive Wastes in a Geologic

156605

Repository at Yucca Mountain, Nevada. Readily available.

40 CFR 197. 2001. Protection of Environment: Public Health and Environmental

155238

Radiation Protection Standards for Yucca Mountain, Nevada. Readily available

66 FR 55732. Disposal of High-Level Radioactive Wastes in a Proposed Geologic

Repository at Yucca Mountain, NV. Final Rule 10 CFR Part 63. Readily available.

AP-2.22Q, Rev. 1, ICN 1. Classification Analyses and Maintenance of the Q-List. Washington, D.C.: U.S. Department of Energy, Office of Civilian Radioactive Waste Management. ACC: DOC.20040714.0002.

AP-2.27Q, Rev. 1, ICN 4. Planning for Science Activities. Washington, D.C.: U.S. Department of Energy, Office of Civilian Radioactive Waste Management. ACC:

DOC.20040610.0006.

AP-SIII.9Q, Rev. 1, ICN 6. Scientific Analyses. Washington, D.C.: U.S. Department of Energy, Office of Civilian Radioactive Waste Management.

ACC: DOC.20040805.0003.

\subsection{SOURCE DATA, LISTED BY DATA TRACKING NUMBERS}

MO0010SPANYE00.001. Cleaned Nye County Food Consumption Frequency

154976

Survey. Submittal date: 10/10/2000.

MO04019SUM9397.000. Summary of 1993-1997 Site 9 Meteorological Data.

167054

Submittal date: 01/20/2004.

MO0407SEPFEPLA.000. LA FEP List. Submittal date: 07/20/2004.

170760

\subsection{OUTPUT DATA, LISTED BY DATA TRACKING NUMBER}

MO0407SPACRBSM.002. Characteristics of the Receptor for the Biosphere Model. Submittal date: 07/19/2004. 


\section{INTENTIONALLY LEFT BLANK}


APPENDIX A

CALCULATION OF CONSUMPTION RATES OF LOCALLY PRODUCED FOOD 


\section{CALCULATION OF CONSUMPTION RATES OF LOCALLY PRODUCED FOOD}

This appendix explains the spreadsheet calculations of consumption rates of locally produced food. The calculations were done using the standard function of Microsoft Excel 97 SR-2. The calculation method is described in Section 6.4.2. The calculations are done in the Excel workbook named Consumption rates with uncertainties.xls. The file is listed in Appendix C. The workbook consists of four worksheets: Histograms, Consumption rates, Survey data, and Consumption rate formulas.

The data in the Excel workbook was extracted from the data set MO0106SPANYE00.001, which contains all data from the 1997 regional survey (see Section 4.1.5). Data from 195 survey respondents having a telephone prefix of 372 were extracted for this analysis. This prefix covered the Amargosa Valley, Lathrop Wells, Ash Meadows, and Crystal areas (DOE 1997 [DIRS 100332], p. 3). Only data from respondents living in this region were extracted, to meet the requirement of 10 CFR 63.312(b) that DOE use projections based on surveys of the people residing in the town of Amargosa Valley. Of the 195 responses, eight were eliminated from further analyses because the respondents were seasonal or part-time residents, had resided in Amargosa Valley for less than 1 year, or refused to answer questions about residency. Of the remaining 187 responses, two were from respondents who stated that they lived in Crystal, one was from someone who stated that she lived in Ash Meadows, and the remainder were from people who stated that they lived in Amargosa Valley (MO0106SPANYE00.001).

In the worksheet Survey data, the effective number of days per year (EDPY) that an individual consumed locally produced food from a given food group is calculated separately for males and females, together with the standard deviation, count, and the standard error of the mean. These calculations are done for 187 individuals residing in the region for at least one year prior to the survey and for 12 food groups that were included in the survey. Equation 6.4-1 was used to calculate EDPY as follows:

$$
E D P Y_{i, j}=M P Y_{i, j} \frac{365.25 d}{12 m o} D P W_{i, j} \frac{1 w k}{7 d} Q_{i, j}
$$

The values of $M P Y, D P W$, and $Q$ for individual food groups are taken from the results of the regional survey residing in the Cleaned Nye County Food Consumption Frequency Survey data set, DTN: MO0010SPANYE00.001 [DIRS 154976]. The individual responses are coded in the data set (and the same coding is maintained in the worksheet) as:

Q3A2-A, Q3A3-A, Q3A4-A for leafy vegetables

Q3B2-A, Q3B3-A, Q3B4-A for root (other) vegetables

Q3C2-A, Q3C3-A, Q3C4-A for grain

Q3D2-A, Q3D3-A, Q3D4-A for fruit

Q3E2-A, Q3E3-A, Q3E4-A for poultry

Q3F2-A, Q3F3-A, Q3F4-A for beef

Q3G2-A, Q3G3-A, Q3G4-A for pork

Q3H2-A, Q3D3-A, Q3D4-A for game

Q3I2-A, Q3I3-A, Q3I4-A for fish 
Q3J2-A, Q3J3-A, Q3J4-A for milk

Q3K2-A, Q3K3-A, Q3K4-A for eggs

Q3M2-A, Q3M3-A, Q3M4-A for tomatoes

For every food group and gender, the mean value of the EDPY is calculated using the AVERAGE function of Excel for the defined range of values for the EDPY. The standard deviation of the EDPY is calculated using STDEV function of Excel for the defined range of cells. The count corresponds to the number of valid numerical EDPY results ("DK or Refuse" and "Invalid" are not included) for a given food group and gender and is calculated using the COUNT Excel function. The standard error of the mean EDPY is calculated by dividing the standard deviation by the square root of the count.

The mean, standard deviation, count, standard error of the mean are carried to the Consumption rates worksheet. The mean and the standard error are subsequently used to calculate the consumption rates, while the standard deviation and the count are only shown to provide the convenient summary of values.

The spreadsheet content is as follows:

\section{Column}

A Identification of food groups used in the regional survey

B Gender designation (the value of average daily intake, $A D I$, of a specific food is gender-specific)

C Mean value of $A D I$ by food group and gender from the USDA Survey of Food Intake (USDA 2000 [DIRS 154158])

D Standard error of the mean ADIs by food group and gender from the USDA Survey of Food Intake (USDA 2000 [DIRS 154158])

E Mean value of the fraction of people consuming, FPC, food from a given food group by food group and gender from the USDA Survey of Food Intake (USDA 2000 [DIRS 154158])

F Standard error of the mean value of FPC food from a given food group by food group and gender from the USDA Survey of Food Intake (USDA 2000 [DIRS 154158])

G not used

$\mathrm{H} \quad$ Mean value of the $C A D I$ by food group and gender calculated as the ratio of $A D I$ (column C) and FPC (column E)

I Standard error of the mean CADI calculated using the following formula (Eq. 6.4-6):

$$
S E M_{C A D I_{i}}=\sqrt{\left(\frac{S E M_{A D I_{i}}}{F P C_{i}}\right)^{2}+\left(\frac{A D I_{i} S E M_{F P C_{i}}}{\left(F P C_{i}\right)^{2}}\right)^{2}}
$$


Column

Where: $S E M_{A D I}$ is taken from column D

$F P C$ is taken from column $\mathrm{E}$

$A D I$ is taken from column $\mathrm{C}$

$S E M_{F P C}$ is taken form column $\mathrm{F}$

$\mathrm{J} \quad$ not used

$\mathrm{K} \quad$ Mean value of EDPY for the given food group and gender, which is calculated from the survey data in the Survey data worksheet as described above.

L Standard deviation of EDPY for the given food group and gender, which is calculated from the survey data in the Survey data worksheet as described above.

M Number of valid EDPY cells (count) for the given food group and gender, which is calculated from the survey data in the Survey data worksheet as described above.

$\mathrm{N} \quad$ Standard error of the mean EDPY for the given food group and gender, which is calculated from the survey data in the Survey data worksheet as described above.

O Percent of the Amargosa Valley population for males $(P M)$ and females $(P F)$ from the 2000 Census data (Bureau of the Census (2002 [DIRS 159728]) for age groups 18 and over.

P not used

Q Mean consumption rate of locally produced food calculated using Equation 6.4-2:

$$
U_{i}=\overline{E D P Y}_{i, m} C A D I_{i, m} P M+\overline{E D P Y}_{i, f} C A D I_{i, f} P F
$$

where: $E D P Y_{m}$ and $E D P Y_{f}$ are taken from column $\mathrm{K}$

$C A D I_{m}$ and $C A D I_{f}$ are taken from column $\mathrm{H}$

$P M$ and $P F$ are taken from column $\mathrm{O}$

$\mathrm{R} \quad$ Partial results for calculation of standard error of the mean consumption rate of locally produced food (Equation 6.4-4), representing the "male" and "female" contribution to the standard error, i.e., the terms that appear in the parentheses before they are multiplied by $(\mathrm{PM})^{2}$ and $(\mathrm{PF})^{2}$ respectively.

$$
\begin{gathered}
S E M_{U_{i}}^{2}=\left(\left(C A D I_{i, m}\right)^{2}\left(S E M_{\overline{E D P Y}_{i, m}}\right)^{2}+\left(\overline{E D P Y}_{i, m}\right)^{2}\left(S E M_{C A D I_{i, m}}\right)^{2}\right)(P M)^{2}+ \\
\left(\left(C A D I_{i, f}\right)^{2}\left(S E M_{\overline{E D P Y}_{i, f}}\right)^{2}+\left(\overline{E D P Y}_{i, f}\right)^{2}\left(S E M_{C A D I_{i, f}}\right)^{2}\right)(P F)^{2}
\end{gathered}
$$

where: $C A D I_{m}$ and $C A D I_{f}$ are taken from column $\mathrm{H}$ $E D P Y_{m}$ and $E D P Y_{f}$ are taken from column $\mathrm{K}$ $S E M_{C A D I m}$ and $S E M_{C A D I f}$ are taken from column I

$S E M_{E D P Y} m$ and $S E M_{E D P Y} f$ are taken from column $\mathrm{N}$

$\mathrm{S}$ In this column calculation of the standard error of the mean is completed by multiplying the values from column $\mathrm{R}$ for males and females by $(P M)^{2}$ an $(P F)^{2}$ (column O), respectively, adding the results, taking the square root of the sum and dividing it by 1,000 to convert the value from grams to kilograms.

T not used 
$\underline{\text { Column }}$

U Mean consumption rate of locally produced food for the biosphere model food types (the regional survey food groups were combines as explained in Section 6.4.2). The values are calculated by either copying the content of cells in column $\mathrm{R}$, if no grouping is involved, or adding the values in column $\mathrm{R}$ if the biosphere model food types include more than one regional survey food group.

$\mathrm{V} \quad$ Standard error of the mean consumption rate for the biosphere model food types. It is calculated by either copying the content of cells in column $\mathrm{S}$, if no grouping is involved, or taking the square root of the squared values in column $\mathrm{S}$ if the biosphere model food types include more than one regional survey food group.

W not used 


\section{APPENDIX B}

CALCULATION OF INHALATION DOSE CONVERSION FACTOR RATIOS FOR DIFFERENT SIZE PARTICLES 


\section{CALCULATION OF INHALATION DOSE CONVERSION FACTOR RATIOS FOR DIFFERENT SIZE PARTICLES}

This appendix explains the spreadsheet calculations of inhalation dose conversion factors (DCF) ratios for particles with the activity median aerodynamic diameter (AMAD) in the range from 0.1 to $100 \mu \mathrm{m}$. The calculations were done using standard function of Microsoft Excel 97 SR-2. The calculation method is described in Section 6.5.5.2. The calculations were done in the Excel workbook named Inhalation of large particles.xls. The file is in Appendix C. The workbook consists of 29 worksheets. The first 27 worksheets contain calculations of the inhalation DCF ratio for individual primary radionuclides of interest (except $\mathrm{C}-14$, which is considered to be present in the atmosphere in gaseous form). The names of the worksheets are the same as the radionuclide symbols; for example, the worksheet named Cl-36 contains calculations of inhalation DCF ratios for ${ }^{36} \mathrm{Cl}$. The 28th worksheet, named Summary, contains the summary of the DCF ratios (presented in the main body of the report in Table 6-27 and their graphical representation (Figure 6-13 in the report)..

The last worksheet, named Np-237(2), contains an example of formulas used to calculate inhalation DCF ratios. The DCF ratios are calculated as follows.

First, the deposition probabilities for particles of $0.1,0.2,0.5,1.0,2,5,1020$, and $100 \mu \mathrm{m}$ in the three regions (naso-pharyngeal, tracheo-bronchial, and pulmonary, of respiratory tract are read from Figure 5.1 in ICRP Publication 30 (ICRP 1979 [DIRS 110386]). These probabilities, denoted as $\mathrm{D}(0.1)$, $\mathrm{D}(0.2)$, and so on, are listed in rows 5 through 7, and columns A through I. In rows 10 through 12, columns A through I, the ratios of deposition probabilities for particles with a given AMAD and particles with AMAD $=1 \mu \mathrm{m}$ are calculated.

In the next step, for every organ listed for a given radionuclide, fractions of dose originating in the naso-pharyngeal, tracheo-bronchial, and pulmonary regions are read from the tables given in ICRP-30 (ICRP 1978 [DIRS 101076], pp. 84-85, 192-193, 231-232, 236-237, 289-290, 318, 322-323, 333-334, 356-357, 362, 364-365, 371, 378, 410-411, 414-415, 418-419, 424-425, 456, 466-467; ICRP 1981 [DIRS 153056], pp. 19, 195, 660-661, 739; ICRP 1982 [DIRS 153057], pp. 790, 827; ICRP 1982 [DIRS 163147], pp. 158-159). These values are listed in column E under the header with a letter $f$. For every organ, these values are multiplied by the appropriate deposition probability ratios in the three regions of respiratory tract and added up (e.g., column $G$ for $0.1 \mu \mathrm{m}$ AMAD; column $\mathrm{L}$ for $0.2 \mu \mathrm{m}$ AMAD). The organ DCF for a given AMAD is calculated as the product of the DCF in that organ for $1 \mu \mathrm{m}$ (column $\mathrm{C}$ ) and the sum calculated in the previous step (e.g., column $\mathrm{H}$ for $0.1 \mu \mathrm{m}$ AMAD; column $\mathrm{M}$ for $0.2 \mu \mathrm{m}$ AMAD). The organ DCFs are added to get the CEDE for a given AMAD and divided by the CEDE for $1 \mu \mathrm{m}$ AMAD (e.g., column I for $0.1 \mu \mathrm{m}$ AMAD; column $\mathrm{N}$ for $0.2 \mu \mathrm{m}$ AMAD). 


\section{INTENTIONALLY LEFT BLANK}


APPENDIX C

FILES SUPPORTING THE ANALYSIS AND CD-ROM 


\section{FILES SUPPORTING THE ANALYSIS AND CD-ROM}

The following Excel files were used in this analysis and are provided on the attached CD-ROM.

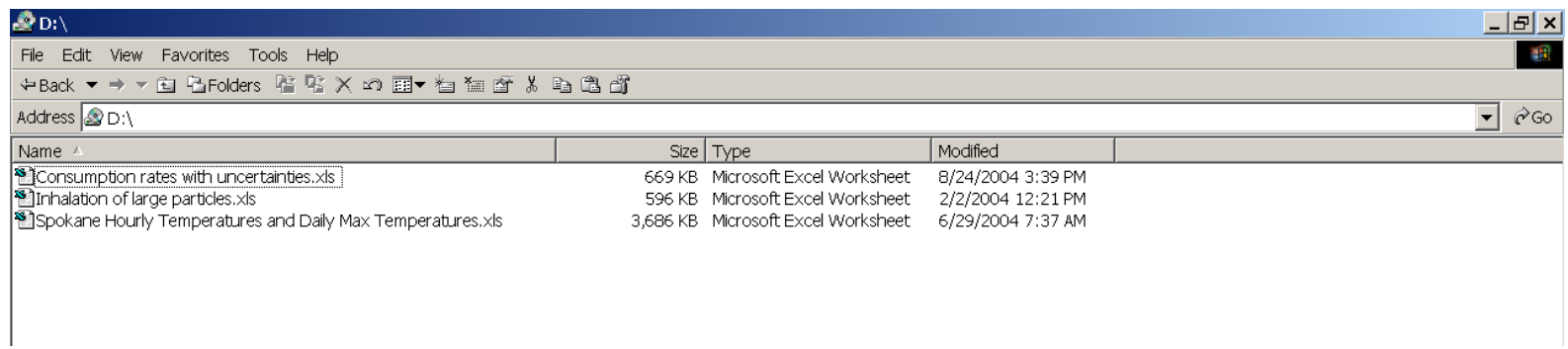

Figure C-1. List of Files Included on CD-ROM 


\section{INTENTIONALLY LEFT BLANK}

